\title{
حو ليةكلية الآداب
}

\section{سنو ية محكمة علمية}

تصدرها

كلية الآداب - جامعة بنى سويف

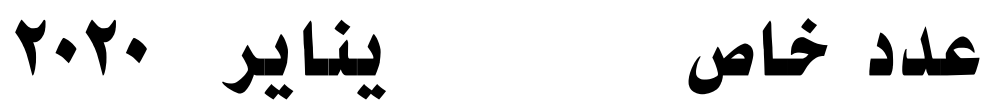




\title{
ISSN. Print: $2314-8160$ ISSN. OnLine: 2314-8179
}

\author{
URL: https://jbsu.journals.ekb.eg/
}

مركز جامعة بني سويف للطباعة والنشر 


\section{هئهة الثمر هر}

رئيس مجلس الإذارة - مارة

عميد الكلية

أ.د. جودة مبرو ك محمد

نائب رئيس مجلس

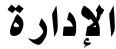

وكيل الكلية لثئون الاراسات العليا

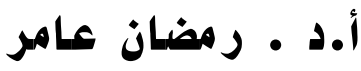

استاذ علم المعلومات المساعد رئيس التحر ير

أ.م.د. مها أحمد إبراهيه

أستاذ علم الأرشيف المساعد نائب رئيس التحرير

أ.م.د. منال سيد محمد

محر رالموقع التحرير

الإلكتر و ني

مدرس مساعد. كلية الآداب

أ.محمد ربيع عبلد الناهر

مصمى الصفحة

مدرس مساعد. كلية الآداب

أ.طله محمد طله حسز

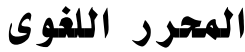

(اللفة العربية)

أ.نورة سيد أبو المجل

المسئول الادارى

أ. منال هحمود

المسئو ل المالى

أ. أحمد الشر قُوى

متابعة مالية

أ. عمر خلف

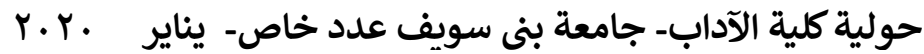




\section{أعضاء هيئة التحر ير:}

أ.د. جبر يل بن حسن المريشي أستاذ علم المعلومات ـ جامعة الملك سعود عضو اً

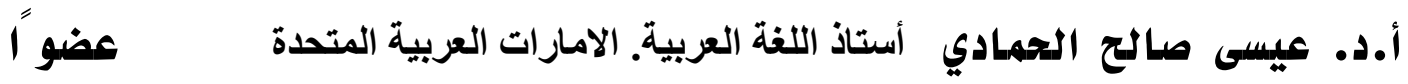
أ.د. مجلدى شفيق السيد صقر أستاذ الجغرافية البشرية جامعة المنصورة عضو اً

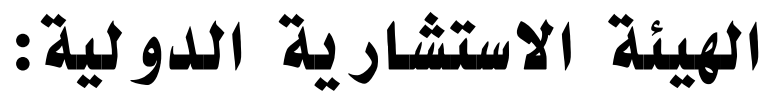

أ.د. ذجاح قبلاز حمد القبلاز "استاذ المكتبات وإلمعومات. قسم المكتبات والمعلومات " كلية الآداب . جامعة الأميرة نورة بنت عبد الرحمن. المملكة العربية السعودية ل أ.د. شر يف الدين بن دوبة "أستاذ الفلسفة.كلية العلوم الاجتماعية والإنسانية. جامعة

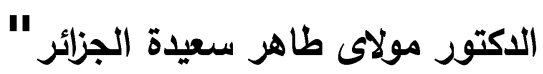
أ.د. عبيل سرور العتيبي "أستاذ الجغرافيا الاقتصادية و رئيس قسم الجغرافيا بكلية "العلوم الاجتماعية .جامعة الكويت

أ.د. محمد بلعباسي "أستاذ الأدب العديث والمعاصر .جامعة حسيبة بن بوعلى فى الثلف الجزائر

أ.د. إبراهيه بز عبلد الله بن عبدالرحمز الزعيبر "أستاذ الإدارة التربوية

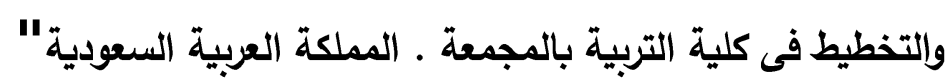
أ.د. هند بنت عقيل بن محمد الميزر "أستاذ الخدمة الاجتماعية الإكلينيكية بقسم

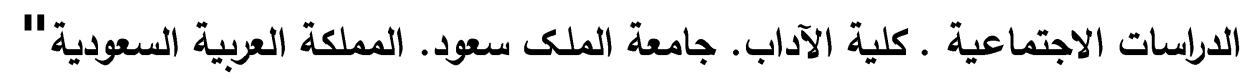
أ.د. محمد ملياذى "أستاذ النقد الحديث والمعاصر بجامعة وهران" ل 
أ.د.فوزية محمد على مر اد "استاذ الدراسات الفلسفية ـ كلية الآداب ـ الجامعة الأسمرية

$$
\text { "الإسلامية أدهو }
$$

أ.د. عبد الحسين رزوقى مجيد الجبورى "أستاذ علم النفس التربوى ـ قسم العلوم

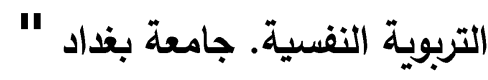

أ.د.الهادى بووشمة "أستاذ مختص فى علم الاجتماع قسم علم الاجتماع بجامعة سيدى "

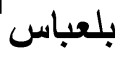

أ.د. بلخيرى مر اد "أستاذ علم الاجتماع. جامعة قسنطينة r ، عبد الحميد مهرى" أ.د. شناف خلديجة "استاذ علم الاجتماع جامعة عبد الحميد مهرى قسنطينة r" أ.د. ججيقة أحمد محمد قزوي "أستاذ علم النفس . جامعة الجزائر ץ" أ.د. جمال عيسى شليحى بلبكاى "أستاذ علم النفس .جامعة منتورى قسنطينة،الجزائر" أ.د. و ليد عبد العزيز عمار بخوش "أستاذ علم النفس . جامعة العربى بن مقيدى بأم البواقى (الجزائر)) أ.د. مها ابر اهيه ال كلثم " أستاذ المناهج وطرق التدريس. فلسفة التربية كلية التربية

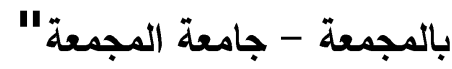

أ.د.على عبد كنو على "أستاذ فلسفة علوم قرآن. كلية العلوم الاسلامية ـ جامعة ديالى" أ.د. كر يمة خدو سي "أستاذ علم النفس المعرفى جامعة البويرة" 


\section{الهيئة الاستشارية الهملية:}

أ.د. أسامة السيد محمود على "أستاذ المكتبات و المعلومات. قسم المكتبات

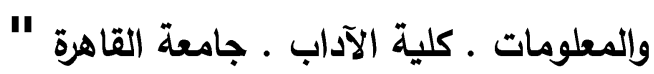

أ.د. إيناس حسيز صادق احمد "أستاذ المكتبات و المطومات. قسم المكتبات والمعلومات . كلية الآداب . جامعة حلوان مينان

أ.د. رباح فوزى محمد عبد اللطيف "أستاذ المكتبات والمعومات بكلية الارسات

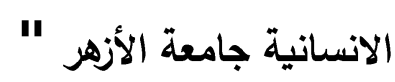

أ.د. سمير سعد حامد خطاب "أستاذ علم النفس الاجتماعى ورئيس قسم علم النفس كلية الآداب. جامعة جنوب الوادى"

أ.د. محمود أحمد محمد خيال "استاذ علم النفس بكلية الاداب جامعة المنوفيه " أ.د. خالد عبد الرازق السيد النجار "أستاذ علم النفس المساعد. كلية الآداب ـ

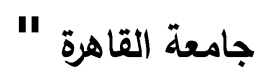

أ.د. عائشة محمود محمد عبد العال "أستاذ التاريخ القديم والآثارو رئيس قسم

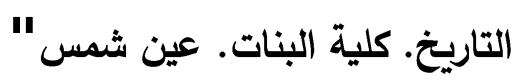

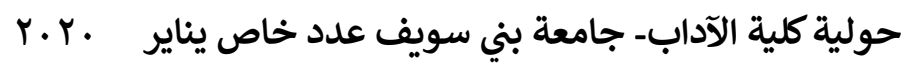




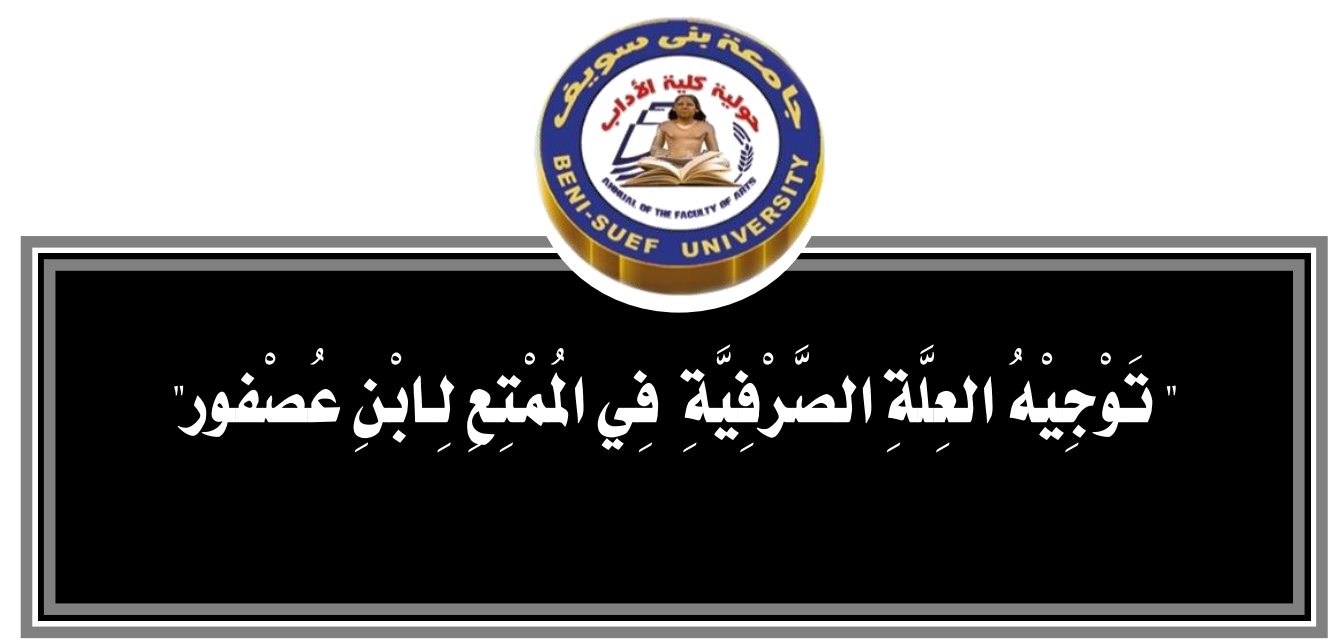

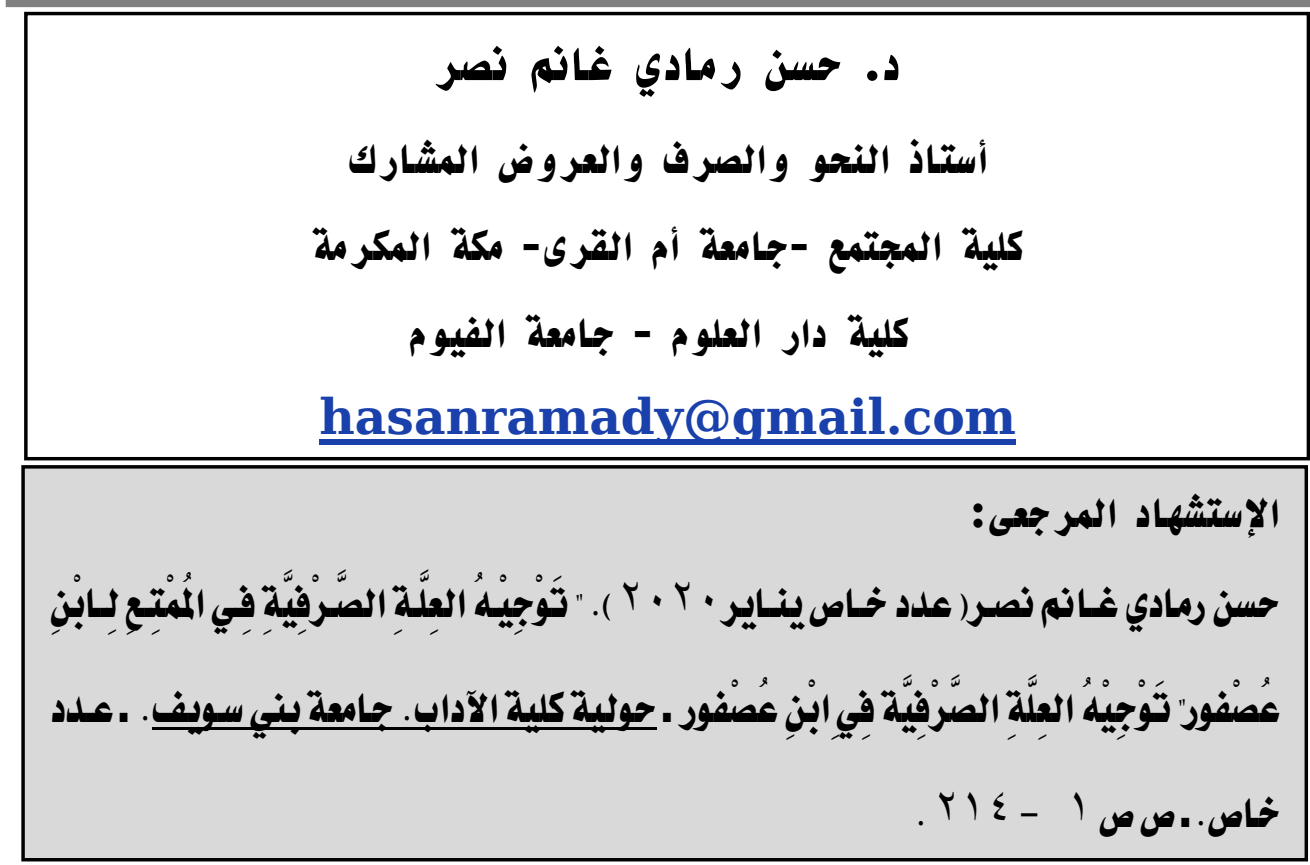

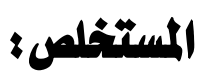

محور البحث( توجيه العلـة الصـرفية في الممتع لابن عصفور) : اثنتا عثرة علـة ،فمسائله متتوعة، ومادتها العلمية ضخمة ، إضـافة إلى أنها من أعظم كتبه خاصـة، ومن أبرز المصنفات العربية عامة، والمكانة التي يحظى بها هذا العالم في علم الصرف. ويهدف البحث إلى: جمع ما تناثر من علل في مؤلف واحد بدقة وإحكام واستقصاء وإحاطة، والاهتمـام بالعلل التي وردت في الممتع وتوجيهها حرصـا على تمكين القاعدة ، 


\section{د. حسن رمادي غانم نصر}

وإحكام الأحكام لتمتد العربية متأصلة القواعد متينة الأحكام ، والاهتمام بالمسائل الكلية والجزئية واستيفاء القول فيها ليتسم البحث بالثمول وجمع العلاقات بين الأثباه والنظائر، في ترتيب واختصار .

وتبدو أهمية البحث من خلال متابعة الحكم من ابن عصفور ، ثم بيان ما يتعلق

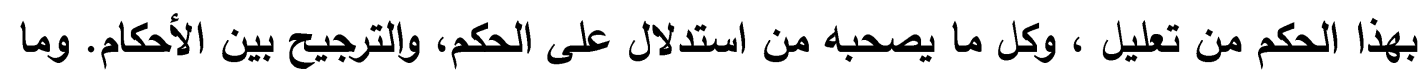
شجعني على دراسة هذا الموضوع أني وجدت أكثر من كتاب في التعليل النحوي. وكتاب المتع من أمثل كتب الصرف المطولة حتى قلَّ أن يخلو من مسائله كتاب

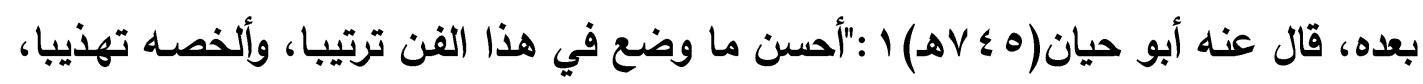

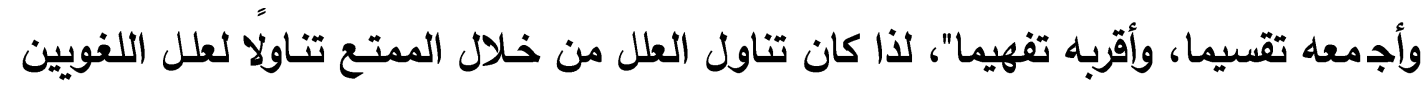
حتى القرن الرابع الهجزي.

وسيسلك البحث المنهج الاستقرائي التحليلي، من حيث استقراء وتحليل التعليل

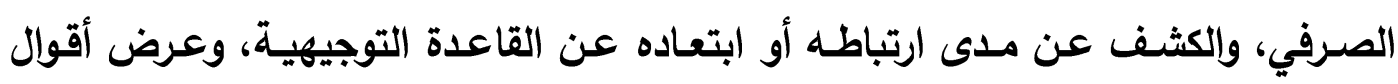

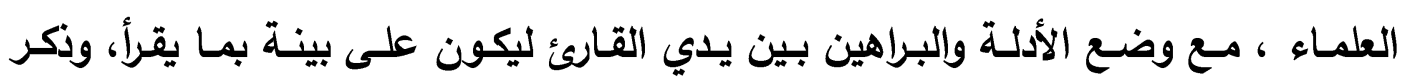

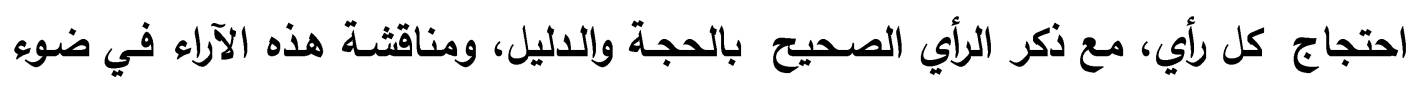

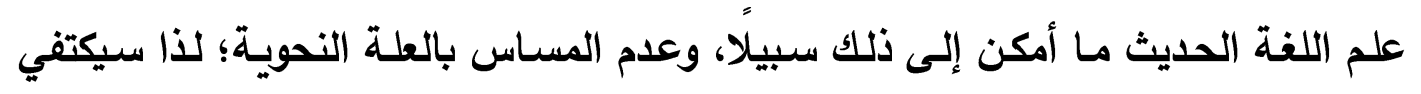

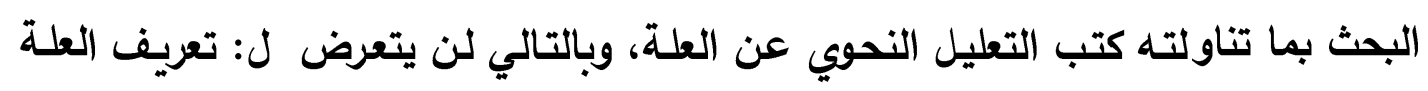

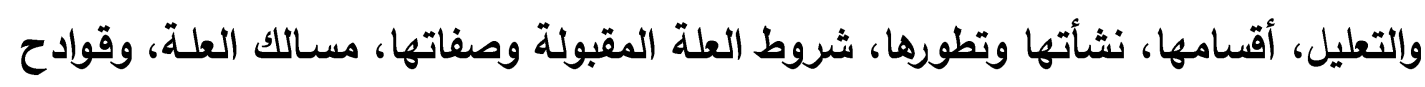
العلة.

الكلمات الدالة : العلة الصرفية - ابن عصفور - كتاب المتع- التعليل النحوى ')|أبو حيان: انظر تفسير البحر المحيط/ا؟.

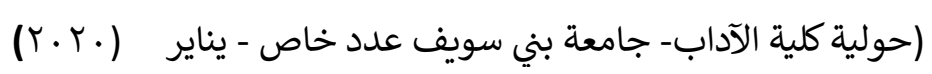




\section{Abstract:}

This paper deals with twelve types of morphological conditioning addressed by the renowned linguist Ibn Osfour in his book The Enjoyable, which is one of the greatest, richest and largest books written by the aforementioned author. The main objective of the paper's author is to bring together as many types of morphological conditioning as possible, so that they can be easily accessible to readers. The paper particularly focuses on the examples handled by Ibn Osfour, which is done with a view to highlighting the rules underlying these examples through identifying consistencies and similarities in a way that is both brief and orderly.

The importance of this paper consists in the fact that it focuses on the way Ibn Osfour passes judgments on different morphological structures and then states the reasons why he deals with these structures the way he does. Furthermore, the paper expounds on the different opinions concerning these structures, and then gives reasons why one of these opinions is to be regarded as the right one. I was encouraged to write this paper by the fact that I have found that this kind of grammatical reasoning, so to speak, was tackled in various sources.

Ibn Osfour's The Enjoyable is one of the most reputable and reliable books on Arabic morphology; one can rarely, if ever, find a book on Arabic morphology whose author does not fall back on The Enjoyable. Abu Hayyan (745 H) said about it: ' The Enjoyable is the best book that was written on morphology as far as organization, conciseness and readability are concerned'. This is why morphologists

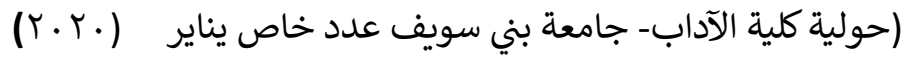




\section{د. حسن رمادي غانم نصر}

entirely depended on it when tackling morphological processes till the fourth Hijri century.

As for the current paper, it uses the inductive, analytical approach in analyzing the types of morphological conditioning in question and indicating their relation to the rule, and referring to the different opinions of the Arab linguists in this respect, meanwhile stating linguistic evidence that would help the reader fully understand what $\mathrm{s} / \mathrm{he}$ is reading. Besides, the various opinions concerning the types of morphological conditioning are discussed in the light of modern linguistic theory, and the correct opinion is highlighted and supported through examples. It is worth mentioning that the current paper only deals with what is mentioned in resources about morphological conditioning, and, therefore, will not deal with conceptual or historical issues pertaining to morphological conditioning, nor will it approach morphological conditioning prescriptively by dealing, for instance, with 'optimal' conditioning or unacceptable conditioning, so to speak.

Keywords: morphology - morphology- Ibn Osfour's morphological structures

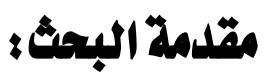

الحمد الله رب العالمين، والصلاة والسلام على أشرف الأنبياء والمرسلين سيدنا ونبينا

محمد وعلى آله وصحبه أجمعين، وبعد:

فمحور البحث : اثنتا عشرة علـة في "الممتـع في التصريف" لابن عصفور (أبو الحسن ت 979 7هـ) ، فمسائل متنوعة، ومادتها العلمية ضخمة ، إضـافة إلى أنه من أعظم 
كتبه خاصة، ومن أبرز المصنفات العربية عامـة، والمكانـة التي يحظى بها هذا العالم في علم الصرف.

\section{أهداث البهتش:}

1-جمع ما تناثر من علل في مؤلف وإحد بلدقة وإحكام وإستقصاء وإحاطة.

ץ - الاهتمـام بالعلل التي وردت في الممتع وتوجيهها حرصـا على تمكين القاعدة ، وإحكام الأحكام لتمتد العربية متأصلة القواعد متينة الأحكام. ץ-الاهتمـام بالمسـائل الكلية والجزئية واستيفاء القول فيها ليتسم البحث بالثمول وجمع العلاقات بين الأشباه والنظائر، في ترتيب واختصار.

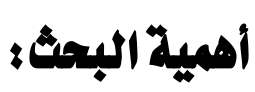

تبدو أهمية البحث من خلال متابعة الحكم من ابن عصفور ، ثم بيان ما يتعلق بهذا الحكم من تعليل ، وكل مـا يصحبه من استدلال على الحكم، والترجيح بين الأحكام. ومـا شجني على دراسـة هذا الموضوع أني وجدت أكثر من كتاب في التعليل النحوي، منها: العلة النحوية -نثأتها وتطورها ، د. مازن المبارك ، ونظرية التعليل في النحو العربي بين القدماء والمحثثين ،د. حسن خميس سعيد الملخ، والتعليل النحوي في الارس اللغوي القديم والحديث، خالد بن سليمان بن مهنا الكندي، وغيرهم' .

')هناك مؤلفات قديمة في العلة، منها: الزجاجي: الإيضـاح في علل النحو، ابن الوراق(1 ^זهـ): علل النحو، ابن جني: علل

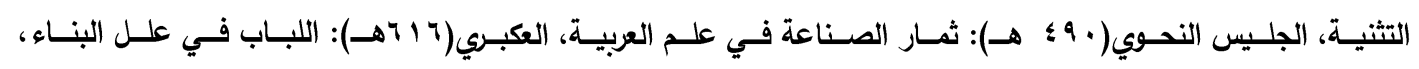

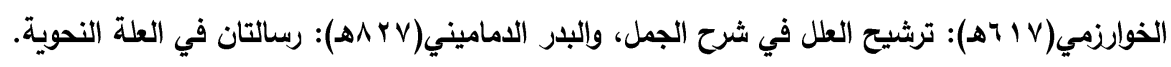




\section{لماذا كتاب المقتع في التصريف لابن مصفور؛}

كتاب المتع من أمثل كتب الصرف المطولية حتى قل أن يخلو من مسائله كتاب

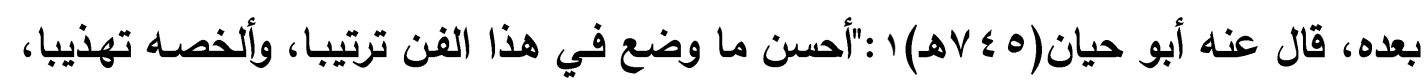

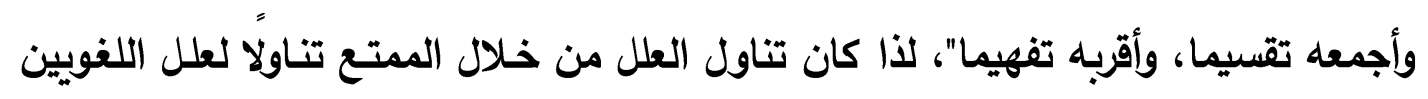
حتى القرن الرابع الهجري ،وذلك للأسباب التالية: بسط ابن عصفور مسائل التصريف فيه بسطًا مسهبا مدعوما بالتعليل وإحجاج،

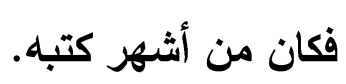

في خطبة كتابه لا يدَّعي أنه أبدع في علوم التصريف شيئًا جديداً ، وإنما يقر أنه أخضع جهود أسلافه في هذا العلم حتى القرن الرابع لضرب من التهذيب والتبويب ليقربها

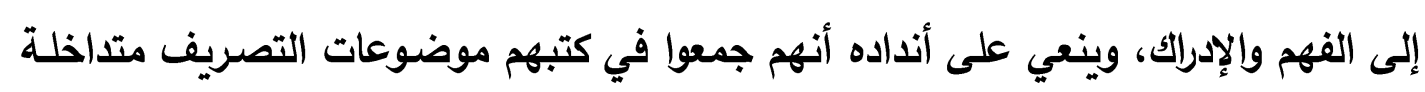

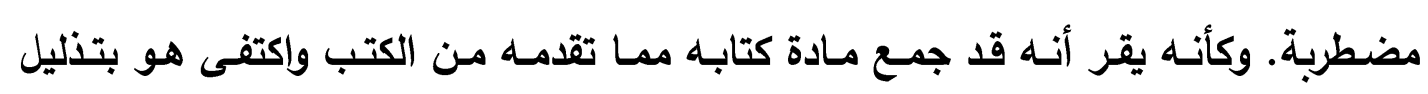
الموضوعات وتهذيب ألفاظها وتقريبها.

فدائما يقول: قال سيبويه( • 1 اهـ)، وحكى الكسائي(9 ا اهـ)، وحكى أبو عمر

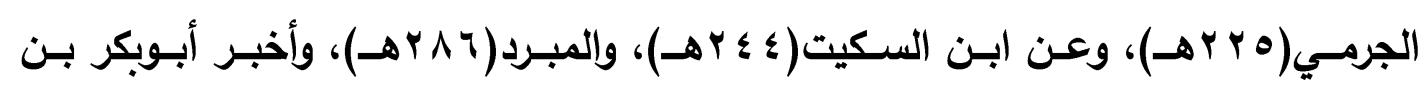

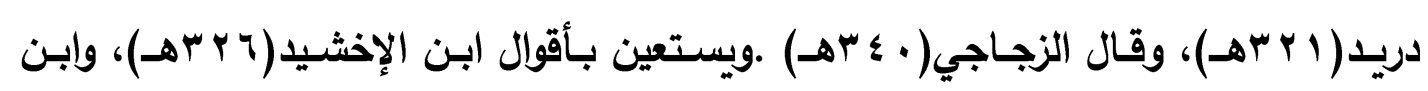

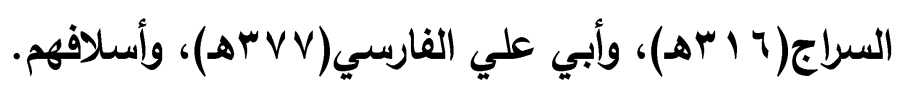

'أبو حيان: انظر تفسير البحر الححيط//7.

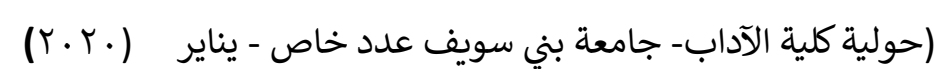


ا- لــ يلتزم مـذهب البصـرة أو الكوفـة أو بغداد، إنمـا اتبع مـهـج المحققين مـن العلماء معتمدا على الاختيار المدعوم بالدليل؛ لذا كان موقفه من علمـاء التصريف موقف المختار المميز الذي لا يـتبط بآثارهم إلا في حدود مـا يلائم منهجه بـليل أنه أخذ عن من البصـريين وخـالفهم ، وكــلك كـان موقفـه مـن الكـوفيين والبغـاديين، وإن كانـت مخالفتـه للكوفيين أوسع.

r - في موقفه من البصريين والكوفيين والبغداديين لا يتخطى القرن الرابع، إذ يقف

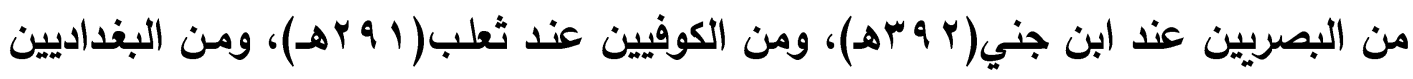
عند القالي( اه ب هـ). أما من خلف بعد هؤلاء من علماء تلك المدارس الثلاث فلا ترى لـه في الممتع أخذًا عنهم وموافقة لهم أو مخالفة. r- اعتماده الجدل والاحتجاج حتى يستوفي جميع جوانب الموضوع، فربما يعرض للمسألة الواحدة مذهبين، ويحتج لكل منهما، ثم يرجح أحدهما على الآخر بحجاجه المنطقي اللغوي، منثورا في طياته فيض من ألوان السماع والقياس. ع - أما أسلوبهـ في معالجة العلل فيجمع بين الوضوح والبساطة تارة والغموض تارة أخرى، مما دفني لمتابعة المادة العلمية في مظانها لفك ما استغلق وإيضاح ما أبهرم مثرج البمجثة ا- سيسلك البحث المنهج الاستقرائي التحليلي، من حيث استقراء وتحليل التعليل الصرفي، والكشف عن مدى ارتباطه أو ابتعاده عن القاعدة التوجيهية. 


\section{د. حسن رمادي غانم نصر}

r- لن أتعرض للحديث عن ابن عصفور فيكفي ما تناوله السابقون عن حياته ،

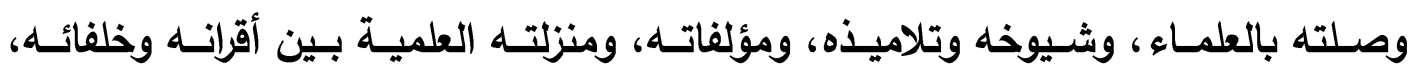

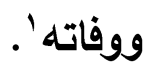

فأردت أن أجمع العلل الصرفية في كتاب يجمع شتاتها من بطون الكتب هنا وهناك، ثم توزيعها ،وتحليلها ،والإحاطة بالمشكلات والآراء المتثابهة والمتخالفة لوضعها في وحدة منهجيـة متسقة منتظمة، ولا شكَّ أن البحث استتد في سبيل ذلك إلى المصادر القديمسة والحديثة، فالمصادر القديمة تورد شواهد وأمثلـة لها كمـا هو واضـح في كتاب سيبويه، والمقتضب ، وكتب أبي علي الفارسي، وابن جني، وكل من جاء بعدهم مرددا كلامهم

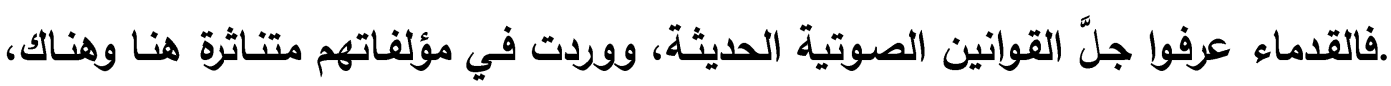
ومعظم الدراسات الحديثة تقوم على المادة الأساسية عند القدماء. ولا فضل لي سوى جمع وترتيب العلل ، وتحليل أمثلتها، وإخراجها بمـا يتلاءم مـع طبيعة الموضوع.

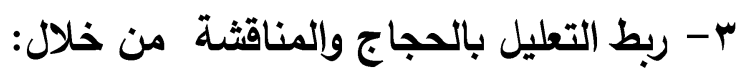
- عرض أقوال العلمـاء ، مـع وضع الأدلة والبراهين بين يدي القارئ ليكون على بينة بما يقرأ. - ذكر احتجاج كل رأي ، مع ذكر الرأي الصحيح بالحجة والدليل.

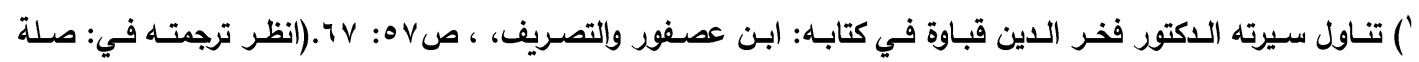

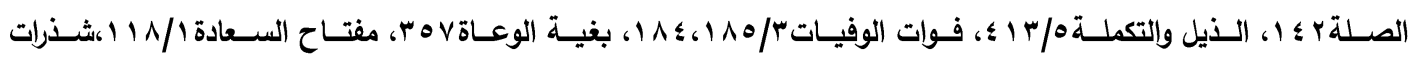

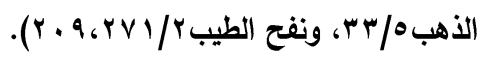

(حولية كلية الآداب- جامعة بني سويف عدد خاص - يناير (·. ) 
- مناقثة هذه الآراء في ضوء علم اللغة الحديث ما أمكن إلى ذلك سبيلا. ع- لم يستثه البحث بالأمثلة أو مـا تسمى التمارين العملية التي لا وجود لها في اللغة العربية إلا في المكان الذي يوجب تثبيت قاعدة أو رأي. ه- عدم المسـاس بالعلـة النحويـة؛ لذا سيكتفي البحث بــا تناولتهه كتب التعليل النحوي عن العــة ، وبالتـالي لن يتعرض ل : تعريـف العلـة والتعليل، أقسـامها، نثـأتها وتطورها، شروط العلة المقبولة وصفاتها، مسالك العلة، وقوادح العلة.

\section{الدراسيات السبابقة}

مـن الدراسـات السـابقة ذات الصـلة بالعـلة الصـرفية: "قواعد التوجيهه في الصـرف العببي" ،رسالة دكتوراه، د. عصام ندا، كلية دار العلوم جامعة الفيوم ؟r. . بم.تناول فيها: في التمهيد: تعريف القاعدة التوجيهية، المقارنـة بين قواعد التوجيه في الصرف العربي والقواعد الصرفية، ونشأة قواعد التوجيه وتطورها في التراث.

البـاب الأول: قواعد التوجيـه المبنويـة ، في ثلاثـة فصـول، الأول: قواعد توجيـه استثقال البنية، الثاني: قواعد توجيه نفي اجتماع شيئين في البنية، والثالث: قواعد توجيه اختصاص البنية.

البـاب الثاني: قواعد التوجيسه الاستـلالية، وقســهـ ثلاثـة فصـول: الأول: قواعد التوجيه الاستدلالية التحويلية، تناول فيه: قواعد توجيه الأصل والفرع، قواعد توجيه الرد 
إلى الأصل، وقواعد توجيه العدول عن الأصل. والفصل الثاني: قواعد التوجيه الاستدلالية الأولوية. والثالث: قواعد توجيه استدلالية مختلفة.

الباب الثالث: قواعد التوجيه والدرس الصرفي، ينقسم إلى خمسة فصول : العلاقة بين قواعد التوجيه وأصول التصريف، العلاقة بين قواعد التوجيه والتعليل الصرفي، والعلاقة بين قواعد التوجيه ومسائل الخلاف الصرفي، والعلاقة بين قواعد التوجيه وعلم المنطق، والعلاقة بين قواعد التوجيه وعلمي الفقه والكلام. ويختلف بحثي عن رسالة الدكتور عصام ندا في التالي:

1- البحث خاص بتوجيه العلل الصرفية الواردة في كتاب المتع وعلاقتها بأصول التصريف أو أدلته -السماع ، واستصحاب الحال، والقياس- والعلة التي نثأت وراء هذه الأصول ، وهي علاقة عموم وخصوص، ورسالته تتمثل في القواعد العامـة التي تضبط

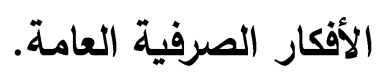
r- البحث يهتم بالناحية التطبيقية -لا النظرية كما فعل هو في رسالته- لاراسة

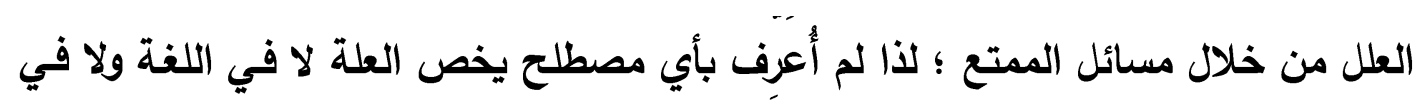
الاصطلاح حتى لا أكرر كلمة واحدة سبقِتُ إليها. وبالتالي فالموضوع جادّ ويحتاج إلى دراسة ،فلم يسبق بدراسـة مستقلة تحمل في طياتها دلائل التفسير للظواهر الصرفية. 


\section{وقد قسمت بعثي اثثتي عشرة علة' ، هي ؛}

\section{الملة الأولى: المصل (الأونَى )}

المقصود بعلة الحمل(الأَلَحَ): جعل استدلال معين أولى من استدلال صرفي آخر، وهو ما عبَّر عنه الصرفيون بالتالي: - الحمل على الأكثر أولى من الحمل على الأقل. - الحمل على ماله نظير أولى من الحمل على ما ليس له نظير. - حذف ما ليس له معنى أولى من حذف ما لله معنى.

- حمل الثيء على الثيء : أي :إلحاقه بـه وإعطاؤه حكمـه، ويكون ذلك إمـا على اللفظظ ، أو على الموضـع، أو على المعنى. فمـن عـادة العرب أنهم يـؤثرون التجـانس وإلتثابه؛ فلذلك حملوا الفرع على الأصل وردوه إليه ، كما حملوا الأصل على الفرع لإيثارهم تشبيه الأشياء بعضها ببعض.

كذلك حملوا الثيء على نظيره لمشـابهته لـه لفظًا أو معنى أو لفظًا ومعنى ‘، وقد

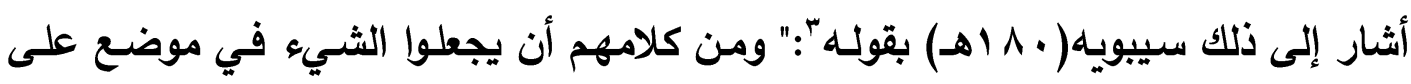

$$
\begin{aligned}
& \text { ') ترتيب علل البحث حسب أهميتها وترابط بعضها ببعض. }
\end{aligned}
$$

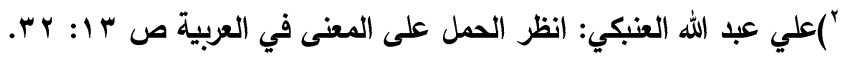

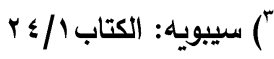




\title{
د. حسن رمادي غانم نصر
}

غير حاله في سائر كلامهر"، وأفرد له ابن جني' فصلًا في "باب شجاعة العربية" المتمثلة في: الحذف، والزيادة، والتقديم والتأخير، والحمل على المعنى، والتحريف. وقال في هذا الفصل":"اعلم أن هذا الثرجّ غور من العببية بعيد، ومذهب نازح فسيح، قد ورد به القرآن وفصيح الكلام منتورا ومنظوما، كتأنيث المذكر، وتذكير المؤنث، وتصور مغنى الواحد في الجماعة، والجماعة في الواحد، وفي حمل الثاني على لفظ قد يكون عليه الأول، أصلّا ذلك اللفظ أو فرعا"، وهو عند ابن هشام" من باب: "ما أعطي الثيء المشبه له في لفظه دون

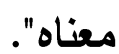

ولِعَّة الحمل عدة صور، هي:

\section{أولًا : العطل على ماله نظير}

هم يحملون الثيء على ضده كما يحملونه على نظيره، و الحمل على ماله نظير أولى من حمله على ما ليس له نظير . ويقصد به :حمل النظير على النظير للشبه اللفظي أو المعنوي أو كليهما، وهو ما أطبق عليه ابن جني: القياس اللفظي، حيث يقول:" واعلم

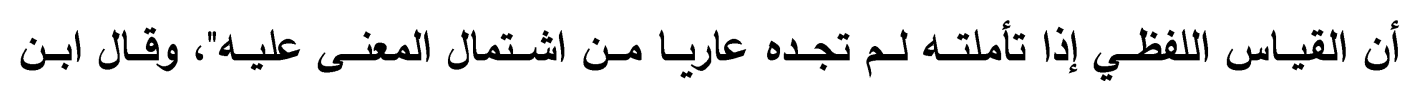

\author{
'باين جني: الخصائص r/. r"ז. \\ | \\ ") الثرج: النوع.

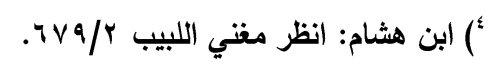


السراج(7 آهـ)' :"وكثيرا ما يعملون الثيء عمل الثيء إذا أثبهه في اللفظ وإن لم يكن

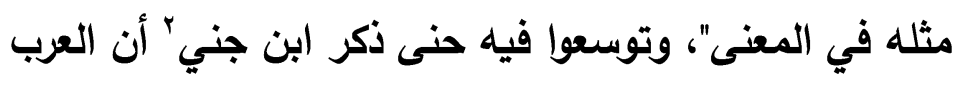
قد تجري الثيء مجرى نقيضه كما تجريه مجرى نظيره.

إن ابن عصفور في استعماله أسلوب الحمل على النظير متأثر من غير شك بثيخه سيبويه المتأثر بثيخه الخليل( • V Vه) الذي اهتم كثيرا بالفقه وعلم الكلام. ومن الحالات التي علل بها ابن عصفور الحمل على ما له نظير ما يأتي:

\section{1}

ذكر أبو الحسن قلب الواو المكسورة غير أول همزة حملًا على "|قائيم" جمع "قوم"،

وهو مذهب الزجاج، حيث يقول":" وأمـا مصائب في جمع مصيبة فكان القياس فيها| مصاوب)على مـا يبين في باب القلب- فإمـا أن يكونوا همزوا الواو المكسورة غير أول شذوذًا فتكون مثل " أقائيم" في جمع " أقوام" وهو مذهب الزجاج، وإمـا أن يكونوا غلطوا

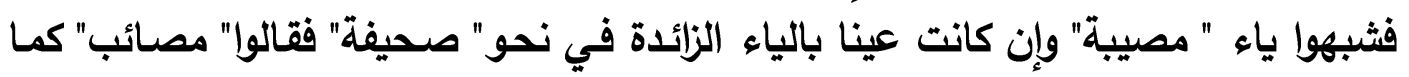
قالوا" صحائف" ، وهو مذهب سييويه. والأول أقيس عندي لأنه قد ثبت له نظير وهو: "

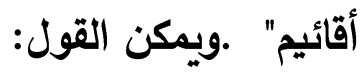

$$
\begin{aligned}
& \text { ') ابن السراج: انظر الأصول في النحو / آه } 9 .
\end{aligned}
$$

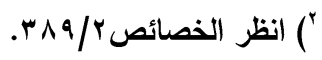

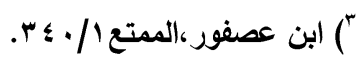




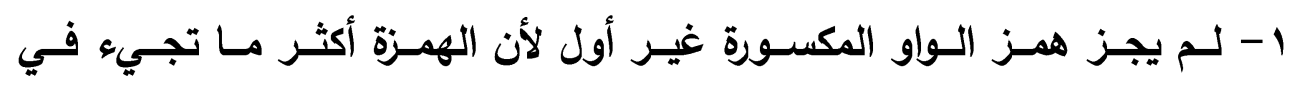

الأطراف(أسود، أحمر، حمراء، صفراء)، وقلتها زائدة حشوا، نحو: شمأل و شأمل.

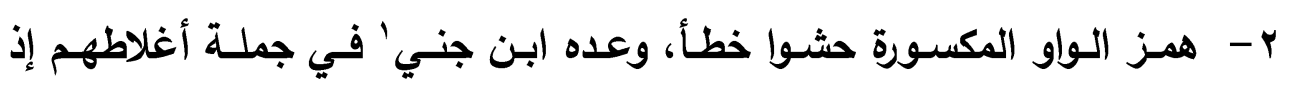

أصل" مصيبة" :مصوبة"، فنقلت كسرة الواو إلى الصاد، فسكنت الواو مفردة بعد

كسرة فانقلبت ياء :وقياس جمعه" :مصاوب.".

ץ- تخريج همز الواو المكسورة غير أول هنا حمـلا على همز الواو المضمومة،

نحو "أدؤر" لأن المكسورة ليست في ثقل المضمومة، والهمز في الطرف أسوغ منه في الحشو. فلما كانت المضمومة أثقل جاز قلبها في كل موضح، ولم يجز قلب المكسورة في الحشو لأن الحشو أقوى من الأول.

צ- زعم أبو الحسن أن العرب شذت في كلمة واحدة هي "مصائب" فهمزت فيها العين، وقد فاته أنه ذكر شذوذهم في "أقائيم" جمع: أقوام، وأن هذا الثذوذ جاء أيضًا في "منائر" جمع: منارة، و"مسائل" جمع: مسيل، و "معائش" جمع :معيشة". ه- الهمز هنا خارج عن القياس.

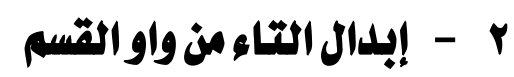

ذكر أبو الحسن إبدال التاء من واو القسم ، رافضًا أن تكون أبدلت من الباء ،

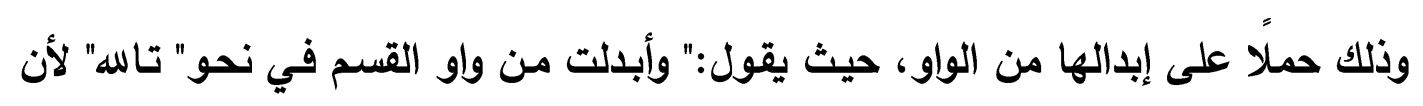

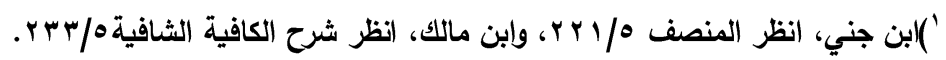

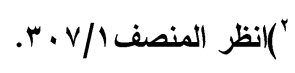

(حولية كلية الآداب- جامعة بني سويف عدد خاص - يناير (·. ) 
الأصل الباء بدليل أنك إذا جررت المضمر أتيت بالباء فقلت "به" و "بك" لأن المضمرات ترد الأشياء إلى أصولها، ثم أبدلت الواو من الباء، ثم أبدلت التاء من الواو. فإن قال قائل: ولعلها أبـلت من الباء. فالجواب أن إبدال التاء من الواو قد ثبت ولم يثبت إبدالها من الباء، فكان الحمل على مـا لـه نظيز أولى. وأيضًا فِإن العرب لما لم تجر بها إلا اسم الله تعالى دلَّ ذلك على أنها بدل من بدل لأن العرب تخص البذل من البدل بثيء بعينه"' . ويمكن القول إن التاء أبدلت من واو القسم لا من الباء حملًا على إبدالها من الواو

فاء: ، وهو إبدال التاء من كل واو وقعت فاء في افتعل وما تصرف منه، نحو :اتعد واتتزن، ويتعد ويتزن ومتّعد ومتزن والأصل: اوتزن ويوتزن وموتزن و اوتعد ... ،فقلبوا الواو تاء

وأدغموها في تاء الافتعال ·

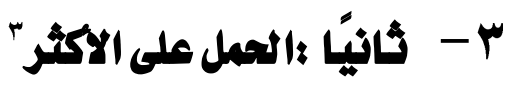

يعدُّ مبدأ القياس على الكثرة من المبادئ المهمة في الدرس الصرفي، وهو قربب من مفهوم المطرد والغلب،وهو أولى من الحمل على الأقل ، وقد علل بـه ابن عصفور مـا يأتي:

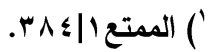

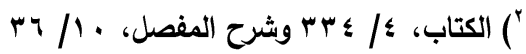

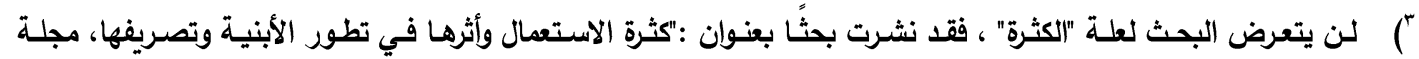

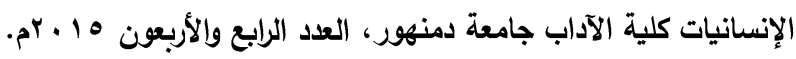




\section{1}

ذهب ابن عصفور إلى الحمل على الأكثر فيما انقلبت عنه ألف "واو" ،حيث يقول:"

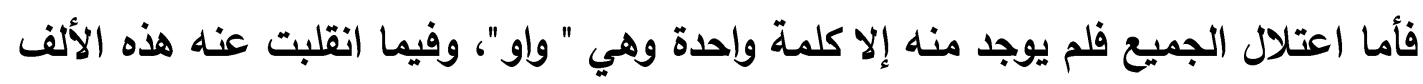

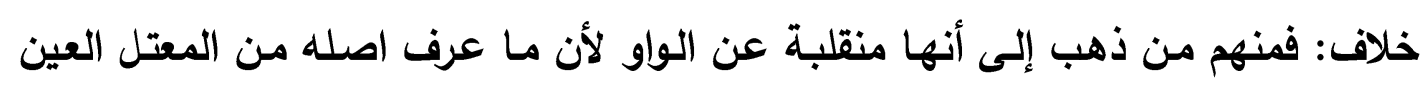

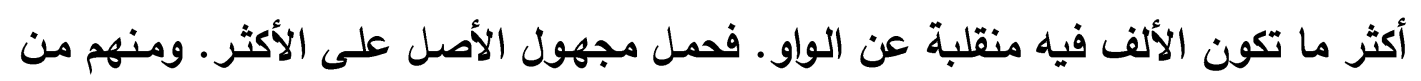
ذهب إلى أنها منقلبة عن ياء ـ وإلى هذا القول كان يذهب أبو على لعلي.

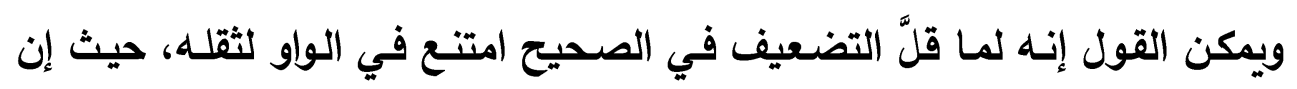

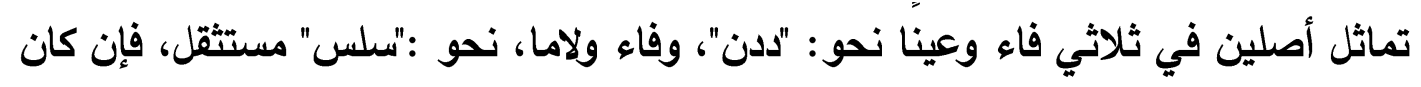

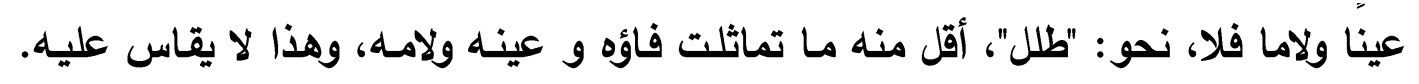

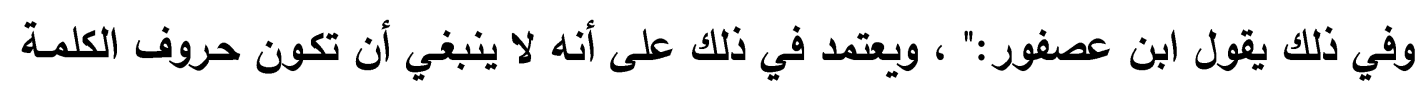

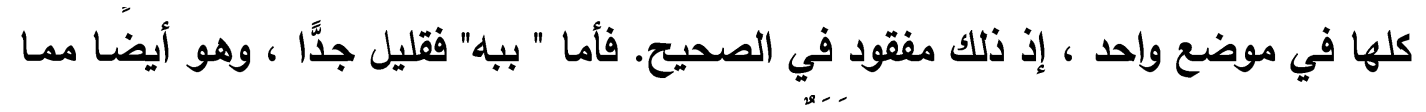

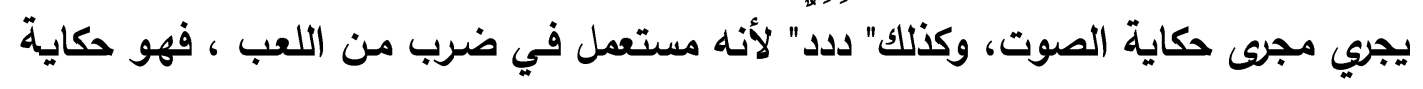

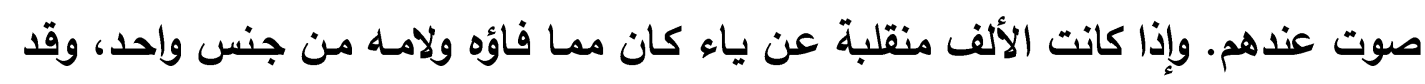

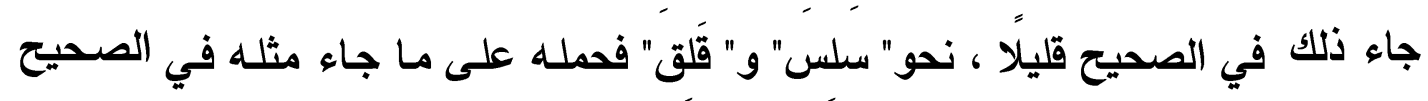
أولى.

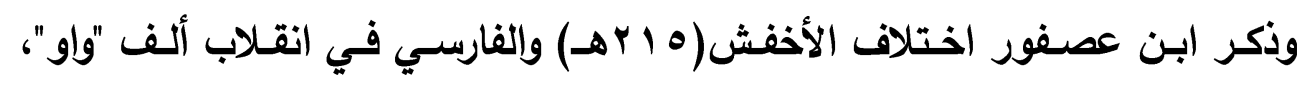

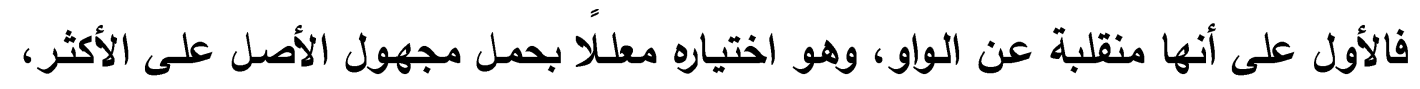

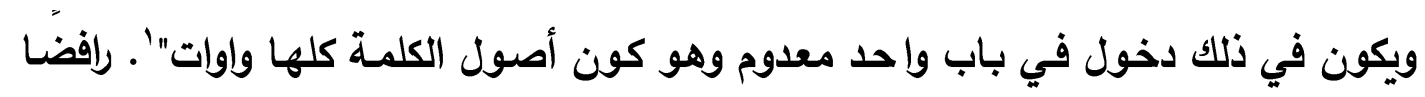

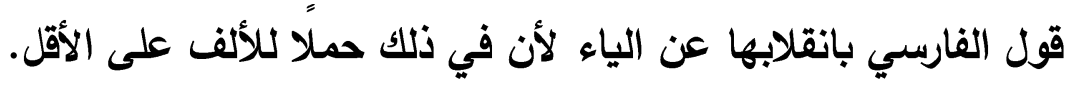




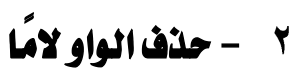

مما يمتنع فيه الإعلال فلا تحذف الواو إن كان فاء في اسم، ذهب ابن عصفور إلى أن المحذوف من "ثبة" و "ظبة" الواو لاما لا فاء حملًا على الأكثر، متفقًا مـع الأخفش، حيث يقول:" حذفت الواو لاما في أثياء صالحة........ وحذفتْ من "ثُبة" اسم الجماعة من

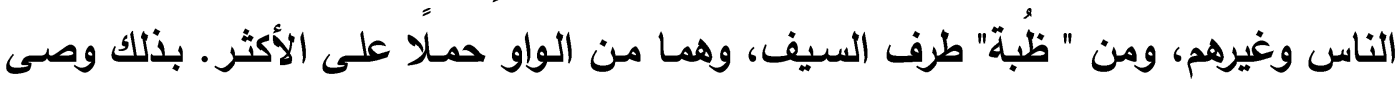

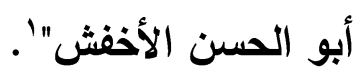

ويمكـن القـــول إن الفـاء لــم يطــرد حــذفها إلا فــي مصــادر بنــات الــواو، نحو" عدة "و"زَنة "و"جدة " ، وليست" ظبـة "من ذلك، وأوائل تلك المصـادر أيضًا مكسورة، وأول" ظُة "كما ترى مضموم · و"ثبة "المحذوف منها اللام دون الفاء والعين، يدل على ذلك

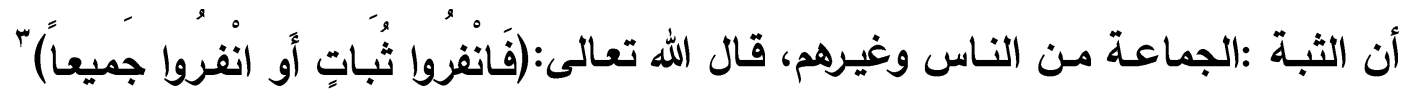
،ف" ثبات "كقولك: جماعات متفرقة، أو اجتمعوا كلكم. فهذا أكثر مما حذفت لامه ياء، فعليه ينبغي أن يكون العمل، وبه أيضًا وصى أبو الحسن؛، فقد ثبت أن أصل" ثبة" "ثبوة." والقول في" ظُبة "أيضًا كالقول في" ثُبة "ولا يجوز أن يكون المحذوف منها فاء ولا عينـا ،بخلاف مذهب الزجاج • في" ثُبة الحوض - "وهي وسطه- أنها من" ثاب المـاء إليها "وأن الكلمـة

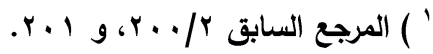

$$
\begin{aligned}
& \text { |rir }
\end{aligned}
$$

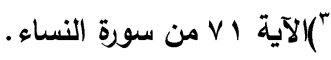

؛) البحث يطلق على ابن عصفور أبا الحسن وهي كنيته، والمقصود هنا : الأخفش.

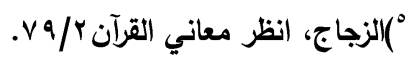




\section{د. حسن رمادي غانم نصر}

محذوفة العين، وقال" :تقول في تصغيرها ثُويبة ."وهذا غير لازم، لأنـا يجوز أن تكون

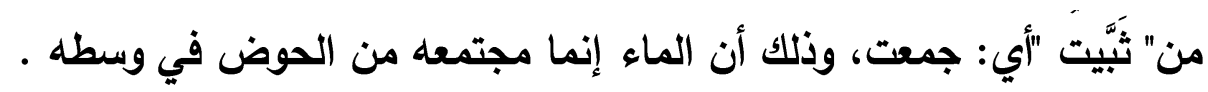

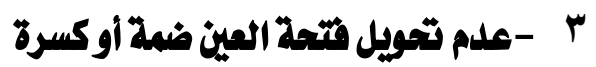

\section{عند قلب الواو الفا في" انفعل" و"|فتعل"}

على الرغم من الحمل إلا أنه ينتج عنه بناء غير موجود، يقول أبو الحسن: "إلا

أنك إذا أسندتهما إلى ضمير متكلم أو مخاطب لم تُحوِل الفتحة التي في العين -إذا كانت

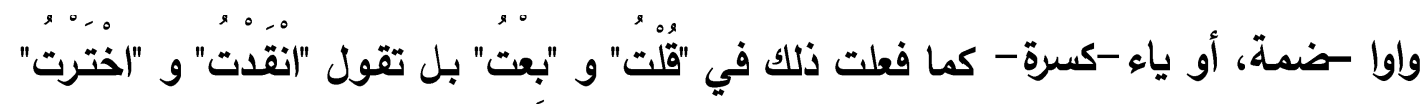
،فتسكن آخر الفعل للضمير، ومـا قبله سـاكن فتحذفه لالتقاء السـاكنين من غير تحويل. وإنما تحول لأنك لو حولت في ذوات الواو حركة العين ضمة لنقلت "انفعلت" و "|فتعلت" إلى " انفَعل" و "|فتعل" وهما بناءان غير موجودين. وكنلك لو حولت في ذوات الياء حركة العين كسرة لنقلتها إلى "انفعل" و "|فتعل" وهما بناءان غير موجودين. فلما كان النقل يؤدي إلى

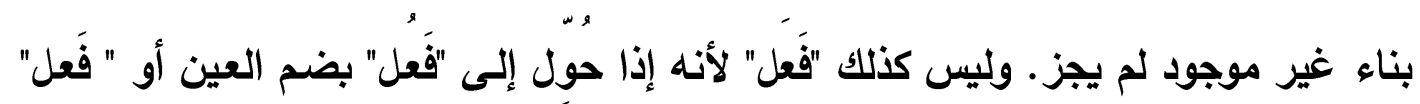

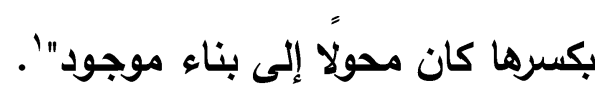

ويمكن القول إن المضارع من الصيخ التي يجب التصحيح في ماضيها فهو على

غرار المضارع من السالم: لا يتغير فيه شيء بأي نوع من أنواع التغيير، تقول " :غيد يفيد، وحور يحور، وناول يناول، وبايع يبايع، وسول يسول، وبين يبين، وتقول يتقول، 
وتبين يتبين، وتبايع يتبايع، وتهاون يتهاون، واحول يحول، واغيد يغيد، و اجتور يجتور، واحوال يحوال، واغياد يغياد."

أما المضارع مما يجب فيه الإعلال، فإنه يعتل أيضا، وهو في اعتلالهه على ثلاثة أنواع :الأول: نوع يعتل بالقلب وحده، وذلك المضارع من صيغتي " انفعل وافتعل" ، فإن حرف العلة فيهما ينقلب ألفا لتحركه وانفتاح مـا قبله، نحو " انقاد ينقاد، وانداح ينداح، واختار يختار، واشتار العسل يشتاره." ، والأصل في المضارع " ينقود، ويختير " على مثال ينطق ويجتمع، فوقع كل من الواو والياء متحركًا بعد فتحة فانقلب ألفا، فصارا " يختار، وينقـاد" ، والثاني :نـوع يعتل بالنقل وحده، وذلك المضـارع من الثلاثي الذي يجب فيه الإعلال، مـا لم يكن من باب " علم يعلم" ، فإنكك تنقل حركة الحرف المعتل إلى السـاكن الصحيع الذي قبله، نحو " قال يقول، وبـاع يبيع." والأصل في المضـارع " يقول، ويبيع "على مثال ينصر ويضرب، نقلت الضمة من الواو والكسرة من الياء إلى السـاكن الصحيح قبلهما، فصار يقول، ويبيع، والثالث :نوع يعتل بالنقل والتقب جميعا، وذلك مضارع الثلاثي الأي يجب فيه الإعلال إذا كان من باب " علم يعلم " والمضارع الواوي من صيغتي " أفعل واستفعل " نحو " خاف يخاف، وهاب يهاب، وكاد يكاد " ونحو " أقام يقيم، وأجاب يجيب، وأفاد يفيد " ونحو " استقام يستقيم" ، واستجاب يستجيب، واستفاد يستفيد .." 
ويمكن القول إن الواو تقلب ألفًا في "(فتعل" مالم تدل على التثارك؛ لذا صحت الواو

في نحو "اجتوروا واعتونوا وازدوجوا واعتوروا واحتوشوا واهتوشوا ،لأن هذه الأحرف في معنى "تفاعلوا" أي: تجاوروا، تعاونوا.

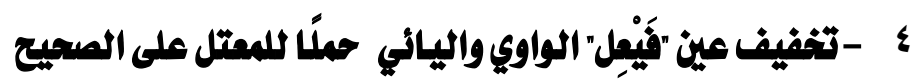

عندما تلتقي الواو و"الياء ويجتمعان في كلمـة واحدة، والسـابق منهما سـاكن وقبله

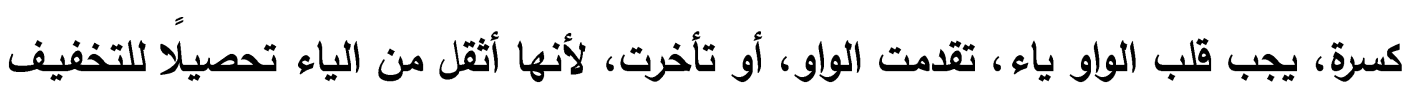
ما أمكن، ويجب حينئذ إدغام الياء "المنقلبة عن الواو" في الياء "السالمة لاجتماع المثلين، ومن التخفيف أيضًا حذف الياء ، يقول أبو الحسن:"... وإن شئت حذفت الياء المتحركة

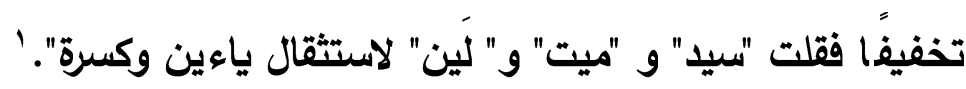
ويمكن القول إنـه يجوز تخفيف عين "فَبْعل" الواوي فيقال: "سيَّ" و " ميَتِ" في "

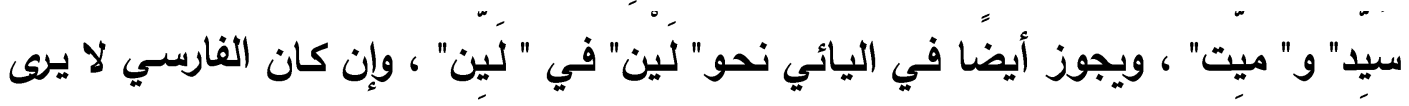
التخفيف في ذوات الياء قياسـا، فلا يجوز عنده: "بين" في " بين" قياسـا على " لَين" ، ويقيس ذلك في ذوات الواو، وحجته أن ذوات الواو قد كانت الواو فيها قد قلبت ياء فخففت بحذف إحدى الياءين منها لأن التغيير يأنس بالتغيير. فجواز التخفيف في المعتل حملًا على التخفيف في الصحيح، فالمعتل لا ينفرد بالبناء لا يكون للصحيح ، أو يأتي على بابه على الظاهر كما نقول "سيد" : "فَعيل".

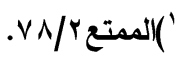

(حولية كلية الآداب- جامعة بني سويف عدد خاص - يناير (·. ) 


\section{ثالثًاء حمل الجمع على المفرد}

ذكر أبو الحسن إتباع الجمع للمفرد وذلك في:

\section{1 - الب الواوياءُ في الجمع لاعتلالها في المفرد}

ذكر أبو الحسن قلب الواو ياء لوقوعها بعد كسرة في فعل و فعال، يقول: "وإن كان على "فعلَ" من الواو بكسر الفاء وفتح العين جمعا لما قُلبت فيه الواو ياء أو ألفاً، فإن الواو تنقلب فيه ياء لانكسار مـا قبلها مـع أنهم أرادوا أن تعتل في الجمـع كما اعتلت في المفرد، وذلك نحو "قامـة وقيم" و" ديمـة و ديـم" و" قيمـة وقيم" ، والأصسل:" قوم" و "دوم" لأنهما من" قام يقوم" و"دام يدوم". فإن كانت الواو لـم تعتل في المفرد لـم تعتل في الجمـع نحو "زَوج وزِوجة" و"عود وعودة" إلا لفظة واحدة شدُت وهي "ثَور وثِيرة" فذهب أبوبكر إلى أن الذي أوجب قلب الواو ياء أن الأصدل "ثيارة " ك "حجارة" و"ذكارة" ،فقلبت الواو ياء لأجل الألف التي بعدها، كما قلبت في "سياط" جمع"سوط"' .

ويمكن القول إنه وجب قلب هذا الضرب في الجمـع لأنه قد كان في الواحد مقلوبـا

لانكسار ما قبل عينه، فلما قلب الأثقل في الواحل إلى الأخف ، وهو الياء، وجرى العمل من وجـه واحد جروا عليهه في الجمع ،و قالوا" :ديـم، وقيم، وحيل، أرادوا أن يكون بين" قيم، 


\section{د. حسن رمادي غانم نصر}

وتعل الواو إذا كانت في المفرد شبيهة بالمعلة- وهي الساكنة- نحو "سوط" و

"سياط" ، الواو في المفرد ساكنة ، وصارت الكسرة بمنزلة ياء قبلها، والألف تثبه الياء ،

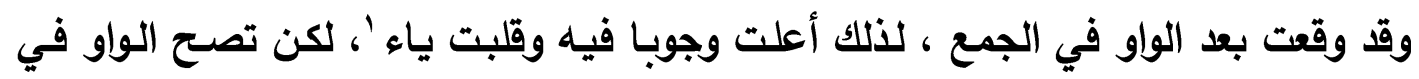

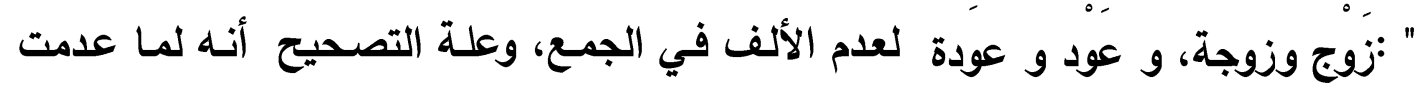

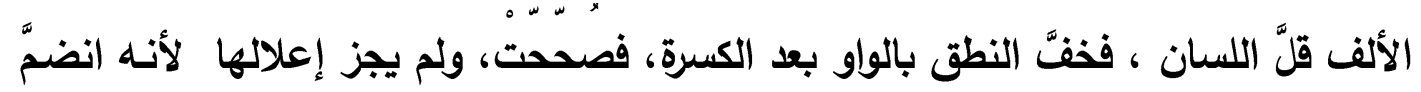

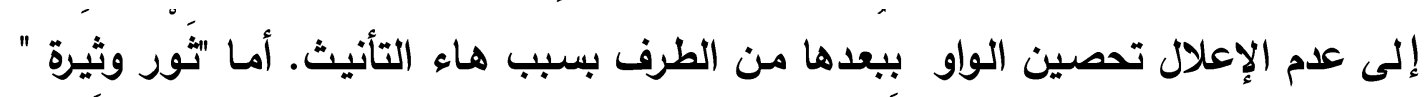
فليس بالمطرد، وقياسه" ثورة"بتصحيح الواو ،لكن قلبوها حيث كانت بعد كسرة ، واستثقلوا كما استثقلوا أن تثبت "ديم"، وهذا ليس بمطرد.

ويمكن القول إنه التقت الواو بالكسرة فأحدث نوعا من تكلف النطق وثقلهه مما أدى إلى إحداث مخالفة بين الصوتين المتجاورتين عن طريق قلب الواو(نصف الحركة) إلى نصف حركة من جنس الكسرة وهي الياء ليتم التماثل والانسجام بين الأصوات المتجاورة.

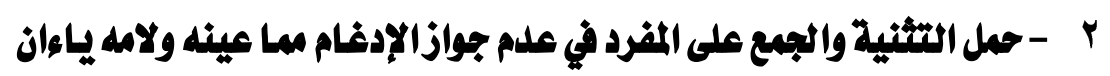
لا يجوز الإدغام فيما عينه ولامه ياءان؛ لذا يقول أبو الحسن: "وإن كانت

الحركة بناء فلا يخلو أن تكون متطرفة أو غير متطرفة ، فإن كانت متطرفة جاز الإظهار

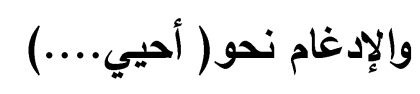

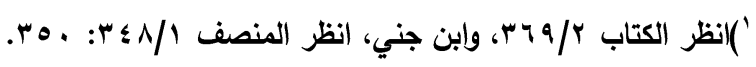

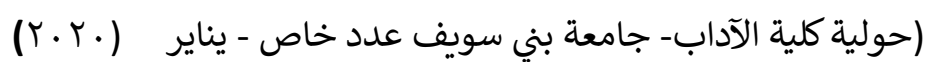


فإن لم تكن متطرفة فلا يخلو أن يكون بعدها علامتا التثنية أو علامتا الجمع ، أو

تاء التأنيث ، فبإن كان بعدها التثنيـة أو علامتا الجمـع لم يجز إلا الإظهار، وذلك نحو " محيِيان" و" حيِيان" و " محيِيات" والسبب في ذلك أن زيادتي الجمع إنما دخلت على الإفراد، فلما كان المفرد لو لم يلحقه شيء لا يجوز فيه الإدغام لأن الحركة إعراب حملت التثيـة

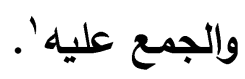

ويمكن القول -وهو كلام ابن عصفور ‘- إن المثلين إذا اجتمعا في هذا النوع فـلا يخلو من أن يكون الثاني ساكنًا أو متحركا، فإن كان سـاكنًا لم يجز الإدغام لأنه لا يجوز

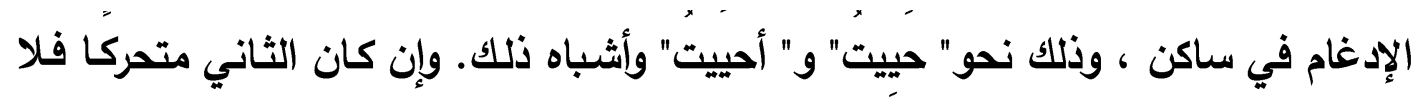
يخلو من أن يكون ما قبله مفتوحا أو غير مفتوح. فإن كان مـا قبله غير مفتوح فـلا تخلو الياء الثانية من أن تكون حركتها إعرابـا أو بناء. فإن كانت الحركة إعرابا لم تدغم لأن الإعراب عـارض يزول في حال الرقع والخفض، فيسكن الحرف فـلا يمكن الإدغام فيـه، فيحمل النصب في امتناع الإدغام على الرفع والخفض، وذلك نحو" لن يحي" و" رأيت محيِيا" فلا تدغم في " هو يحيي" ولا في" هو محِيك". وإن كانت الحركة بناء فلا يخلو من أن تكون متطرفة أو غير متطرفة، فإن كانت متطرفة جاز الإظهار والإدغام نحو "أُحيي"

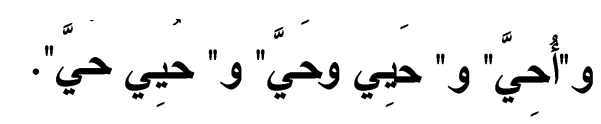




\section{د. حسن رمادي غانم نصر}

\section{كابعًا : المعل على المئى( ما يعامل معاملة فيره )}

الحمل على المعنى أن يكون الكلام في معنى كلام آخر فيحمل على ذلك المعنى، أو يكهون للكلمـة معنـى يخـالف لفظها فيحمـل الكـلام على المعنى دون اللفظ، قـال ابـن جني :"وقد شـاع عنهم حمل ظـاهر اللفظ على معقود المعنى وترك الظـاهر إليسه، وذلك كتذكير المؤنث، وتأنيث المذكر ، وإفراد الجماعة، وجمع المفرد ، وقد فاش عنهم". وعقد لـه

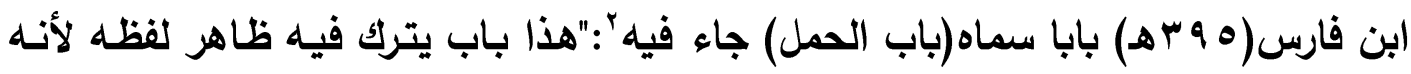
محمول على معنـاه"، ويعبر عنـه ب: حمله على كذا، التأويل ،ذهب بـه إلى كذا، مراعاة المعنى ،اعتبار المعنى ، الرد على المعنى، الإجراء على المعنى، الإعادة على المعنى ،أراد

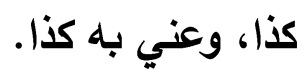
ومما علل به أبو الحسن الحمل على المعنى:

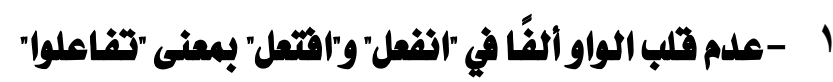

تعتل عين "انفعل" و"|فتعل" إذا كان الحرف الذي قبلها متحركًا في الأصل ،وممـا يمتنع فيه الإعلال فلا تقلب الواو المتحركة المفتوح مـا قبلها ألفًا إذا كانت هذه الواو عينا ل"|فتعل" الدال على معنى "التفاعل"، يقول أبو الحسن: "فإن وقعت الواو أو الياء عينّا في فعل على أزبـ من ثلاثة أحرف فإنها لا يخلو أن يكون ما قبل حرف العلة سـاكنا أو متحركا.

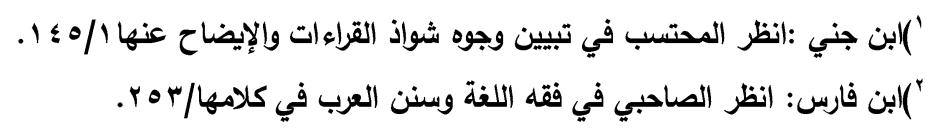


فإن كان متحركًا - سوذلك في "انفعل" و"|فتعل" نحو" انقاد" و" (قتاد" و"اختار"- فإنك تعامل مـا بعد السـاكن معاملـة فعل' 'على ثلاثة أحرف وذلك أن الأصل "انقود" و "|قتَود" و "اختِير" ،فعاملت "قاد" من "انقاد" و "تاد" من" اقتاد" و "تار" من "اختار" معاملة" قال" و"باع" فأعللت كما أعلاتهما. ولا يصح شيء من ذلك إلا أن يكون في معنى مالا يعتل نحو `"جتوروا" و "ا هتوشـوا" و "اعتونْوا" لأنها فِي معنـى" تجاوروا" و"تعاونوا" و"تهاوشـوا" ،ألا ترى أن الفعل فيه ليس فعل واحد. فبابه أن يكون على وزن" تفاعل" ، وكذلك جميع ما يأتي على معنى

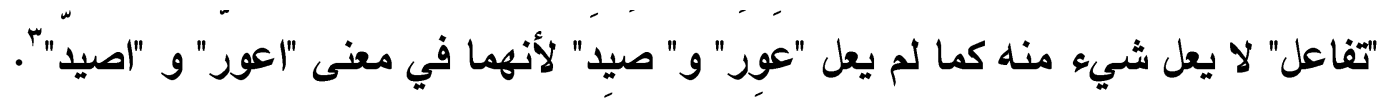
ويمكن القول عدم قلب الواو ألفًا في "انفعل" و"|فتعل" بمعنى "تفاعلوا" ؛ لذا حمل "قاد" و "تاد" على "قال" و"باع". فمجيء اليائي معـلَّ لا يشكل مشكلة دلالية، بعكس مـا يحدثه ما كان واوي العين الذي يلتبس -فيما لو أعل- بما لا يدل على معنى(تفاعلوا)-أي المشاركة.

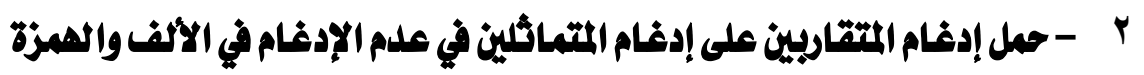

يحمل إدغام المتقاربين على إدغام المثلين سواء في جواز إدغام أو منعه سواء لعلة صرفية أو صوتية، ومنه الألف لا تدغم لا في مثلها ولا في مقاربها، وكذلك يستقبح

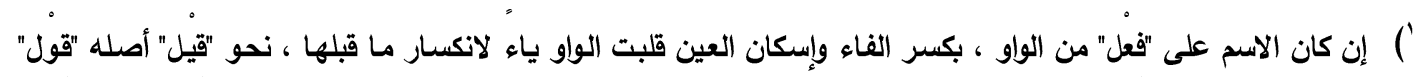

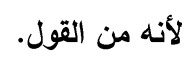

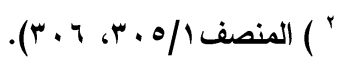

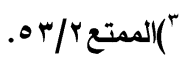




\section{د. حسن رمادي غانم نصر}

الإدغام في الهمزتين، فكمـا امتـع فيهمـا إدعام المتقاربين فكذلك هنـا امتـع فيهما إدغام

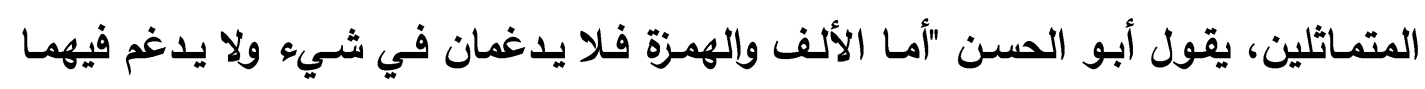
شيء، والسبب في ذلك أن إدغام المتقاربين محمول على إدغام المثلين. فلمـا امتـع فيهما إدغام المثلين -كما ذكرنا في فصل إدغام المثلين - امتنع فيهما إدغام المتقاربين' . يمتنع الإدغام أيضا في الألفين؛ لتعذر الإدغام لتعذر حركتهما، ووجوب حركة المدغم فيه؟" . ويمكن القول إن الألف لا تدغم البتة لا في مثلها ولا في مقاربها؛ فلأنّه إن كان في الأدخل في الفم فلمـا يؤدي إليهه مـن ذهاب مدها من غير مـا يقوم مقامـه، وإن كان في الأدخل منها في الحلق وهو الهمزة فكذلك، ولاجتماع الهمزتين ولإدغام الأدخل في الفم في الأدخل في الحلقَّ ـ فالألف ساكنة أبدا فلا يمكن إدغام مـا قبلها فيها، ولا يمكن إدغامها لأن الحرف إنما يدغم في مثله وليس للألف مثل متحرك فيصـح الإدغام فيه ، ولذا امتـع إدغام الألفين مطلقًا، وأما الهمزة فثقيلة جدَّا، ولذلك يخففها أهل التخفيف منفردة، فإذا انضم إليها غيرها ازداد الثقل، فألزمت إحداهما البدل . . . فيزول اجتماع المثلين فـلا يدغم إلا أن تكونا عينين نحو :سأل ورأس، فإنها تدغم ولا تبدل؛ لأنه لو أبلات إحداهما لاختلفت العينان، والعينان أبدا في كلام العرب لا يكونان إلا مثلين ـ ويبدو أنها لا تتسم بصفات قوة تجعلها تؤثر في غيرها من الأصوات، وإدغام المتقاربين يتطلب تغيير الحرف إلى مثله أو

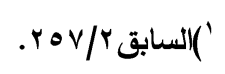

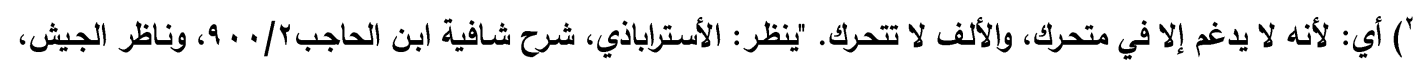

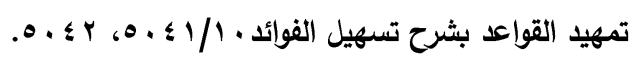

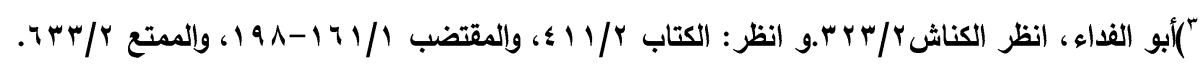


إلى غيره، فإذا قلبت الهمزة إلى مثلها ، اجتمعت همزتان وهذا يزداد ثقلًا، فيتعارض هذا الثقل مع الهدف من الإدغام وهو طلب الخفة.

ويعود تفسير المحدثين إلى أن الألف ساكنة ، وليست من الصوامت ، فلا يجوز أن يدغم صائت، أي حركة ، في صامت وذلك بببب التباعد بينهما.

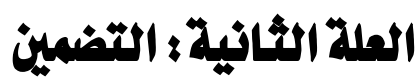

ضمَّن الثـيء الثـيء : أودعه إيـاه كما تودع الوعاء المتاعَ'، وفي الاصطلاح:

إثراب لفظ معنى لفظ وإعطاؤه حكمه لتؤدي الكلمة مؤدى كلمتين بأو : إعطاء الثيء معنى الثيء، أو : إجراء أحكام لفظ على آخر ليدل على معنـاهّ.والرأي المشهور أن التضمين يكون في الأفعال والأسماء والحروف؛ وهو من باب التوسع في الفعل والحرف، بدليل قول ابن جني :" اعلم أن الفعل إذا كان بمعنى فعل آخر وكان أحدهما يتعدى بحرف والآخر بآخر، فإن العرب قد تتسع فتوقع أحد الحرفين موقع صاحبه إيذانًا بأن هذا الفعل في معنى الآخر؛ فلذلك جيء معه بالحرف المعتاد مـع ما هو في معناه".

$$
\begin{aligned}
& \text { 'بابن منظور، نظر لسان العرب (ض م ن) }
\end{aligned}
$$

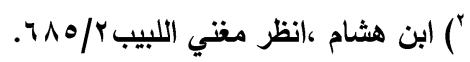

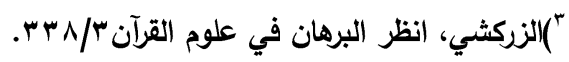

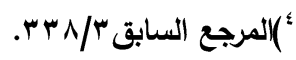

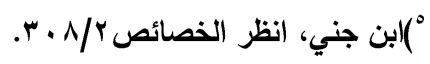




\section{د. حسن رمادي غانم نصر}

وعلة التضمين هنا يـخل تحتها: حمل معاني الأفعال بعضها على بعض، وكذلك حمل الحروف بعضها على معاني بعض لما بينها من الارتباط والاتصال، واندراج بعض أجزاء الحمل ضمن التضمين لهو من باب تداخل العلل وتكاملها وارتباط بعضها ببعض ، والتفريق بينها أحيانا يحتاج لدقة متناهية تحكمها السياق، ومن مسائله ما يأتي:

\section{أوبًا أهمل' ملى الثمل}

الحمل على الفعل مـن بـاب حمل الأصسول على الفروع، كمـا حملـوا الفروع على الأصـول لإيثارهم تشبيه الأثـياء بعضها ببعض، ومـن ذلك إعلال المصدر لإعلال فعله، وتصحيحه لصحته، نحو: قمت قواما، وقاومت قواما.'"وقد علل أبو الحسن لبعض الأشياء حملاً على الفعل، منها:

\section{ا - الإعلال في "اثفعل" و" اقتعل" حمكا على الفمل}

وجب إعلال الفعل الماضي المزيد حملًا على الثلاثي المجرد، كذلك أُعل مـالم يسمّ فاعله حمـلًا على مـا ســي فـاعله، يقول أبو الحسن:" وإذا بنيته للمفعول عاملت مـا بعد السـاكن معاملـة الفعل علـى ثلاثـة أحـرف. فمـن قـال في "قـال" و"بـاع" : " قيـل" و "بيـع" قال:"انقيد" و " اختير" و" اقتيد" .ومن أثشار إلى الضمة هناك فأشمَّ أشم هنا.ومن قال "قُول" و " بوع" قال: " انقُود" و" اختَور" و" اقتُود".وكذلك إذا أسندته إلى ضمير المفعول المتكلم أو أو

') مصطلح "الحمل" هنا ضمن "علة التضمين" من باب تداخل العلل وتقاربها وتكاملها دليلًا على ثراء تلك العلل كثراء لغتنا. العظيمة.

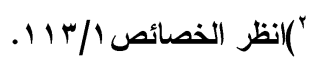

(حولية كلية الآداب- جامعة بني سويف عدد خاص - يناير (·. (Y) ) 


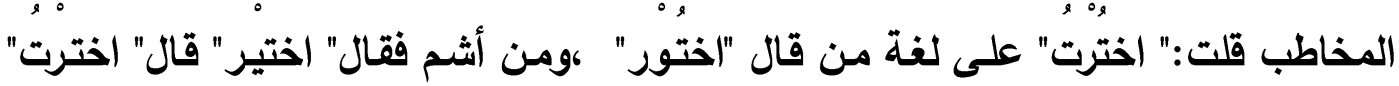
فأشم. ومن ترك الإشمام فقال "اختير" ترك الإثمام فقال" اخترت" لأنه لا يلخله لبس كالذي يـخل في "بعت". والعمل في إعلال ذلك كله كالعمل في إعلال "قيـل" و "بيع"' . وكذلك المستقبل-مبنيًا كان للفاعل أو المفعول - واسم الفاعل والمفعول، يجري ما بعد السـاكن في جميع ذلك مجرى الفعل على ثلاثتة أحرف ، فتقول" ينْقاد" و" ينقاد" و "يقتاد" و "يقْتاد" و "مقتاد" و" منْاد" ـ فتجري" قاد" و "تاد" في جميع ذلك مجرى "قال" و"باع" ؟.

ويمكن القول إنها تجرى اللَفَات الثَلَاث في وزن "انفعل" وا"فتعل" من الأجوف المعل نَحْو ا"تقيد واختير وإنقود واختور وإنقيد واختير بخَلَف غَيره ولَّو اعتل نَحْو اعتور به، و يقال إن الأصل الضم، لكن لمناسبة التاء كسرت في انقيد واختير، ،قيل :اختور وانقُود على الأصل، وإنما يعلل ما جاء على خلاف الأصل، فيقال :انقيد لمناسبة الياء؛ لأن الانتقال من ضم إلى كسر هذا فيه ثقل.

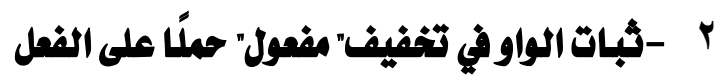

ذكر أبو الحسن ما قاله سيبويـه من نحو :"مسو" فينبغي أن يكون أبدل من الهمزة الواو، وأدغم الواو التي هي عين فيها، لأن المبقى عنده عين الفعل، وواو مفعول محذوفة، و قول أبي الحسن في مسوء بالتخفيف القياسي: مسو، كما يقول في مقروءة: مقروة،

$$
\begin{aligned}
& \text { ') المتع r/ } \\
& \text { "ك/السابق r/ }
\end{aligned}
$$

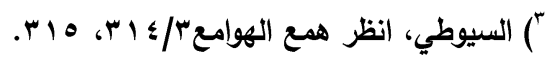




\section{د. حسن رمادي غانم نصر}

وفي قول سيبويـه مسـو، ومقرو، لأن الـواو العين وليست المدة التي في مثل الهدوء،

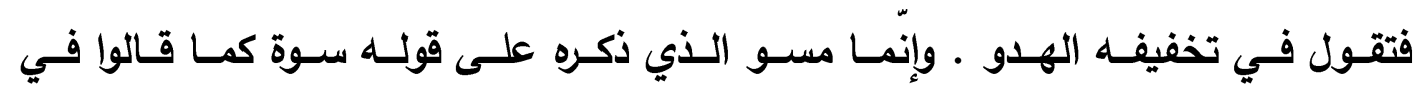
المنفصل :أونـت فهذا التخفيف على القولين جميعا ، حيث يقول" وثمـرة الخـلاف بين سيبويه وأبي الحسن تظهر في تخفيف " مسوء" وأمثاله. قال أبو الفتح في " القد" : سـألني أبو علي عن تخفيف " مسوء" فقلت: أما على قول أبي الحسن فأقول " رأيت مسوَّا" لأنها عنده واو مفعول. وأمـا على مذهب سيبويـه فأقول" أيـن مسوا" بتحريك الواو لأنها عنده العين. فقال لي أبو علي: كذلك هو، اللهم إلا أن تقول إنهم حملوا الماضي على المضارع ، وإذا كانت العرب قد حملت المضـارع في الإعلال على الماضـي ، مـع أن الأكثر على أنَّ المضارع، فالأحرى أن يحمل الماضي على المضارع في ثبات الواو". ويمكن القول إن مذهب الخليل، وسيبويها :أن المحذوف واو المدة فأصل نحو: مبيع مبيوع نقلت الحركة، فالتقت الياء والواو ساكنين، فحذفت الواو، فبقى :مبيع، فكسر ما قبل الياء لتصح ، وثمرة الخلاف أنه إذا خففت مسوء على مذهبهما قيل: مسو بالتخفيف كما تقـول: خب، وعلى مـذهب أبـي الحسـن : مسـو بالتثــيد كمـا تقـول مقـرو.فإذا خففـت 
همزة" مسوء "فقياس قول سييويـه أن يحرك الواو؛ لأنه يرى أن المحذوف واو مفعول الزائد، وعند أبي الحسن يدغم، يقوله مسو يقلب ويدغم كما تقول مقروءة' .

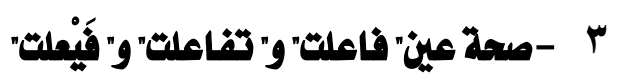

مما يمتنع فيه قلب الواو ياء أن الواو ليست بلازمـة ولا بأصل، يقول أبو الحسن: "وكذلك تصح في المضارع، وفي الفعل المبني للمفعول، وإم الفاعل، كما صحَّت في الفعل الماضي المبني للفاعل. فتقول في الماضي المبني للمفعول" سويِ" و"عوون" و" تسويرِ" و"

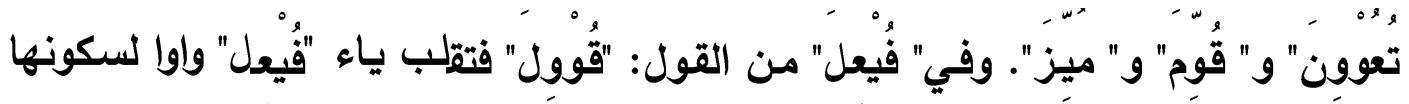
وإنضمام ما قبلها، كما فعلت في "بوطر". ولا تدغم الواو من " سوير" و" عووِن" و" تسوير" و" تعوون" لأنها بدل من الألف في " ساير" و" تساير" و" عاون" ، فكما لا تُّغم الألف في الياء ( أو الواو) فكذلك ما هو بدل منها. ويمكن القول إنه لا تدُفم الواو من " قُوْولِ" في الواو التي بعدها لأنها صـارت مدَّة أثبهت الواو المنقلبة من الألف في " سويِر" وأمثاله، فلم تدغم كما لم تدغم واو " سوير" فيما بعدها.

وكذلك حكم كل حرف قد كان لغير المد ثم صار في بعض المواضـع مدة ، لا يدغم لثبهه بالألف في " فاعل" من حيث هو للمد، ولا يلزم كما لم تلزم الالف . 


\section{د. حسن رمادي غانم نصر}

فإن كان حرف المد لازما أُدغم نحو " مغْزو' " أُدغمت واو " مفعول" في الواو التي بعدها لما كانت لازمة لكونها في لفظ لا يتصرف.

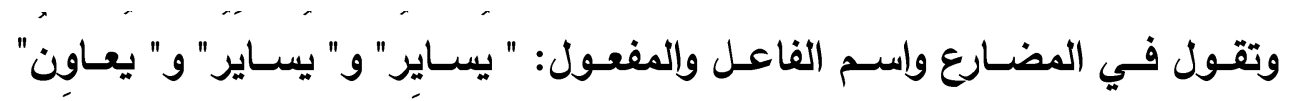

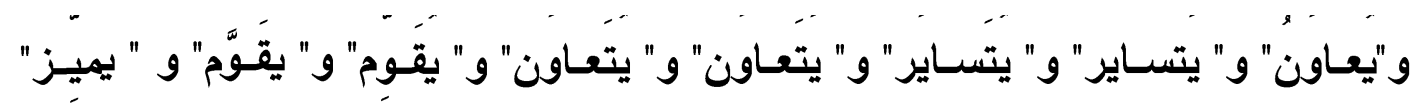

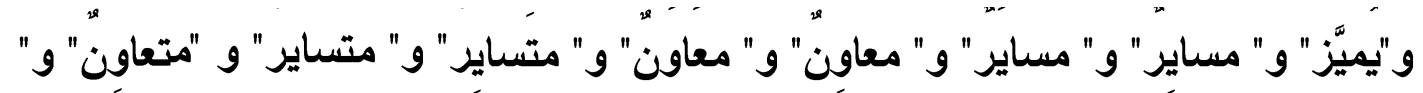

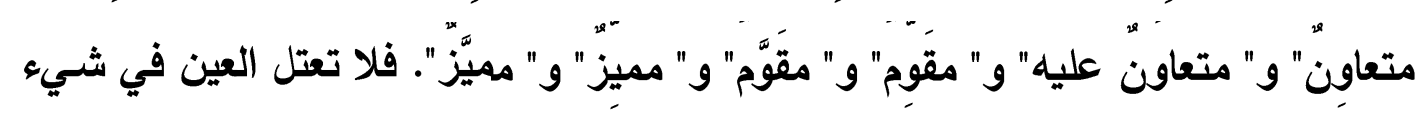
من ذلك.

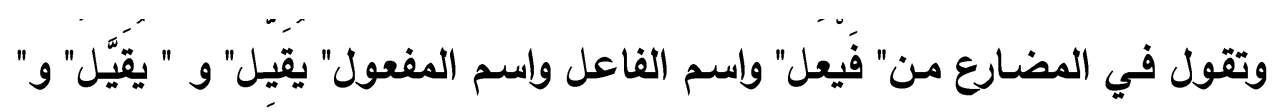

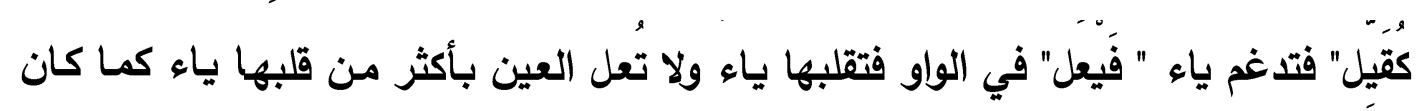

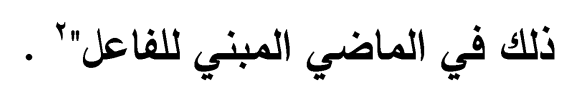

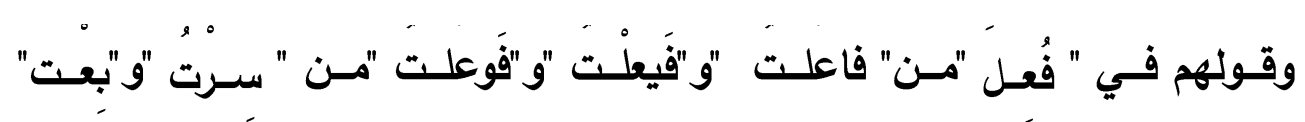

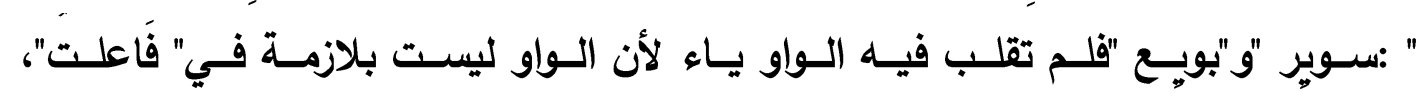

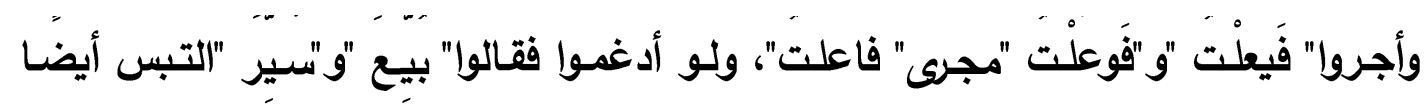

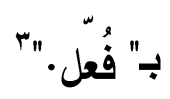

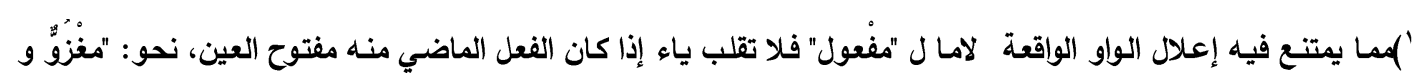
مدعوّ"

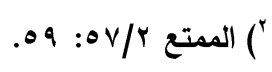

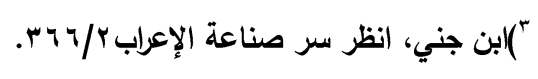

(حولية كلية الآداب- جامعة بني سويف عدد خاص - يناير (·. ) ) 
ويمكن القول أيضًا إن واو "سوير" مدة ، وما كان مدَّا فالإدغام فيه محال ،ولمـا

انتفت الحاجة إلى الإدغام انتفت الحاجة إلى مقدماته وهو الإعلال.

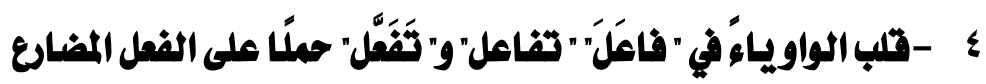

تقلب الواو ياء في نحو "تغازيت" و "ترجَّيت" مع عدم الكسرة قبل الواو، ويحتجُ أبو

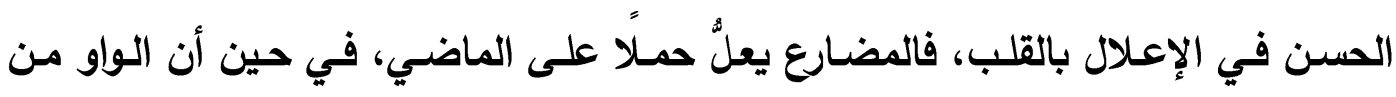

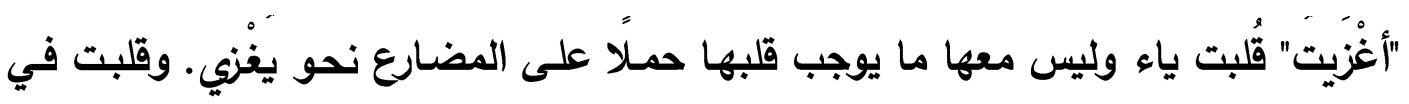
المضارع لانكسار ما قبلها ، كما قلبت في مثل: شَقي ، و رَضي، حيث يقول:" ...فإن قيل

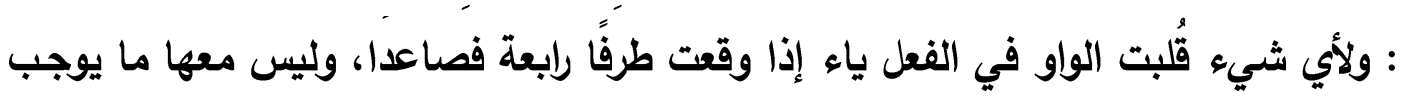
قلبها يـاء؟ فالجواب أنها في ذلك محمولـة على المضـارع، نحو" يغني" و" يستدني" و" يستدعي"، وقلبت في المضارع ياء لانكسار ما قبلها كما قلبت في مثل" شَقي" و" رضي". فإن قيل: فلأي شيء انقلبت الواو ياء في مثل" تفاعل" و" تفعَّل" نحو" ترجَّى" و" تغانى" وليس لها ما يوجب قلبها في الماضي ولا في المضارع، ألا ترى أن مـا قبل الآخر في المضارع مفتوح كما أن الماضي كنلك ندو " يتغانى" و" يترجَّى"، فالجواب أن التاء في " ترجَّى" و" تغانى" وأمثالهما إنمـا دخلت على" رجَّى" و"غانى".وقد كان وجب قلب الواو ياء

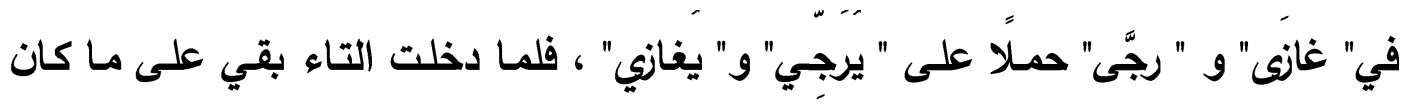

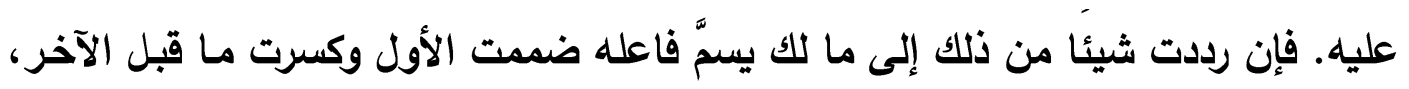

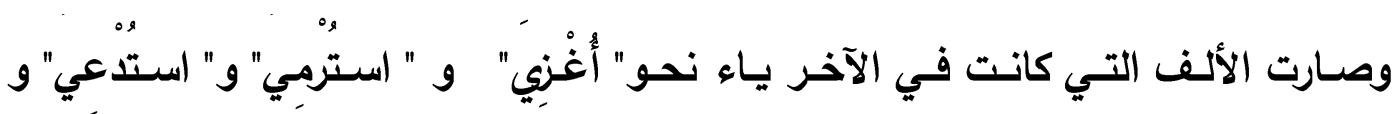




\section{د. حسن رمادي غانم نصر}

"استُني" من ذوات الواو كان الفعل أو من ذوات الياء.وإنما قَلبت الواو ياء إما بالحمل على

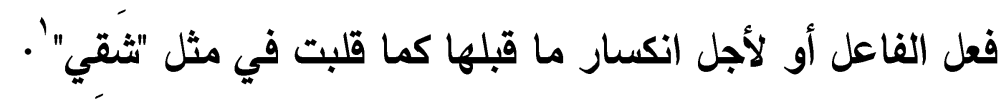
ويمكن القول إن الواو إذا وقعت رابعة فصاعدا قُلبت ياء حملًا على المضارع، وإنمّا

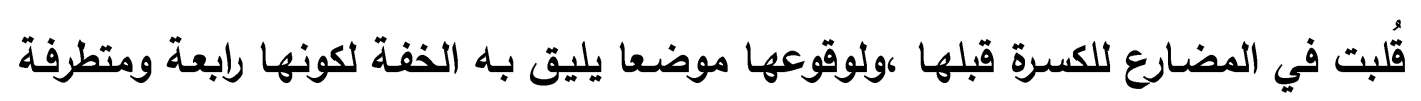

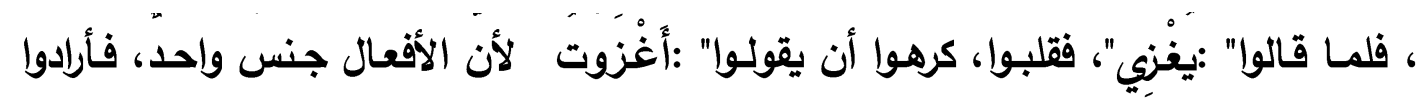

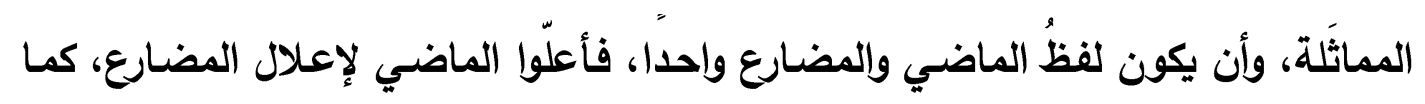

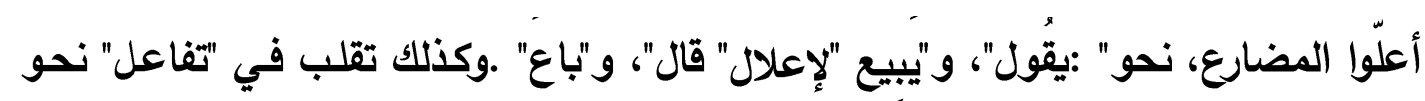

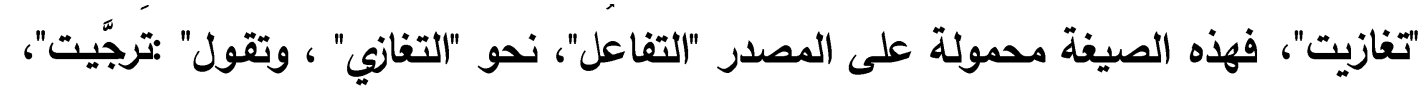

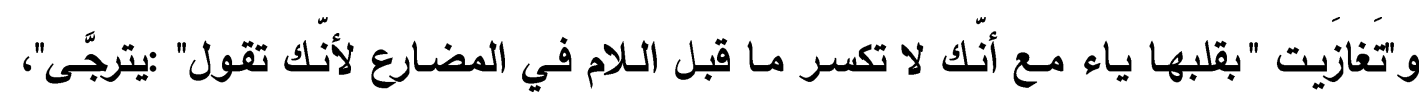

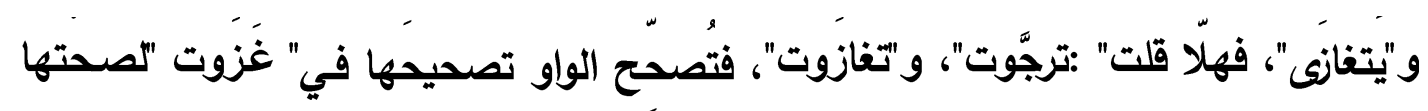

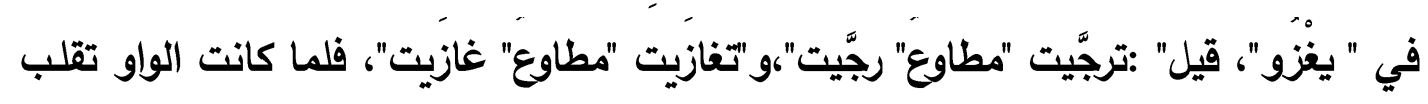
في الأصل لانكسار ما قبل لامه في المضارع نحو" :يرجِي"، و"يغانِي"، بقيت على حالها بعد

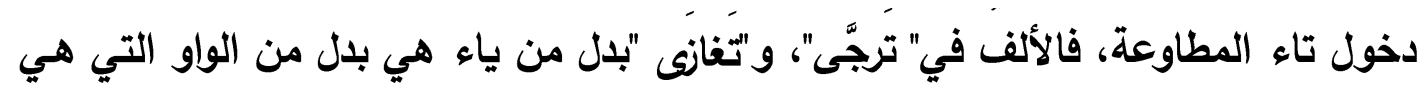

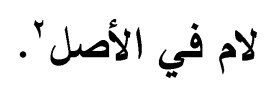

ويمكن تفسير ذلك التعديل الصوتي بقلب الواو الثقيلة إلى نصف حركة أخف منها وهي الياء تخفيفًا من صعوبة النطق بهذا المقطع المشتمل على الحركة المزدوجة الواويـة.

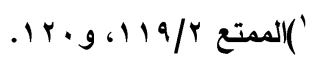

$$
\begin{aligned}
& \text { ץ) }
\end{aligned}
$$

( حولية كلية الآداب- جامعة بني سويف عدد خاص - يناير (·. ) 
وقعت الواو في خاتمة مقطع طويل مضاعف مغلق(ص ح ص ص) ،وزاد ثقله باشتماله على الحركة المزدوجة ذلك أن الواو أثقل حروف العلة ، لهذا عمد الناطق إلى إجراء تعديل صوتي من شأنه أن يخفف من صعوبة النطق بهذا المقطع المشتمل على الحركة المزدوجة الواوية (مقوول).

\section{0 - مهل اللفيف المثروق على المثال والمتل}

يحمل معتل الواو والللام على المثال والناقص في جميع الأحكام، يقول أبو الحسن: "فأما اعتلال الفاء والللام وصحة العين فالأي يتصور في ذلك أن تكون الفاء والتلام واويـن أو ياءين أو واوا وياء، وإما أن تكون الفاء واوا والللام ياء أو العكس. فأما كون الفاء والللام واوين فلم يجئ من ذلك شيء. وأما كونهما ياءين فلم يجئ من ذلك إلا " يديت إليه يدا". وأما كون الفاء واوا والتلام ياء فكثير في كلامهم نحو" وقيت" و " وشيت" و "ولِيت"، وأمـا عكسه فلم يجئ. وجميع ما جاء من المعتل اللام والفاء فيحمل أوله على باب " وعد" وآخره على باب " رمى" في جميع أحكامها.

ويمكن القول إن اللفيف المفروق مما فاؤه واو ولامه ياء كثير ويحمل على المثال والناقص، أما اللفيف المفروق مما فاؤه ياء ولامه واو فغير مستعمل ولم يجئ منه شيء. 7

يطرد الإعلال بالنقل في ما يجيء على "|فَفْعل" و "استَفْل" مما كانت العين واوا أو ياء من الأفعال الماضية، كما يطرد الإعلال بالنقل في الفعل المضـارع الذي اعتلت عين 


\section{د. حسن رمادي غانم نصر}

ماضيه، يقول أبو الحسن: "فإن كان الساكن حرفًا صحيحًا فلا يخلو أن يكون الفعل على وزن " افعلَّ" أو " افعال" أو على غير ذلك من الأوزان. فإن كان على غير ذلك من الأوزان

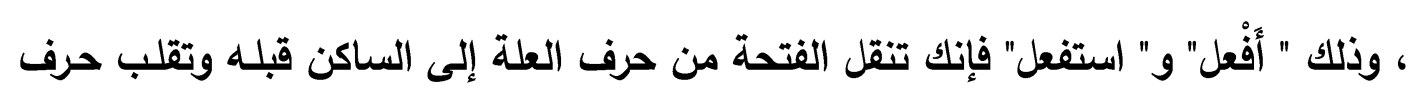

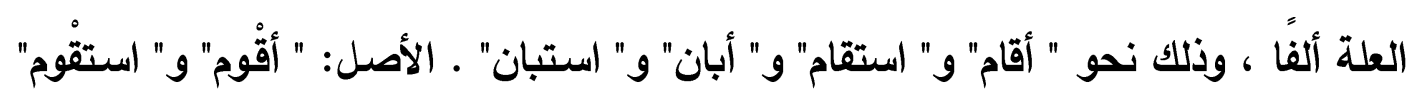

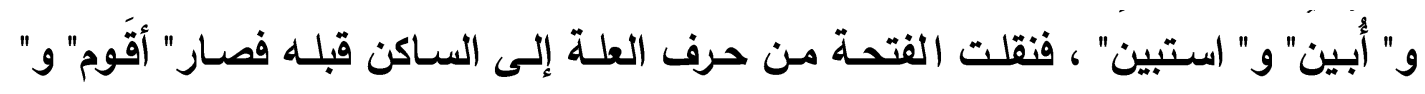

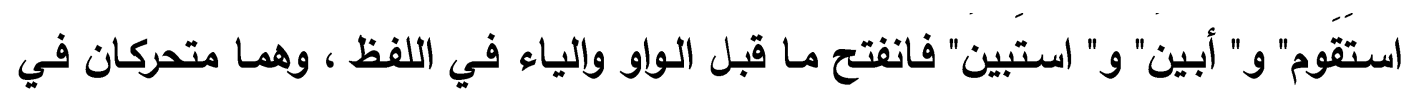

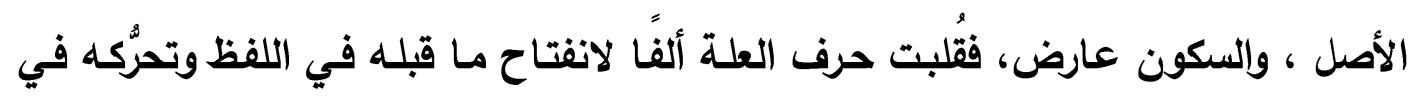

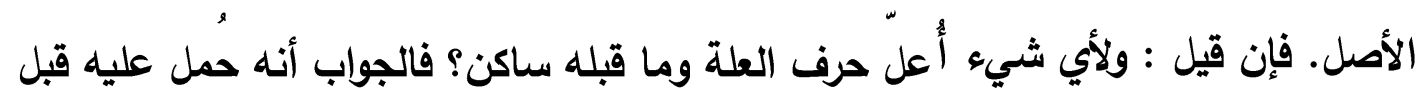

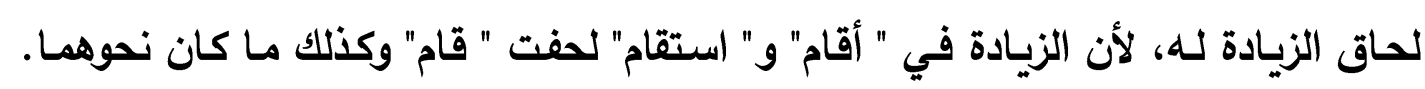
وكذلك أيضًا تفعل بالمضارع ، فتقول: " يقيم" و" يقام" و" يستقيم" و" يستقام" ، والأصل: "

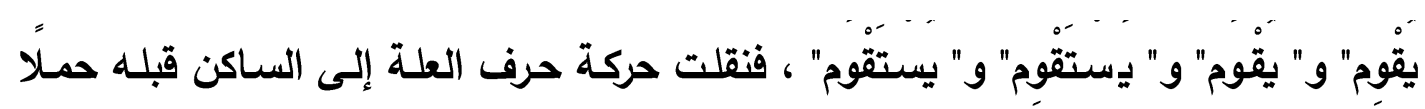

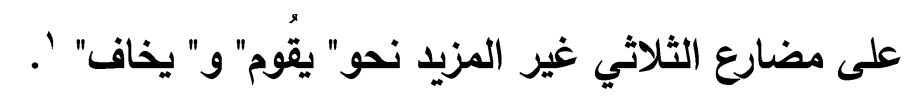
ويمكن القول إن الداعي إلـى الإعلال بالقلب أو بالقلب وبالنقل معـا في الفعل

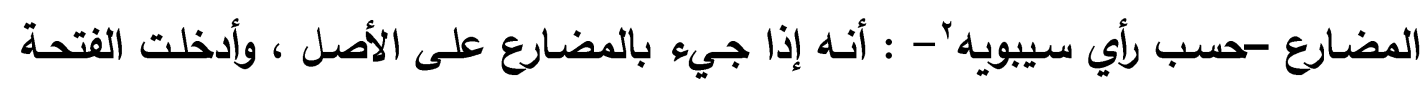

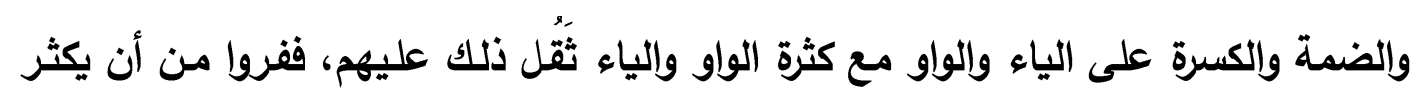
هذا في الاستعمال اللغوي، فكان الحذف والإسكان أخف عليهم.

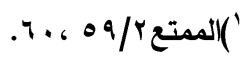

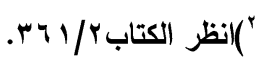

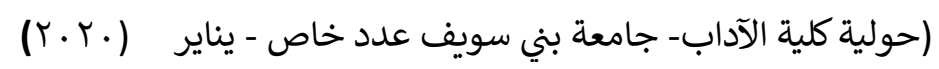




\section{V - نقل حركة حرف الملة إلى الساكن قبله في المشاع المزيل حملا على المشارع المجرد}

يرى أبو الحسدن أن حركة حرف العلة تنقل إلى السـاكن قبله حملَّ على مضـارع الثلاثي غير المزيد نحو: يقوم" و" يخاف". فيقول :" ...وكذلك أيضًا تفعل بالمضارع فتقول"

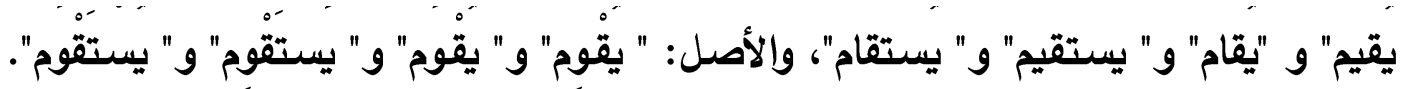
وإن جاءت الياء أو الواو بعد فتحة قلبت ألفًا لانفتاح ما قبلها في اللفظ وتحركها في الأصل نحو "يقام" و" يستقام" و" يبان" و" يستبان" وكذلك اسم الفاعل واسم المفعول تُعلهمـا حملًا على الفعل وذلك نحو" مستبين" و" مستبان" و" مستقيم" و "مستقام" و" مقيم" و "مقام" و"

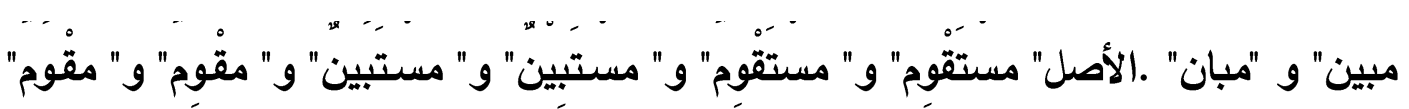

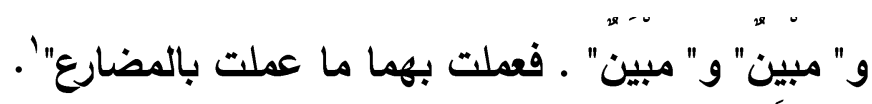

ويمكن القول إن الإعـلال بنقل حركة الواو والياء إلى السـاكن الصـيح قبلها إذا كانتا عينًا لشبهه في المضارع سواء حصل هذا في مضارع مزيـا أم في اسم يجري على الأفعال المعتلة العينات ،لا فصل في هذا بين الأسماء والأفعال، وأسماء الفاعلين في هذا والمفعولين والظروف والمصـادر سـواء لأنها كلها جاريـة على الأفعـال، فيجب إعلالها لاعتلال أفعالها. 


\section{1 - إعلال عين المصدر الزائل على ثلاثلة احرف}

ذكر أبو الحسن حمل الاسم الزائد على ثلاثة أحرف على الفعل "المصدر المأخوذ من الفعل"- على غير وزن الفعل والجاري على الفعل ، فيقول: "وإن كان الاسم على غير وزن الفعل فلا يخلو من أن يكون جاريا على الفعل أو لا يكون، ونعني بالجاري: مـا يكون

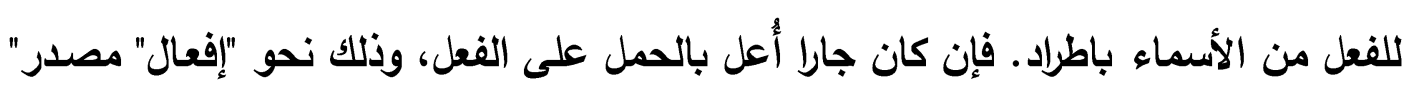

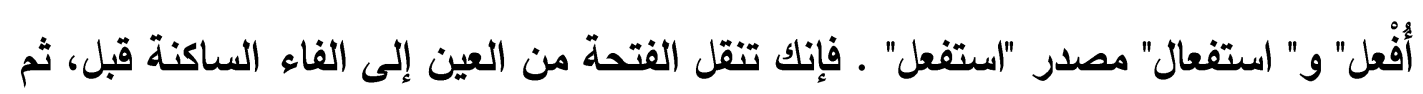
تقلب حرف العلة لتحرُكه في الأصل وانفتاح ما قبله في اللفظ، فيلتقي ألفان: الألف المبدلة من حرف العلة والألف الزائدة قبل الآخر، فتحذف الواحدة لالتقاء السـاكنين. فمذهب الخليل وسيبويه أن المحذوفة الزائدة، ومذهب الأخفش أن المدذوفة الأصلية "'.وكذنلك "انفعال" مصدر " انفعل" المعتل العين، إن كانت من ذوات الواو قلبت الواو ياء، وذلك نحو" انقياد "مصدر" انقاد" أصله" انقواد" فجعلت" قواد" من " انقواد" بمنزلة" قيام". فقلبت الواو ياء كما

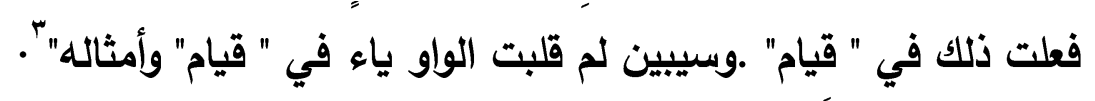
قلب الواو ياء" في" فعال" إذا كان مصدراً لفعل معتل العين بالواو ، أو جمعاً لمفرد

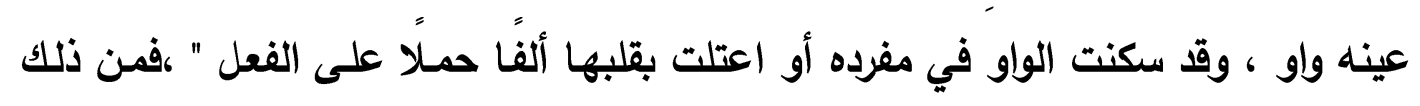

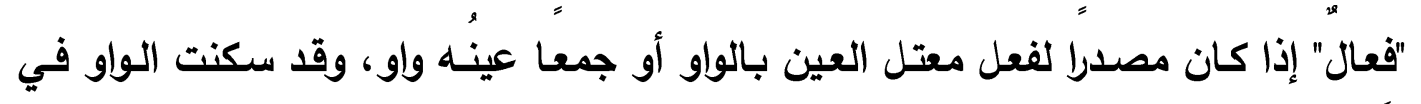

'الم 'الم يذكر ابن عصفور أمثلة.

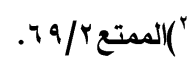

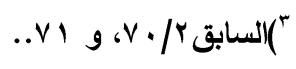

(حولية كلية الآداب- جامعة بني سويف عدد خاص - يناير (·. ) ) 
مفرده أو اعتلت بقلبها ألفًا فإنكك تقلب الواو ياء؛، وذلك نحو" قام قيامـا" و " سَوطُو سياط"

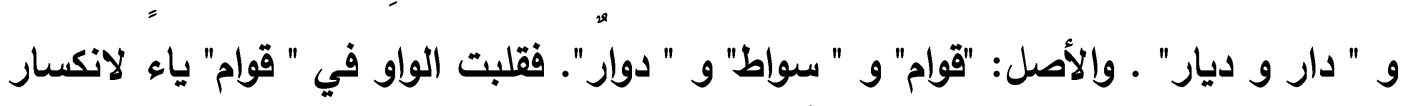

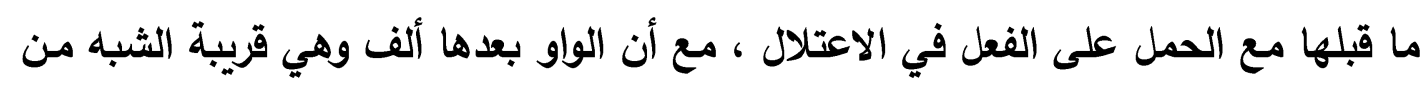
الياء.

فلما اجتمعت هذه الأسباب خفّف اللفظ بقلب الواو ياء، ولو نقص شيء من هذه

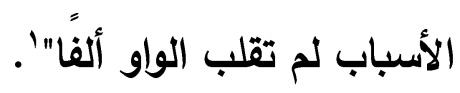
ويمكن القول إن الإعلال المذكور يجب للواو الواقعة عينا لمصدر فعل معتل

العين بثرط أن يكون بعدها ألف نحو صام صياما، أصله صوام، لكنه لما أعلت عينه في الفعل استثقل بقاؤها في المصدر بعد كسرة، وقبل حرف يثبه الياء، فاعتل بقلبها ياء -

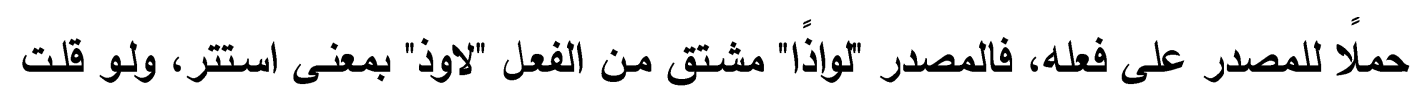

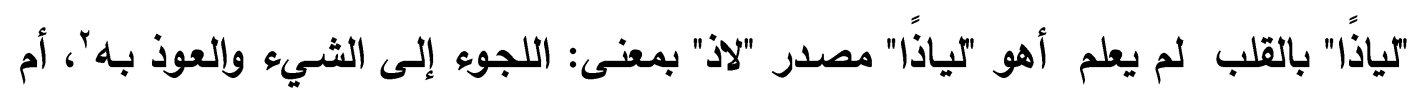
هو مصدر "لاوذ" بمعنى :استتر، وبالتالي تصح الواو ويجيء المصدر بالأصل إذا كانت

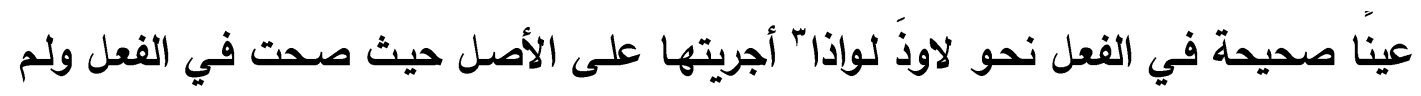

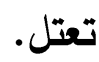

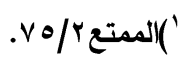

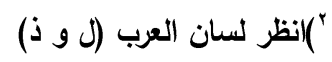

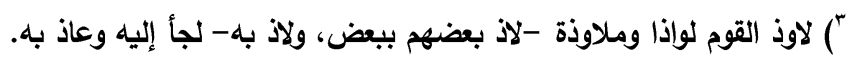


كما يمكن القول إن الواو تقلب ياء استثقالا للواو بعد الكسرة وهروبا من تتابع

الكسرة والواو والفتحة طلبا لتقليل الجها ، والخفة الناتجة عن تحقيق الانسجام الصوتي.

\section{9 - - إعلال المصلدر الزائل على ثلاثلة أحرف إعلال الفهل}

ذكر أبو الحسن إعلال الاسم الزائد على ثلاثة أحرف إعلال فعله وهو مخالف لـه

في جنس الزيادة، حيث يقول:" وإن كان مخالفًا له في جنس الزيادة فإنـه يعل إعلال الفعل الفهل

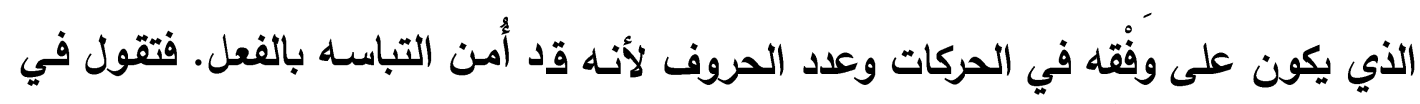

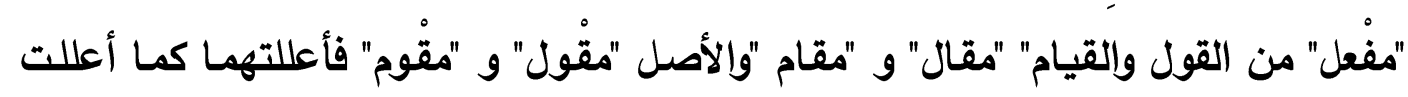

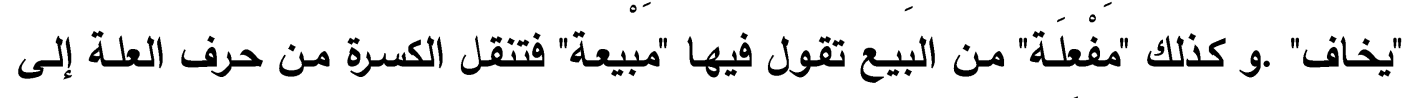

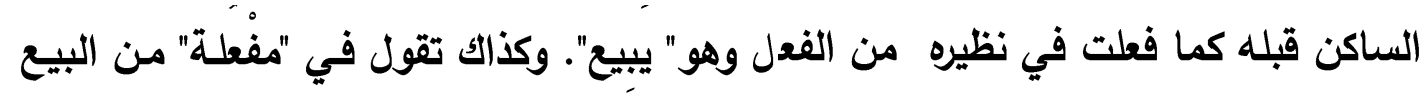
على مذهب سيبويه لأنك إذا نقلت الضمة من الياء إلى السـاكن قبلها جاءت الياء ساكنة

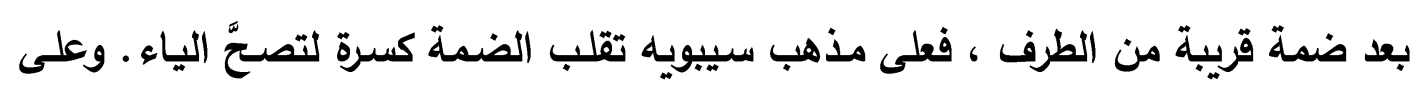

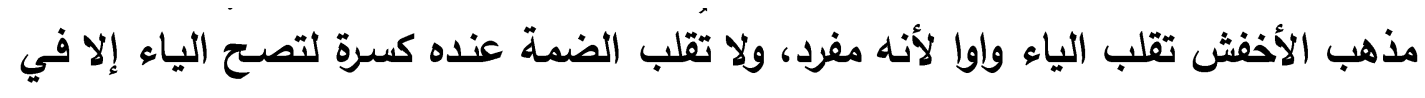

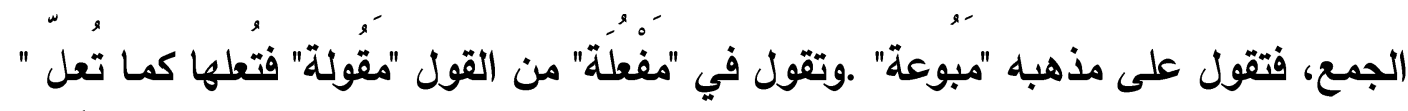

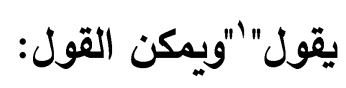

1- إن جميع الأسماء الجاريـة على الأفعال المعتلة العين، نحو أسماء الأفعال،

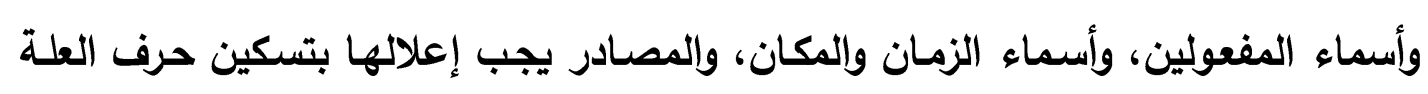


فيها الواو أو الياء، ونقل حركته إلى الساكن الصحيح قبله. وجميع الأمثلة التي ذكرها ابن عصفور جرى فيها الإعلال بالنقل كما جرى الإعلال نفسه في أفعالها وإن اختلفت في زيادتها وهي الميم.

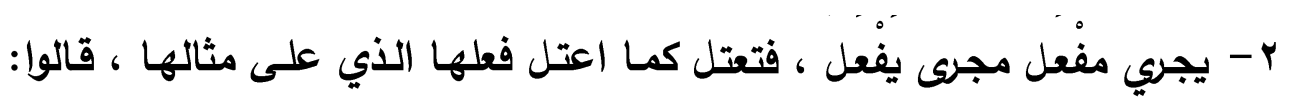
مخافة أجروها مجرى يخاف، وكذلك مَفْعل مجرى يَفْل.

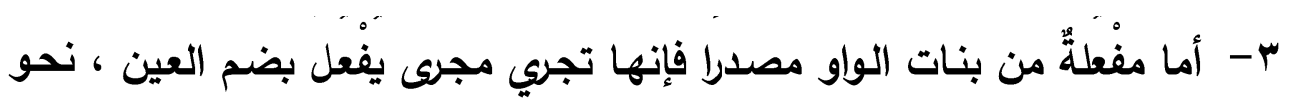
المعونـة، والمشـورة، والمثوبـة، وقد جرى فيها إعلال بالنقل فقط، ومـا يدل على أن هذه مصادر على وزن مفعلة وليس بمفعولة أن المصدر لا يجيء على مفعولَةٍة. وأما مفُعلة من بنات الياء فإنما تجيء على مثال مفْعلة، نحو معيشة فإنها تصلح أن تكون مفعلة و مفْظُة بضم العين وكسرها.

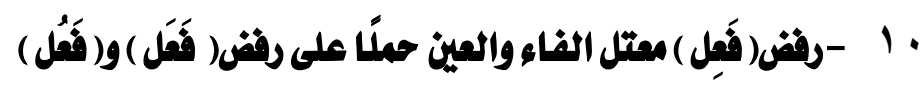

من الحمل بالرفض مـا ذكره ابن عصفور حيث يقول:"... فأما كون الفاء والعين واوين فلم يجئ منه فَعل، لما يلزم فيه من الاعتلال، ولم يجئ منه اسم إلا "أول"، وسبب لهن

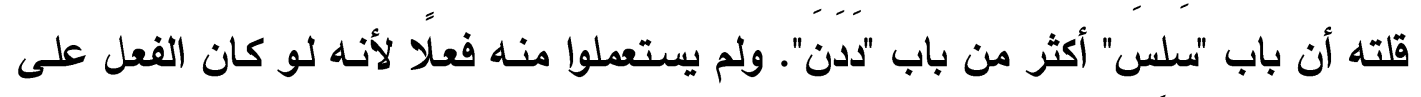

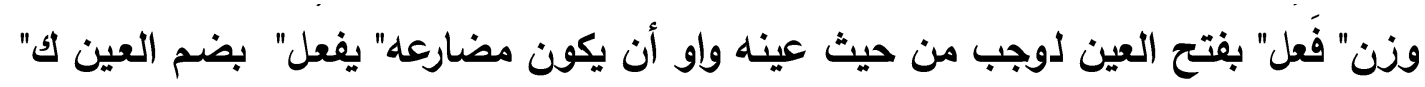

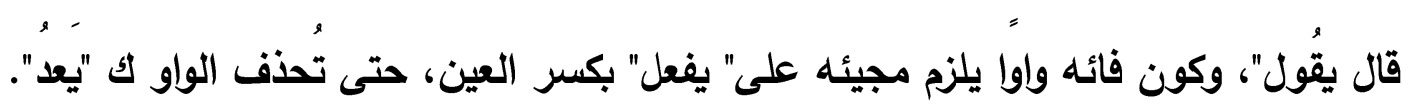
فلما كان ذلك يؤدي إلى التدافع رفض، مـع مـا فيه من ثقل الواوين. ولو كان على وزن لئن 


\section{د. حسن رمادي غانم نصر}

"فَعل" بضم العين لكان المضارع بضم العين، فكنت تقول" وال يوول" ' فيؤدي ذلك إلى اجتماع واوين وضمة، مع ياء المضارعة أيضا في حال الغيبة"'.

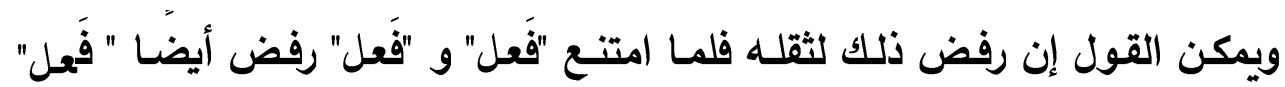

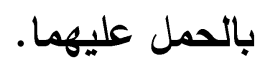

\section{ثانياء حمل حرض على حرض}

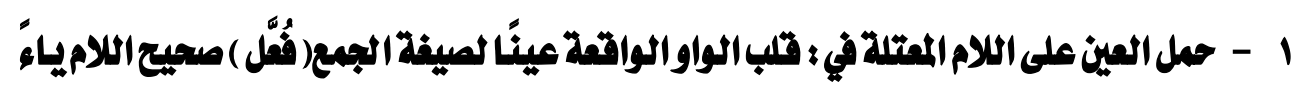

ذكر أبو الحسن أن الواو تقلب ياء في "فُعَل" ممـا كان فعله معتل العين بالواو

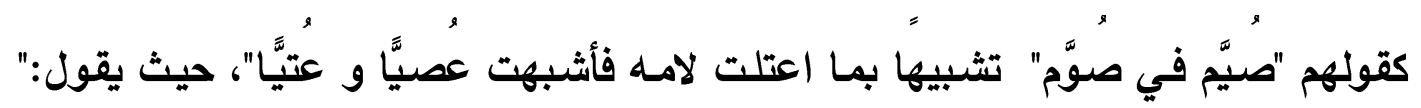

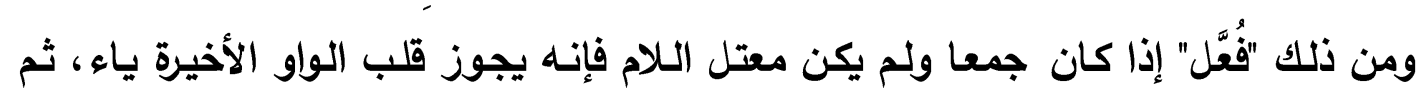
تقلب الواو الأولى يـاء، وتدغم الياء في الياء حملَّ على الللام.، وذلك نحو "صائم وصيَّم وصوَّم" ، و "جائع و جيَّع و جوَّع". قال الثاعرّم

$$
\text { عجَّلت طبختهَ لرهط جَيَّ }
$$$$
\text { ومغزَّض تَفْي المراجل تحت }
$$

$$
\begin{aligned}
& \text { ') ئْول في الهامش. } \\
& \text { " }
\end{aligned}
$$

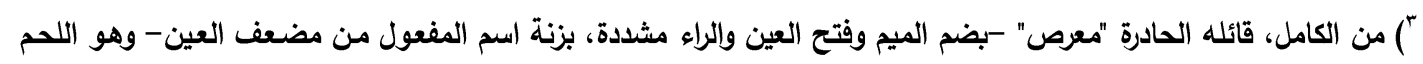

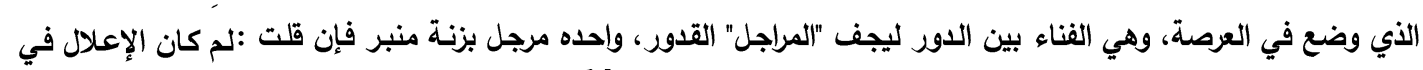

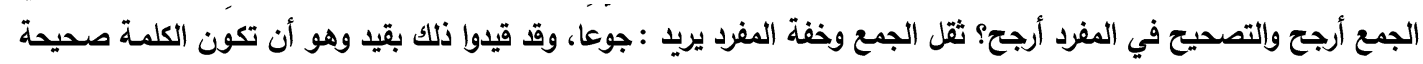

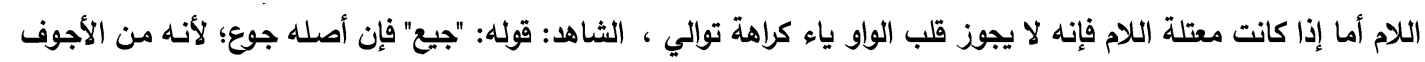

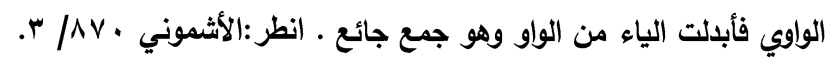


يريد" جوعا" والوجه ألا تقلب، وذلك أنك كنت تقول في جمـع عات: " عتي" فتقلب

في الجمع لا غير للعلة التي تذكر في موضعها' .

ويمكن القول إنه كثر الإعلال في "فُعَّ" جمع فاعل الذي عينه واو ، فيقال في نُوَّم

جمع نـائم :نَّنَم، وفي صوَّم جمع صـائم :صيَّم، وفي جوَّع جمع جائع :جيَّعَ ، والعلـة في القلب ثلاثة أمور :إحداها: إن اعتلال المفرد قد حمل الناطق إلى إعلال الجمـع من جهة العمل على سمتٍ واحد في تصاريفها المختلفة، ويمتنع الإعلال إذا كانت "فُعَّل" مفردا وليس

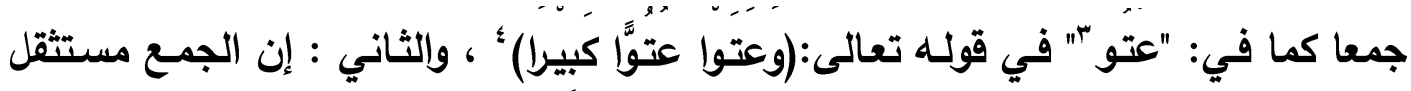
الأمر الأي يجعل الناطق يبحث عن التخفيف، والثالث: إن الواو وقعت بالقرب من الطرف ، واجتمع ثقل الضمة والواو.

كما يمكن تفسير ذلك باجتماع الواو -نصف صامت-مع الضمة القصيرة ، فاستثقل النطق فقلبت ياء ، فاجتمعت الياء -نصف الصامت- مـع الضمة والكواو فقلبت الواو ياء وأدغمت في الياء المنقلبة عن الواو فصارت "صيَّم".

\section{r- جواز بإغام البيم في ستة أحرف حملا على الشين}

تحمل الجيم على أختها الثين في جواز إدغامها في ستة أحرف رغم الاختلاف معها في المخرج لذا ذكر أبو الحسن أن البيان أفضل ،حيث يقول:" ويـاغم فيها من غير

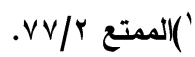

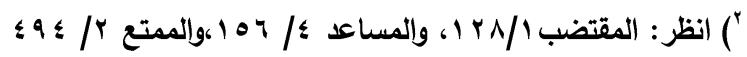

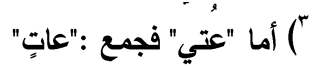

$$
\begin{aligned}
& \text { " الآية آَ من سورة الفرقان. }
\end{aligned}
$$




\section{د. حسن رمادي غانم نصر}

مخرجها ستة أحرف ، وهي: الطاء والدال والتاء والظظاء والذال والثاء، نحو" لم يربط جَّمَلَّ"

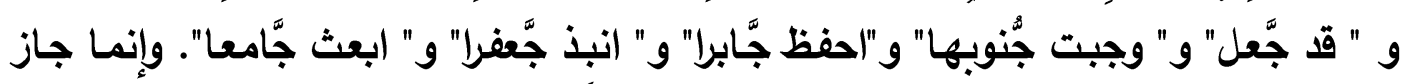

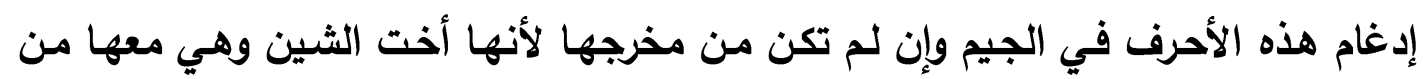

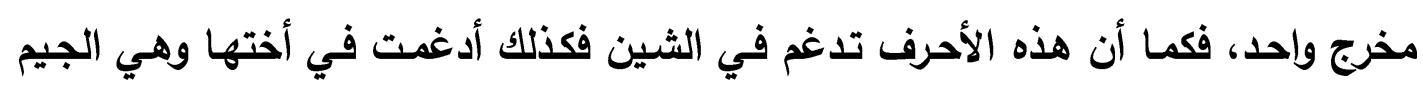

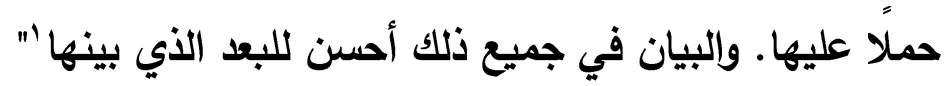

ويمكن القول إن الجيم تدغم في مثلها نحو :أخرج جابرا، ولم يلتقي في القرآن

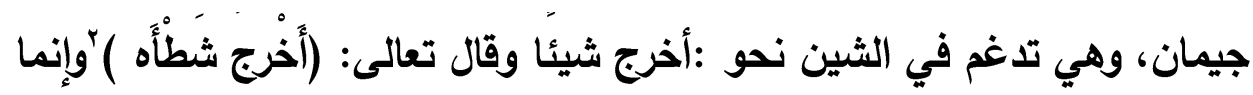
أدغمت الجيم في الثين لقربها منها مع كون الثين أفضل لأنها أزيد صفة، ولذلك لم تدغم الثين في الجيم ولا في غيرها عند النحويين "كما لها من الفضيلة بزيادة التفشي ،وقد

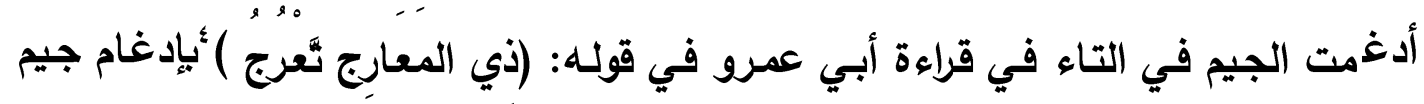

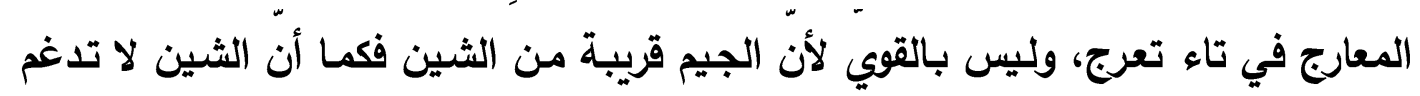
لفضيلتها فكذلك الجيم، وتدغم في الجيم :الطاء، والدال، والتاء، والظاء، والذال، والثاء، وإن لم تقاربها، لأن هذه الحروف من طرف اللّسان والثنايا، والجيم من وسط اللسان لكن أجريت الجيم مجرى الثين في إدغام هذه الحروف فيها، لأنها من مخرج واحد.

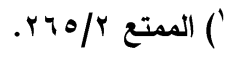

$$
\begin{aligned}
& \text { r) الآية و r من سورة الفتح. }
\end{aligned}
$$

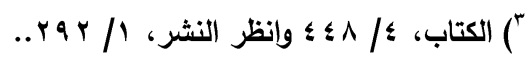

$$
\begin{aligned}
& \text { ؛ الآيتين r - ؛ من سورة المعارج }
\end{aligned}
$$


وأدغمـت هذه الحروف في الثـين لمـا في الثـين مـن التفثـي المتصـل بهـهـ

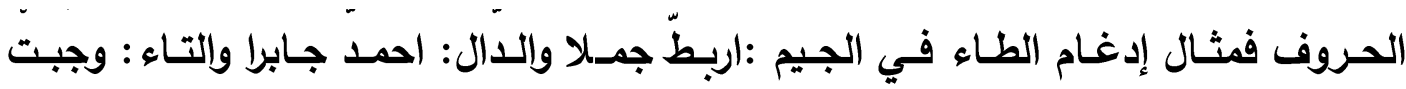

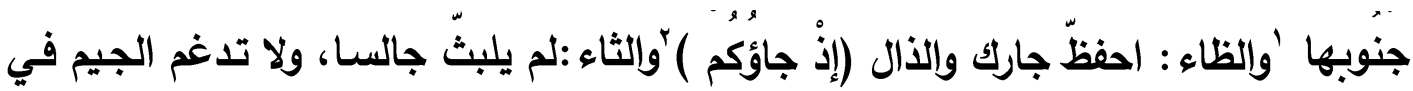
واحد من هذه الحروف الستة التي أدغمت فيها، كل ذلك لمشاركتها للشين، فأدغمت هذه الحروف فيها كما تدغم في الثين من غير عكس ذكر إدغام الثين”ّ

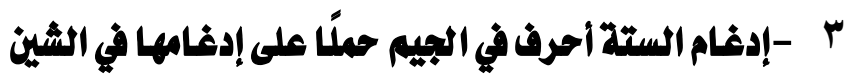

هنا نفس الحكم السابق بجواز الإدغام والبيان أفضل من الإدغام لو تقدمت الأحرف الستة على الجيم حمـلاً أيضًا على الثـين، يقول أبو الحسن: " ثم الطـاء واللدال والتـاء والظاء والذال والثاء ـ كل واحد منهنَّ يـاغم في الخمسة الباقية ، وتدغم الخمسة الباقية فيه. وتدغم أيضا هذه الستة في الضاد والجيم والثين والصاد واللزاي والسين، ولم يحفظ سييويه إدغامها في الجيم. ولا يدغم فيهنَّ من غيرهنَّ إلا الـلام ـ وسواء كان الأول منهمـا

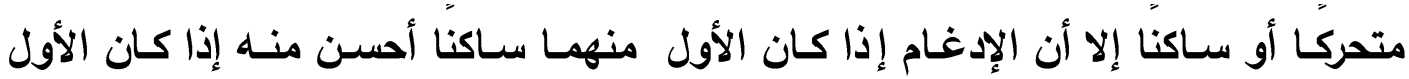
متحركًا لأنه يلزم فيه تغييران: أحدهما تغيير الإدغام، والآخر تغييز بإسكان الأول. وإنمـا جاز إدغامها فيما ذُكر لتقاربها في المخرج بعضها من بعض ولمقاربتها حروف الصفير في المخرج أيضًا كما بينَ في مخارج الحروف.

$$
\begin{aligned}
& \text { ') الآية بس من سورة الحج. } \\
& \text { r) الآية . } 1 \text { من سورة الأحزاب. } \\
& \text { r }
\end{aligned}
$$




\section{د. حسن رمادي غانم نصر}

وأمسا الضـاد والثين فإنهمـا - وإن لـم تقاربهمـا في المخرج- فإن التقارب بينهمـا وبينها من حيث لحقت الضاد باستطالتها، والثين بتفشيها مخرجها. والضاد أثبه بها من الثين لأن الضاد قد أثبهتها من وجه آخر ، وهو أنها مطبقة كما أن الطاء والظاء كذلك.

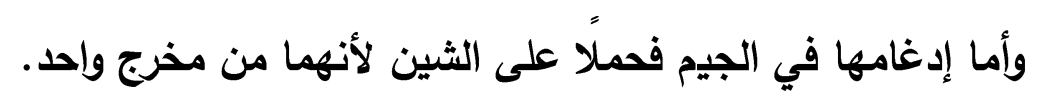

والإدغام في جميع مـا ذكر أحسن من البيان، والسبب في ذلك أن أصل الإدغام لحروف طرف اللسان والفم، بدليل أن حروف الحلق يدغم منها الأخخل في الأخرج لأنـه تقرب يذلك من حروف الفم، ولا يدغم الأخرج في الأدخل لأنه يبعد بذلك من حروف الفم، ويتمكَن في الحلق. وإنما كان الإدغام في حروف الفم وطرف اللسان أولى لكثرتها، ومـا كثر استدعى التخفيف. وأكثر حروف الفم من طرف اللسان لأن حروف الفم تسعة عشر ، منها اثنا عشر حرفًا من طرف اللسان، فلذلك حسن الإدغام في هذه الحروف.

فتبيين هذه الستة الأحرف إذا وقعت قبل الجيم أحسن من بيانها إذا وقعت قبل الثشين لأن إدغامها في الجيم بالحمل على إدغامها في الثشين، بـل لـم يحفظ سييويـ إدغامها في الجيم كما تقدم.

وتبيينها إذا وقعت قبل الثين احسن من تبيينها إذا وقعت قبل الضاد لأن الثين أبعد منها من الضاد ، لأن الثين أثبهتها من جهة واحدة وهو اتصالها بمخرجها بالتفشي 
الذي فيها-كما تقدم- والضاد أشبهتها من وجهين، وهما: اتصالها بها وبسبب الاستطالة، وشبهها بالطاء والظاء بسبب الإطباق كما ذُكر"' .

\section{ويمكن القول إنه:}

ا- إذا اجتمعت الطاء والجيم وكانت الطاء أولًا فإنها تدغم في الجيم، وهنا أثر

صوت الجيم في صوت الطاء فحولـه إلى جنسـه، وهذا أصل الإدغام أن يؤثر الثاني في الأول .والبيـان في مثل هذه البنى أحسن حفاظًا على إطباق الطـاء مـن جهـة، ولبعد المخرجين من جهة أخرى. r - جاز إدغام الدال في الثين، والثين أخت الجيم في المخرج ، فأدغمت في الجيم حملًا على إدغامها في الثين، على الرغم من أن الدال تتصف بالجهر وإلثدة، ولكن وقوع الدال ساكنة في نهاية مقطع أضعفها ، والبيان هنا أفضل لبعد المخرجين. ب- أثر صوت الجيم في صوت الثاء السـابق لله تأثيرا رجعيَّا ، وذلك لأن الجيم أقوى من الثاء لاتصافه بالجهر، والثاء يتصف بالهمس، زيادة على أن الثاء وقعت سـاكنة في نهاية مقطع مما زاد في ضعفها ، ووقعت الجيم في بداية مقطع فزادها قوة . ع - - إن الذال أخت الثاء في المخرج ، وقد أدغمت في الجيم وهي أقوى من الثاء لتمتعها بالجهر، فأحرى أن تدغم الثاء وهي الأضعف في الجيم حمـلا على أختها. ويجوز الإظهار لبعد المخرجين. 


\section{ثالثَا: حمل حركلة على حركة}

\section{1}

حمل أبو الحسن اللفيف المفروق على المثال والمعتل، وحمل التثنية والجمع على المفرد في عدم جواز الإدغام مما عينه ولامه ياءان، وهنا حمل النصب في امتناع الإدغام على الرفع والخفض ؛ ولذا يقول: "وأما ما عينه ولامـه يـاءان فإن العين منـه تجري مجرى حرف صحيح للعلة التي تقدمت أيضًا في باب "طويت". وأمـا الياء التي هي لام فتجري مجرى الياء فيمـا عينهله صحيحة نحو" رمسى" في جميع الأحكام سواء كان الاسم أو الفعل مزيدا أو غير مزيد، إلا ما يعرض في هذا الباب من الإدغام بسبب اجتماع المثلين. ذلك أن المثلين إذا اجتمعا في هذا النوع فلا يخلو من أن يكون الثاني سـاكنا أو متحركا، فإن كان

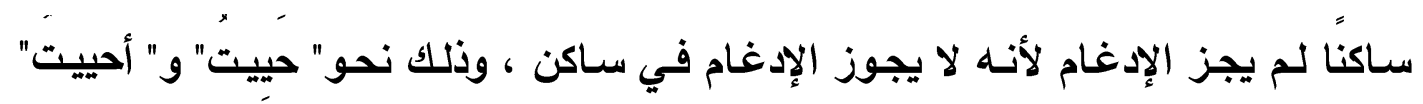
وأثباه ذلك. وإن كان الثاني متحركاً فلا يخلو من أن يكون ما قبله مفتوحَا أو غير مفتوح. فإن كان ما قبله غير مفتوح فلا تخلو الياء الثانية من أن تكون حركتها إعرابا أو بناء. فبإن كانـت الحركـة إعرابـا لـم تـدغم لأن الإعـراب عـارض يـزول في حـال الرفـع والخفض، فيسكن الحرف فلا يمكن الإدغام فيه، فيحمل النصب في امتناع الإدغام على الرفع والخفض، وذلك نحو" لن يحيي" و" أيت محييا" فلا تدغم في " هو يحيي" ولا في" هو محِيك"..وإن كانت الحركة بناء فلا يخلو من أن تكون متطرفة أو غير متطرفة، فِإن كانت

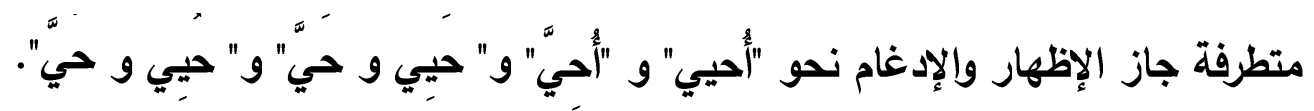


ويمكن القول إن الادغام يقع فيما حركته لازمـة' نحو: "حي" لأن فتح آخر الفعل الماضي لازم فلذلك حسن الإدغام في "حي" بخلاف ما لم تلزم حركته فإن الإدغام لا يجوز فيه، ويجب فكّه مثل مضارع المضاعف المذكور نحو :لن يحيى، ولن يستحيي ولن يحايي؛

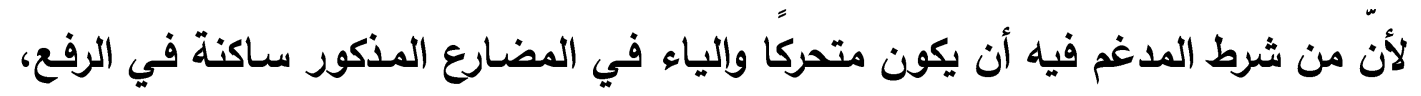

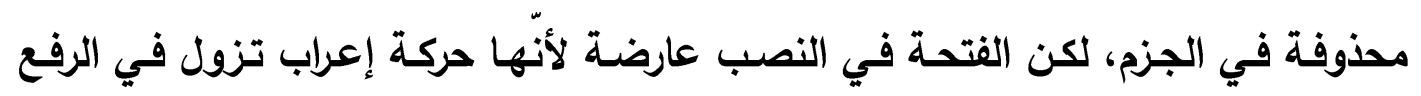
والجزم فلا اعتداد بها، لأن الحركة العارضة كالمعدومة بخلاف فتحة آخر الماضي فإنها فتحة لازمة ،فلذلك أدغم "حي" في الماضـي للحركة اللازمـة، ولم يدغم في المضارع لعدم اللزوم -

وإدغام مـا ذكر ليس بـلازم بـل يجوز فيه الإظهار لأنَ هذه اللّام قد تسكّن وقد تحذف في المضارع، فليست مما تلزمها الحركة في كل حال كالصحيح نحو :شدَ لأن الدآل

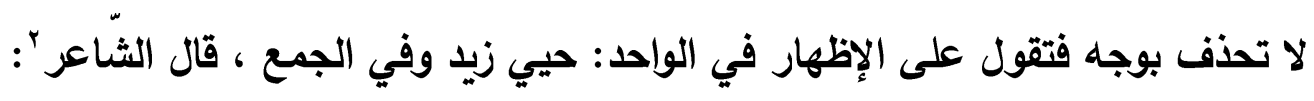

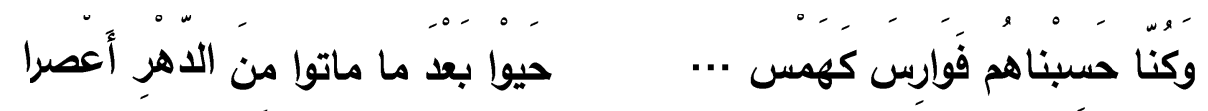

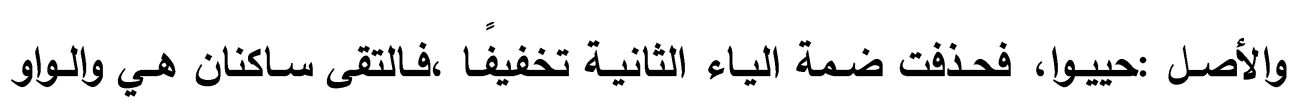
فحذفت الياء وضمت الياء الباقية وهي الأولى لأجل الواو بقي :حيوا.

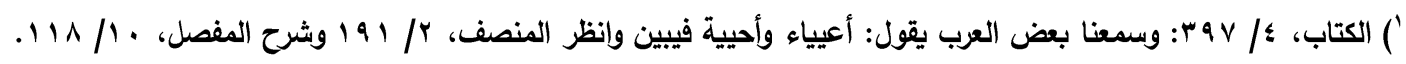

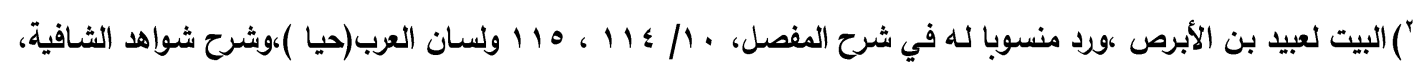

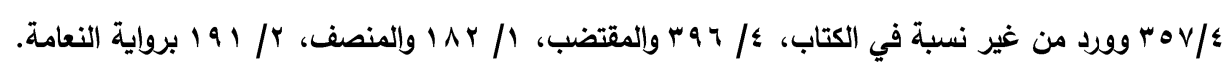


أما "استحييت "بياءين، فهي لغةُ أهل الحجاز على ما ينبفي من القياس، لأنهخح صححوا الياء الأولى، وهي عين الفعل، وأعَّوا الثانية، وهي لام الفعل، فقالوا" :استحيا،

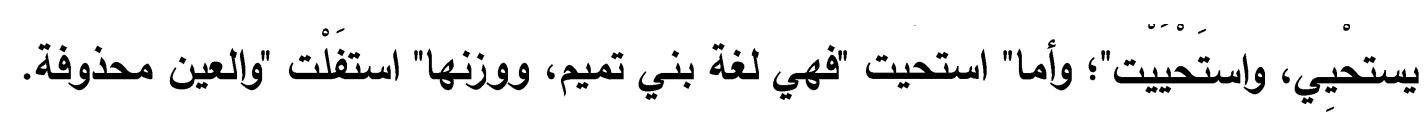

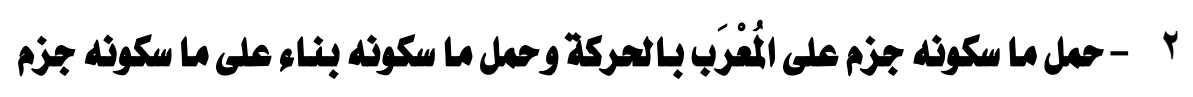

حمل أبو الحسن ما سكونه جزم على المعرب بالحركة لأنه معرب مثله، كما حمل ما سكونه بناء على ما سكونه جزم لأنه يثبهه حيث إدغام المثلين في كلمة والثاني حرف صحيح تصل إليه الحركة، ولذا يقول: "وإن اجتمعا في كلمة واحدة فلا يخلو الثاني من أن

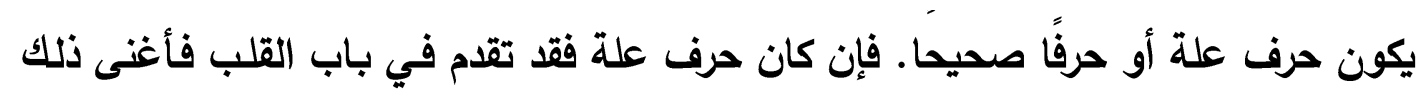

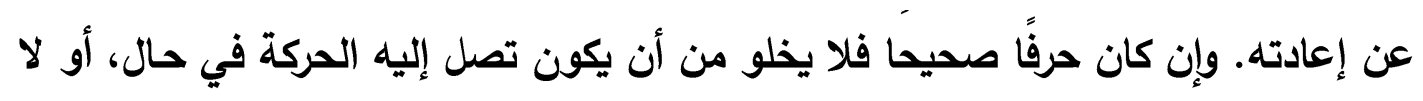
تصل : فإن وصلت إليه الحركة فإن أهل الحجاز لا يدغمون لأن الإدغام يؤدي إلى التقاء

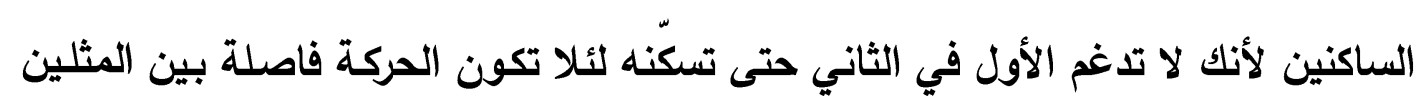
كما تقدم، وإثثاني ساكن فيجتمع ساكنان.

ويفسر أبو الحسن المسألة بقوله: فلما كان الإدغام يؤدي إلى ذلك رفضوه، وذلك

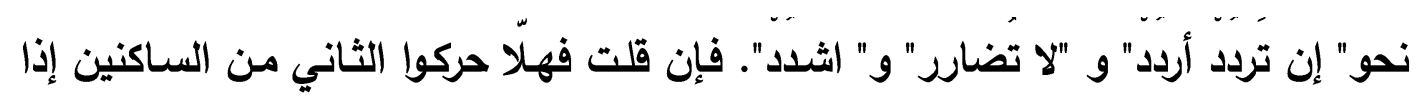
التقيا ، ثم أدغموا الأول فيه، فالجواب أن حركة التقاء الساكنين عارضة فلم يعتد بها كما لم يعتد بها في نحو( قِّ الليل)'

'الآية r من سورة المزمل.

(حولية كلية الآداب- جامعة بني سويف عدد خاص - يناير (·. ) ) 
ويزيد أبو الحسن الأمر وضوحا بضرب الأمثلة بقوله: ألا ترى أنهم لا يردون الواو المدذوفة من "قم" لالتقاء الساكنين، وإن كانت الميم قد تحركت لأن الحركة عارضـة. وأمـا غيرهم من العرب فيدغم ويعتد بالعارض لأن العرب قد تعتد بالعارض في بعض الأماكن،

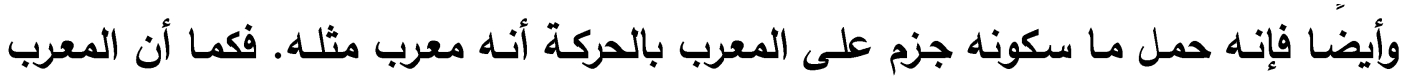
بالحركة تدغمه نحو" يفرُ" "فكنلك المعرب بالسكون، وحمل ما سكونه بناء على مـا سكونه جزم لأنه يثبهه؛ ألا ترى أن العرب قد تحذف له آخر الفعل في المعتل كما تحذفه للجزم،

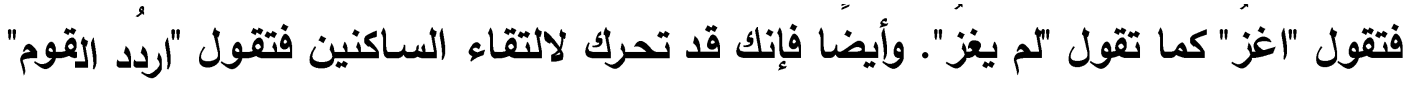
فصار بذلك يشبه المعرب بتعاقب الحركة والسكون على آخره كما أن المعرب كذلك في نحو" يضُرب" و" لم يضْرب" فلمـا أشبَه المعرب في ذلك حمل في الإدغام عليه'

ويمكن القول إن تحريك المجزوم بحمل مـا سكونه جزم على المعرب بالحركـة خثية اللبس مثل ذلك في ارتكاب اللّبس أنك تقول: لا تأكل السمك وتثرب اللّبن ،فتكسر الباء إذا أردت أن تنهاه عن أكل هذا وشرب هذا، على كل حال، فإن أردت أن تنهاه عن الجمع بينهما فتحت آخر تثرب، فلو حركوا المجزوم للقاء السـاكن بالفتح وقع لبس بين هذين النهيين، فلما خشوا اللّبس في هذا ونحوه حركوا المجزوم بحركة لا تعرب بها الأفعال، ثم حملوا ما سكونه وقف على ما سكونه جزم. 


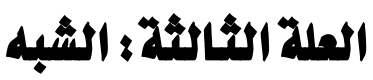

استعمال "الثببه" علة للقياس على الأصل النظري في العمل ، وهي علة موجبة يجب أن يسأل عنها ، وفكرة التثبيه بالمشبه فكرة تدل على إحاطة الأحكام بسياج من النهي العلل المفسرة لها يجعها في غاية الوثاقة ، وتعتبر تفسيرا لظاهرة الاشتراك بين الأصل والفرع. وكثير من الأحكام الصرفية مبنية على المثابهة، وقد ذكر سيبويه ذلك في مواضع كثيرة من كتابه'، منها قولـهـ ":وقد يشبهون الثيء بالثـيء كثيرا وليس

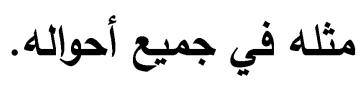

ويرتبط قولهم: "قد يعطى الثيء حكم ما أثبهه في معناه أو في لفظه أو فيهما" بعلة الثبه ، بدليل أن كل تطبيقات هذه القاعدة يرد في سياقاتها التعليل بعلة الثببه.ومن المسائل التي علل بها ابن عصفور المثابهة ما يأتي:

\section{-}

يقول أبو الحسن:" فإن قال قائل : ولأي شيء خصوا هذه الأحرف العشرة بالزيادة من بين حروف المعجم؟ فالجواب أن أمهات هذه الزوائد والذي هو زائد منها بحق الأصالة، الواو والياء والألف لكثرة دورها في الكلام واستعمالها، ألا ترى أنه لا تخلو كلمة منها أو من

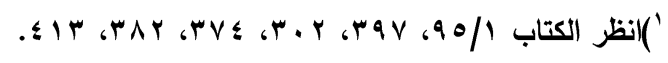

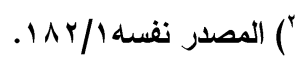

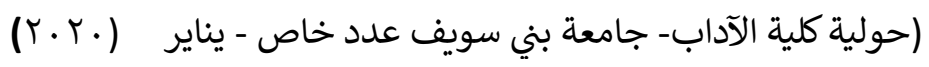


بعضها أعنـي الحركات: الضمة والكسرة والفتحة لأن الضمة بعض الواو ، والكسرة بعض الياء، والفتحة بعض الألف. ولما كانت أمهات الزوائد لذلك كانت أكثر الحروف زيادة. ويمكن القول إن أحق الحروف بالزيـادة أحرف اللين، وهي الألف، والياء، والكواو لسـهولة الإتيـان بها عنــ إثباع الحركات، ولأن كل كلمـة لا تخلو ممـا أخذ منها، وهـي الحركات الثلاث، والألف أخفها، فهي أحق بالزيادة من أختيها.

أما الهمزة والتاء والميم والنون فزيـدت لثبهها بحروف العلة :أمـا الهمزة فثبهها بحروف العلة من جهة كثرة تغييرها بالتسهيل والحنف والبدل. وأما التاء فأشبهت الواو من جهة تقارب مخرجيهما، ولذلك أُبدلت منها في مثل "تُراث" و " تُكأة" لأنهما من "ورثت" و"توكَأت". وأمـا الميم فمضـارعة للواو أيضًا مـن جهة تقاربهمـا في المخرج ، ومضـارعة لحروف العلة كلها من جهة الغنة التي فيها ، الثبيهة باللين الذي في حروف العلة لأن الغذة فضل صوتٍ في الحرف كما أن اللين كذلك. وأمـا النون فأشبهت أيضًا حروف العلة من جهة الغنة التي فيها. ولما كانت هذه الحروف قريبة الثبه من حروف العلة كانت تليها في كثرة الزيادة على ما يبين بعد إن شاء الله تعالى"' .وأما السين والـلام والههاء فإنها زيدات لثبهها بالحروف المشبهة بحروف العلة.

أما اللام فمشبهة للنون من حيث تسطيل في مخرجها حتى تلحق بمخرج النون على ما يبين في الإدغام. وأمـا السين فإنها تشبه التاء لهمسها وتقارب مخرجيهما. وأمـا 
الهاء فمشبهة للهمزة من جهة تقارب مخرجيهما لأنهما من حروف الحلق. ولمـا كانت هذه الحروف لـم تشبه حروف العلـة، بـل أشبهت المشبَّهة بها لـم تجئ مزيـدة إلا في ألفـاظ محفوظة وأماكن مخصوصة لا تتعداها ، فهي أقل الحروف زيادة لذلك"' .

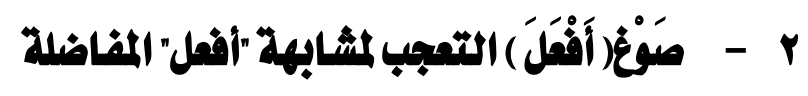

يجرى الإعلال بالنقل إذا كان حرف العلة عينًا لفعل مـاض أو أمر أو مضـارع، وقد لا تنقل حركة حرف العلة -عين الفعل- إلى الصحيح السـاكن قبلها، عندئذ يوجب تصحيح عين الفعل إذا كان فعل تعجب لحملهم فعل التعجبي على نظيره أفعل التفضيل من حيث الوزن والدلالة على المزيَّة، وليفصلوا بيته وبين المنصرف. يقول أبو الحسن: "ولا يصح"

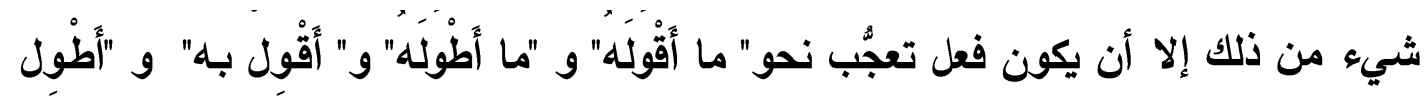
به" فإِنه يصح لشبهه ب "أَفْعل" التي للمفاضلة نحو" هو أَقْول منه" و" أطول"ك

ويمكن القول إن وجـه الثبه بينهما أنهما لا يبنيان إلا من شيء واحد، وأن فعل

التعجب فيه تفضيل لامتعجَّب منـه، كمـا أن "أفعل" يقتضـي التفضيل، وأن فعل التعجب لا مصدر لله ولا يتصرف، فصار بمنزلة الاسم لذلك.

كما يمكن القول كما قال سيبويهـ-- :إنهم أتموا ليفصلوا بينه وبين الفعل

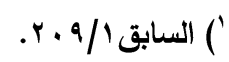

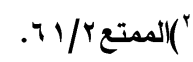

$$
\begin{aligned}
& \text { "ז|نظر الكتاب r/s ז"r. }
\end{aligned}
$$

( حولية كلية الآداب- جامعة بني سويف عدد خاص - يناير (·. ) 
المنصرف ،نحو: أقال، وأقام، ويتم في: ما أقوله وأبيعه لأن معناه معنى أفعل منك، وأفعل الناس، لأنك تفضله على من لم يجاوز أن لَزْمه قائل، وبائع، كما فضلت الأول على غيره وعلى الناس.

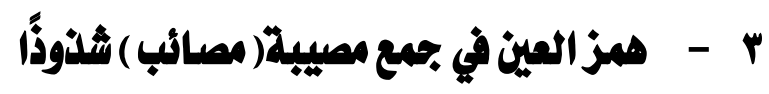

في جمع على وزن "مفاعل" أو" مفاعيل "حسب ما كانت عليه في المفرد)

لقلب الياء همزة يثترط أن تكون مدة زائدة في المفرد بعد ألف "مفاعل" ، لكنها صحت في " معيشة-معايش" ولم تقلب همزة لأنها ليست بمدة زائدة بل أصلية متحركة، لذا فهرد ذكر أبو الحسن أن الهمز في "مصائب" شاذّ لأن المد في الواحد أصلي، حيث يقول " فإن لم تقع في الجمع على حسب ما اعتلت عليه في المفرد ولا اكتنفت ألف الجمع حرفا علة

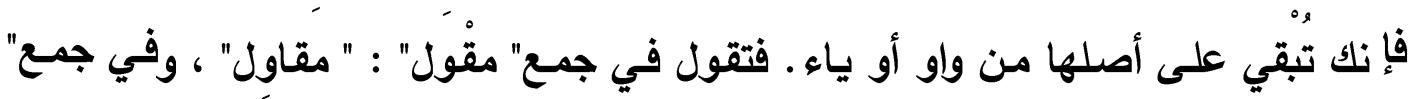
مقام" : "مقاوم"، وفي جمع "معيشـة" :"معايش" ، إلا لفظة واحدة شذت فيها العرب وهي "مصيبة" قـالوا في جمعها "مصـائب" فهمزوا العين. وكـان ينبغي أن يقـال في جمعها "مصاوب" لأنها من ذوات الواو.

ووجه إبدالهم من العين همزة أنهم شبهوا الياء في "مصيبة" لسكونها وإنكسار مـا قبلها بالياء الزائدة في مثل "صحيفة". فكما قالوا في "صحيفة": "صحائف" فكنلك قالوا في "مصيبة" "مصائب". 


\section{د. حسن رمادي غانم نصر}

ويمكن القول إن الذي سهل القلب في "مصيبة" شبه الأصلي بالزائد، أي أنهم

غلطوا وتوهموا فثبهوا ياء مصيبة وهي "مفْعلة" بالياء الزائدة في صحيفة، وهي "فَعيلة"

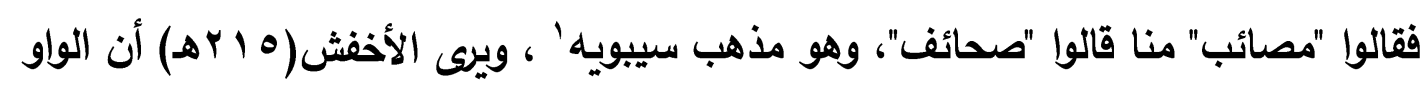
أعلت فقلبت همزة في مصائب لأنها أعلت في "مصيبة" ، ووصف الزجاج(1 استه) هذا الرأي بالرداءة لأنه يلزم أن يقال في "مقام" :"مقائم" ، وفي "معونة": "معائن" ، ، حيث يرى -

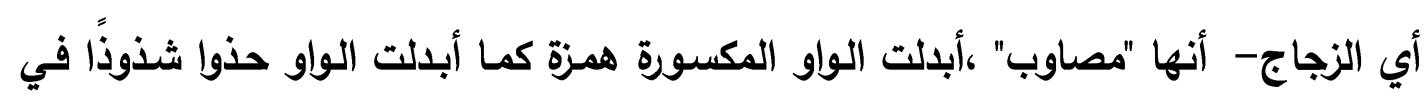
"أقائيم" جمع "أقوام" لما رأوا أن الواو المكسورة الواقعة فاء أبدلت همزة فقالوا في "وسادة":

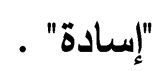

وإ لمرجح رأي سيبويه لأن مـا جاء على "فَعيلة" و "فعائلس" كثير الدوران في لسان العرب ، وكذلك كان السماع منهم، ومنى وجد السماع بطل القياس. ورجح ابن عصفور ما جاء به سيبويه لوجود النظير "أقائيم" .

ع - حذض مين الفعل المضاعف الثلاثي المكسور العين تشبيهًا بحذف العين إذا كانت

مرث ملة

ذكر أبو الحسن أن كَّلَّ من "ظلَّ" و "مسَّ" ممـا شدَّ من الفعل الثلاثي المكسور العين الذي عينه ولامه من جنس واحد، حيث يقول: "فإن كان الثاني من المثلين ساكنا

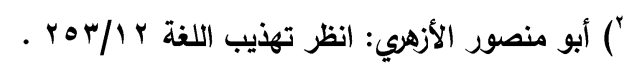

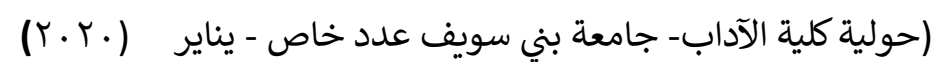


فالإظهار. ولا يجوز الإدغام لأن ذلك يؤدي إلى اجتماع الساكنين. وقد شذ العرب في شيء من ذلك فحذقوا أحد المثلين تخفيفًا لمَّا تعذر التخفيف بالإدغام، والذي يحفظ من ذلك " أحست" و" ظَلْت" و "مست" وسبب ذلك أنه لما كُره اجتماع المثلين فيها حذف الأول منهمـا تثبيها بالمعتل العين .وذلك أنك قد كنت تدغم قبل الإسناد للضمير فتقول "أحسَّ" و "مسَّ" و "ظلَّ". والإدغام ضرب من الاعتلال ،ألا ترى أنك تغيّر العين من أجل الإدغام بالإسكان كما تغيرها إذا كانت حرف علة. فكما تحذف العين إذا كانت حرف علة في نحو "قُمتِ" و "خفْت" و "بعت" كذلك حذفت هذه الألفاظ تشبيها بذلك"' .

ومما يبين ذلك أن العرب قد راعت هذا القدر من الثبه لأنهم يقولون "مسته" بكسر الميم، فينقلون حركة السين المحذوفة إلى مـا قبلها كما يفعلون في "خفت" .ألا ترى أن الأصل "خَوفْتَ" فنقلوا حركة الواو إلى الخاء، وحذفقا لالتقاء الساكنين على حسب مـا أُحكم في بابه.

وأما" ظَتِ" و "مست" في لغة من فتح الميم فحذفقا ولم ينقلوا فيهما الحركة تشبيها بهما ب "سَست" لما كان لا يستعمل لهما مضارع إذ حذفا كما لا يستعمل ل"ليس" مضارع،

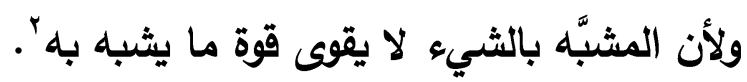




\section{د. حسن رمادي غانم نصر}

\section{ويمكن تفسير ذلك بالآتي؛}

ا- حذف أحد المثلين عند اتصـال التاء والنـون بالفعل فجـاء في ألفاظ، وهي أحست، ومست، وظلت 'الأصل أحست، ومسست '، وظللت، ونقل الفراء (V rهـ) ، وابن الأنباري(هـV هـ) همت والأصل :هممت، وحمل ذلك سيبويـه وغيره على الشذوذ، وأنـه لا ينقـاس فيمـا أشـبـه هـذه الأفعـال، وزعـم الفـراء أن ذلـك قيـاس مسـتمر فـي ردت ومـرت يريد :رددت ومررت، وزعم ابن مالك(TVY Tه) أن ذلك لغة مطردة لبني سليم؟ . r- يجوز كسر الظاء من ظلت، والميم من مست، وفتحهماّا.

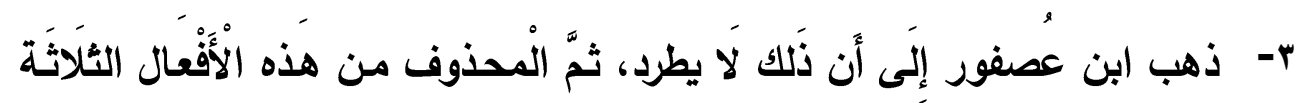

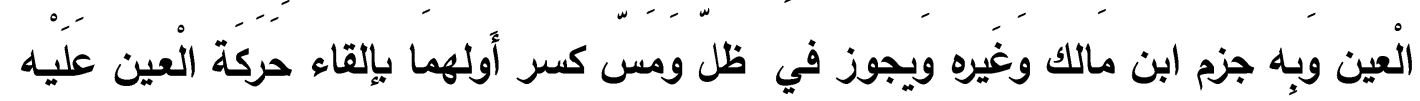

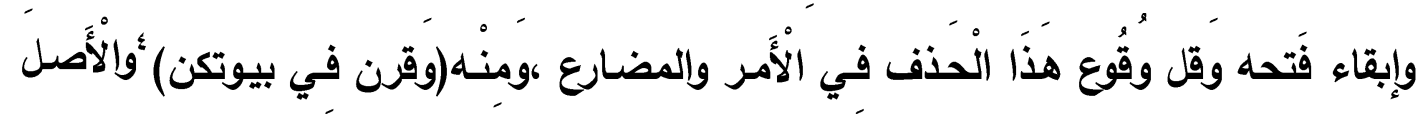
• ق قرن

ع- يجيز البحث حذف عين المضاعف الثلاثي المكسور العين أو المفتوح العين فيما سمع دون القياس عليه حتى لا تتداخل الأصول ولا يحدث تحريف للفعل.

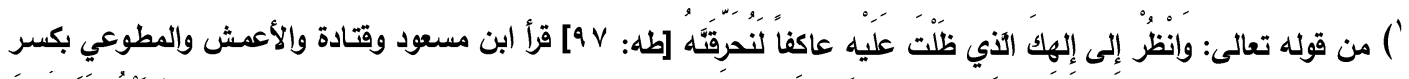

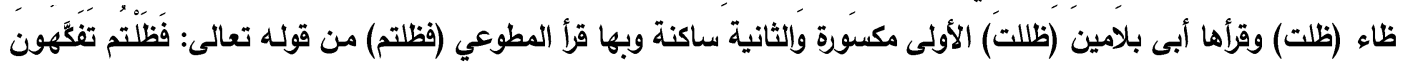

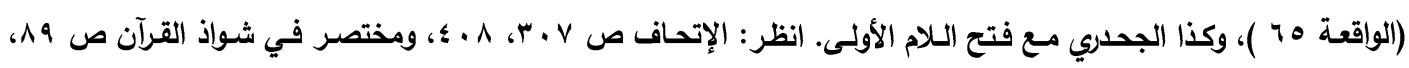

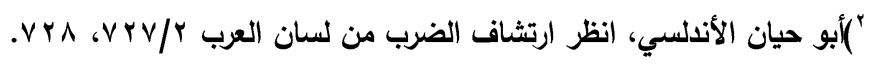

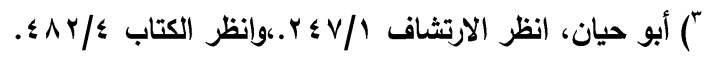

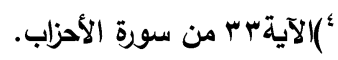

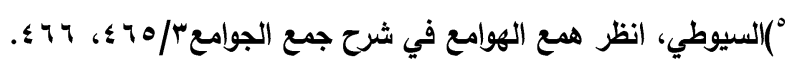




\section{ه- عدم حذف الواو في المضارع المبني للمجهول إذا وقعت فاء}

يقول أبو الحسن :"فإذا رددت الفعل إلى ما لم يسم فاعله لم تحذف الواو ، فقلت " يوعد". فإن قيل: ولم لم تحذف الواو وأنتم تزعمون أن الفعل المبني للمفعول مغيَّر من فعل الفاعل، ولذلك لم تد غم العرب الواو في الياء في " بويـع" و" سوير" وأمثالهمـا لأن الأصل"

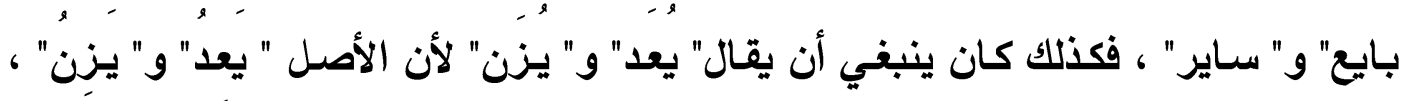
فالجواب أن كل فعل مضارع ثلاثي مبني للمفعول يأتي أبدا على وزن "يفعل" بضم حرف المضارعة وفتح الع ين، ولا ينكسر ذلك في شيء منهن فأشبه مضـارع "فعل" في أنـه يلوم

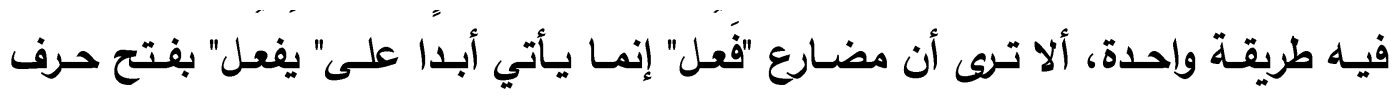
المضارعة وضم العين فحمل عليه ذلك. وأيضًا فإن العرب قد تعتد بالعارض ولا تلتفت إلى الأصل ، فيكون قول العرب "يوعد" من قبيل الاعتداد بالعارض فلذلك لم يحمل على فعل الفاعل. ويكون" سوير" من قبيل ترك الاعتداد بالعارض، فلذلك حمل على" ساير" فلم تحذف الواو منه كما تحذف من مضارع" فعل" "' . ويمكن القول إن الفعل المضارع وفعل الأمر إذا كانا من الأفعال التي ماضيها من نحو :وعد، حذفت فيهما الفاء وجوبـا، وذلك نحو :يعد وعد، ويزن وزن، ويرد ورد، لأنها من وعد ووزن وورد ، حذفت الواو في الأصل مـع الياء التي للمضـارعة استثقالا لوقوعها في فعل بين ياء مفتوحة وكسرة إذا قلت :يوعد. أمـا وقوعها في الفعل فهو ثقيل والاسم 


\section{د. حسن رمادي غانم نصر}

أخف منـه، ووقوعها بين الياء والكسرة لتجانسهما ومنافرة الواو لهمـا، واليـاء مفتوحة،

$$
\text { والفتحة من الألف، والألف قريبة من الياء'. }
$$

كذلك في المصدر :عدةَّ، حُذَفت الواو. فما كان مثَال (عدَة )ونحوه ممَّا وقعت فيه

$$
\begin{aligned}
& \text { الواو فاء حينئذٍ تحذَفَ في فاء الأمر، وفي فاء المضارع، وفي فاء } \\
& \text { المصدر، ويعوّض عنها في المصدر تاء في آخره. }
\end{aligned}
$$

أما "يوعَدَ" فلم تُحَْفَ الواو لكون حرف المضارعة ليس مفتوحَا، فلو كان مضموما

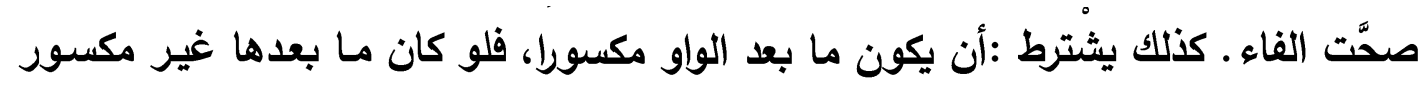

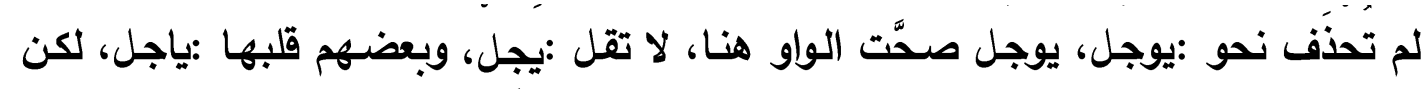

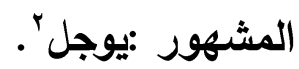

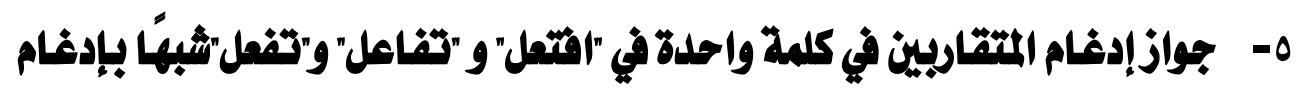

\section{المقاربين في كلمتين}

تبدل الدال من تاء الافتعال ومشتقاتها إبدالاً مطردا، يقول أبو الحسن:".....إلا أن يجتمع المتقاربان في "ا فتعل" أو" تفاعل" أو" تفعَّل" نحو" اختصم" و "تطيَّر" و "تطاير" فإنه يجوز الإدغام فيها، والسبب في ذلك ما ذكرناه في إدغام المثلين ، من أن التاء في هذه

$$
\begin{aligned}
& \text { ') شرح المفصل، · م/ 99ه - 11. }
\end{aligned}
$$

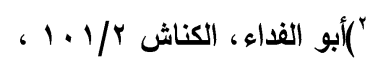

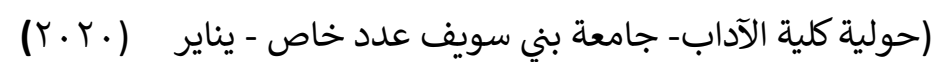


الأبنية الثلاثة تنزلت مما بعدها منزلة المنفصل ، لأنه لا يلزم أن يكون بعدها مثلها. وكذلك أيضًا لا يلزم أن يكون بعدها مقاربها، كما لا يلزم ذلك في الكلمتين.

فلما أثبه اجتماع المتقاربين فيها اجتماعهما في الكلمتين لم يلزم الإدغام كما لا يلزم ذلك في الكلمتين، فُمن التباس إدغام المتقاربين في هذه البنية بإدغام المثلين لأن الإظهار يبين الأصل كما كان ذلك في الكلمتين"' .فإذا أردت الإدغام قلبت أحد المتقاربين إلى جنس الآخر -على حسب ما أُحكم في الفصول المتقدمة- ثم أدغمت. فتقول في "تطيَّر" و" تدارأ" إذا أردت الإدغام:" اطيَّر " و "ادَّأرأ، فتقلب التاء حرفًا من جنس مـا بعدها وتسكنه بسبب الإدغام، ثم تدغم وتجتلب همزة الوصل، إذ لا يمكن الابتداء بالسـاكن. وتقول في "اختصم" إذا أردت الإدغام: "خصَّم" فتقلب التاء صادا وتسكنها بنقل حركتها إلى ما قبلها ثم تدغم. هذا في لغة من قال "قَّلّ" بفتح القاف والتاء. ومن قال "قهَّل" بفتح التاء وكسر القاف قال "خصَّم" بكسر الخاء وفتح الصاد. ومن قال "قّتّ" بكسرهما قال "خصم" بكسر الخاء والصاد، والعلة في ذلك كالعلة في "قتّل" وأمثالهــ ويمكن القول إنـه إذا كان فاء الفعل في "تَفَّل"، و"تَفَاعل " حرفًا يـغ في فيه التاء، جاز إدغامها وإظهارها .والحروف التي تدغم فيها التاء :التاء، والطاء، والدال، والظاء، والذال، والثاء، والصاد، والزاي، والسين، والضاد، والثين، والجيم، فاذا وقع شيء من هذه الحروف بعد التاء وآثرت الادغام، أدغمت التاء فيما بعدها. ولمـا أدغم أدخلت ألف الوصل 


\section{د. حسن رمادي غانم نصر}

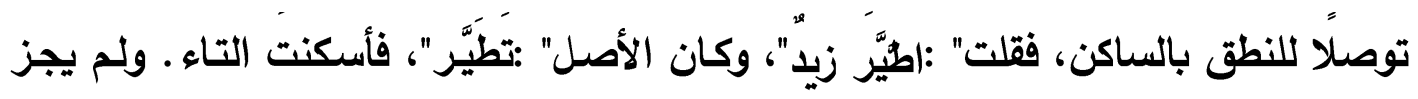

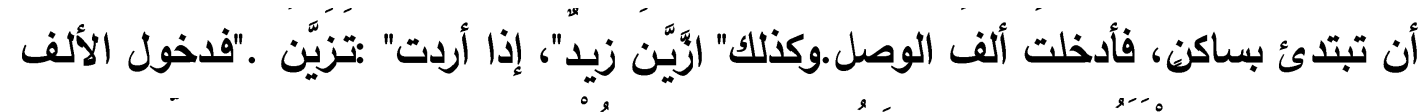

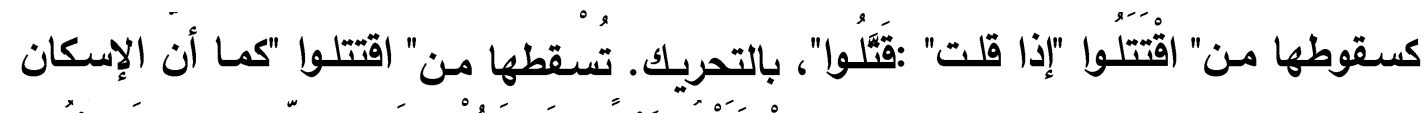

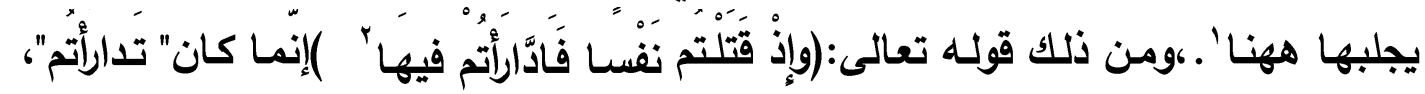

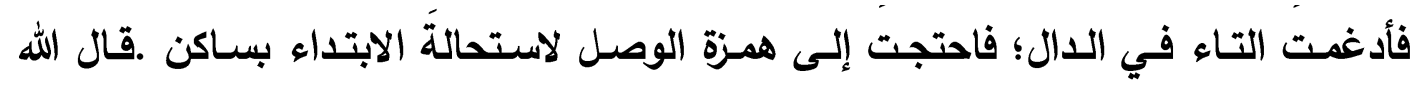

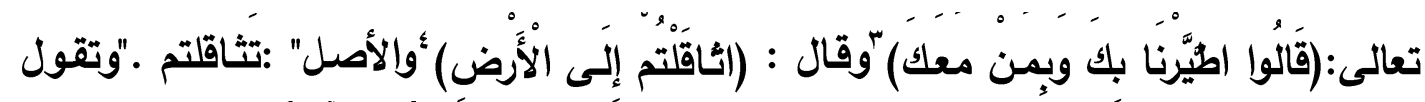

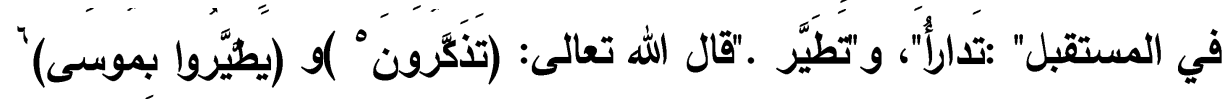

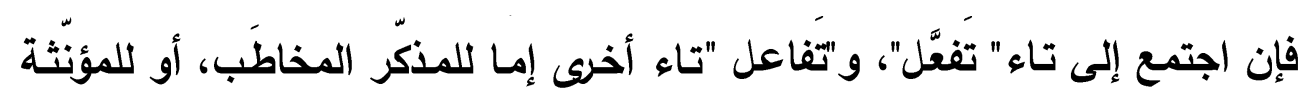

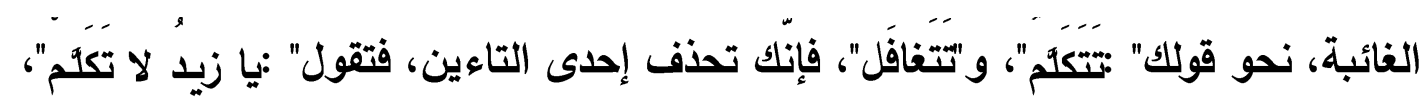
و"يا عمرو لا تَفَفَل"؛ لأنّه لما اجتمع المثلان، ثُقُل عليهم اجتماعَ المثلين، ولم يكن سبيل إلى الإدغام لما يؤدي إليه من سكون الأول. ولم يمكن الإتيانُ بالألف للوصل ، فوجب

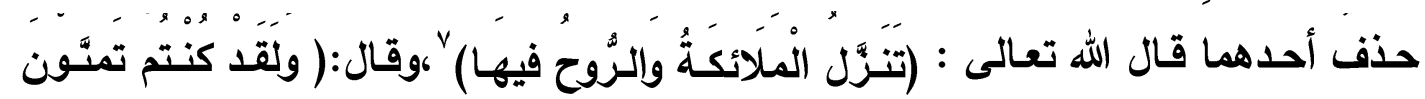

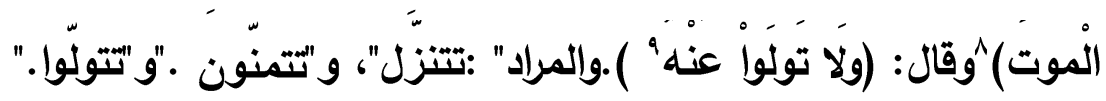

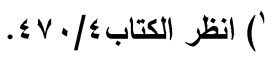

$$
\begin{aligned}
& \text { (البقرة: Vr. } \\
& \text { (النمل: V }
\end{aligned}
$$

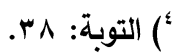

$$
\begin{aligned}
& \text { ") الأنعام: التوبه: }
\end{aligned}
$$

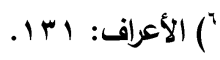

$$
\begin{aligned}
& \text { ) القدر: }
\end{aligned}
$$

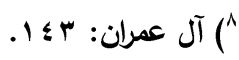

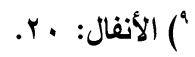


واختلف العلماء في المدذوفة، فذهب سيبويه 'والبصريون إلى أن" المدذوفة هي الثانيـة، وقال بعض الأصحاب :المدذوفة الأُولى، قالوا :ويجوز أن تكون الثانية.والحجةُ

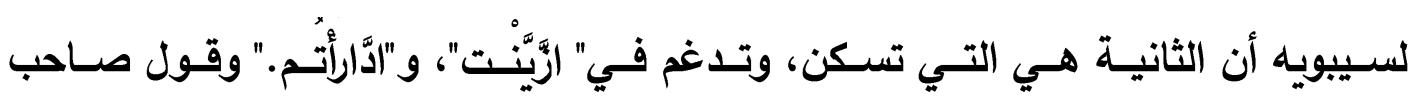

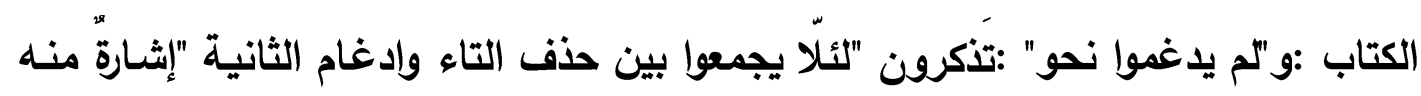
بأنه كان يسوغ الادغام لولا الحذف. وليس ذلك صحيحا؛ لأن هذا النوع من الإدغام لا يسوغ في المضارع لسكون الأول ودخول ألف الوصل، وذلك لا يجوز. ويمكن القول إنـا تجوز اللفات الثلاث نحو :تطاير، وتطير، فالإظهار، ويجوز الإدغام، فتجتلب همزة الوصل في الماضـي، والمضـارع والمصدر، والأمسر فتقول اطير واطاير، واطيروا واطايرا، وتقول في المضارع تطاير، وتطير.

\section{الملة الرابعة ؛ التقارب ( المجاذسة)}

قد تكون المجانسة سببا من أسباب العدول عن الأصل ، فموقع ما قد يتطلب حركة معينة بحسب القاعدة ، ولكن هذه الحركة المطلوبة قد تتنافر مع ما يجاورها، أو على الأقل لا تناسبه، ومن هنا يبدو السياق وقد اتخذ في مكان هذه الحركة حركة أخرى تتناسب مـع ما يجاورها.

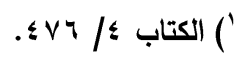

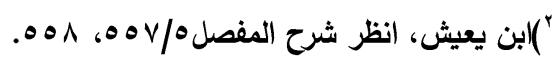
|r" 


\section{د. حسن رمادي غانم نصر}

\section{1 - تاب الواو الساكنة بعد كسرة ياءُ، وخلب الياء الساكنة بعد ضمة واواً}

ذكر أبو الحسن فيما يحرى مجرى ما قبله : قلب الواو الساكنة بعد كسرة ياء وقلب

الياء السـاكنة بعد ضمة واوا ، فيقول : "فإن كانت الواو سـاكنة بعد كسرة فإنها تقلب ياء نحو "ثيران" جمع "ثور" ، أصله" ثوران" فقلبت الواو ياء ـ وإن كاتت ساكنة بعد ضمة فإنها تقلب واوا ، وإن كانت بعيدة مـن الطرف نحو عوطَط' " لأنهم يقولـون "عاط يعيط " و"

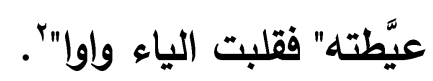
واستثنى أبو الحسن من ذلك:" فُعلَى" مما عينه ياء : - - فإن كانت اسـما قلبت الياء واوا نحو "طوبى" على القياس لأنها بعيدة عن الطرف.

- وإن كانت صفة قلبت الضمة كسرة لتصح الياء ،ومنه قوله تعالى : ( قسمة ضيزىى) "، وأصله "ضُيزى " على وزن "فُعلى "بضم الفاء.

ويمكن القول: إنـه لا يحفظ في الصفات "فعلى" يكسر الفاء ، بـل بضمها ، نحو "حبلى" ، وإنما قلبت الضمة كسرة لأنهم لم يعتدوا بألف التأنيث ، فجرت بذلك مجرى القرببة

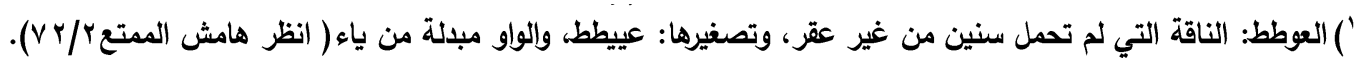

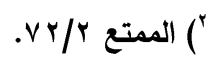

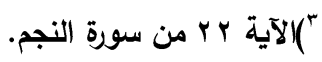


من الطرف .وهنا يلاحظ تعدد العلل فلم يقتصر الأمر على المناسبة بل تعداه إلى الحمل ، وهذا من ثراء العلل وترابطها وعلاقتها بالدلاية.

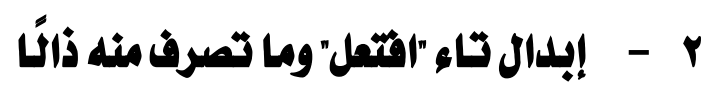

إذا وقعت الزاي والتاء متجاورتان داخل بنية واحدة على صيغة اقتعل أو إحدى مشتقاتها فإن تاء افتعل تقلب دالاً، ويعلل أبو الحسن هذا القلب بقولهـ: "وأما الدال فأبدلت مـن التاء والذال ، فأُبدلت من تـاء "(فتعل" باطراد إذا كانت زايـا، فتقول في "(فتعل" مـن

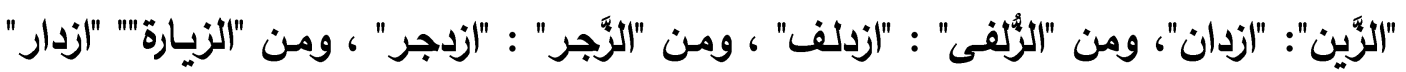
،والأصل:"ازتان" " ازتجر" " ازتلف" "ازتار".

فرفضوا الأصل وأبدلوا من التاء دالاً. والسبب في ذلك أن التزاي مجهورة والتاء مهموسة، والتاء شديدة والزاي رخوة، فتباعد مـا بين الزاي والتاء، فقربوا أحد الحرفين من الآخر ليقرب النطق بهما، فأبدلوا الدال من التاء لأنها أخت التاء في المخرج( والثدة)، وأخت الزاي في الجهر"' . ويمكن القول:

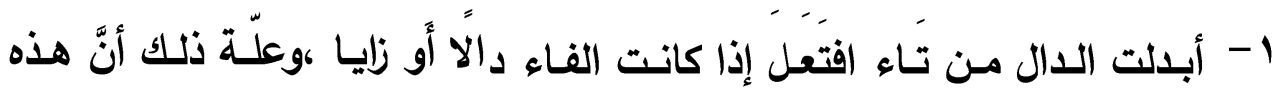

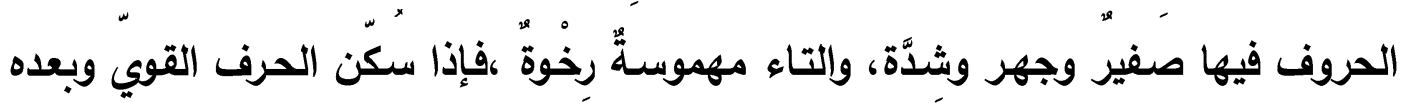
ضعيف كان في إخراج القوي بصفته وسكونه وإتباع الضعيف إياه بـلا فصل كلفة شديدة 


\section{د. حسن رمادي غانم نصر}

،فأُبل من التَّاء حرف يقْرب منها في المخرج ويقرب من الحرف الآخر في الصفة وذّلك هو الدَّال فإِنَّها من مخرج التّاء .

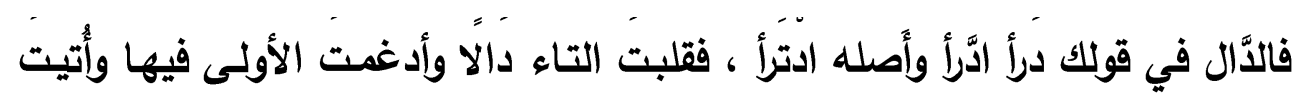
بهمزة الوصل لسكون الدَّال الأولى بسبب الإدغام ،ولا يجوز قلب الدَّال هنا تاء، وترك تاء الافتعال لئَكَ تبطل القوة التَي في الَّاَل.

ويمكن تفسير هذه الظاهرة بأن التاء أخت الدال في المخرج، كما أن الدال والززاي حرفان مجهوران، والتاء حرف مهموس، فأبدلوا من التاء دالاً ليقربوا بين الصوتين، وتتحقق بينهما المجانسة والتناسق الصوتي.

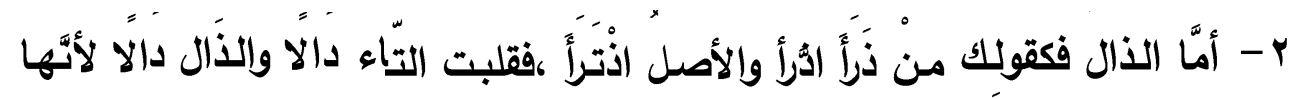

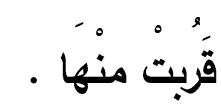

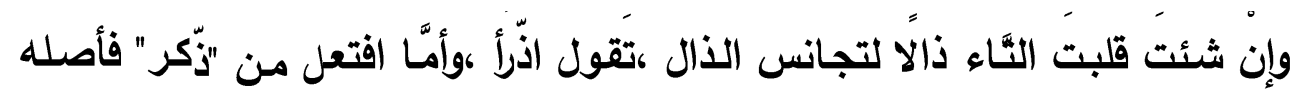

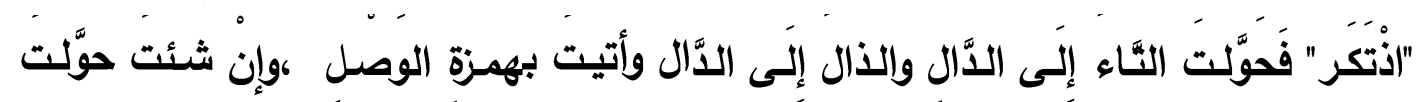

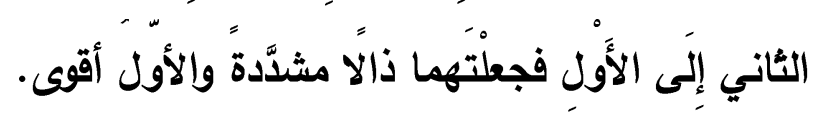
-....ت

أثثر صوت الأل المجهور في صوت التاء المهموس تأثيرا تقدميَّا فحوله إلى مقابلـه المجهور وهو صوت الدال لأن صوت الذال يتسم بالجهر فيؤثر على غيره مما جاوره من أصوات، وقد تحقق التماثل بين الصوتين المتجاورين في الجهر، فقل التنافر بينهما. 


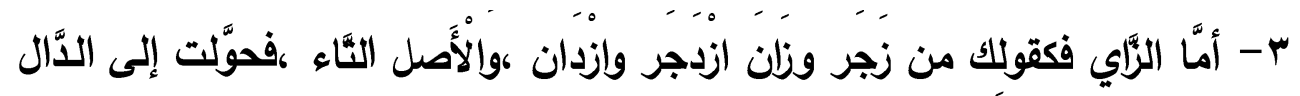

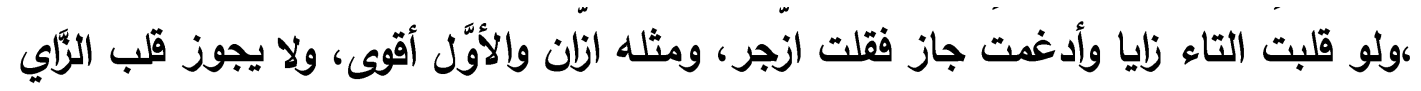
تاء لئَلَا يبطل ما في الزَّاي من زيادة الصفَات على الثَّاء. ….تj

إذا وقعت الزاي والتاء متجاورتان في صيغة افتعل أو إحدى مشتقاتها فإن تاء افتعل تقلب دالاً ، حيث أثر صوت الزاي المتسم بالجهر والصفير في صوت التاء المهموس تأثيرا تقدميًّا فحوله إلى مقابله المجهور ، والمقابل المجهور لصوت التاء هو صوت الدال لأن صوت الزاي المتسم بملامح قوة أكثر من صوت التاء ، فقد تحقق نوع من التماثل

$$
\text { الصوتي بين الصوتين في الجهر. }
$$

تبدل الصاد من السين إذا كان بعدها : القاف، الخاء، الطاء، الفين، يقول أبوالحسن:" وأمسا

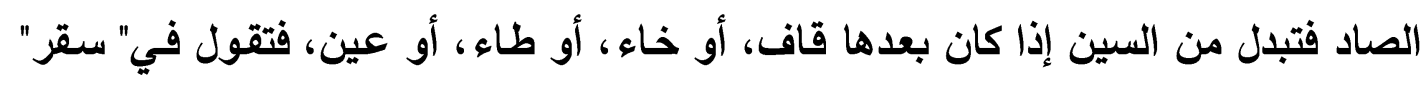

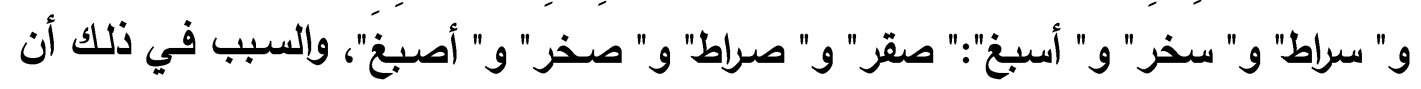
القاف والطاء وإذاء والغين حروف استعلاء، والسين حرف مستفل، فكرهوا الخروج من

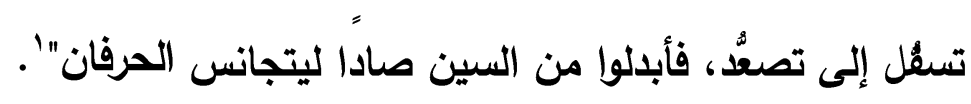




\section{د. حسن رمادي غانم نصر}

ويمكن القول إنه يجوز إبدال الصاد من السين متى وقع بعد السين غين أو خاء أو قاف أو طاء' ، لأن هذه الحروف مستعلية واللسين مهموسـة مستفلة، ولمـا كانت الصاد مستعلية وهي مـع ذلك مهموسـة وافقت هذه الأحرف في الاستعلاء ووافقت السين في الهمس والصفير والمخرج، فلذلك أبدلت منها. ‘ . س +ق،

أثثر الأصوات السابقة المفخمة في صوت السين المرقق تأثيرا رجعيَّا فحولته إلى صوت الصاد لأنه يثبه صوت السين في الهمس والاحتكاك،، وقريب من الأصوات المؤثرة في التفخيم، كما أن صـوت القـاف والطاء يتسـمان بالانفجـار، وصـوت الغين بالجهر ، والانفجار من ملامح القوة التي تمكن الصوت من التأثير في غيره من الأصوات. وذهب ابن عصفور إلى أن هذا الإبدال بقصد طلب الخفة الناجمة من التجانس بين الصوتين المتجاورين ليكون عملهم من موضع واحد.

\section{ع - - إبلدال الزاي من الصاد}

'فمثال السين التي بعدها الغين :سالغ -هو من البقر كالبازل من الإبل-، ويجوز "صالغ" بإبدال الصاد من السين.

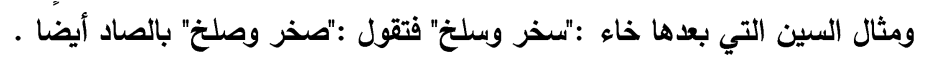

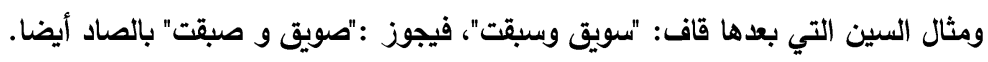

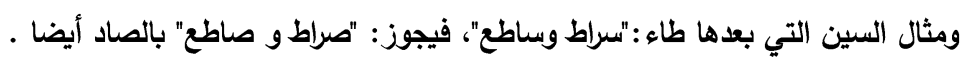

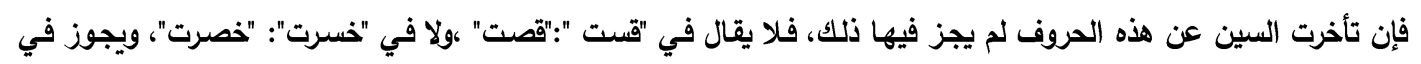

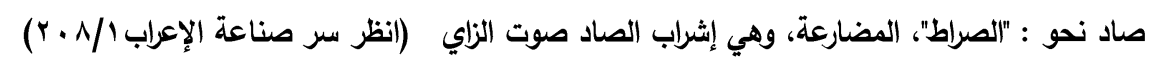

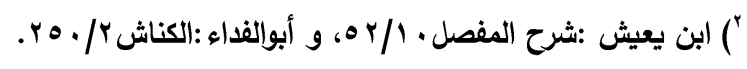

(حولية كلية الآداب- جامعة بني سويف عدد خاص - يناير (.r. ) 
يقول أبو الحسن: "تبدل الزاي من الصاد إذا كـان بعدها دال أو قاف، يقول أبو

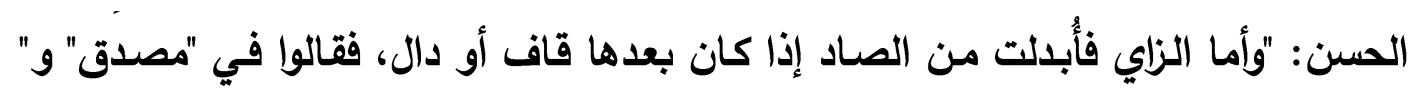
مصدوقة" : " مزّقَ" و" مزدوقة" ،وإنما تفعل ذلك كلب-قال '

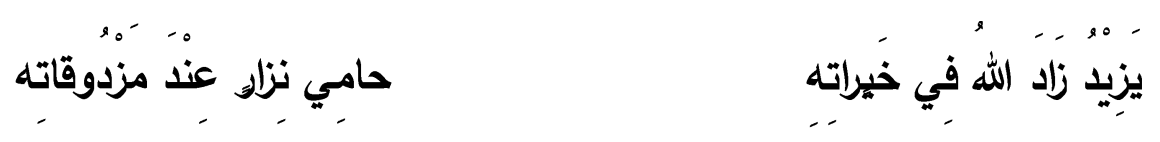

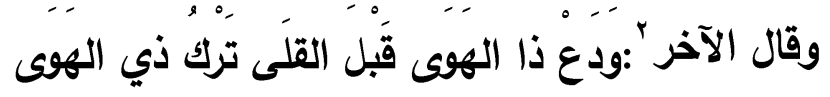

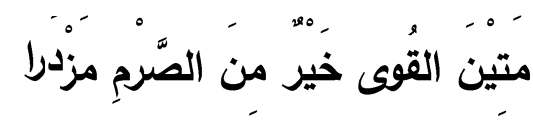

ويمكن القول إن إبدال الزاي من الصاد مطّردا جائزًا من كل صـاد سـاكنة بعدها دال

نحو: "فصدي" فيجوز فيه: "فزدي" بالزاي ويجوز إبقاء الصاد بحالها وهو أكثرّ"، ويجوز أن

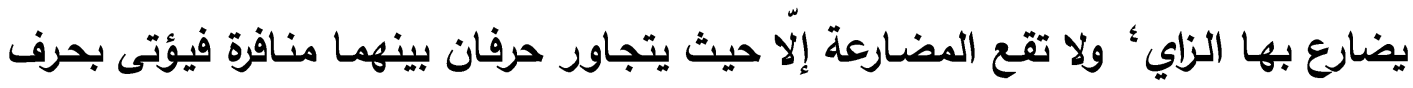
يصلح للتوسط بينهما ليزيل المنافرة، كما ينحى بالصاد نحو الزاي إذا تقدمت الصاد على الأل فتأتي بحرف مخرجه بين مخرج الصاد ومخرج الزاي، وليس كذلك السين في "يسدر" فلا يجوز فيها المضارعة ،فإن تحركت الصـاد امتـع إبدال الزاي منها ،لكن يجوز فيها

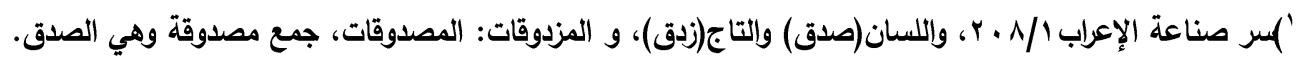

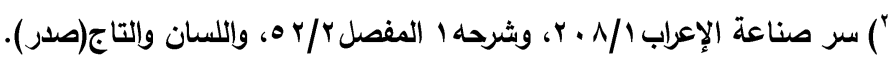
(n) ) معنى المضارعة أن يشرب الصاد شيئا من صوت الزاي .انظر اللسان (ض د ع) 


\section{د. حسن رمادي غانم نصر}

المضارعة فتقول في نحو "صدر عن كذا "بالصاد، وبمضارعة الصاد الزاي دون إبدال الصاد

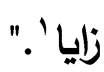

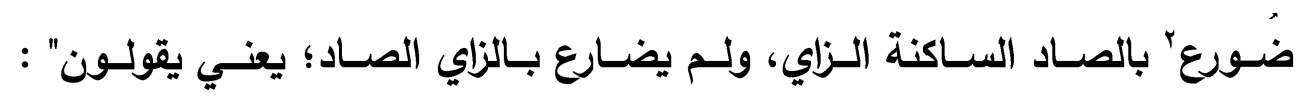

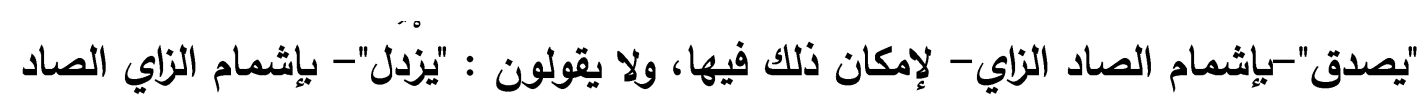

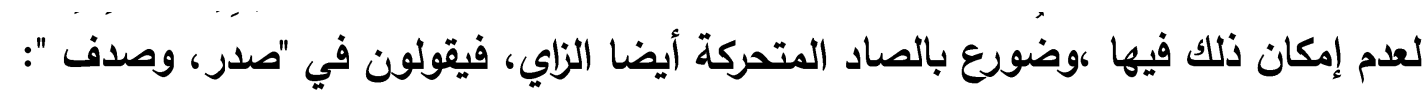
"صدر وصدف"، بإشمام الصاد الزاي، ولم يقولوا بإشمام الزاي الصاد .ولم يقولوا : "زدر"، بإبدال الزاي عن الصاد؛ لقوة الصاد بالحركة. فالمضارعة أكثر من الإبدال، وإلبيان أكثر من المضارعة والإبدال".

$$
د+j \leftarrow د+ص
$$

أثر صـوت الدال المتسم بـالجهر والانفجـار في صـوت الصـاد المتسـم بالإطباق والصفير تأثيرا رجعيًّ فحوله إلى صوت شبيه بصوتي الدال والصاد، وهو صوت الزاي، لأن صوت الزاي شبيه بصوت الصـاد في الصفير والمخرج، ويثبه صوت الدال في الجهر

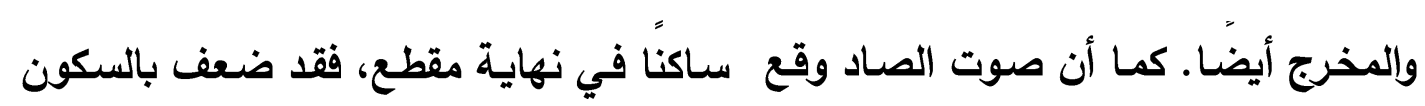
والموقعية، لكنه حافظ على ملمح الصفير فلذلك لم يقلب دالاً خالصة .

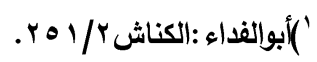

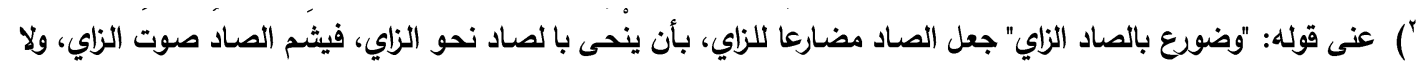

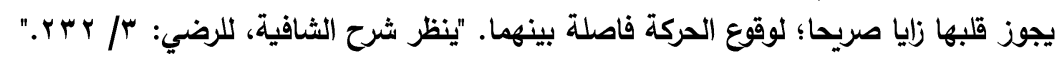

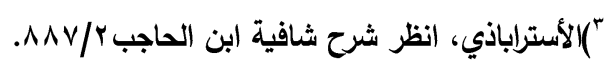

(حولية كلية الآداب- جامعة بني سويف عدد خاص - يناير (·. ) ) 


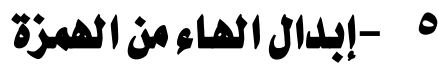

يتفق أبو الحسن مع سيبويه وابن جني في إبدال الهاء من الهمزة دو، أن يعلل:" وأما الهاء فأبدلت من خمسة أحرف ، هي: الهمزة، والألف، والياء، والثواو والتاء. فأبدلت من الهمزة في "إيَّاك" فقالوا "هيَّك" ـ أنثثد أبو الحسن " .

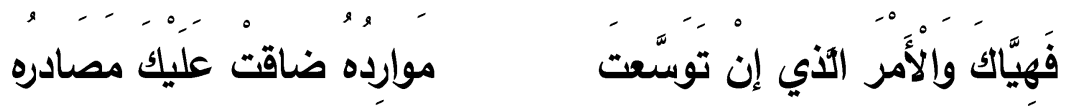
ويقال أيضًا "أيَّاك" و "هيَّك" بالفتح، و طيئ تبدل همزة "إنْ" الثرطية هاء، فتقول" هات

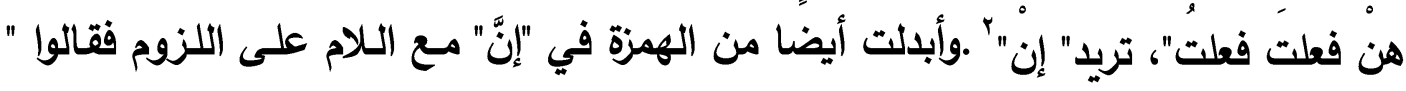

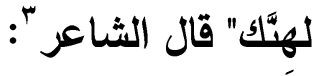

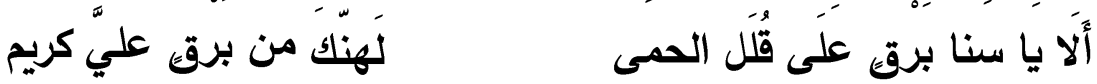

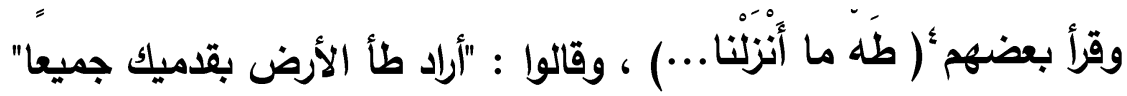
لأن النبّيّ-صلى الله عليه وسلم- كان يرفع إحدى رجايه في صلاته. وقالوا "أيا" و" هيا" في النداء، والهاء بدل من الهمزة لأن" أيا" أكثر من " هيا" ـ قال:

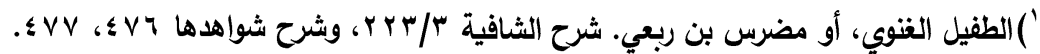
r

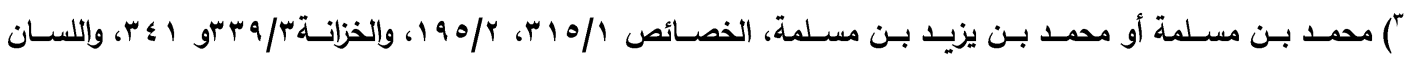

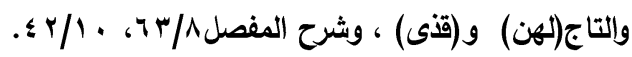

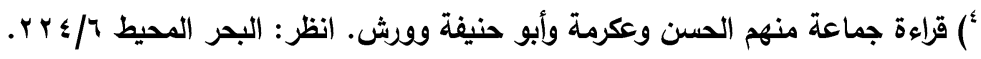




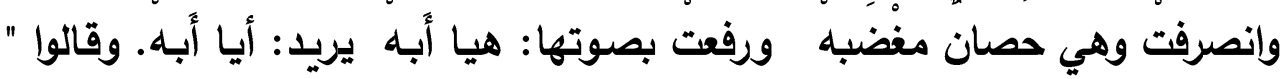

هما والله لقد كان كذا وكذا" يريدون: أما والله لقد كان كذا وكذا".'

ويمكن القول إن سبب إبدال الهاء من الهمزة يعود إلى طلب الخفة، فالهمزة صوت

ثقيل، وهو صوت انفجاري ليس بمهموس ولا مجهور، فأبدلوا منها الهاء لأنها صوت خفيف مهموس ،كما أن كلا الصوتين من مخرج واحد وهو المخرج الحنجري، إلا أن الهمزة لهنية أخرج من الهمزة فأبدلوا الأدخل إلى الأخرج وهو الأفضل.

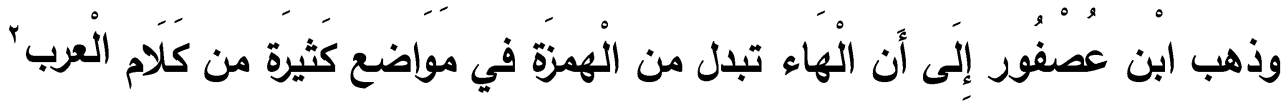

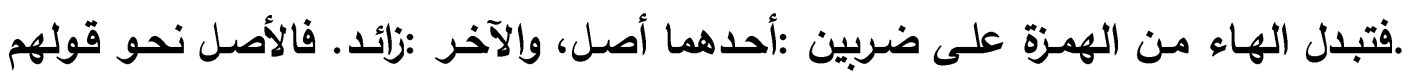
في" إياك" :"هيّاك " يقول" أياك "بفتح الهمزة، ثم يبدل الهاء منها وهي مفتوحة أيضًا، فِيقول" هياك "قال: وطيئ تقول" :هن فَعَل فَعلتُ "يريدون" إن ". فإبدال الهمزة من الهاء إبدال قياسي، وهما من مخرج واحد. وكونهما من مخرج واحد جدير بأن يقوي هذا الإبدال ويؤكده.قال الصيمري( · . بهـ) :" قلبت الهاء هزة، لأنها من مخرج الهاء، وهي أقوى منها في الصوت” . 
ويمكن تفسير هذا البدل بأن الهاء متحدة المخرج مع الهمزة ،فضلًا عن أن الناطق أراد أن يقفل المقطع الطويل بصوت قوي مثل الهمزة، إضافة إلى أن الهاء وقعت ساكنة في نهاية مقطع، والصوت الذي يقع في نهاية مقطع يكون عرضة للحذف وإتتأثر.

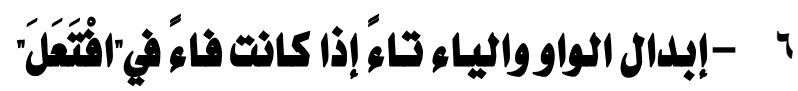

يقول أبو الحسن :"إذا كـان فـاء "|فتعل" ومـا تصـرف منـه واوا وجب قلبها تـاء وإدغامها في التاء التي بعدها ، يقول أبو الحسن :" إذا كانت فاؤه واوا نحو "انَّد" و" اتزن"

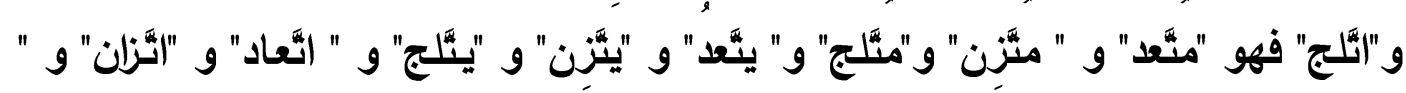

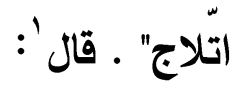

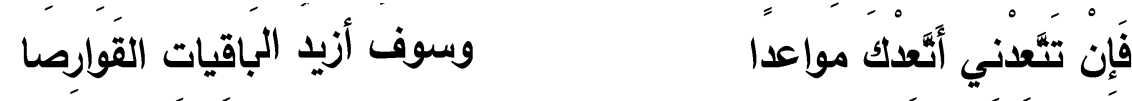

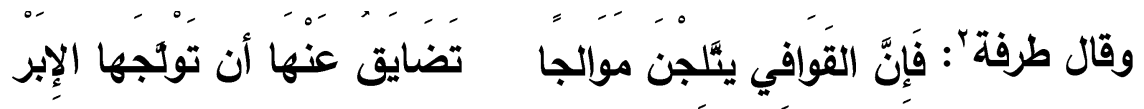

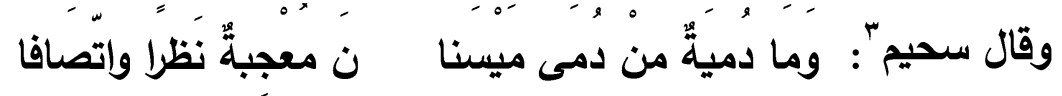

والسبب في قلب الواو في ذلك تاء أنهم لو لم يفعلوا ذلك لوجب أن يقلبوها ياء إذا

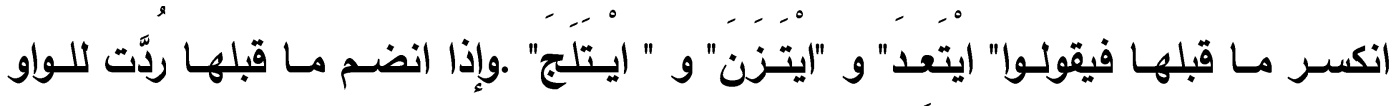

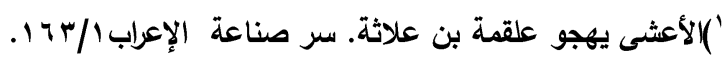
"اله صناعة الإعراب /

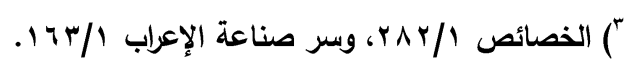




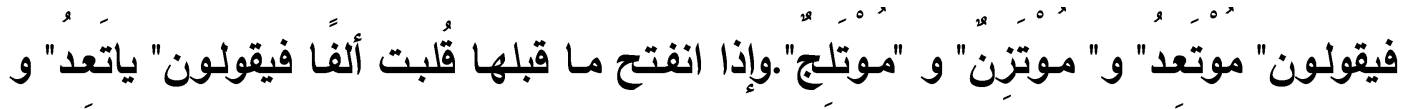

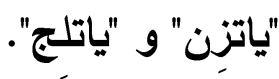

فأبدلوا منها التاء لأنها حرف جلْد لا يتغير لما قبله، وهي مـع ذلك قريبة المخرج

من الواو لأنها من أصول الثنايا ، والواو من الثفة. ومن العرب من يجريها على القلب ولا

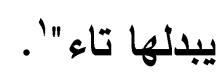

"إذا بنيت افتعل من المعتل بالواو والياء، نحو :وعد ويسر، قلت :اتّعد وإتسرر،

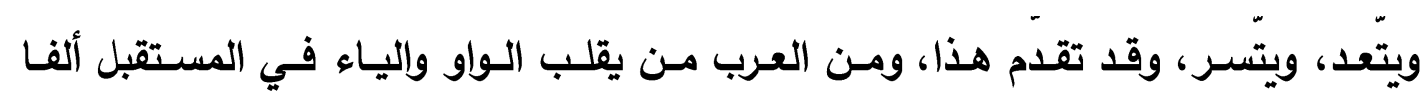
فيقول :ياتعد، وياتسر ‘، وياءس، ويابس " ومنهم من لا يقلبها" ؛ ويمكن القول: قلبت الواو تاء لضعف الواو وتلاعب الحركات بها، فقد تقع بعد

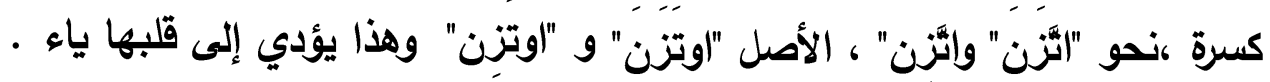

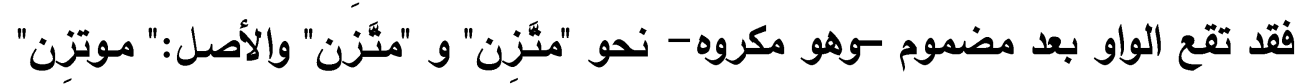
و "موتَنْ"، لذا أبدلوا مكانها حرفًا أجلد وصارت تابعة لما بعدها.

$$
\begin{aligned}
& \text { 'المتع / / }
\end{aligned}
$$

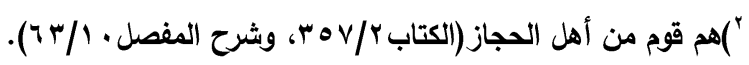

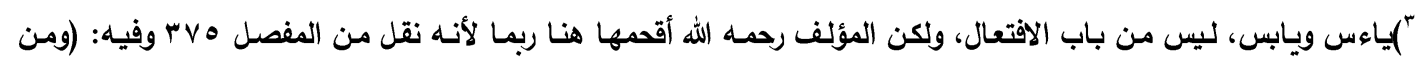

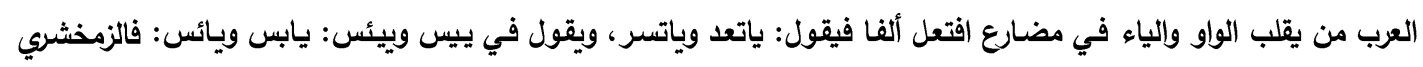

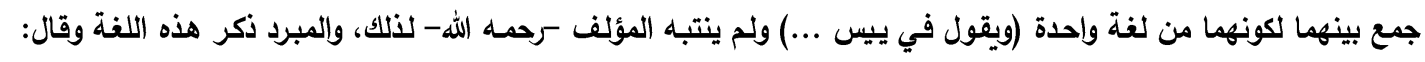

$$
\begin{aligned}
& \text { (وهذا ردئ جذا): المقتضب / / ب هو) }
\end{aligned}
$$

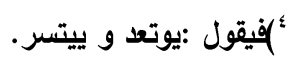




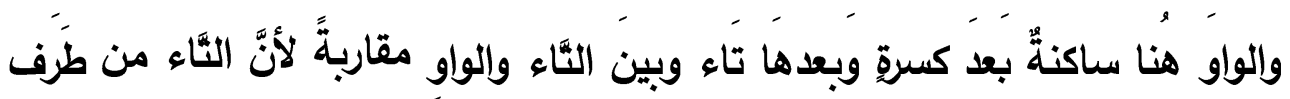

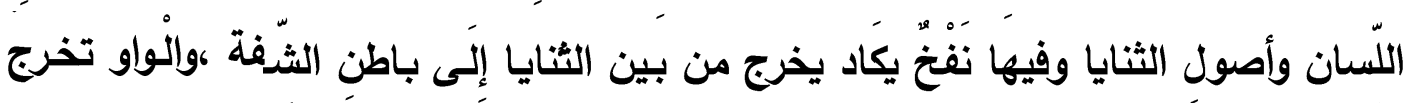

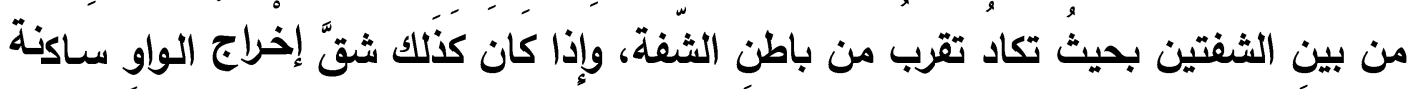

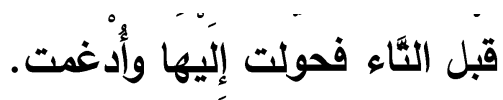

$$
\text { و+ ت ؟ تّ. نصف حركة+ انفجاري ـ انفجاري ضعيف }
$$

إذا وردت الواو بوصفها نصف حركة متجاورة مع التاء في صيغة "|فتعل" أو إحدى مشتقاتها فإن صوت الواو يتأثر بصوت التاء المجاورة تأثرا رجعيًّا فينقلب إلى تاء ، ثم تجرى عملية الإدغام، ويعود السبب في حدوث هذا التأثر الصوتي إلى أن صوت الواو يتسم بالقصر وقلة الوضوح السمعي إذا ما قيس بغيره من الحركات، أضف إلى ذلك وقوع صوت الواو ساكنا في نهاية مقطع، ووقوع صوت الواو تحت تأثير صوت التاء الانفجاري. والياء توافق الواو إن وقعت موقعها في "|فتعل" وما تصرف منه من حيث قلبها تاء وإدغامها في التاء التي بعدها، نحو "انَّر .... واطرد قلب الياء تاء تثبيها لها بالواو لأنها أختها في الاعتلال ، وفي موضعها حيث كانت فاء، وضعفت كضعفها.

\section{|إبلدال الطاء من تاء "اقتعل" - V}

تبلال الطاء من التاء في افتعل ومشتقاتها إذا كانت فاء افتعل صادا أو ضـادا أو طاء أو ظاء، يقول أبو الحسن: "وأما الطاء فأبدلت من التاء ، لا غير. أبّلت باطراد البتَّة، ولا يجوز غير ذلك، من تاء "|فتعل" إذا كانت الفاء صـادا، أو ضـادا، أو طاء، أو ظاء. 
فتقول في افتعل من: الصبر "اصطبر" ، ومن الضرب: "اضطرب" ، ومن الظهر : "اظطهر"، ومن الطرد :" اطرّد" فتدغم لأنك لما أبدلت التاء طاء اجتمع لك مثلان الأول منهما ساكن،

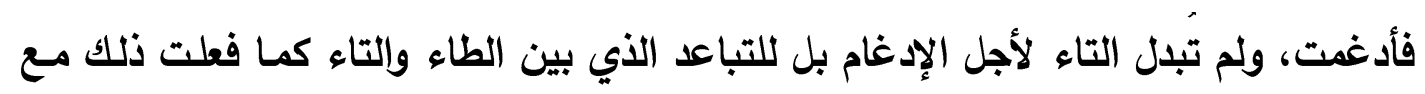

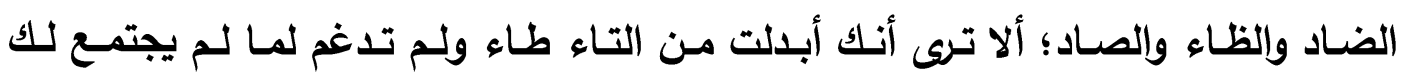
مثلان' .والتباعد الذي بين التاء وبين هذه الحروف أن التاء منفتحة منسفلة، وهذه الحروف مطبقة مستعلية، فأبدلوا من التاء أختها في المخرج، وأخت هذه الحروف في الاستعلاء والإطباق، وهي الطاء.

وأبدلت، بغير اطراد، من تاء الضمير بعد الطاء والصاد فقالوا:"فَحْطُ" و "خَبَطُ" يريدون" فحصت" و "خبطت" والأكثر التاء. والعلة في الإبدال كالعلة في "(فتعل" من التباعد الذي ذكرنا بين التاء وبين الصاد

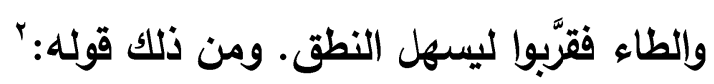

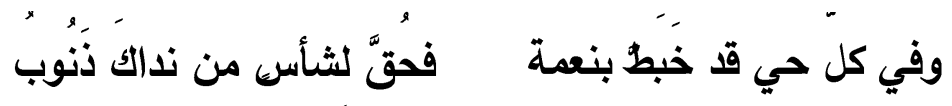
رواه أبو علي عن أبي بكر عن أبي العباس: "خَبُ" على إبدال الطاء من التاء" ". ويمكن القول إذا كَانَت فاء افتعل حرف إطباق -وحروف الإطباق أربعةٌ الصَّاد

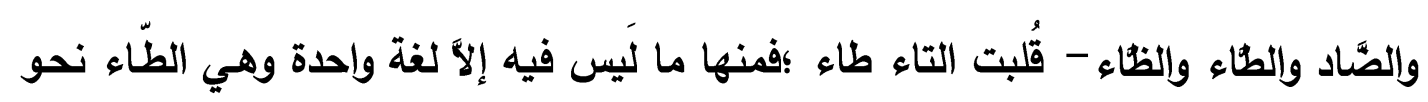

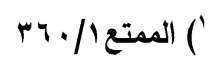

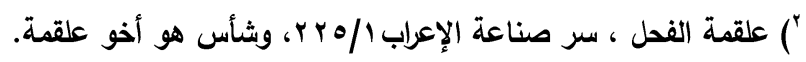

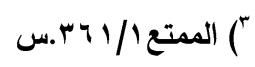


اطلحع ،منها ما فيه لغتان وهي الصَّاد نحو اصطلَح واصَّلح ،ومنها مـا فيه ثلاث لغات وهي الظاء نقول اظطلم اظلم واطّم.

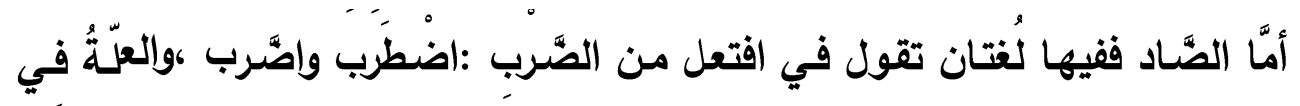
قلب التاء طاء أنَّ حروف الإطباق مستعلية مجهورة وإلَّاء متسفلة مهموسةٌ والجمع بينهما

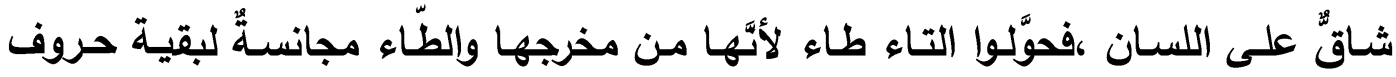

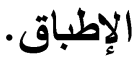

ومن قال "اصلّح " فأبدل من الطاء صادا وأدغم ليكون العمل من وجه واحد ولم

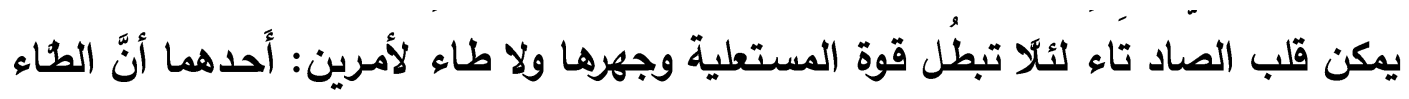
أخت الثَّاء في الْمخرج وقد تجنَبوا قلبها إليها فكذلك ما يقرب منها، والثَاني: أنَّه كان يلتبس

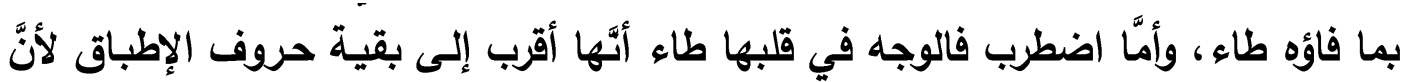

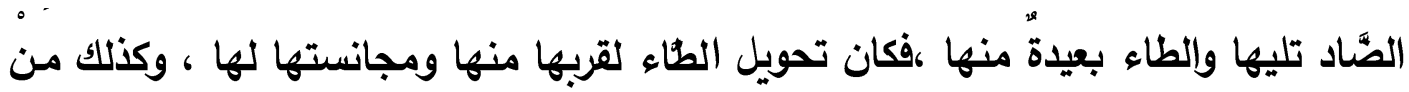

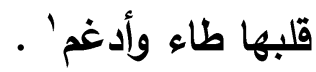

ص، ض ،ط، ظ+ ت ؟ ص ط، ض ط، طّ، ط

إذا التقى كل صوت من الأصوات السابقة مع التاء مجاورا لـه في صيغة افتعل أو إحدى مشتقاتها فإن هذه الأصوات الأربعة تؤثثر في صوت التاء تأثيرا تقدميَّا وتقلبه إلى مقابله المفذم، وهو الطاء لأن كل صوت من الأصوات السابقة يتسم بملمح قوة أكثر يجعله

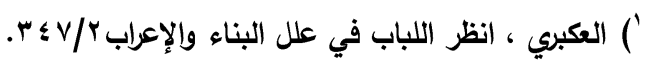




\section{د. حسن رمادي غانم نصر}

قادرا على التأثير في غيره من الأصوات المجاورة، فالصاد تتسم بالإطباق والصفير، والضـاد بـالتفخيم والاسـتطالة والتفثـي والجهـر والانفجـار، والطـاء بالإطبـاق والانفجـار، والظــاء بالإطباق والجهر، في حين أن صـوت التـاء يتسـم بـالترقيق والهمسس فهـو أضـفف مـن الأصوات السابقة لهذا أثرت فيه الأصوات فحولته إلى مقابله المفخم وهو صوت الطاء ليتم بذلك نوع من التماثل بين الصوتين المتجاورين في الصفة .

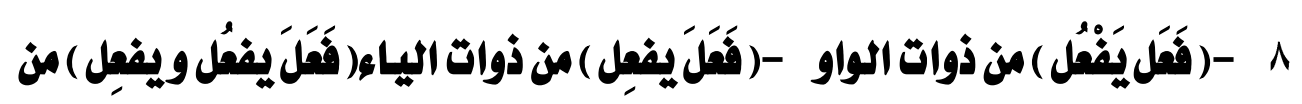

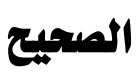
يقول أبو الحسن:" ...فالجواب من ذلك شيئان: أحدهما أنه لما حِّلِ" فَعَل" من ذوات الواو إلى "فَعَل" جاء مضارعه كمضارع "فَعل" فالتزموا فيه" يفْعل" بضم العين. وأما "فَعَلَ" من ذوات الياء فلما حول إلىى" فَعل" أشبهه " فَعُل" من ذوات الواو في أن بناء هما في الأصل "فَعل" مفتوح العين، وأن كل واحد منهما حولت حركة عينـه الأصلية إلىى حركة من جنس العين. فكما التزموا في مضارع "فَعل" من ذوات الواو أن تكون حركة العين مـن جنسـها، كذلك التزمـوا في مضـارع "فعل" مـن ذوات الياء أن تكون حركـة العين مـن جنسها".

ويمكن القول إنهم جعلوا يُعل بالصَّم مضارع فَعل من ذَوات الواوِ، وجعلوا يفعل بالكسر مضـارع فَعَل مـن ذوات الياء، إثـعارا بالأَصل، لأنَّ الصَّمَّةَة تشعر بـالواو والكسـرة 


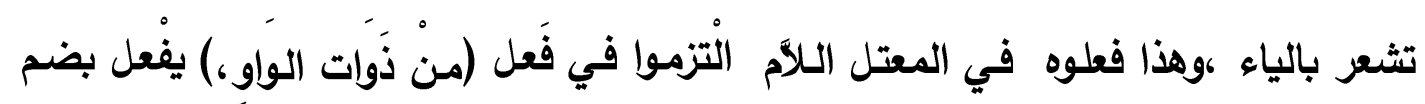

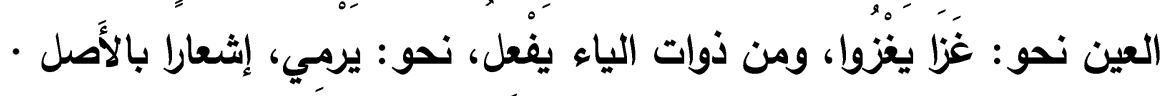

\section{الملة الثامسة: الإثباع}

الإتباع من العلل الصوتية التي علل بها ابن عصفور في الحالات التالية:

\section{1}

منهم من يكسر حرف المضارعة اتباعا للقاف ، أو على لغة من يقول في مضارع "|فتعل" : "يَتْعل" فيكسر حرف المضارعة، يقول أبو الحسن:" وإن كان أحد المثلين تاء" افتعل" نحو "|(قتتل" فإنـه يجوز فيهه الإظهاء والإدغام .أمسا الإظهار فلأنـه يثبه اجتماع المثلين من كلمتين في أنه لا يلزم تاء" افتعل" أن يكون ما بعدها مثلها كما لا يلزم ذلك في الكلمتين لأنك تقول " اكتسب" فلا يجتمع لك مثلان ، وإنما يجتمع المثّلان في "|فتعل" إذا بنيت من كلمـة عينها تاء نحو "|(قتتل" و"|فتتح" فكما لا تدغم إذا كان مـا قبل الأول من المثلين المنفصلين ساكنا صحيحا فكذلك لا تدغم في "|فتعل". أما الإدغام فلأن المثلين، على كل حال، في كلمة واحدة ، فتلغم كما تدغم في الكلمـة الواحدة .فإن أظهرت جاز لك في الأول من المثلين البيان والإخفاء لأنه وسيطة بين الإظهار والإدغام' . 


\section{د. حسن رمادي غانم نصر}

وإذا أدغمت جاز لك ثلاثة أوجه: أحدها أن تنقل الفتحة إلى فاء "|فتعل" ، فتحرك الفاء وتسقط ألف الوصل ثم تدغم ، فتقول" قتَّل" بفتح القاف. والثاني أن تحذف الفتحة من تاء "(فتعل" فتلتقي ساكنة مع فاء الكلمة، فتحرك الفاء بالكسر على أصل التقاء الساكنين ،

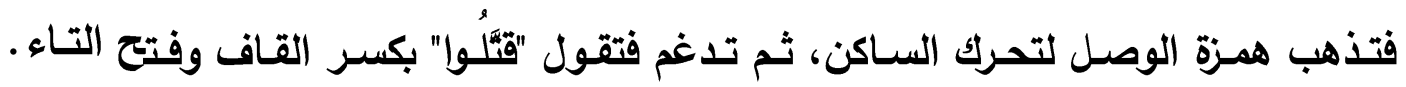

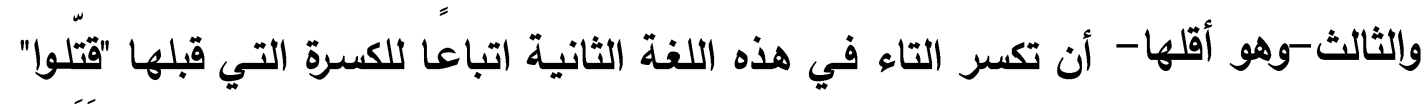
بكسر القاف والتاء" . فمن فتح التاء والقاف قال في المضارع "يقِّل" بفتح القاف وكسر التاء لأن الأصل "يقتِتِل" فنقل الفتحة في المضارع كما نقلها في الماضي.

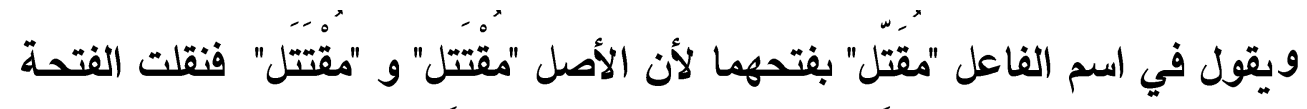
إلى الساكن قبلها كما نقلت في الفعل. ومن قال" قتَّل" بكسر القاف وفتح التاء. قال في

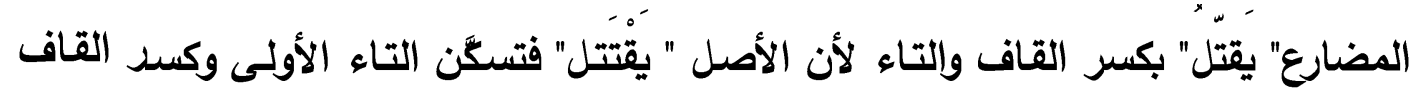

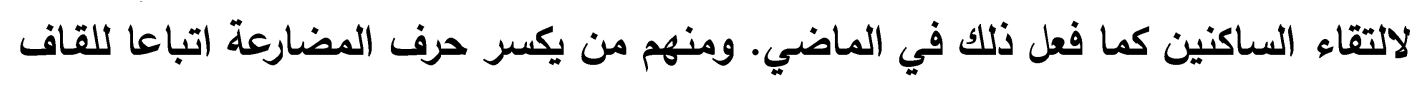

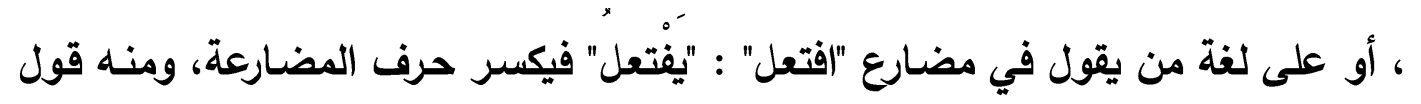

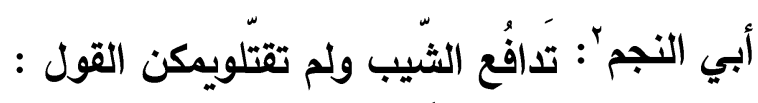

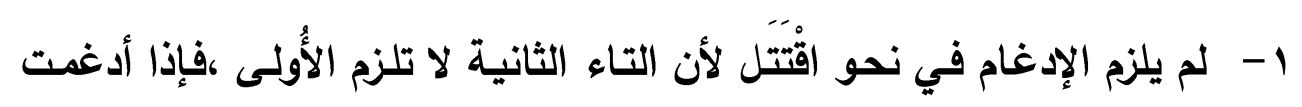
فإما أن تنقل حركة أولهما إلى فاء الكلمة كما هو الرسم في نحو يمد ويعض ويفر فتستغني

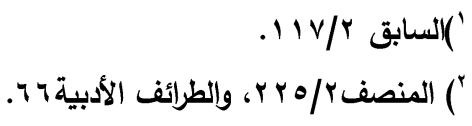

( حولية كلية الآداب- جامعة بني سويف عدد خاص - يناير (.T.T) 
عن همزة الوصل، وإمـا أن تحذف حركة أولهمـا فيلتقي سـاكنان :فاء الفعل، وتـاء افتعل، فتكسر الفاء، لأن الساكن إذا حرك فالكسر أولى، فتسقط همزة الوصل بتحرك ما بعدها. r- كسرة قَّل لتكون دليلًا على همزة الوصل المكسورة المحذوفة. r- تقول في مضـارع اقتتل المدغم يقَّل - بنقل الفتحـة إلحى القـاف - كمـا في الماضـي، ويقَتِل - بكسر القـاف - كمـا في الماضـي سـواء، وأجـاز بعضهم حذف حركـة أولهما من غير أن يحرك القاف بحركة، فيجمع بين ساكنين، وهو وجه ضعيف ينكره أكثر الناس، والأولى أن ما روي من مثله من العرب اختلاس حركة، لا إسكان تام، ويجوز في نحو يقَتل - بكسر القاف - أن تكسر الياء إتباعاً للقاف، فتقول :يقتّل، واللهاء. ع - يحمل أبو الحسن اسم الفاعل اسم المفعول على الفعل ، فيقول:

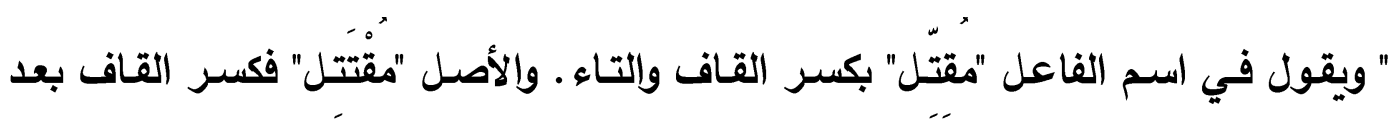
تسكين التاء الأولى لالتقاء الساكنين .

ومنهم مـن يستثقل الخروج من ضم إلى كسر فيضم القاف اتباعـا للميم فيقول "مقتّل" ولا يستثقل الخروج من ضمة القاف إلى كسرة التاء لأن بينهما حاجزا وهو التاء الساكنة. وفي اسم المفعول" مقَّل" بكسر القاف وفتح التاء لأن الأصل "مقتتِل" فتسكَّن التاء الأولى وحرك القاف بالكسر على أصل التقاء الساكنين، ومنهم من يستثقل الخروج من ضم 


\section{د. حسن رمادي غانم نصر}

إلى كسر بضم القاف وفتح التاء لأن الأصل مقتتَلَ فتسكَّن التاء الأولى وحرك القاف بالكسر على أصل التقاء الساكنين.

ومنهم من يستثقل الخروج من ضم إلى كسر فيضم القاف اتباعا للميم فيقول "مقُّل" بضم القاف وفتح التاء.

ه- من قال "قّتل" بكسر القاف والتاء فإن قياس المضارع منه واسم الفاعل واحد،

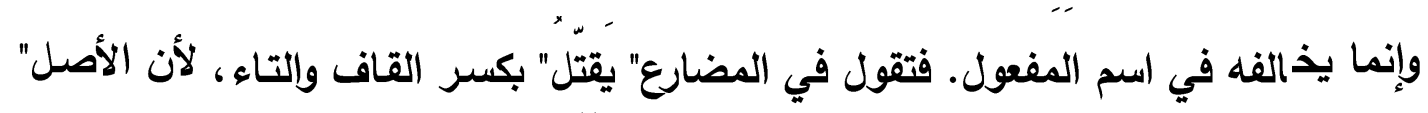

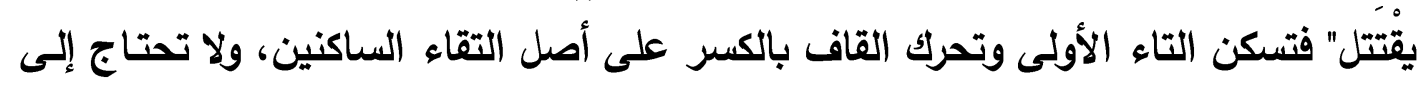

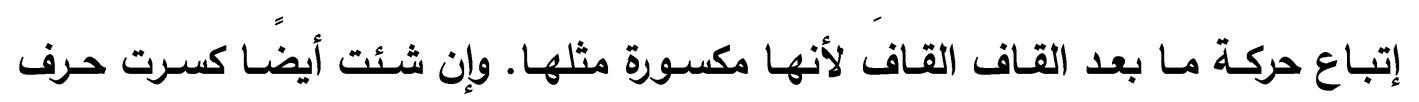

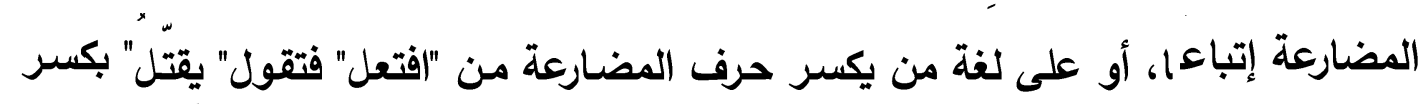
القاف والتاء التي بعدها وحرف المضارعة.

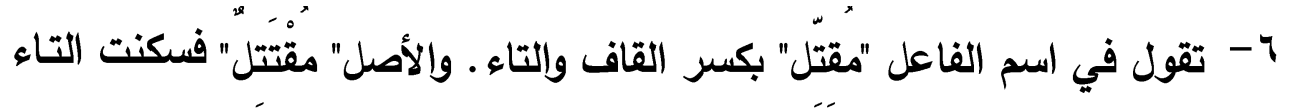
الأولى وكسرت القاف لالتقاء الساكنين ثم أدغمت، ولم تحتج إلى إتباع التاء لأن حركتها من جنس حركة القاف. وإن شئت ضمت القاف اتباعا لحركة الميم كراهية الخروج من

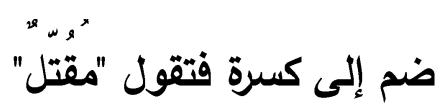
- V في اسم المفعول "مقتّل" كما تقول في اسم الفاعل لأن الأصل " مُقْتَّل" فسكنت

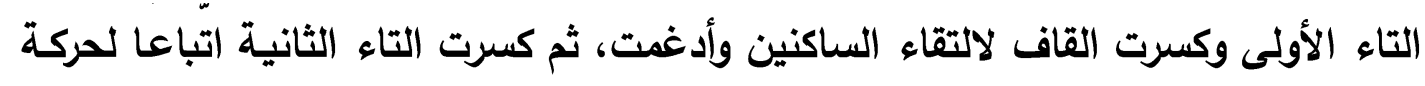

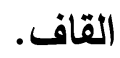


^- فلا يقع فرق بين اسم الفاعل ، على هذه اللغة ، واسم المفعول إلا بالقرائن فيكون نظير "مختار" في أنه يحتمل أن يكون اسم فاعل واسم مفعول حتى يتبين بقربنة تقترن بـه. ومن استثقل الخروج من ضم إلى كسر ، من غير حاجز، ضم القـاف فقال

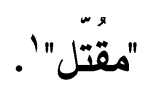
9- تقول في اسم الفاعل: مقتلِ - بكسر القاف وفتحها - ولا يجوز كسر الميم اتباعاً كما جاز كسر حرف المضارع، لأنَ حرف المضـارع متعود للكسر لغير الاتباع أيضًا

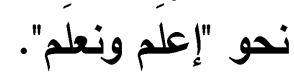

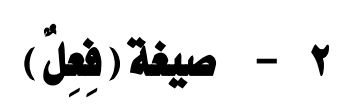

يقول أبو الحسن: " وحكى غيره:" أتان إبِد" للوحشية. فأما "إطل" فـلا حجة فيـه لأن

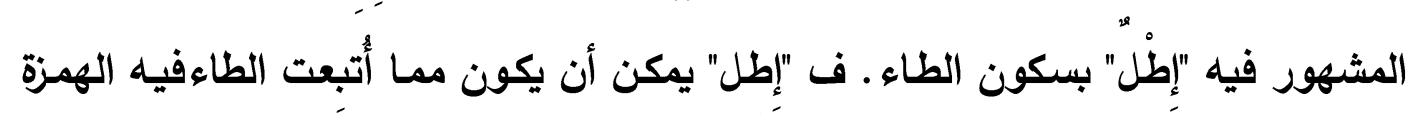
للضرورة لأنه لا يحفظ إلا في الثعر، نحو قولهلَ : له إطلا ظَبِيَ و ساقا نَعامةٍ

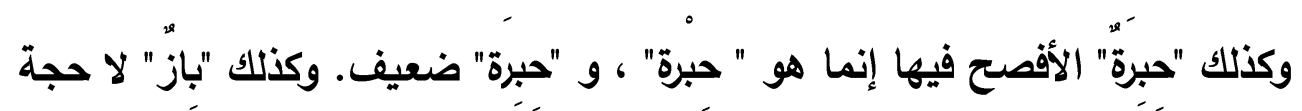

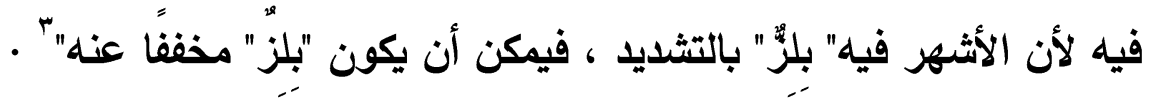




\section{وبمكن القول:}

1- لم يجيء على فعل إلا "إِِل"-خاصة فيما زعم سيبويه' - بكسرتين ، وإطل -

$$
\text { وهو الخَصرّ، وإِبد - لغة في الأبد بمعنى الدهر. }
$$

r- قالوا في سجعهم : أتان إبـد، في كل عام تلـ ولا يقـال هذا إلا في الأتـان

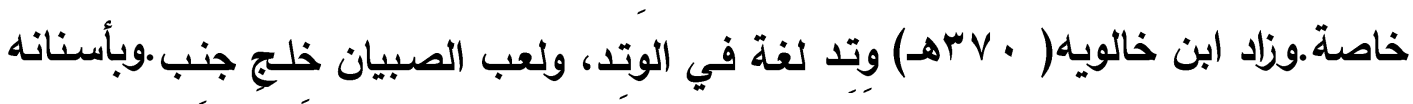
حبِر، أي صفرة، وامرأة بِلز أي ضخمة، والبِلص :طائر وهو البلصوص. وزاد ابن بري (

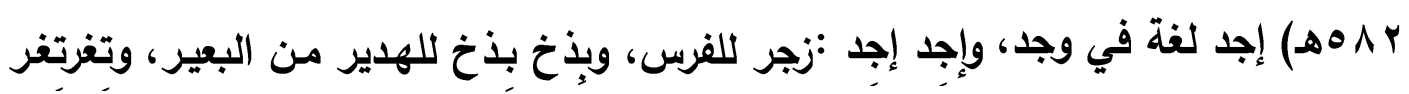
حكاية للضحك. وزاد أبو حيان في شرح التسهيل :مشط لغة في المشط، وإثر لغة في الأثر، ودبِ لغة في دبس، خطب نكح

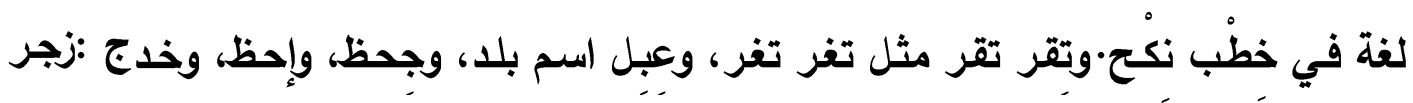

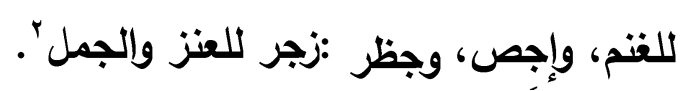

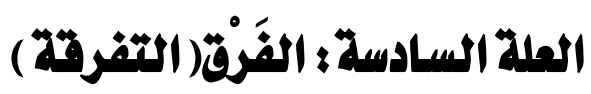

علة الفرق مـن العلل الصرفية الصـوتية التي علل بها أبو الحسن، وذلك في المسائل التالية:

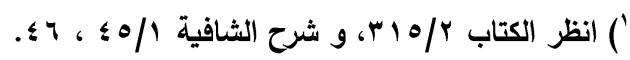

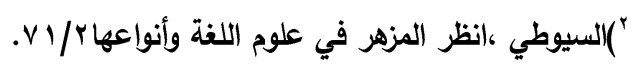

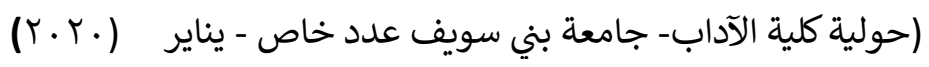




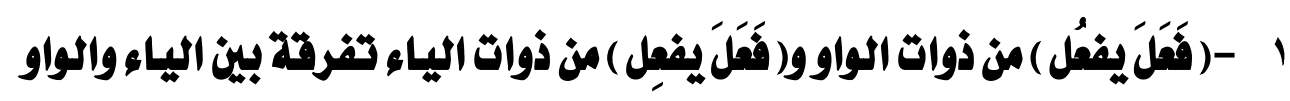

ذكر أبو الحسن (فَعَل يفعلُ) من ذوات الواو و (فَعَلَ يفعل) من ذوات الياء تفرقة بين

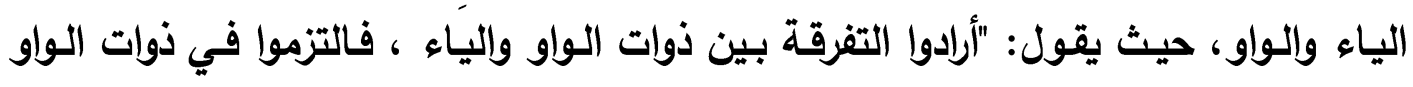

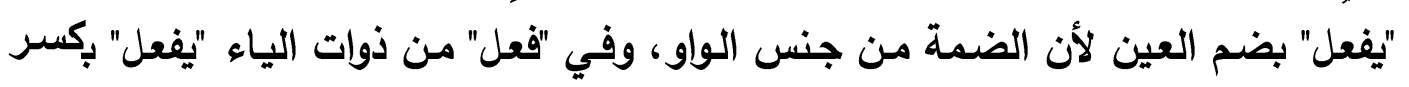
العين لأن الكسرة من جنس الياء.

وهذا الوجه أولى لأنهم قد فعلوا مثل ذلك في المعتل التلام: التزموا "فَعل" من ذوات

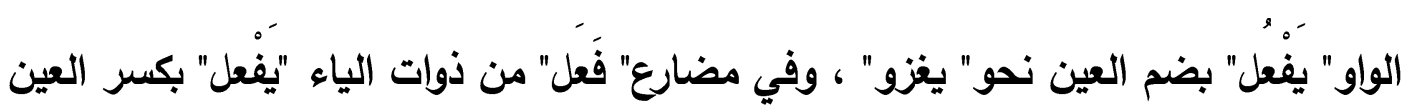

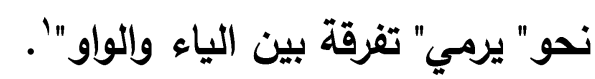

ويعلل أبو الحسن عدم جواز (فعل يفعل) من ذوات الواو و (فعل يفعل) من ذوات

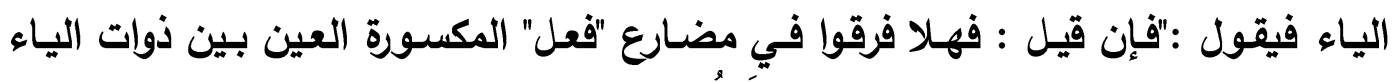

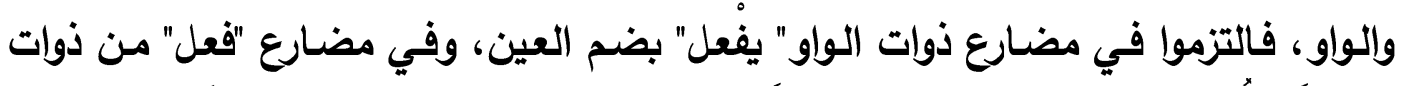

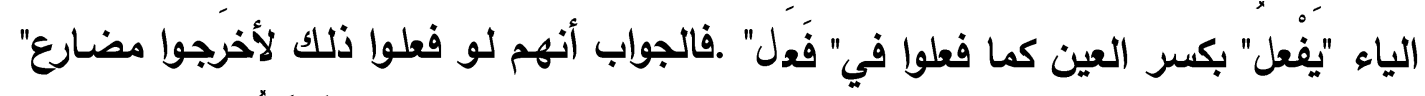

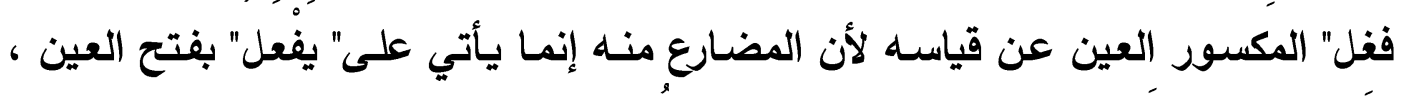

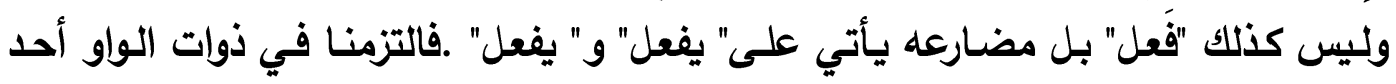

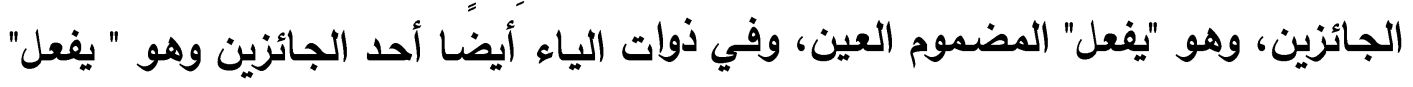

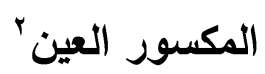

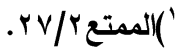

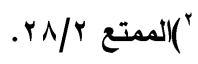

91

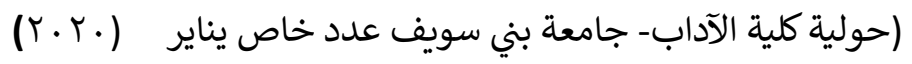




\title{
د. حسن رمادي غانم نصر
}

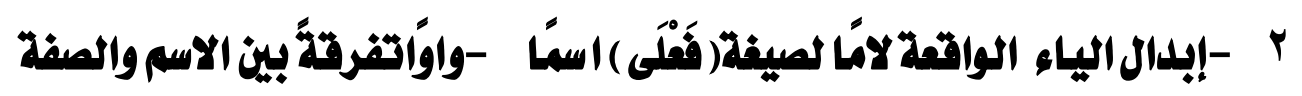

ذكر أبو الحسن قلب الأخف وهو الياء إلى الأثقل وهو الواو تبعا للمأثور من كـلام

العرب أن الياء تقلب واوا إذا وقعت لامـا ل(فَعلى):" إن كان المعتل اسما فـلا يخلو من أن إن الن يكون على ثلاثة أحرف أو على أزيد. وكيفما كان فإنه لا يخلو من أن يكون ما قبل حرف

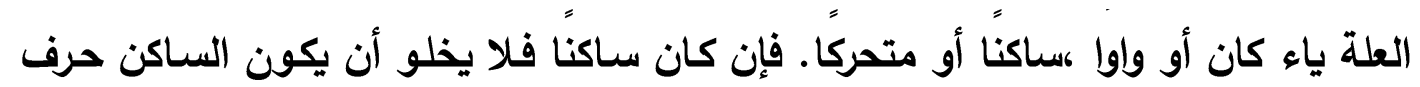
علة أو حرفًا صحيحا. فإن كان الساكن حرفًا صحيحا جرت الياء والواو مجرى حرف الصحة

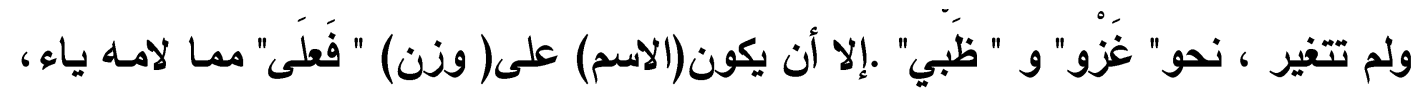
وذلك قولهم" شـروى" و "تقوى" و "فتوى" ـ فبإن العرب تبـل مـن الياء واوا في الاسـم ،

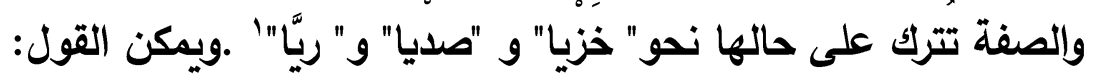
ا- تبدل الواو من الياء في" فَعَلَ "إذَا كانت اسما والياء موضع اللام ،يقولون: لكَّ

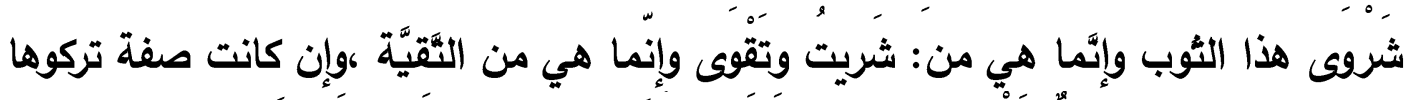

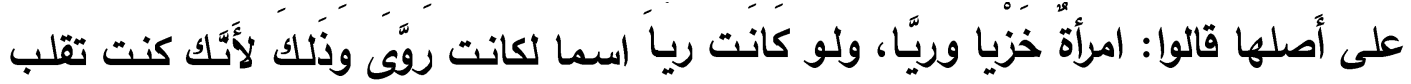

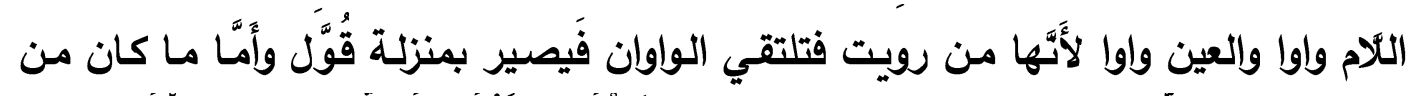

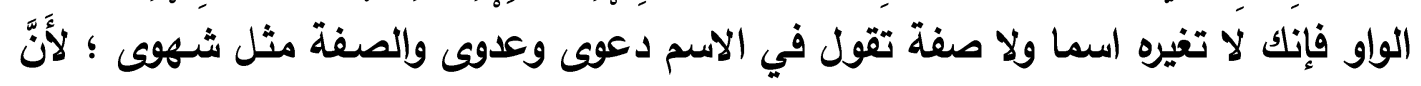

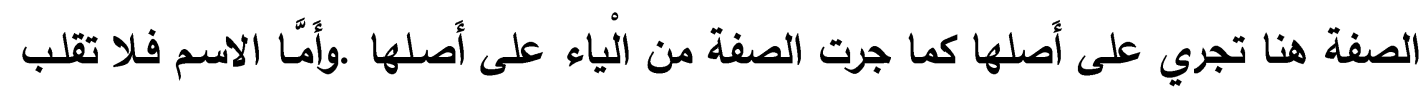

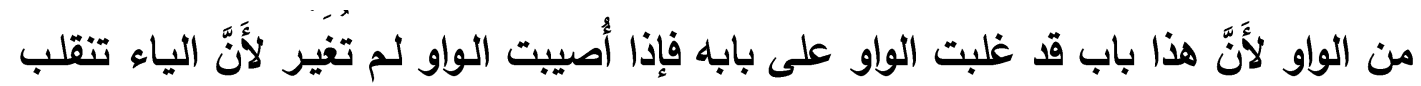

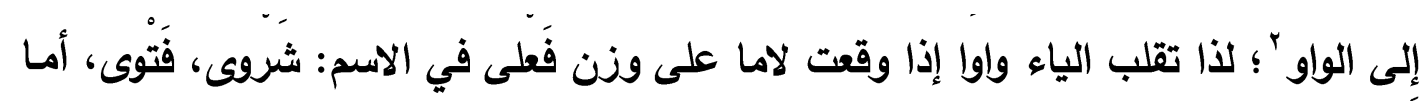

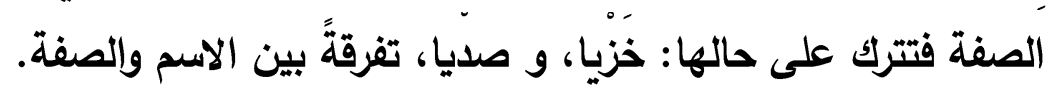

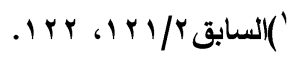

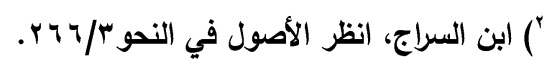

(حولية كلية الآداب- جامعة بني سويف عدد خاص - يناير (.r. ) 
ץ- لاحظ ابن عصفور أن قلب الأخف وهو الياء إلى الأثقل وهو الواو لم يقَل لولا

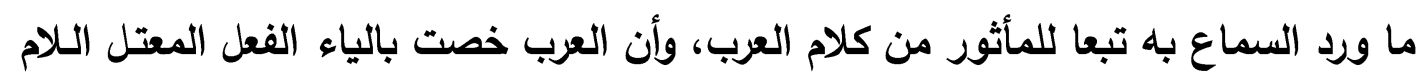
، ولم تخص بها المعتل العين أو الفاء لأن الياء أقبل للتغيير لتأخرها وضعفها. r- وقعت الياء بوصفها نصف حركة ضعيفة في باية مقطع متوسط (ص ح ح ح ) فعد الناطق إلى تقوية المقطع عن طريق قلب نصف الحركة الياء إلى نصف حركة أقوى منها وهي الواو، ومن المفترض أن يبدأ المقطع بصامت قوي، فعمد الناطق إلى تقويـة

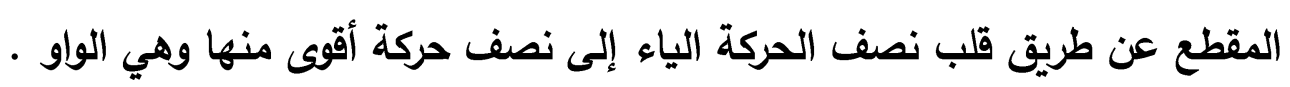

\section{الملة السبابوة: الثمة}

كثير من مسائل الإعلال والإبدال والإدغام تكره الاستثقال ، وتوالي الأمثال، وتميل إلى الخفة ، ،مـن الركائز اللفويـة في تعليل ابن عصفور إيثار الخفـة وذلك على أوجـه

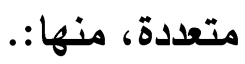

\section{أوئًا تخفيف الهمزة بالإثباع: -}

\section{1 - إبلال الواومز الهمزة}

- إذا لم تنضم إليها همزة أخرى

يقول أبو الحسن:" وأما الواو فأبدلت من ثلاثة أحرف، وهي الهمزة والألف والياء، إلا أن الذي يذكر هنا إبدالها من الهمزة لأن إبدالها من الياء والألف يذكر في باب القلب. 


\section{د. حسن رمادي غانم نصر}

ويمكن القول إن وقوع همزة واحدة في الكلمة وقلبها هومن باب تخفيف الهمز ولم

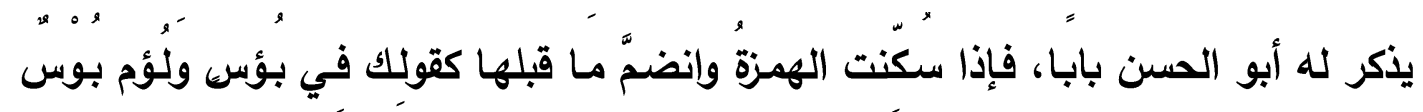
ولُوم ، وحجة من لم يهمز أن يقول: إنَ هذه الهمزة قد لزمها البدل في مثالين من الفعل الماضي والمضارع، فالماضي نحو :آمن وأومن، والمضارع نحو أومن ' ولم يجز تحقيقها في هذه المواضع. وهذا القلب الذي لزمها في المثالين إعلال لها، والإعلال إذا لزم مثالاً أتبع سائر الأمثلة العارية من الإعلال :كإعلالهم يقوم لقام، وإعلالهم يكرم من أجل أكرم، وأعد ليعد، فوجب على هذا أن يختار ترك الهمز في يؤمنون لا على التخفيف القياسي في نحو جونة ب في جؤنة وبوس في بؤس ، فتبدل من الهمزة باطراد إذا كانت مفتوحة وقبلها

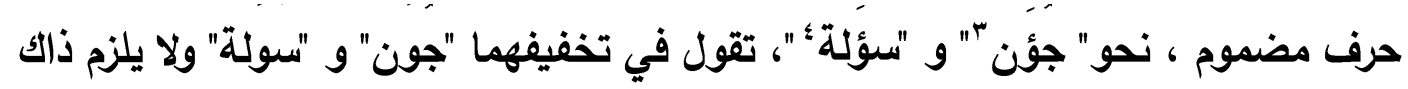
- إذا انضم إليها همزة أخرى يقول أبو الحسن: " فإذا انضم إليها همزة أخرى فلا يخلو أن تكون الثانية ساكنة أو متحركة. فإن كانت سـاكنة فإنـه يلزم إبدالها واوا إذا كانت الهمزة الأولى مضمومة، فتقول

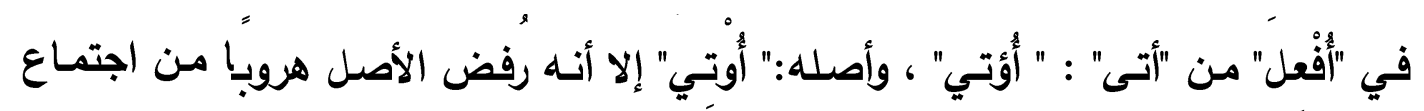
'المفالماضي نحو آمن والمضارع نحو أومن. ") الجؤنة: سفط مغشى بجلد، ظرف لطيب العطار.

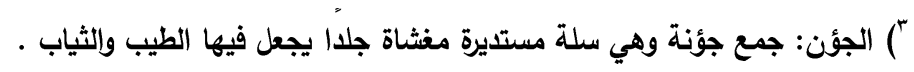

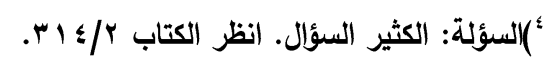

(حولية كلية الآداب- جامعة بني سويف عدد خاص - يناير (·. ) 
الهمزتين فلزم البدل. فإذا كانت الثانية متحركة فإنها تبدل واوا إذا كانت متحركة بالضم أو بالفتح...

وسواء كان ما قبل هذه الهمزة المفتوحة مفتوحا أو مضموما في التزام إبدالها واوا.

فمثال انضمام ما قبلها" أُواتي" في مضارع "آتَى" : (قاعل) من الإتيان، أصله "أُؤاتي" ، ثم التزموا الببل هروبا من اجتماع الهمزتين، ثم حملوا "يواتي" و" نُواتي" و" مواتٍ" على" أواتي" في التزام البدل.

تبدل الهمزة الثانية" واوا بعد ضمة نحو: أوتمن"، بالبناء للمفعول، أصله :أؤتمن " بهمزتين، مضمومة فسـاكنة، قلبت الهمزة الثانية واوا لسكونها وإنضمام مـا قبلها، "وأجاز الكسـائي أن يبتـأ" أؤتمن "بهمزتين "مضمومة فسـاكنة، "نقله عنه ابن الأنباري في كتاب الوقف والابتداء، ورده "بأن العرب تجمع بين همزتين الثانيـة منهمـا سـاكنة، ذكر هذا الرد

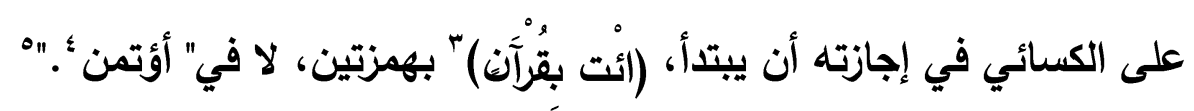
ويمكن القول إذا اجتمع همزتان في كلمة بينهما فاصل جاز تحقيقهما، فالفاصل قـ نفى وجوب التخفيف لزوال الثقل بالفصل بين الهمزتين، فعبر المصنف عن ذلك بنفي تأثير

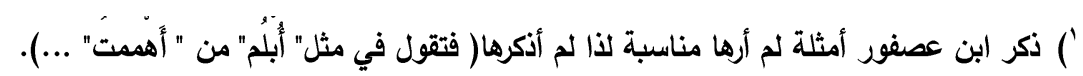

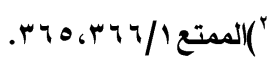
أب آن يونس: 10 ") أن تلتقي همزتان في كلمة وتسكن الثانية بعد ضم. فإنها يجب إبدالها واواً .وذلك نحو :أومن وأوثر .والأصل :أؤمن وأؤثثر. إلا أنه رفض الأصل هروبا من اجتماع هزتين.

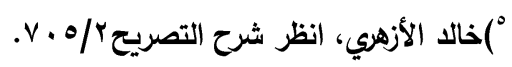




\section{د. حسن رمادي غانم نصر}

اجتماع الهمزتين بفصل، وإذا لم يكن لاجتماعهما مع فاصل تأثيره انتفى وجوب التخفيف ، فيقال: "أوتي" ، أصله أؤتي: اجتمعت همزتان الأولى متحركة والثانية سـاكنة فقلبت حركة من جنس حركة سابقتها، حيث استثقل اجتماع همزتين أدى إلى إحداث مخالفة بين حرفين متماثلين ثقيلين بهدف تسهيل النطق تخلصا من اجتمـاع الثقيلين ، وهما الهمزتان، هذا التخالف تجسد فيقلب الهمزة الثانية إلى حركة قصيرة من جنس الحركة القصيرة السـابقة عليها.

وإذا انتفى وجـوب التخفيف جـاز التحقيق، ثم لمـا كـان نحو :ذوائب اجتمـع فيـه

هزتان بفاصل، ومع ذلك كان لاجتماعهما تأثير؛ لأن الهمزة الأولى خففت بإبدالها واوا.

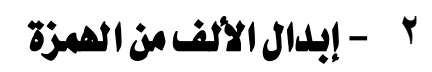

يقول أبو الحسن:" وأمـا الألفف فأبـلت من أربعة أحرف، وهي: الهمزة، والياء، واللواو، والنون الخفيفة. إلا أن الذي يذكر هنا إبدالها من الهمزة والنون لأن إبدالها من الياء والواو من باب القلب.

فأبدلت من الهمزة باطراد إذا كانت ساكنة وقبلها فتحة نحو "رأس" و"كأس" ، تقول فيهمـا إذا خففتهمـا "كـاس: و" راس" ، إلا أنـه إذا كـان الحرف المفتـوح الذي تليـه الهمـزة

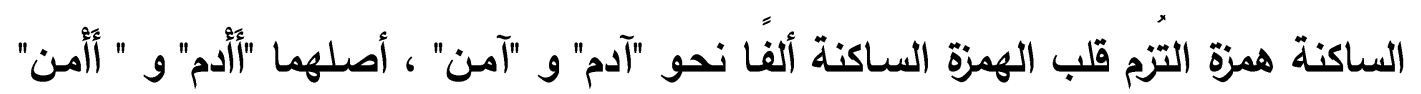
إلا أنه لا ينطق بالأصل استثقالًا للهمزتين في كلمة واحدة' . 
ويمكن القول إن سكنت الهمـزة بعد غير همزة، جـاز أن تخفف بإبدالها مدة من جنس حركة ما قبلها كانت فاء نحو :يامن، ويومن، وييبى في :يأمن، ويؤمن، ويئبى من كلمـة كهذا، أو متصلة بأخرى كالذي اؤتمن، وإن ايتمن، وأحمد وتمن أي :الذي اؤتمن، وأحمد ئتمن، وإن ئتمن، أو عينا نحو :كاس، وبير، وبوس، في كأس، وبئر وبؤس، أو لامـا نحو :بدات، ولم أقرا، وبـديت، ولم أقرى، ووضوت، ولم أوضـا في :بدأت، وأقرأ، وبـئت، وأقرئ، ووضؤت، وأوضأ' لاجتماع الهمزتين وانفتاح الأولى وسكون الثانية' .

\section{r - بإبلدال الألف من المهزة على غير قياس}

يقول أبو الحسن:" وأبدلت على غير قياس من الهمزة المفتوحة المفتوح مـا قبلها وإنما يحفظ حفظًا، نحو قولهَّا إذا ملا بطنَه ألبانْها حلبا يريد "ملأ" فأبدل من الهمزة ألفاً. ومن أبيات الكتاب؛؛ فَارعي فزارة لا هناك المرتعَع راحتْ بمسلمةَ البغال عثيَّةً يريد "لا هَنَكَ" فأبجل الهمزة ألفًا.

$$
\begin{aligned}
& \text { ') 'أبوحيان، انظر ارتثاف الضرب//YVY }
\end{aligned}
$$

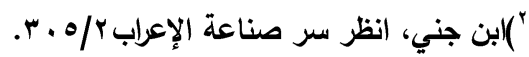

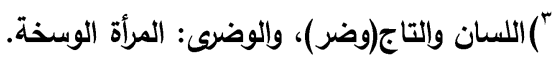

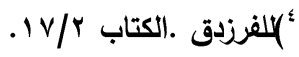


ومن أبيات الكتاب أيضًا' :

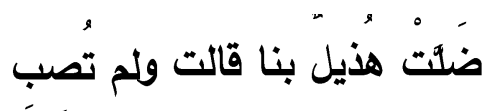

سالت هذيل رسول الله فاحثةً

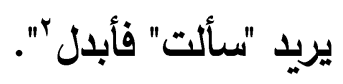

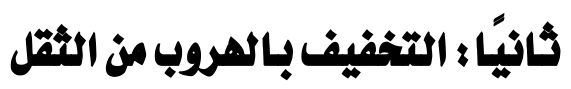

عبر سييويه عن كراهة توالي الحروف المتماثلة بكراهية التضعيف وعقد لـه بابا سماه :"هذا باب التضعيف" ،وذكر أن اختلاف الحروف أخف عليهم من أن يكون من موضـع واحد، فالصـوتان المتمـاثلان يحتاجـان إلـى مجهود عضلـي للنطق بهمـا في كلمـة واحدة. وقد ربط علماء اللغة المحدثون بين ظاهرة كراهة توالي الأمثال في العربية و ظاهرة "المخالفة الصوتية" التي تُعدُّ أثرا لقانون الاقتصاد في الجها . أما عن المسائل التي علل بها ابن عصفور التخفيف بالهروب من الثقل فهي على

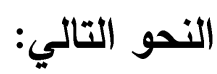

\section{1}

يذهب أبو الحسن إلى القياس في همز الواو من مثل "وعاء" ، حيث يقول: "فإن كانت وحدها فلا يخلو من أن تكون مضمومة، أو مكسورة، أو مفتوحة.

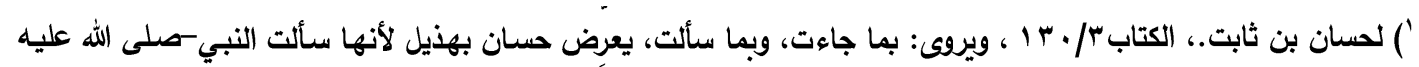

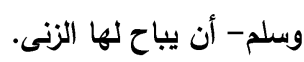

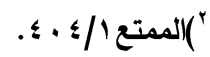
. I 
فَإن كانت مكسورة أو مضمومة جاز أن تبدل منها همزة، فتقول في "وعدَ": "أُعدَ"،

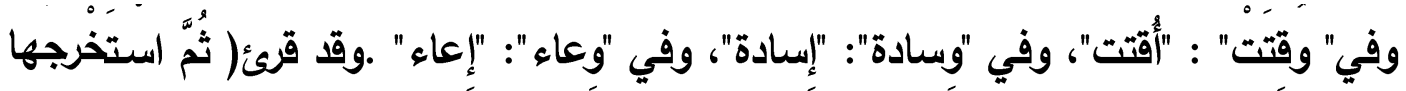

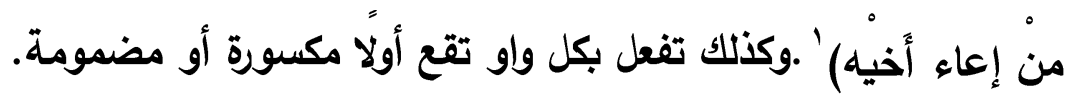
ويمكن القول إن سبب ذلك ثقل الضمة والكسرة في الواو وذلك أن الضمة بمنزلة

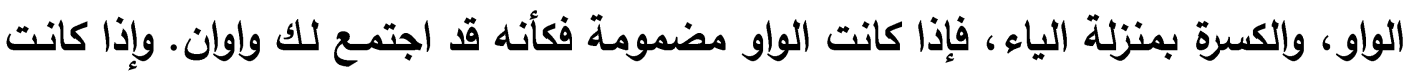
مكسورة فكأنه قد اجتمع لك ياء و واو. فكما أن اجتماع الواوين ، والياء والكواو مستثقل ، فكذلك اجتماع الواو والضمة

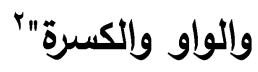
وزعم المازني أنه لا يجوز هز الواو المكسورة بقياس، بل يَّبِع في ذلك السماع، وهذا الأي ذهب إليه فاسد قياسا وسماعا. أما القياس : فلأن الواو المكسورة بمنزلة الياء والثواو، فكما يكرهون اجتماع الياء واللواو حتى يقلبون الواو إلى الياء -تقدمت أو تأخرت- فيقولون "طويت طيًّا" والأصل: طَويا، ويقولون :"سيد" والأصل: "سيود" فكذلك ينبفي أن يكون النطق بالواو المكسورة مستثقلاً. وأما السماع فلانهم قد قالوا "إسـادة" و "إيشـاح" و "إعاء" و "إفادة" وكثر ذلك كثرة توجب القياس في كل واو مكسورة وقعت أولاً"' .

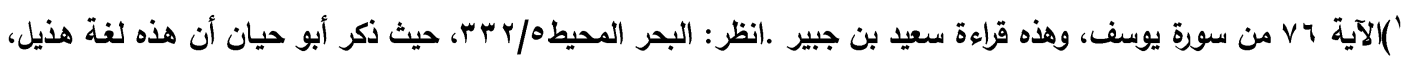

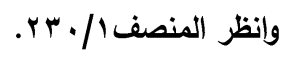

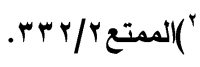




\section{د. حسن رمادي غانم نصر}

ويمكن القول أيضًا إنه لما ثقلت الواو بحركتها بالكسر فكأنما اجتمع واو وياء وذلك

مستثقل فأبدلت همزة تقوية للمقطع في بدايته لأنها صامت نبري قوي.

\section{r - جوازهزالواو -غيزأول - مشعومة}

يجيز أبو الحسن إبدال الهمزة من الواو المضمومة حشوا بشرط أن تكون الضمة

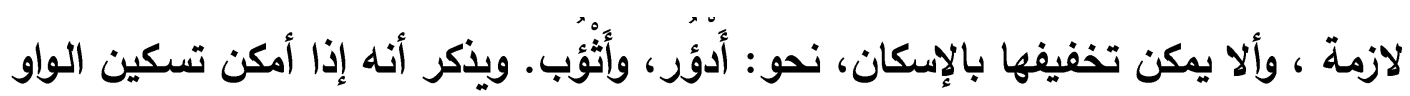
ـأن كان قبلها متحركا- لم تبدل همزة، نحو قولهم "سور" في جمع سوار، حيث يقول: "فأن وقعت غير أول فـلا يخلو مـن أن تكون مكسورة ، أو مفتوحسة، أو مضمومة. فبإن كانت مضمومة جاز إبدالها همزة بثرط أن تكون الضمة لازمـة، وألا يمكن تخفيفها بالإسكان.

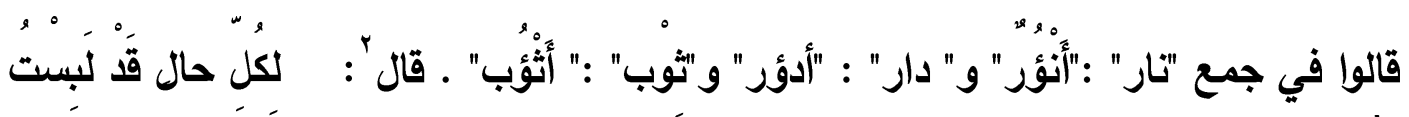

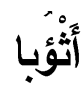

ويمكن القول: قلبت هزة لما ذكرنا من استثقال الضمة في الواو، مـع أنه لا يمكن تخفيفها بالإسكان لئلا يؤدي ذلك إلى التقاء الساكنين. ولو أمكن ذلك لم تُبدل همزة ، نحو قولهم: "سور" في جمع "سوار" ".

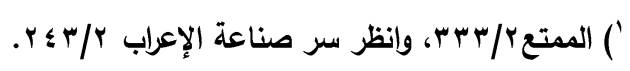

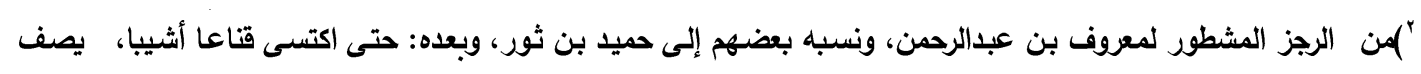

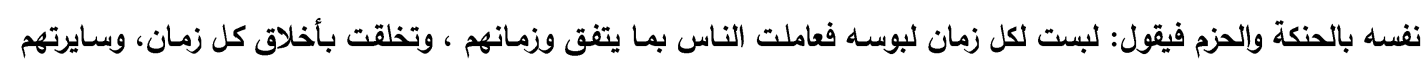

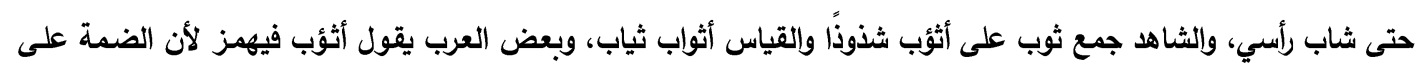

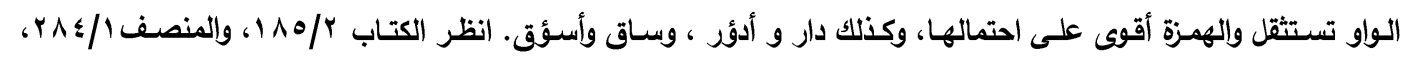

$$
\text { واللسان(ثوب). }
$$

(حولية كلية الآداب- جامعة بني سويف عدد خاص - يناير (·. ) 
فإن كانت الضمة غير لازمة لم تبدل الواو همزة، لا تقول هذا "غزء " تربد هذا" غزو" ، ولا تقول" لؤ استطعنا" تريــ " لو استطعنا" لأن الضمة في "غزو" إعراب، وفي واو" لو" لالتقاء الساكنين. وحركة الإعراب وحركة التقاء الساكنين عارضتان فلا يعتد بهما' . ويمكن القول أيضًا إن الواو أثقل حروف العلة تحركت بالضم وهو أثقل الحركات ممـا ضـاعف الاستثقال فأدى ذلك إلى قلبها همزة تخفيفًا لهذا الثقل، من باب المخالفـة الصوتية لإحداث نوع من التفير الصوتي في بعض البنى تجنبا لبذل مجهود عضلي ناجم عن ثقل الواو والضمة.

\section{r - بلب الواو -غير أول - المكسورة همزة}

ذكر أبو الحسن أن الواو تقلب همزة إذا وقعت ثاني حرفي لين بينهما ألف "مفاعل" سواء كان اللينان ياءين أو واوين، حيث يقول: "فإن كانت مكسورة ، أو واقعة موقع حرف مكسور فلا يخلو أن تقع بعد ألف الجمع الذي لا نظير له في الآحاد ـ فإن وقعت بعدها فلا يخلو أن يكون قبل الألف ياء أو واو ، أو لا يكون.

فإن كان قبلها واو أو ياء لزم قلب الواو همزة إن كانت تلي الطرف، فتقول في جمع "أوَّل" : " أوائلس"، وفي جمـع" سيد" : " سيائد"، والأصسل :" أواول ، و سـياود، فقلبت الـواو همزة لاستثقال الواوين والألف، أو الياء والواو والألف ، وبنـاء الجمع الذي لا نظير لـه في الآحاد. 


\section{د. حسن رمادي غانم نصر}

هذا مذهب جمهور النحويين إلا أبا الحسن الأخفش ، فإن كان لا يهمز من ذلك ألا ما كانت الألف منه بين واوين ، ويجعل ذلك نظيرا للواوين إذا اجتمعا في أول الكلمة. فكما أنكك تهمز الأولى منهما للعلة التي تقدم ذكرها، فكذلك تهمز الواو الآخرة في "أوائل" وأمثاله. ولايرى مثل ذلك إذا اجتمعت ياءان أو واو وياء، ويقول: لأنه إذا التقى الياءان أو الياء والثواو أولاً نحو "يين" اسم موضع و"ويل" و"يوم" لم يلزم الهمز. فكنلك لا يهمز عنده مثل

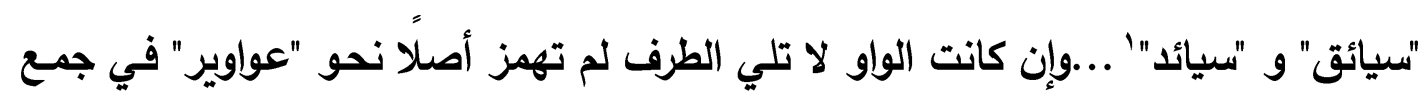
"عوار" و" طواويس" في جمـع "طاووس" لأنها قد قويت ببعدها عن محل التغيير وهو الطرف ‘

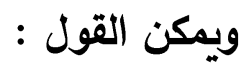

1- إن الهمزة تبلل من الواو والياء إذا وقعت إحداهما ثاني حرفين لينين، بينهما ألف" مفاعل "سواء كان اللينان ياءين ك"تيائف؛ جمع؛ نيف"، وهو الزيادة على العقد، وهو

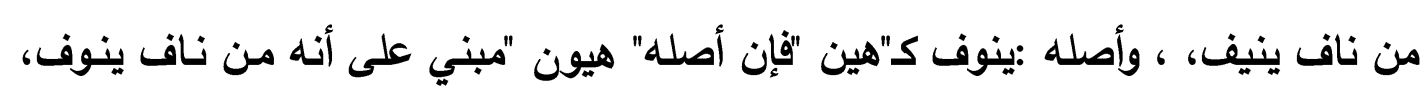
أو واوين ك: أوائل جمع أول، أو مختلفين بأن تكون إحداهما ياء والأخرى واوا كـ: سيائد جمع سيد ، أصله :"سيود" اجتمع فيه الواو والياء، وسبقت إحداهما بالسكون، قلبت الواو

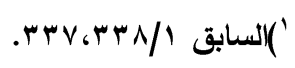

$$
\begin{aligned}
& \text { ") }
\end{aligned}
$$

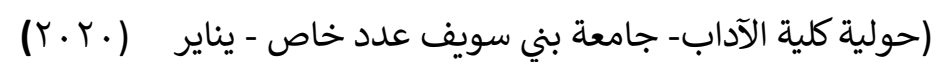


ياء، وأدغمت الياء في الياء، وسبقت فأبدل مـا بعد ألف الجمع همزة في الأمثلة الأربعة استثقالا لتوالي ثلاث لينات متصلة بالطرف، وأما قوله'"

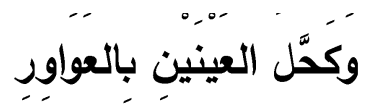

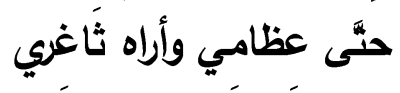

بغير إبدال، "فأصله: بالعواوير "بياء قبل الراء، لأنـه جمـع: عوار "بضم المعين

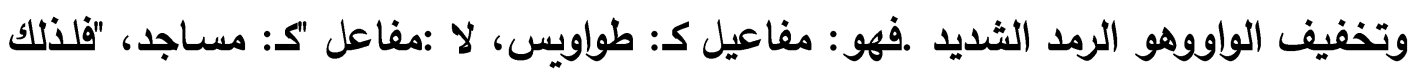
صحح "فيه الواو لبعده من الطرف، ثم حذفت الياء ، وبقي التصحيح بحاليه، لأن حذف الئ الياء

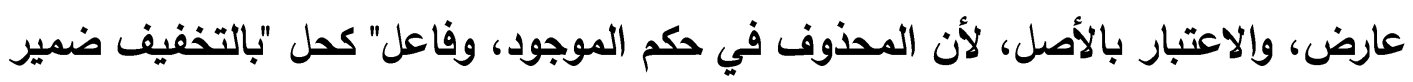
يرجع إلى الدهر في أبيات قبله.

ץ- ذهب الأخفش إلى أن الهمزة في الواوين فقط، ولا همزة في الياءين، ولا في

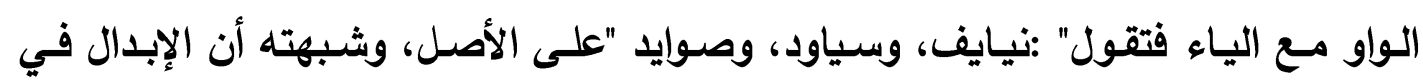

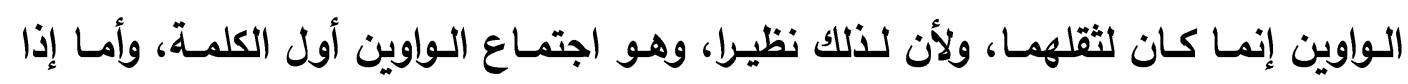

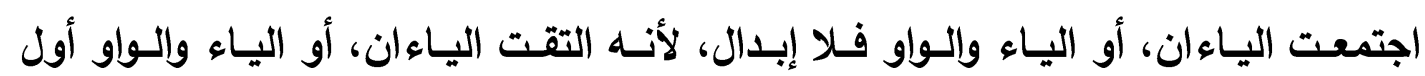

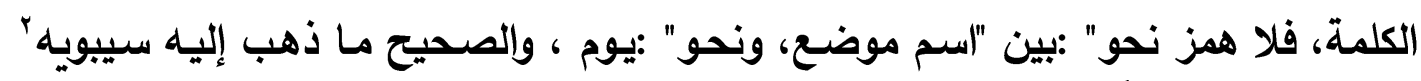

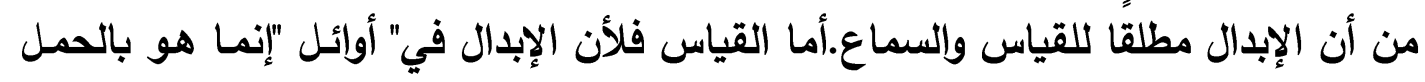

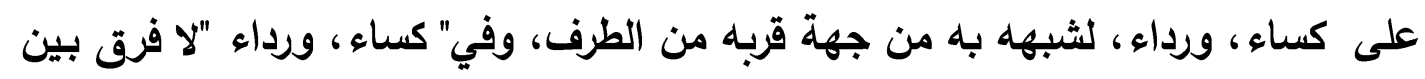

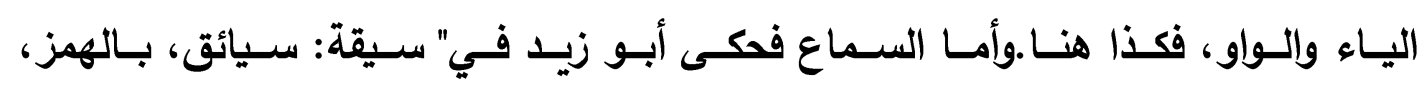

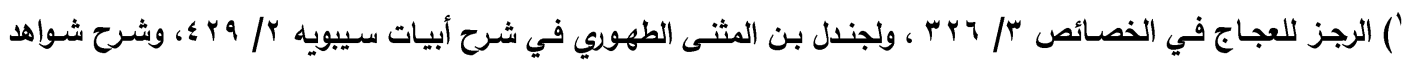

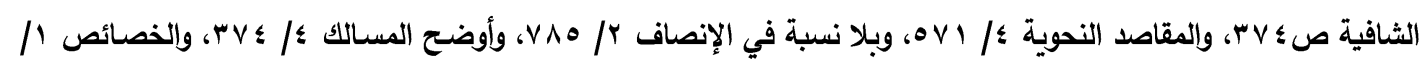

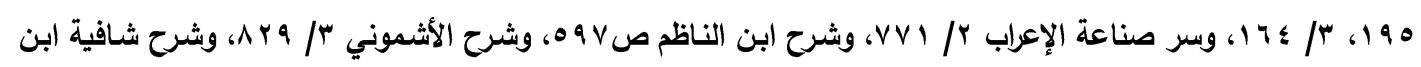

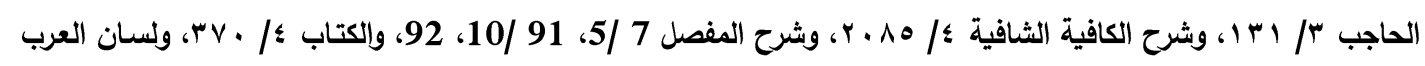

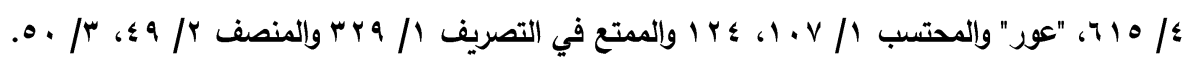

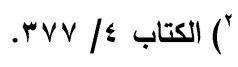

103

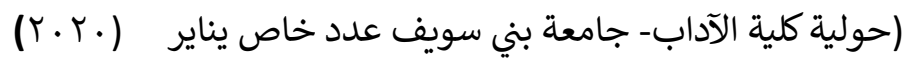




\section{د. حسن رمادي غانم نصر}

وهي" فعيلة "من" ساق"، وحكى الجوهري(ب ج rهـ) في تاج اللغة :جيد وجيائد بالهمز .وفهم

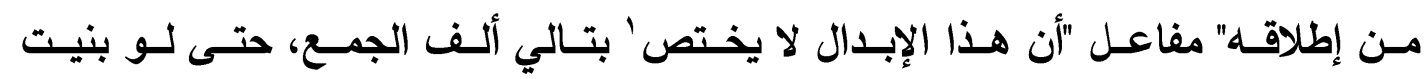

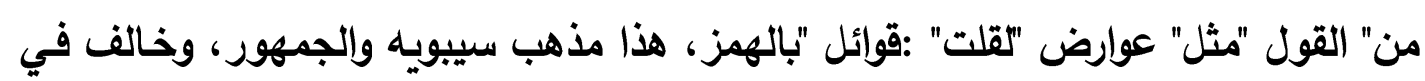
ذلك الأخفش والزجاجن، قذهبا إلى منع الإبدال في المفرد لخفته بخلاف الجمع.

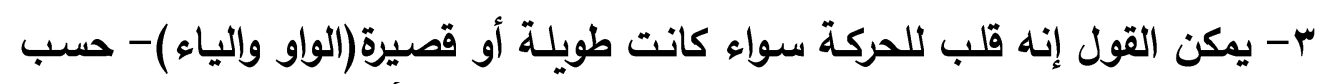
المثال - إلى صامت انفجاري نبر قوي وهو الهمزة تلافيا للتعاقب الصوتي لتلك الحركات .

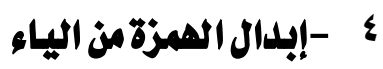

يقول أبو الحسن :"لياء تبدل همزة باطرّاد إذا وقعت بعد الألف التي في الجمع الذي لا نظير له في الآحاد، في مذهب سيبويه، بشرط أن تكون قد زيدت في المفرد للمد نحو لوك "صحيفة وصحائف" و "كتيبة وكتائب".

فإن لم تكن الياء زيلـت في المفرد للمد لم تهمز، إلا بشرط أن تكون تلي الطرف

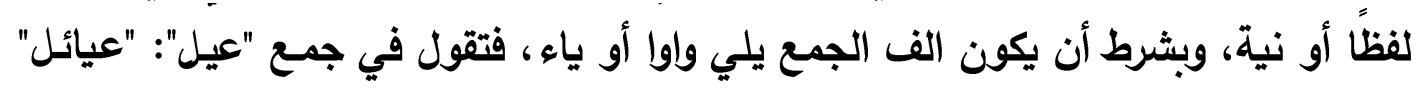

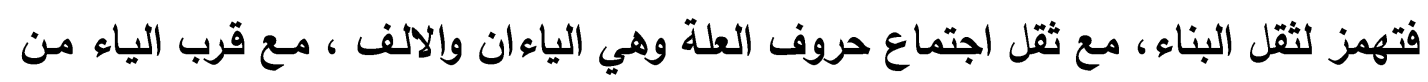
محل التغيير وهو الطرف.

وكذلك لو اضطررت فقلت في جمعه "عيائيل" فزدت ياء لهمزت لأن الياء في النية

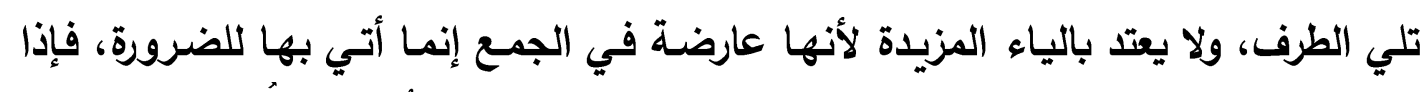

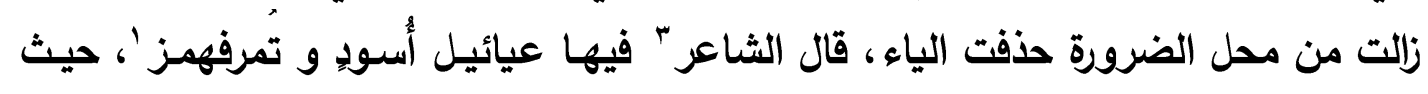

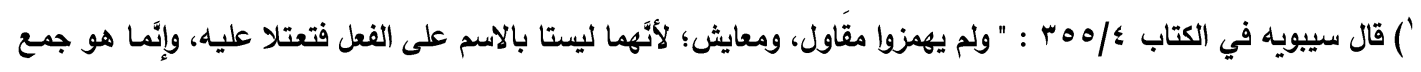

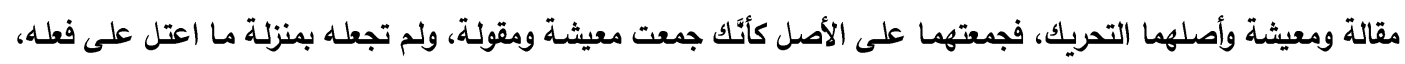

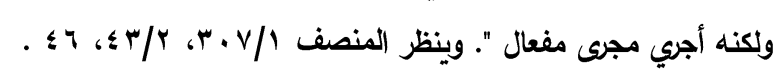

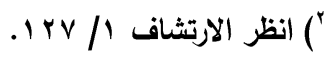

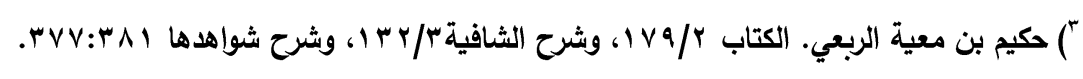

(حولية كلية الآداب- جامعة بني سويف عدد خاص - يناير (.r. ) 
أبدلت الهمزة من ياء فعاييل، قال ابن هشام :لأن أصله: فعايل؛ لأن عيائيل جمع عيل -

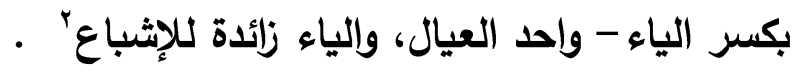

والياء الثانية في عيائيل مثل ياء الصياريف للإثباع، لأنه جمع عيلِ، وإنما يجمِع

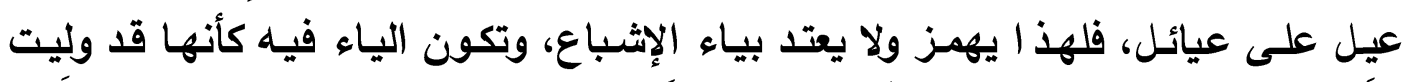

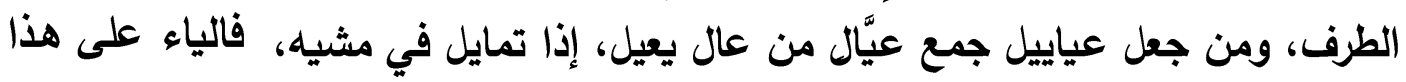

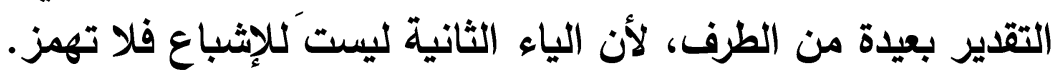

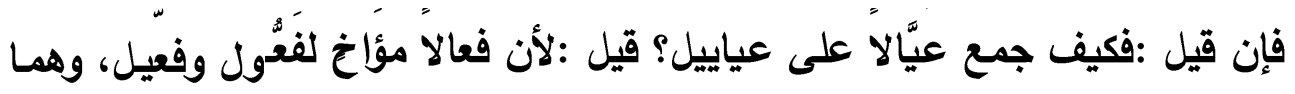

يجمعان على فعاعيل، والمؤاخاة من أجل وقوع حرف على اللين في الثلاثة بين العين وَآللام " . وبهذا فسره ابن السيرافي(1 \بهـ) في شرح أبيات سيبويه، قال " :العيال المتبختر

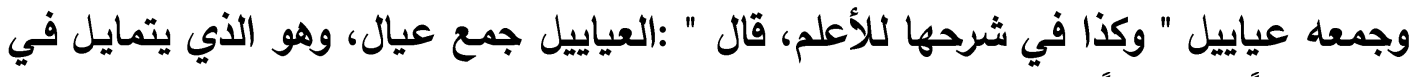

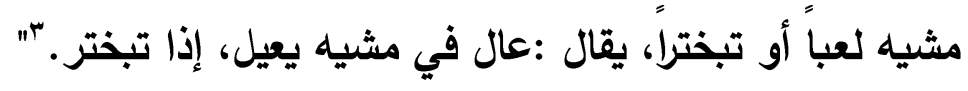

ويمكن القول إن الهمز هنا أدى إلى تحقيق هدفين: الأول: التخلص من تعاقب

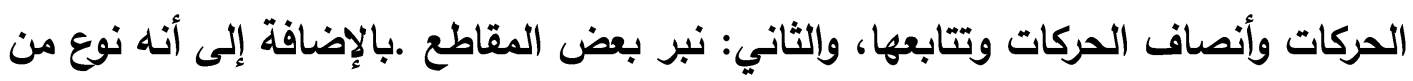

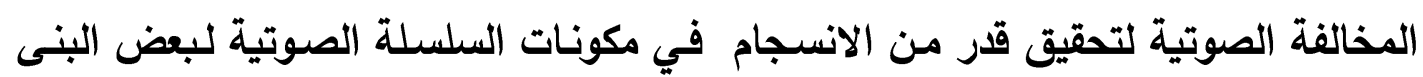
اللفوية.

\section{• - - إبدال الواومن الهمزة إذا انضم إليها هززة أخرى}

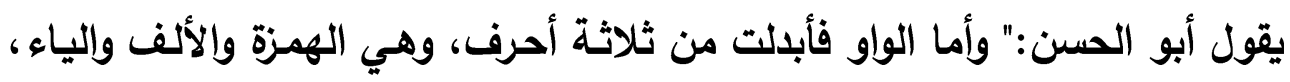

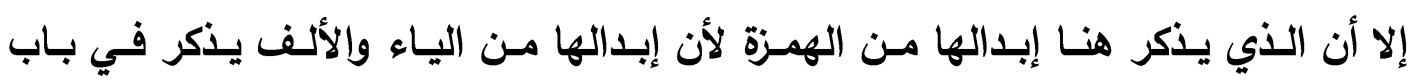




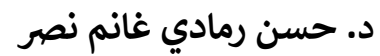

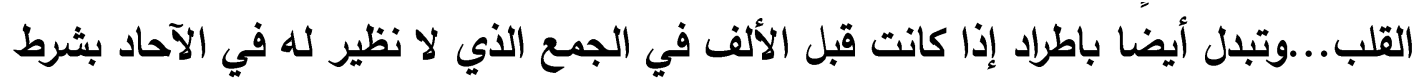

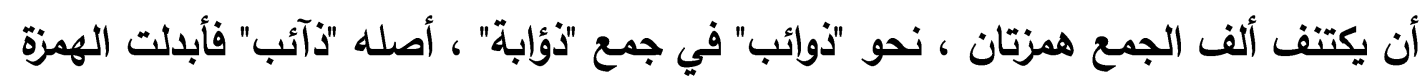

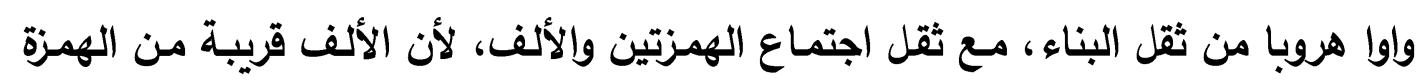

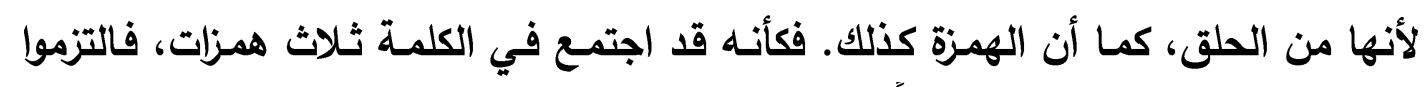

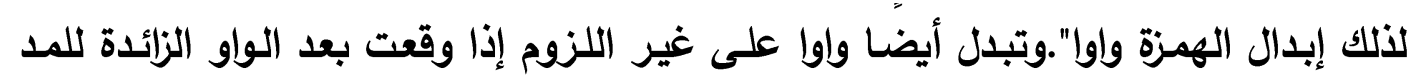

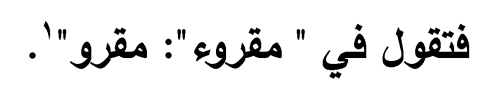

ويمكن القول سوهو رأي ابن عصفور في باب إبدال الواو من الهمزة -تبدل - أيضًا

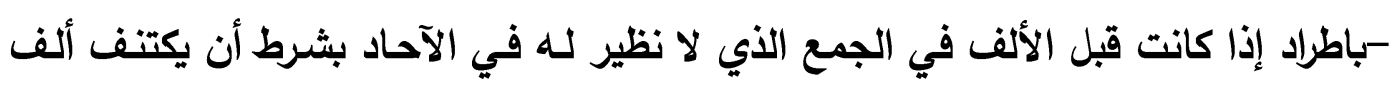

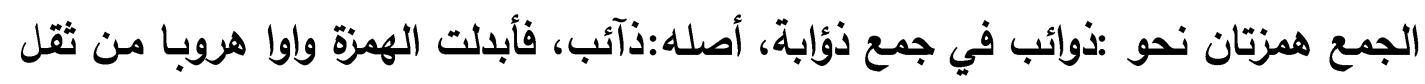

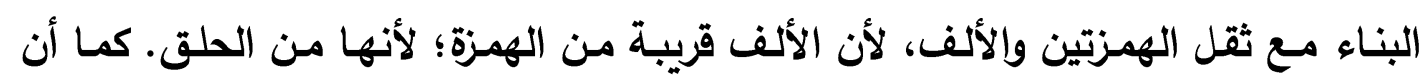

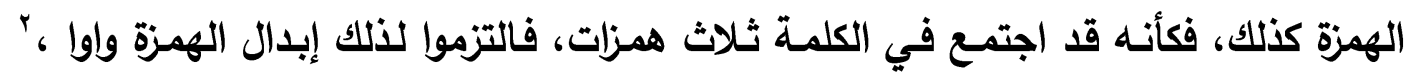

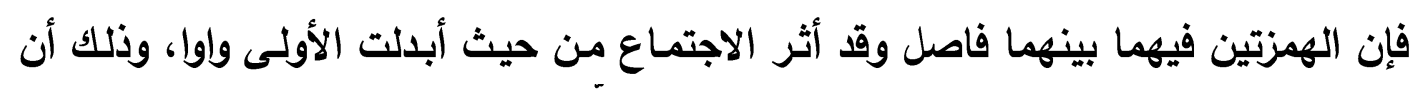

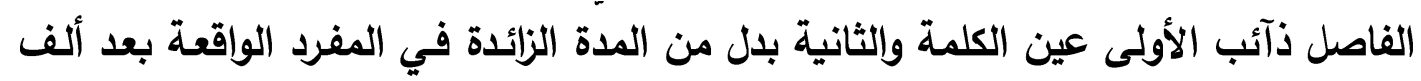

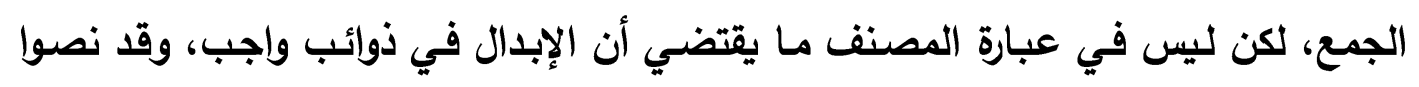

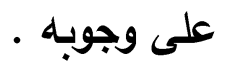

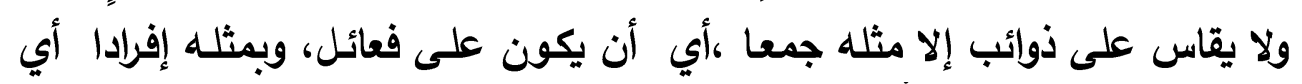

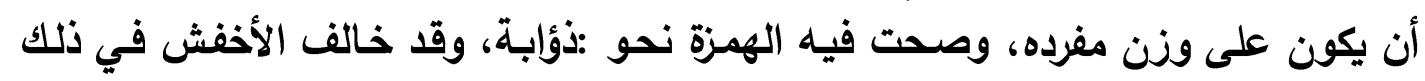

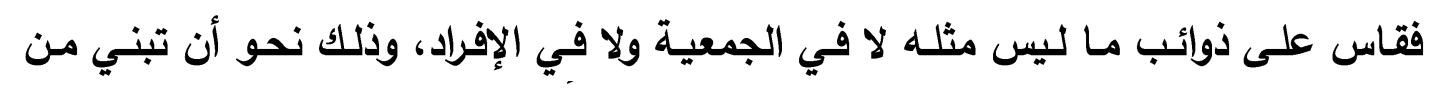

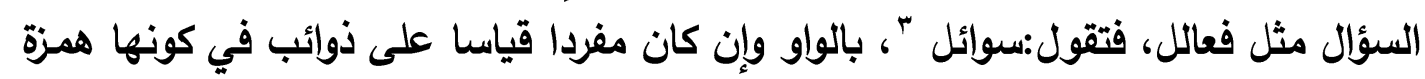

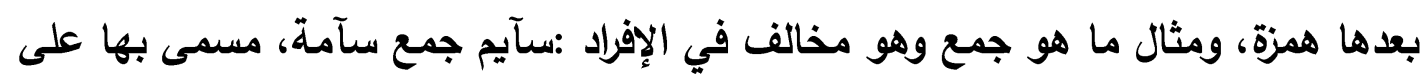

(l)

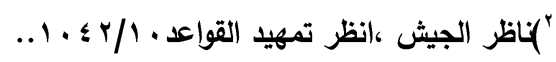

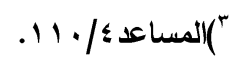

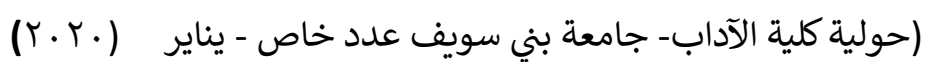


حد سحابة وسحائب، فيقول فيه الأخفش :سوايم، قياسا على ذوايب، وإن كان مفرده مخالفا

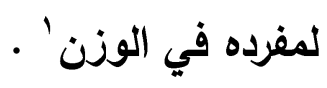

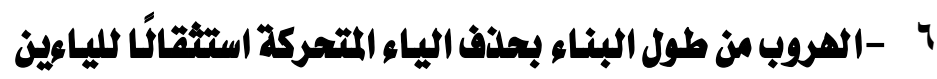

وفي ذلك يقول أبو الحسن:" ... ومن ذلك "فَيْلُوليةّ" فإِـها إن كان من ذوات الياء

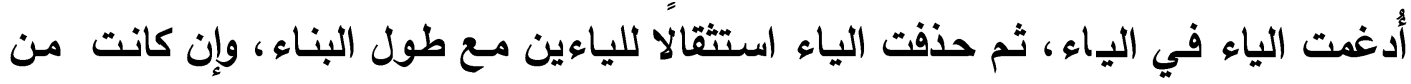

ذوات الواو قلبت الواو ياء، ثم أدغمت الياء في الياء ، ثم حذفت الياء المتحركةّ"..

ويمكن القول إنه التزم في "فَيُلولة" الحذف لأنـه قد بلـغ الغاية في العدد إلا حرفًا

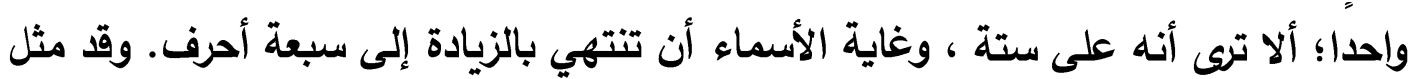

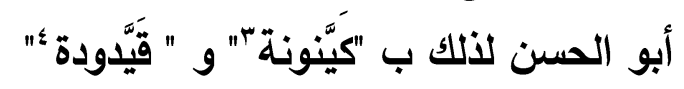

\section{ثالثما ؛ التخفيف بالمروب من اجتماع الأمثال}

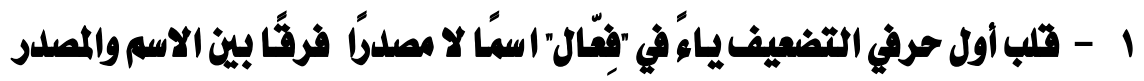

ذكر أبو الحسن أن الياء تبدل من الباء والراء والنون والـلام والصساد والضـاد والميم

والـدال والعين وكـاف والتـاء والجيم والههاء للتخلص مـن اجتمـاع الأمثال، والتخلص مـن التضعيف:" وأبدلت أيضًا من الباء على اللزوم في "ديباج" وأصلهه" دبَّاج" فأبلدوا البـاء 
الساكنة ياء هروبا من اجتماع المثلين ، والد ليل على ذلك قولهم في الجمع "دبابيج" فردوا الباء لمًا فرقت الألف بين المثلين'

وأبدلت من الراء على اللزوم في "قيراط" و" شيراز"؟ (قأبدلوا الياء من الراء الأولى

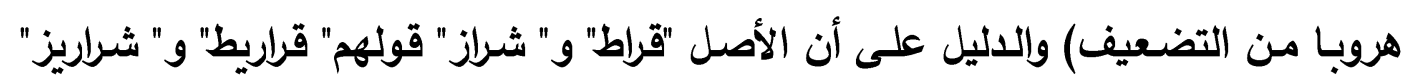
فردوا الراء لما فصلت الألف بين المثلين". وأبدلت من النون على اللزوم" في "دينار" أصله "دنّار" فأبدلت الياء من النون الأولى هروبا من ثقل التضعيف بدليل قولهم "دنانير" في الجمع و" دنينير" في التحقير .

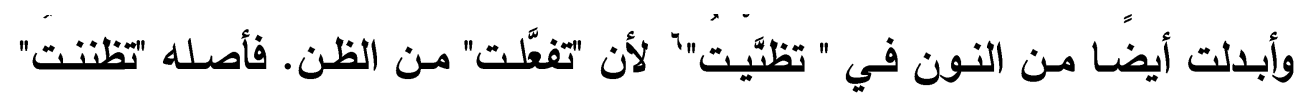
فأُبدلت النون ياء هروبًا من اجتماع الأمثال. v

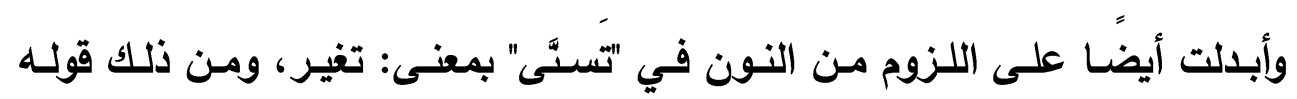

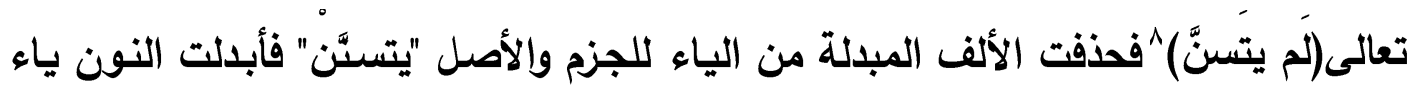

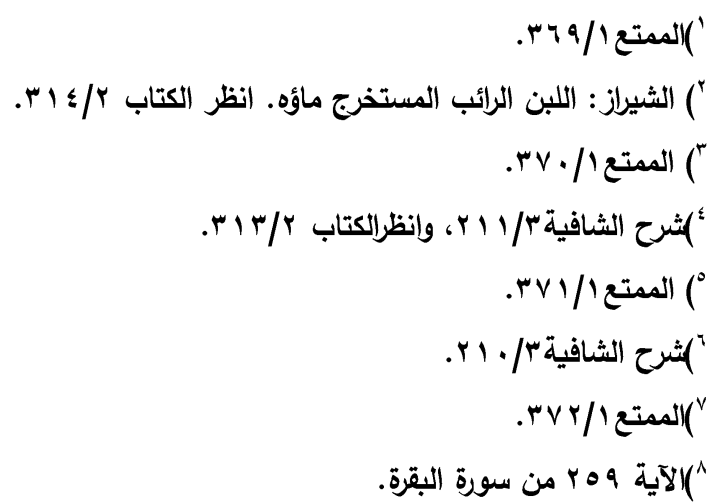

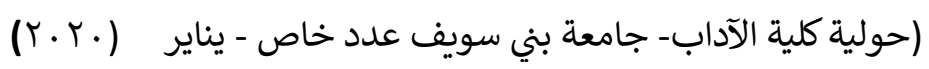




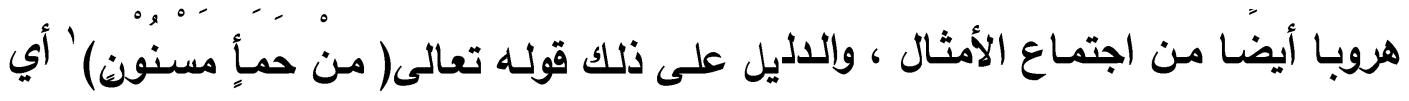

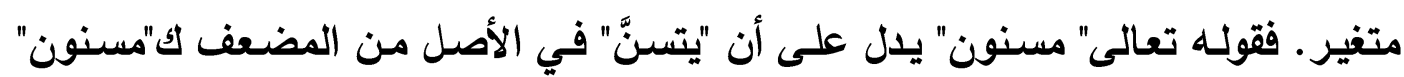
وليس من قبيل المعتل؟.

وأبدلت من اللام في" أمليت الكتاب"” إنما أصله "أمللت" فأبلالت التلام الأخيرة ياء

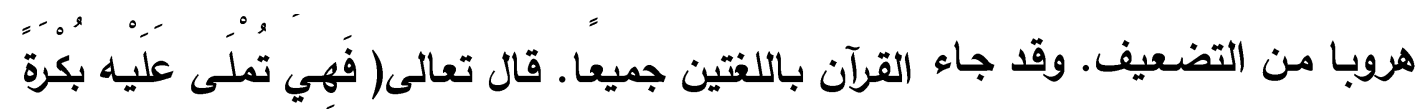

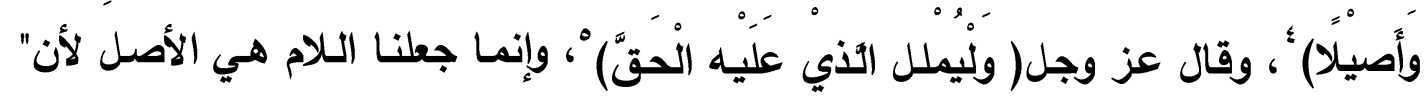

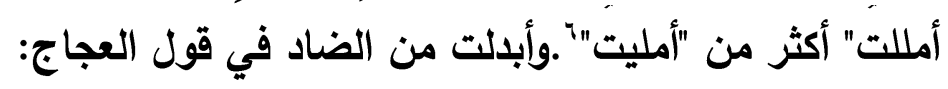

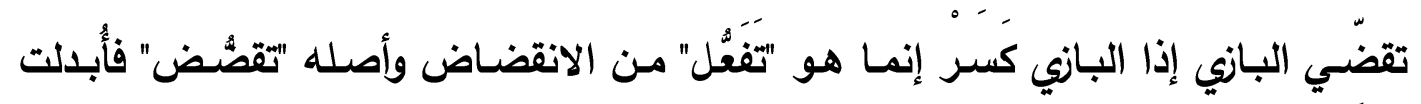

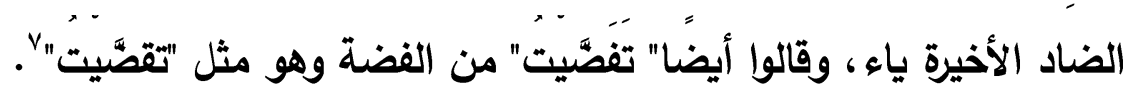

وأبدلت أيضًا من الميم الأولى في "أما" فقالوا" أيما" هروباً من التضعيف. وقد روي

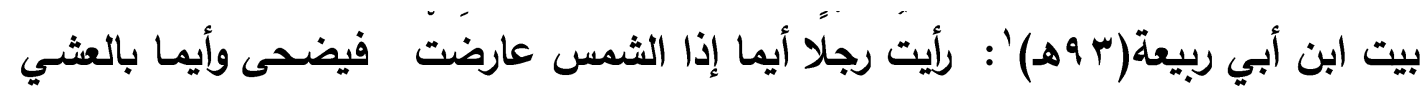
فيخصر

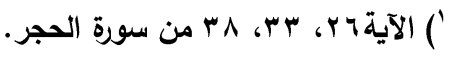

$$
\begin{aligned}
& \text { (4) }
\end{aligned}
$$

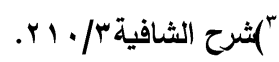

$$
\begin{aligned}
& \text { كالآلية ه من سورة الفرقان. }
\end{aligned}
$$

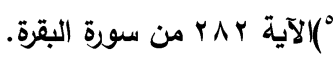

$$
\begin{aligned}
& \text { " } \\
& \text { (r) }
\end{aligned}
$$


وأبدلت أيضًا من الميم الأولى في" ديماس" هروبًا من التضعيف وأصله "دمساس"

بليل قولهم في الجمع "دماميس".

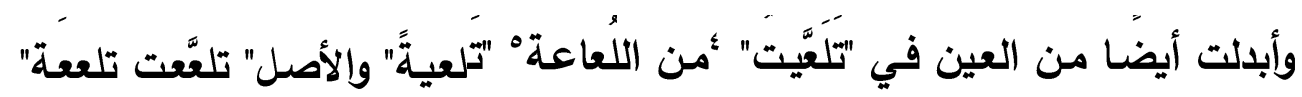
فأبدلت العين الأخيرة ياء هروبا من اجتماع الأمثال.

فإن قال قائل: فلعل" تلعيت":"تفَعَيت" والياء زائدة مثلها في" تجعبيت" فلا تكون إذ

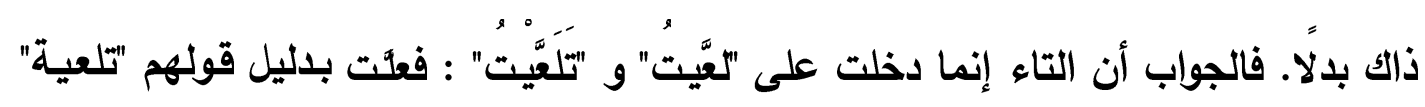

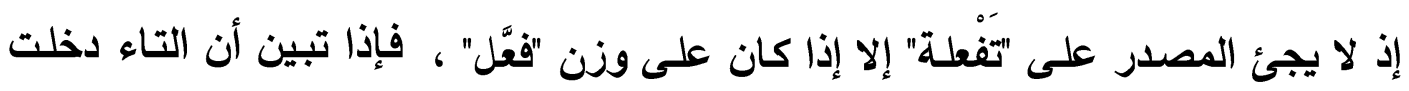

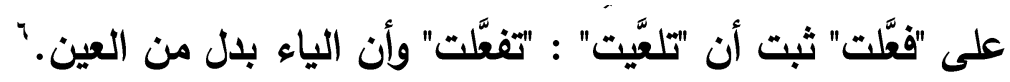

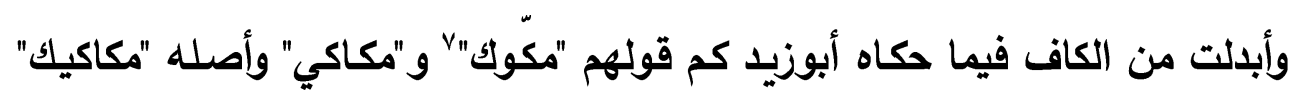

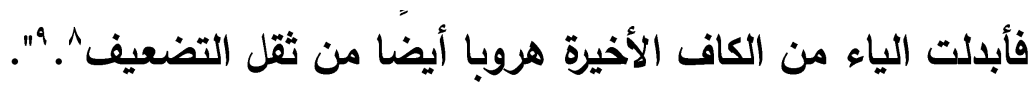

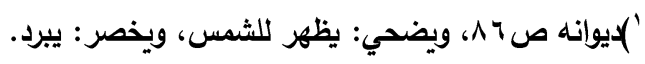

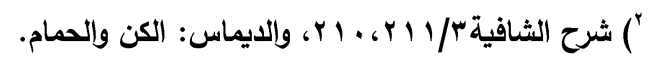

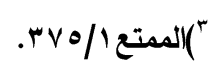
") تلعيت: رعيت. ")|للعاعة: أصل النبت.

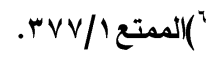
(المكزك: طاس يشرب به. ^يريد تكرار الكاف.

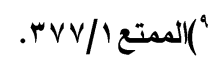


ويمكن القول إنه يقلب أول حرفي التضعيف ياء وجوبـا في مـا يجيء على "فَعال" اسما لا مصدرا فرقًا بين الاسم والمصدر ، فلا يكون هذا القلب في المصدر ، نحو" كذَب كدَابا" ، وشدُ-عند سيبويـه- قلب ثاني حرفي التضعيف ياء إذا وقع لامـا في الكلمـة ،نحو "أمليت" والأصل "أمللت" ، أو اجتمع في الكلمة ثلاثة أمثال أولهما مدغم في الثاني، وذلك

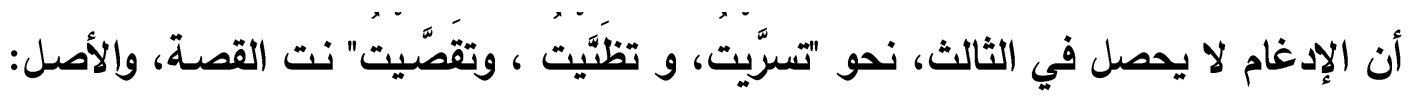

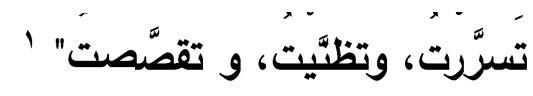
ولقد تناول علماء الأصوات المحدثين تناولوا هذه الظاهرة وأطلقوا عليها مصطلح المخالفـة Dissimulation وهـي عكس المماثلـة، أي جعل الصـوتين المتمــلين غيـر متماثلين، يتم بموجبها تغيير أحد الصوتين المتماثلين في الكلام إلى صوت آخر من أجل تجنب الصـوبة الناتجـة عن تكرار النطق بالصـوت الواحد. وحدثت المخالفـة في الأمثلـة المذكورة عن طريق قلب أحد الصوتين أي منهما ساكن في نهاية مقطع من البنى السـابقة إلى صوت الياء مما أدى إلى إضفاء الوضوح والانسجام بين الأصوات المتجاورة.

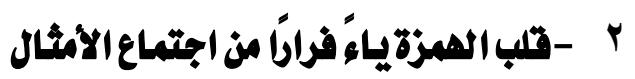

\section{-لام الجمع همزة(جيَّأو و جيايا)}

يزى أبو الحسن أن الهمزة تقلب ياء إذا وقعت بعد ألف الجمـع، وكانت تلك الهمزة

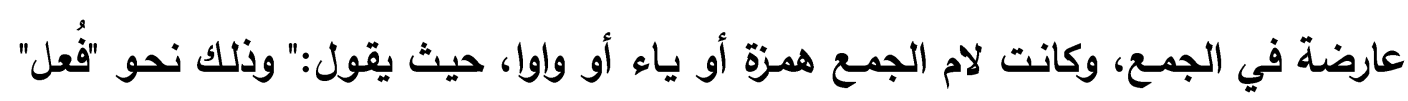




\section{د. حسن رمادي غانم نصر}

من المجيء نحو" جيَّأ" فِإنك تقول في جمعه" جيايا" والأصل" جيايئ" فاكتنف ألف الجمع ياءان، فقلبت الثانية همزة فقالوا "جيائئ ، فقلبت الهمزة الثانيـة يـاء لاجتماع الهمزتين وانكسار مـا قبل الثانية فقالوا" جيائي"، ثم حولوه إلى" جياءي" فتحركت الياء ومـا قبلها مفتوح فقلبت ألفًا ، فصار "جياءى"، وكان هذا التحويل لازما إذ كانوا قد يحولون في مثل " صحارى" مع أنه أخف من" جياءى" لأنه لم تعرض فيه همزة كما عرضت في" جياءى".وإنما لزم تحويله لما عرضت فيه الهمزة لأن عروضها تغيير، والتغيير يأنس بالتغيير، ثم قلبت الههزة ياء فصار "جيايا" ، وإنما لزم قلب الهمزة ياء لما وقعت بين ألفين لأن مخرج الهمزة يقرب من مخرج الألف ، فكان كالتقاء ثثلاث ألفات. وكذلك تفعل بكل ما تعرضُ فيه الهمزة

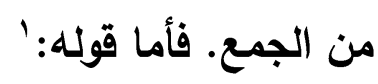
سماء الإلَه فَوق سبع سمائيا

فإنه رده إلى أصله كما ترد جميع الأثياء إلى أصلها عند الضرورة؟

') عجز بيت لأمية بن أبي الصلت. جاء خارجا عن الأصل من ثلاثة أوجه: أحدها :أنه جمع سماء على فَعايل، من حيث كان

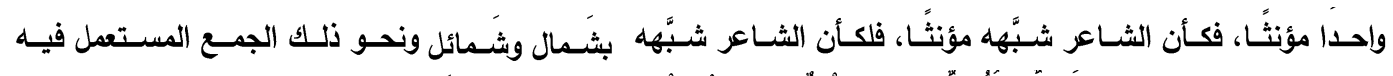

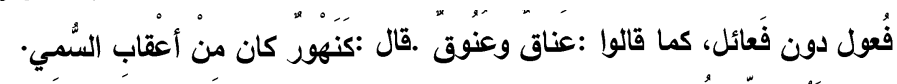

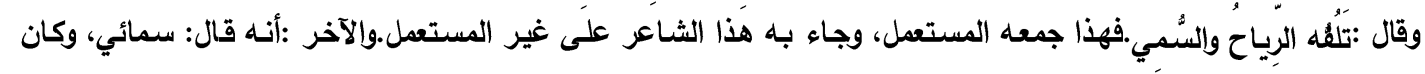

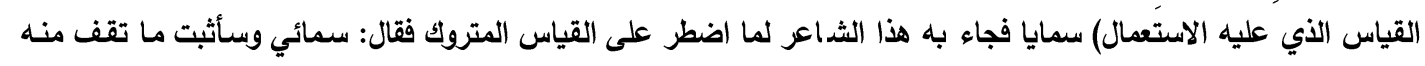

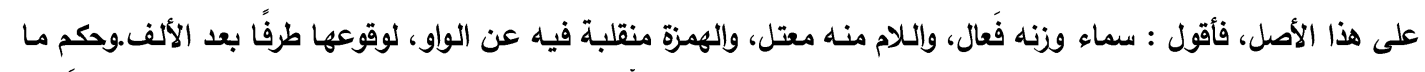

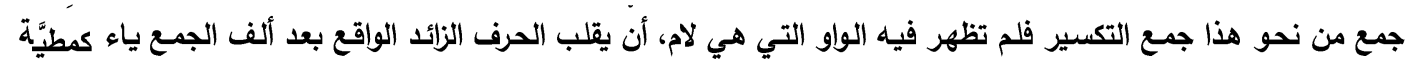

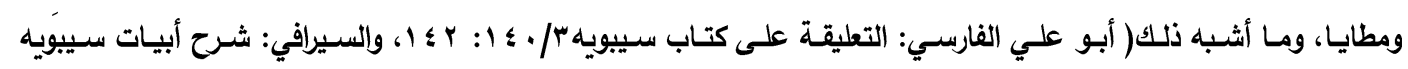

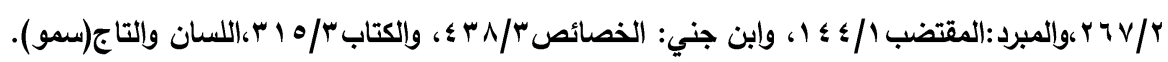

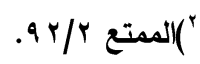


وعليه يمكن القول إن كان ثاني حرفي العلـة مبدلاً كالياء الثانية في " جيايا، سلم "و " جيايا " جمع " جيء " مثال " :عيل " من جئت أصله " :جيائي" ، ثم عومِل

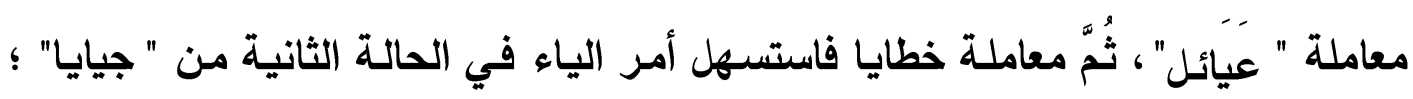
لأئَها مفتوحة وبلل من همزة، " فكان " تصحيحها كتصحيح واو " بويع." ولم يستسهل أمرها في الحالة الأولى؛ لأنَّها حينثًٍ مكسورة، وياء غير مبلدة من شيء، فلو انفصل ثانيهما

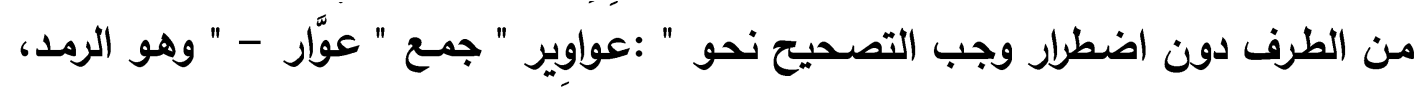

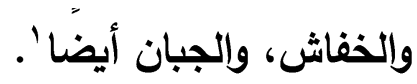

-لام الجمع منقلبة عن واو(مطية ومطايا)

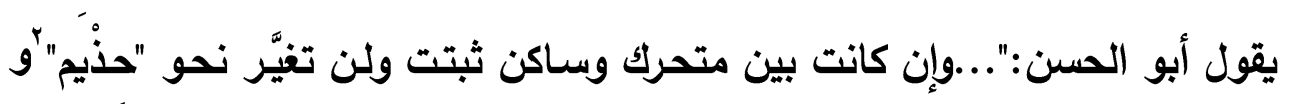
"حيفس" ما لم يكن الساكن ألف الجمع الذي لا نظير لـه في الآحاد، وتكون الياء ساكنة

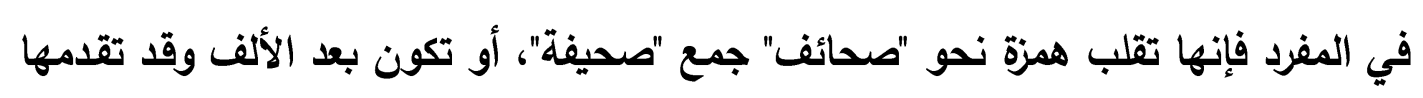

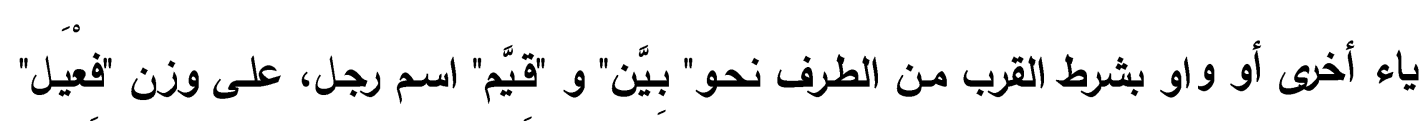

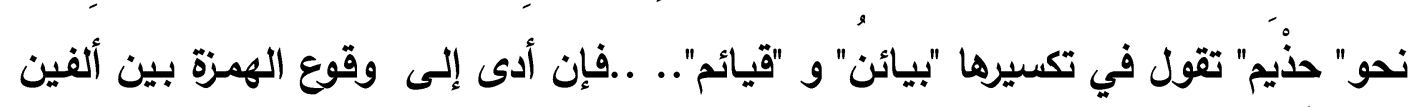

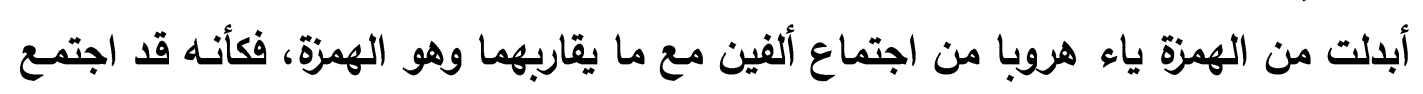

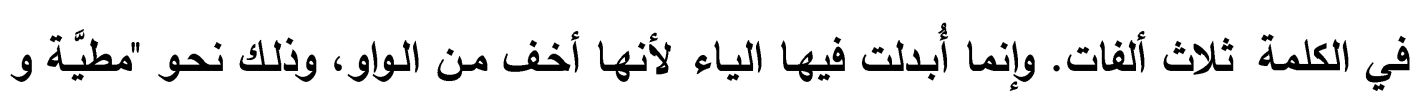


مطايا "أصله "مطائو"، ثم قلبت لتطرفها وانكسار ما قبلها فصار" مطائي" ، ثم قلبت الكسرة

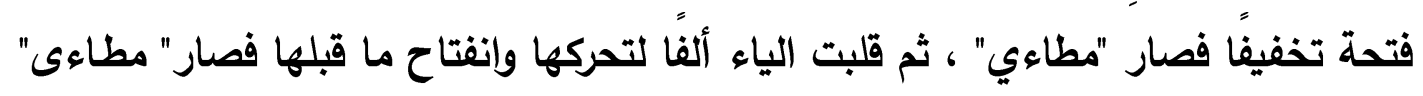

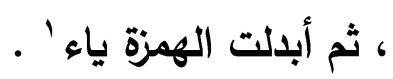

وكذلك تفعل بالهمزة المبدلة من الألف إذا أدى ذلك فيها إلى وقوع الهمزة بين ألفين نحو" صلاءة' وصلايا" ما لم تكن الواو من المفرد واوا ملفوظًا بها فإن الهمزة إذ ذاك تبدل واواً لتكون الواو ظاهرة في الجمع كما كانت في المفرد نحو "علاوة" و علاوى"، و" إداوة ؛ و

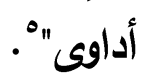

ويمكن القول إن أصل مطايا مطايو -لأن أصل مفرده وهو مطية مطيوة فعيلة من المطا وهو الظهر، أبدلت الواو ياء، وأدغمت الياء فيها على حد مـا فعل بسيد وميتفقلبت الواو ياء لتطرفها بعد كسرة كما في الغاني وإلاعي، ثم قلبت الياء الأولى همزةُ كما

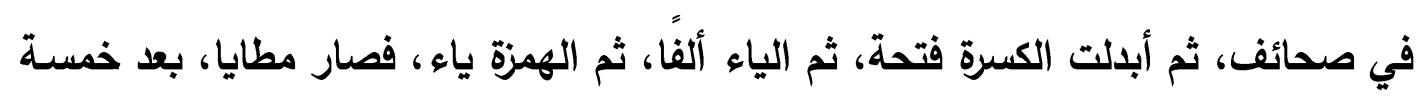

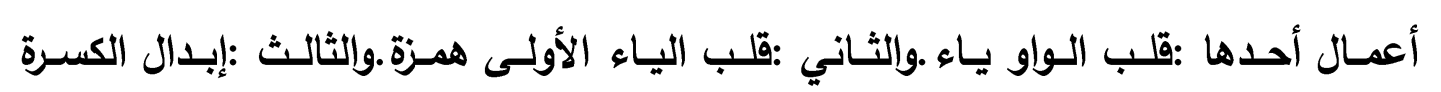

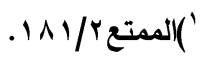

$$
\begin{aligned}
& \text { r) الصلاءة: مدق الطيب. }
\end{aligned}
$$

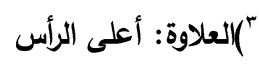

$$
\begin{aligned}
& \text { ") الإداوة: إناء صغير من الجلد يتخذ للماء. }
\end{aligned}
$$

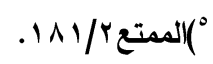


فتحة.والرابع :إبدال الياء ألفا.والخامس :إبدال الألف ياء، ولم يرجع إلى أصلها، لأن الواو أثقل من الياء، أو لأنها لما أعلت في المفرد أعلت في الجمع'.

\section{رابعًا : الاتقال من الثقيل إلى الغفيف}

\section{1 - مابب الياء واواً في الفمل المتل اللام \\ على ثلاثة أحرف مضموم العين(فعل)}

ذكـر أبـو الحسـن أن اليـاء تقلـب واوا إذا وقعـت لامــا لصـيغة(فَعل): "... وأمسـا

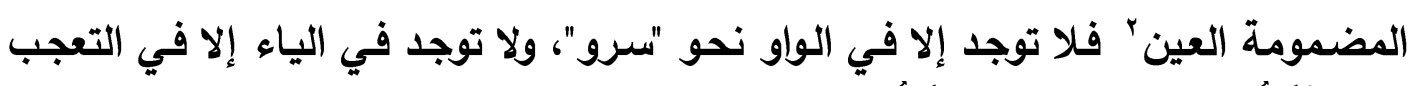

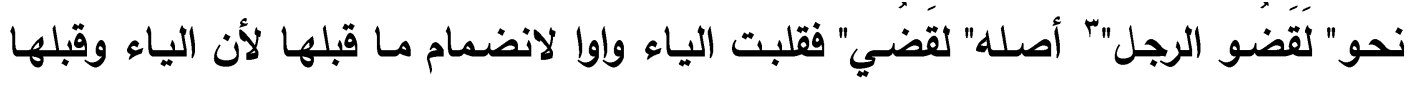

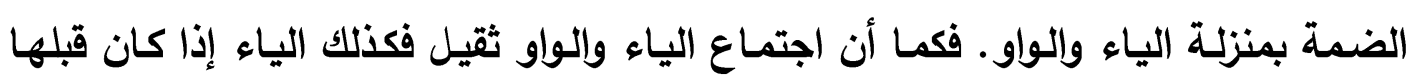

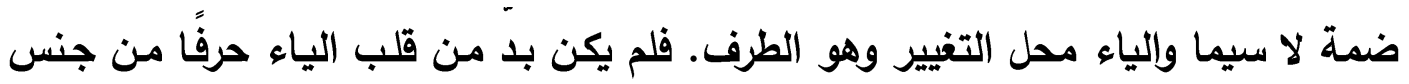

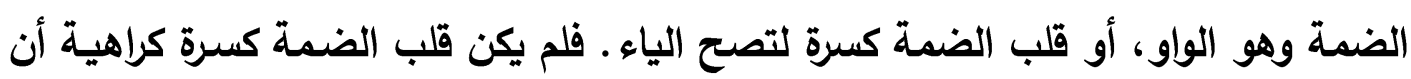

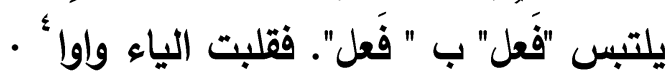
ويمكن تفسيرَ ذلك بالتالي:

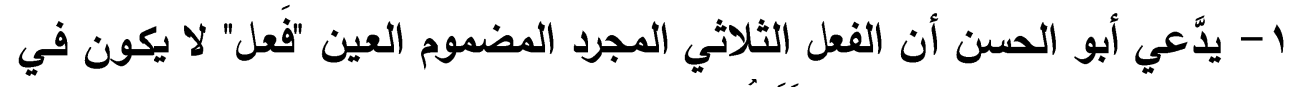

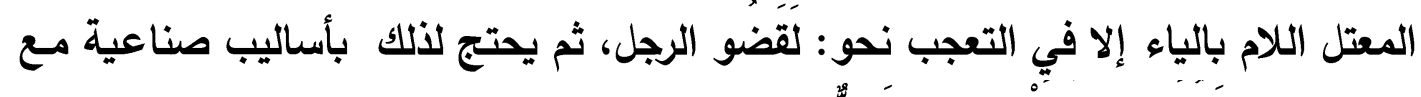

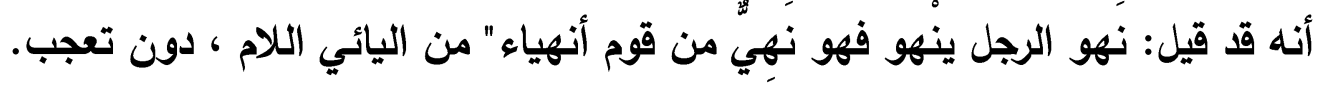

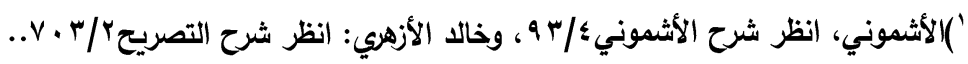

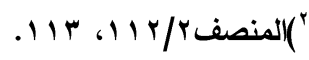

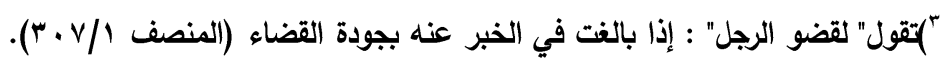

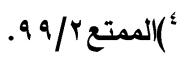




\section{د. حسن رمادي غانم نصر}

ץ- الفعل إذا كان صحيح العين والتلام، فأمره واضـح، يقال:حسن الوجه وجهك، ويجوز تسكين العين، كمـا يجوز ذلك في غير هذا الباب، وأمـا نقل حركـة العين إلى الفاء، فقالوا : إن أجريته مجرى نعم، جاز وإن أجريته مجرى فعل التعجب لا يجوز إلا إن

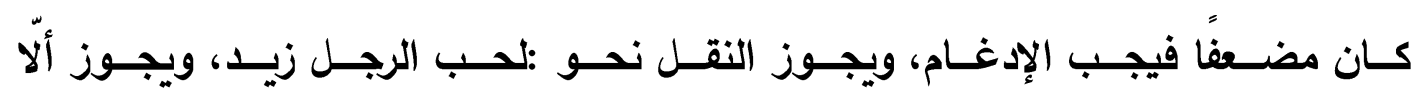
تنقل، فيقال :لحب الرجل، وإن كانت العين معتلة - فإنته يلزم قبلها ألفًا، لتحركها، وانفتاح ما قبلها، فيقال : لجار الرجل زيد، وإن كان معتل العين والتلام فإن كانا واوين، فإنك تقلب ضمة العين كسرة، والواو التي هي لام ياء، استثقاًاً للواوين، والضّمة، فيقال :لقوي الرجل عمرو، وإن كانت العين واوا، واللام ياء، قلبت الياء واوا لتطرفها وانضمام مـا قبلها.فيجتمع دئح حينئذ واوان وضمة، وتنقل الكلمة، فتقلب الضمة كسرة، وتعود الواو المتطرفة إلى أصلها، وهو الياء، فيقال :لثوي الرجل عمرو، وإن كانت لام الفعل واوا بقيت .فيقال :لغزو الرجل

وإن كانت لام الفعل ياء نحو: رمى، قلت :لرمو الرجل فتقلبها واوا لانضمام ما قبلها'

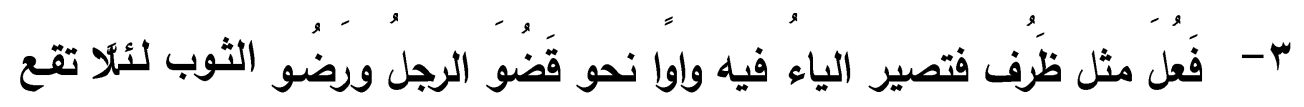

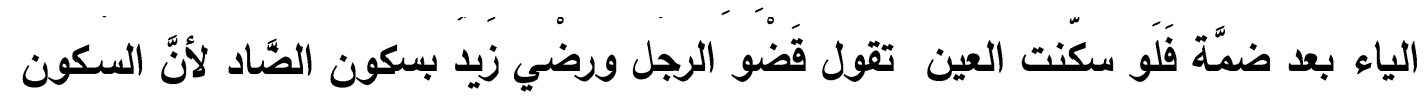

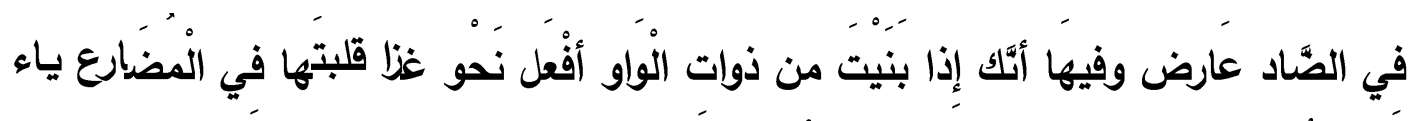

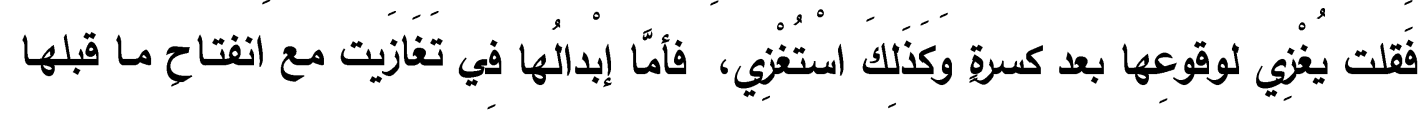

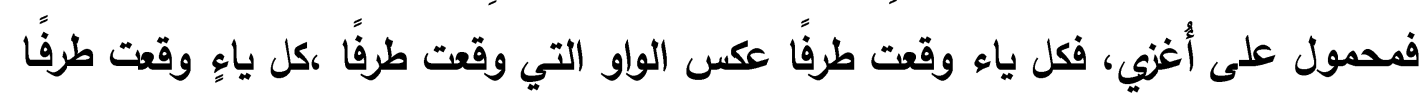
يعني لام الكلمة إثر ضم يعني قبلها ضمة وجب قلب الياء واوا. ')ناظر الجيش، انظر تمهيد القواعد بشرح تسهيل الفوائده/0مه، ب^ه.

( حولية كلية الآداب- جامعة بني سويف عدد خاص - يناير (F. ) 116 
ـ - ويمكن القول إن الناطق قلب نصف الحركة الضعيفة وهي الياء إلى نصف حركة أقوى منها وهي الواو، وإن كانت نصف حركة إلا أنها أقوى من الياء لأنها قريبة من الضمة الطويلـة التي تعد أثقل الحركات، ويبدو أن الضمة القصيرة أثرت في صوت الياء تأثيرا تقدميَّا فحولتها إلى نصف حركة قريبة من الضمة القصيرة، وهي نصف الحركة الواو ، وقد أدى هذا إلى إحداث تماثل بين الأصوات المتجاورة.

\section{r - امتناع بناءُ "فَفُلَ" من ذوات الياء}

يقول أبو الحسن:" فإن قيل: ولأي شيء امتنع بناء" فَعل" من ذوات الياء؟ فالجواب أن الذي منع من ذلك لأنهم لو فعلوا ذلك لأدى إلى الخروج من الخفيف إلى الثقيل لأنه يلزم فيه قلب الياء واوا، والياء أخف من الواو، مـع أنه يلزم أن يكون المضـارع على "يفْل" فكنت تقول "رمو يرمو" فيجتمع لك في الماضي والمضارع ضمة و واو، وذلك ثقيل، وليس كذلك ذوات الواو لأنه لا يلزم فيها أكثر من ثقل الواو والضمة نحو "سرو يسرو"، إذ ليس يلزم فيها خروج من خفيف إلى ثقيل"' .

ويمكن القول إنها ساغ ذلك في فعل التعجب لأنه لا مضارع له، فقلَّ فيه الثقل لذلك،

كما إنه يشبه الأسماء، ولذلك صححوا الفعل في نحو "ما أطوله" تشبيها له ب "أطول منه" 


\section{ب - امتناع الإدفام في الأفين والهمزتين}

إذا التقت الهمزتان في كلمة واحدة وجب قلب الثانية منعا للثقل، وذكر أبو الحسن منع إدغامهما إلا في ندو "سأل و رأس" فيقول:" اعلم أن كل مثلين قد يدغمان إلا الألفين

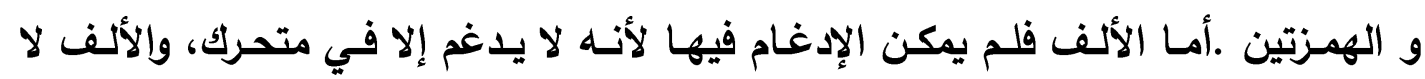
تتحرك. وأما الهمزة فثثيلة جدًا، ولذلك يخفقها أهل التخفيف منفردة، فإذا انضم إليها غيرها ازداد الثقل فألزمتّ إحد اهما البدل على حسب ما ذُكر في باب تسهيل الهمز فيزول اجتماع ولهي المثلين فلا يدغم إلا أن تكونا عينين نحو" ساًّ آل" و" رآّآس" فإنك تدغم ولا تبدل لما ذكرناه من أنك لو أبدلت إحداهما لاختلفت العينان، والعينان أبدا في كـلام العرب لا يكونـان إلا لـان مثلين."

ويمكن القول إنه يمتنع الإدغام في الهمزتين في غير نحو ساّال وجاّار والداّاث عند

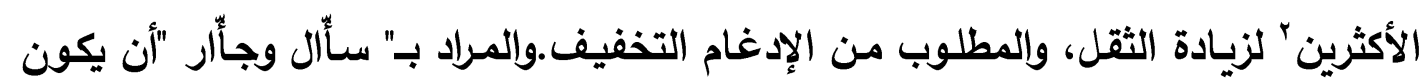

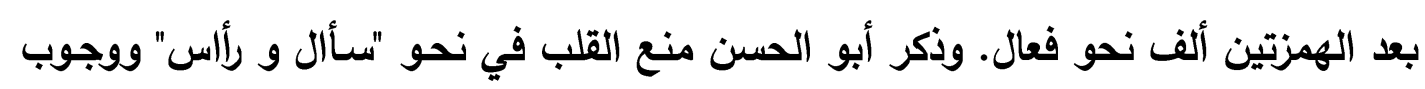
الإدغام كون الهمزتين عينـي الكلمـة لا يفصل الأولى السـاكنة عن فائها سـاكن، وشـرط الإدغام في الهمزتين-الأولى ساكنة والثانية متحركة- وقوع الهمزتين الملتقيتين وقع العين مع اتصال الاولى الساكنة بفاء الكلمة وإنما جاز إدغام الهمزتين فيه لوجود الألف بعدهما،

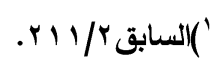

r) قد يجوز الإدغام في الهمزتين على ما حكي عن عب د الله بن أبي إسحاق الحضرمي ونـاس معه من أنهم كانوا يحققون

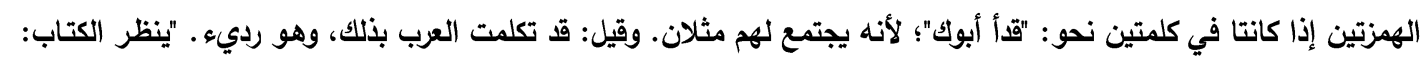

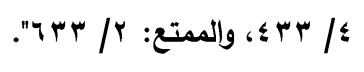

(حولية كلية الآداب- جامعة بني سويف عدد خاص - يناير (.r. ) 
والألف مسهلة من أمره، فيحصل تخفيف ما.والمراد بغير" سأال "ألا يكون بعد الهمزتين ألف. - 20 - n.

\section{ع - إدغام "الهاء" في "الهاء"}

يذهب أبو الحسن إلى أنها متى اجتمعت الهاء مـع الحاء وكانت الهاء أولاً جـاز الإدغام والإظهار، ويكون الإدغام بقلب الأول إلى جنس الثاني، فتقلب الهاء إلى حاء وتدغم في الحاء، وذلك لأنهما متقاربان في المخرج والصفة، وقد قلب الأول إلى جنس الثاني، حيث يقول: "فإذإ اجتمعت مـع الحاء فلا يخلو أن تتقدم الحاء أو تتقدمها الحاء. فإن تقدمت على الحاء جاز الإدغام والبيان ، نحو" اجبه حاتما" إن شئت لم تلدغم، وإن شئت قلبت الهاء حاء وأدغمت الحاء في الحاء فقلت" اجبحاتمـا" لأنهما متقاربان ليس إنس بينهما شيء ، إلا أن الحاء من وسط الحلق ، وهما مهموسان. وإنمـا قلبت الأول إلى جنس الثاني ولم تقلب الثاني إلى جنس الأول لأن الذي

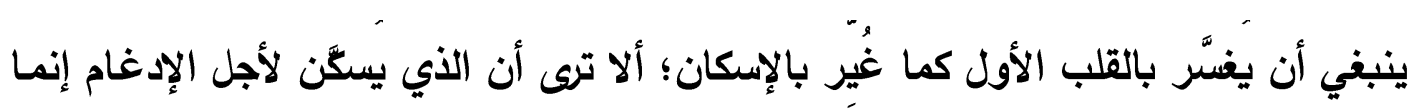

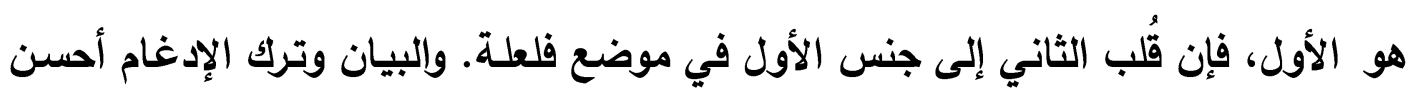
لاختلاف المخرجين، ولأن حروف الحلق بأصل للإدغام لقلتها والتصرف بابه أن يكون فيما 


\section{د. حسن رمادي غانم نصر}

وإن تقدمتها الحاء نحو" امدح هلاًا" فالبيان ولا يجوز الإدغام، و العلة في ذلك أن

المخرجين قد اختلفا مع أن الإدغام في حروف الحلق ليس بأصل.

وأيضًا فإنك لو أدغت لوجب أن تقلب الأول إلى الثاني على أصل الإدغام فكنت

تقلب الحاء هاء ، وذلك لا يجوز لأن الهاء أدخل في الحلق من الحاء، ولا يقلب الأخرج إلى الفم إلى جنس الأدخل في الحلق. والسبب في ذلك أن حروف الفم أخف من حروف الحلق، ولذلك يقل اجتماع الأمثال في حروف الحلق، وما قرب من حروف الحلق إلى الفم كان أخفَّ من الأي هو أدخل منه في الحلق، فكرهوا لذلك تحويل الأخرج إلى جنس الأخل لأن في ذلك تثقيلًا.

فإن أردت الإدغام قلبت الهاء حاء، وأدغمت فقلت" امدحِّلاً".وجاز قلب الثاني لما تعذر قلب الأول، وليكون الإدغام فيما هو أقرب إلى حروف الفم التي هي أصل للإدغام'". ويمكن القول إن :

1- كـلَّا من الهاء وإلحاء يتصفان بالهمس، والهاء أدخل في الحلق من الحاء فقلب الأدخل إلى الأخرج وهذا أصل إدغام المتقاربين، ومما أيداء هذا القلب أن صوت الهاء وقع ساكناً في نهاية مقطع فضعف بالسكون والموقع، في حين وقع صوت الحاء متحركًا في بدايـة مقطع فقوي بالحركـة و الموقعيـة، فقد حدث أن قلبت الهاء إلى حاء لإجراء التماثل بين الصوتين المتجاورين ، وهنا أثر الصوت الثاني في الصوت الأول تأصرا رجعيَّا. 
r- الهاء تدغم في الحاء سواء وقعت الهاء قبلها أو بعدها، فمثال الهاء قبلها قولك:في اجبه حاتما اجبحاتما، ومثال الهاء بعد الحاء قولك في اذبح هذه :اذبحاذه، فقلبوا الثاني إلى لفظ الأول عكس باب الإدغام، لأنهم لو قلبوا الأول إلى الثاني لقلبوا الحاء هاء وأدغموها في الهاء فكان يؤدي إلى إدغام الأدخل في الفم وهو الحاء في الأدخل في الحلق وهو الهاء ، ولا يـدغم في الهاء إلا مثلها نحو :اجبه هـلالا، وأدغمـت الهاء في الحـاء لتقاربهما في المخرج؛ لأن الهاء من أول الحلق والحاء من وسطه' r- البيان أحسن لاختلاف الحرفين، وأن حروف الحلق ليست بأصل للإدغام ، والإدغام عربي حسن لقرب المخرجين، وأنهما مهموسان.

\section{0 - معدم جواز إدفام الماء في المين مباشرةة}

يقول أبو الحسن: "فإن اجتمعت مـع العين فالبيان -تقدمت العين أو تأخرت- ولا يجوز الإدغام إلا أن تقلب العين والهاء حـاء، ثم تـدم الحاء في الحاء، وذلك نحو"

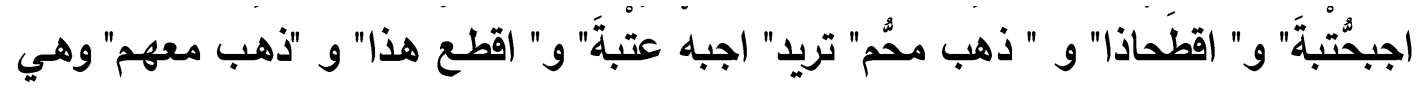
مثيرة في كلام بني تميم. وإنما لم تدغم إلا بتحويل الحرفين لأنك لو قلبت العين إلى هاء كنت قد قلبت الأخرج إلى جنس الأدخل.

ولـو قلبت الهاء إلى العين لاجتمـع لك عينـان، وذلك ثقيـل لأن العين قرببـة مـن الهمزة، فكما أن اجتماع الهمزتين ثقيل فكذلك اجتماع العينين. وأيضًا فإنها بعيدة من الهاء 


\section{د. حسن رمادي غانم نصر}

لأنها ليست من مخرجها، وتباينها في الصفة لأن العين مجهورة والهاء مهموسـة، والعين بين الثدة والرخاوة والهاء رخوة. فكرهوا أن يقلبوا واحدة منهما إلى الأخرى للتباعد الذي بينهما ، فلذلك أبدلوا منهما الحاء لأن الحاء من مخرج العين ، وتُقارب الهاء في الهمس

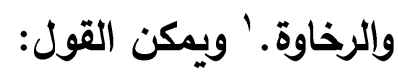

ا- لم يدغموا الهاء في العين، وإن اشتركتا في حروف الحلق لأنها خالفتها في

الهمس والرخاوة، ولأن العين لم يدغم مـا هو من مخرجها فيها وهو الحاء فبعد إدغام مـا ليس هو من مخرجها فيها مع ضعف الإدغام في حروف الحلق في لغة على قوم وخفف عليهم النطق به، وقل في لغة أخرى واستثقلها ، فالحاء أخف من العين، وإن كانـا من مخرج واحد؛ لأن الحاء مهموسة وهي رخوة والهمس والرخاوة‘ ץ- إذا اجتمع العين والهاء جاز قلبهما حاءين وإدغام الحاء في الحاء نحو قولك في معهم واجبه عتبة :محم واجبحتبه، لأنهم لو أدغموا الهاء في العين بقلب الهاء عينا، لأدى إلى الإدغام في العين مع شبهها بالهمزة وهو مستكره، ولو أدغموا العين في الهاء بقلب العين هاء لأدغموا الأدخل في الفم في الأدخل في الحلق، فلما كان كذلك واثتد تقاربهما وعسر النّق بهما قلبوهما جميعا إلى حرف يقاربهما، ولا يلزم منه شيء من ذلك

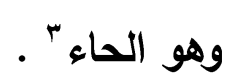

$$
\begin{aligned}
& \text { (l) }
\end{aligned}
$$

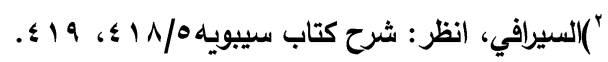

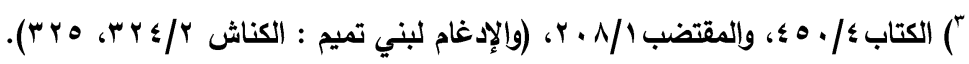

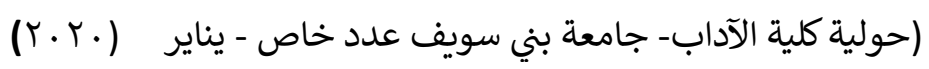




\section{צ-علم إدفام المثلين في أول الكلمة وجواز حلف أحدهما إذا كان الثاني زائلاً في نحو}

\section{"تتذكَر"وجواز الإدفام وعلم جواز حذف الثاني إذا كان أصليًّا}

من صور التخلص من توالي المثلين عند إلحاق تاء المضارعة في أول صيغ: تفعل، تفاعل، تفعلل، إذ يتوالى فيها تاءان، فيجوز التخلص من ذلك التوالي بالاقتصار على إحدى التاءين ،ويرى أبو الحسن جواز الإظهار والإدغام في نحو "تتابع" ، وجواز الإظهار والحذف في نحو "تتذكَر" ، حيث يقول: "أو يكون أحد المثلين في أول الكلمـة أو تـاء" افتعل". فإن كان أحد المثلين في أول الكلمة فإنه لا يخلو من أن يكون الثاني إذ ذاك زائدا أو غير زائد. فإن كان زائدا لم تدغم نحو "تتذكر" أنك إذا استثقلت اجتماع المثلين حذفت الثاني فقلت "تذكر" لأنه زائد وليس في حذفه لبس. وإن كان الثاني أصليَّا فإن شئت أدغمت

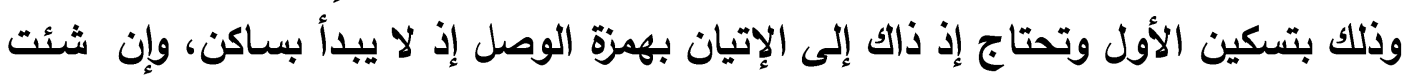
أظهرت ، وذلك نحو "تتابع" و "اتابع". فإن قيل: ولأي شيء لم تحذف إحدى التاءين كما فعلت في تذكر" فالجواب أن التاء هنا أصل فلا يسهل حذفها. وأيضًا فإن حذفها يؤدي إلى الالتباس ، ألا ترى أنك لو قلت "تابع" لم يدر أهو "فاعل" في الأصل أو "تفاعل" فإن قال قائل: فلائي لم يدغم في "تتذكر" وأمثاله؟ فالجواب أن الذي منع من ذلك شيئان: أحدهما أن الفعل ثقيل ، فإذا أمكن تخفيفه كان أولى، وقد أمكن تخفيفه بحذف أحد المثلين، فكان ذلك اولى من الإدغام الذي يؤدي إلى جلب زيـادة. والآخر أنه لو أدغمت لاحتجت إلى الإتيان بهمزة الوصل، وهمزة الوصل لا تدخل على الفعل المضارع لاسم الفاعل أصلًَا كما لا تدخل 


\section{د. حسن رمادي غانم نصر}

على اسم الفاعل ، وليس كذلك "تتابع" أنه ماض، والماضي قد تكون في أولهه همزة الوصل نحو" انطلق" و "استخرج" و "احمر" "'

ويمكن القول إن تصدر المثّلان أصلين أول كلمة، ففي الاسم نحو : ددن لا في الفعل، أو الثاني زائد نحو :تتذكر فلا إدغام، ويجوز حذف الثانية على مذهب البصريين والأولى على مذهب الكوفيين، أو أصل، وأدى إلى اجتلاب همزة الوصل في المضارع نحو تتـابع فـلا يجـوز الإدغـام، والمحذوف الثانيـة أي تتـابع وتتبع، جـاز الإظهار وجـاز الإدغام، باجتلاب همزة الوصل فتقول :اتابع واتبع، نحو: اتَبَع، وإتَذذ، واتَّعد، وائَقى، مالا يجوز فيه إلا الإدغام خلافًا لما قرر ابن عصفور لأنه جعل القيد أن يكون أحد المثلين تاء افتعل، ولو قيده بأول المثلين لقطع دابر الإثكال.

وإن كان مضارعا لا يحتاج إلى همزة الوصل جاز الإدغام ،إن شئت أسكنت الأولى

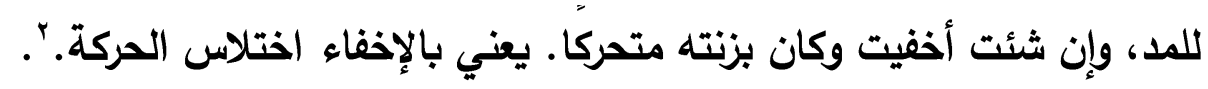

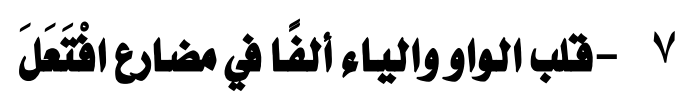

ذكر أبو الحسن أن الياء تقلب ألفاً:" وأمسا الياء إذا وقعت فاء فلا تقلب إلا أن تقع

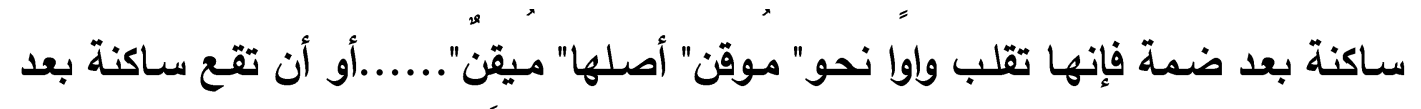




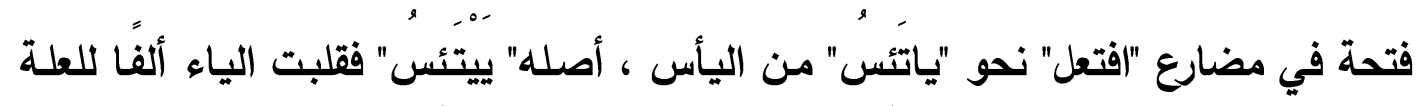

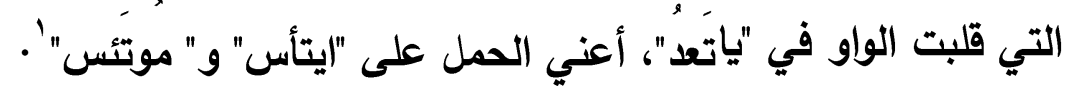

ويمكن القول إن سبب قلب الواو والياء ألفًا إذا تحركتا وانفتح مـا قبلهما كراهـة

اجتماع الأمثال ، أو كراهة اجتماع ثلاثة أشياء متجانسـة، وهي: الفتحة ، والواو أو الياء، وحركة الواو أو الياء، نظرا لوجود شبه قوي بين الواو والياء وبين الحركات، إذ إن في حروف اللين مضارعة للحركات حسب تعبير القدماء؟؟

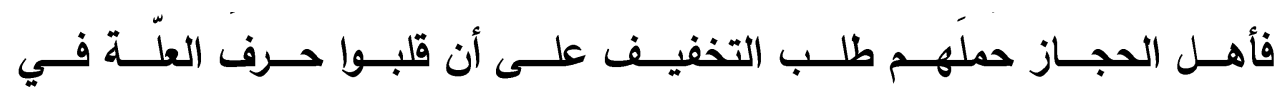

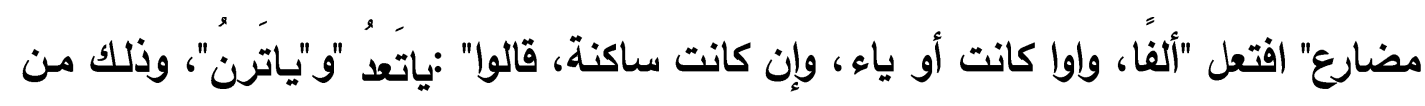

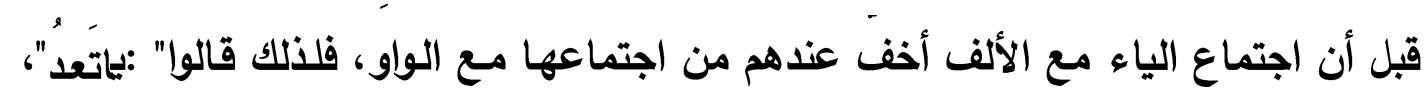
فأبدلوا من الواو الساكنة ألفًا، كما أبلوها من الياء في" ياتسرُّ."

قالوا: يأَتِيس، فجعلوها أي الياء بمنزلتها، أي بمنزلة الواو، إذا صارت الياء بمنزلة

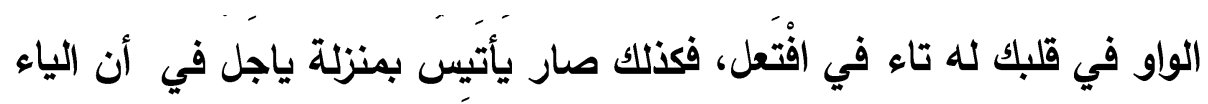
التي هي فاء قلبت ألفاء، كما قلبت الواو ألفاً من يأجلّا.

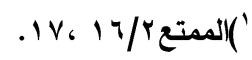

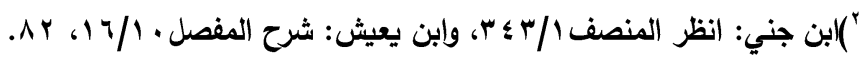

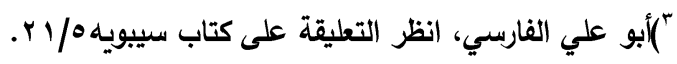




\section{د. حسن رمادي غانم نصر}

وهنا وقعت كل من الواو والياء -بوصفهما نصفي حركة ضعيفين في ذاتهما -في نهاية كقطع متوسط مغلق ، فضعفا بالموقعية، وقد سبقا بفتحة قصيرة كونت معهما فتحة مزدوجة، فأراد الناطق أن يتخلص من مثل هذه الحركات لصعوبة النطق بها، فوقعت كل من الواو والياء الساكنتين الضعيفتين تحت تأثير الفتحة القصيرة السابقة عليها فحولتها إلى جنسها ، فكونت مع الحركة السابقة عليها حركة طويلة (الألف).

\section{1 - إشباع معتل العين}

ذكر أبو الحسن أن الواو والياء تقلبان إلى الألف إذا وقعت كل منهما متحركة ومـا قبلها مفتوح، ويم ذلك في الكلمات الجوفاء والناقصة: "إن كان الفعل مبنيَّا للفاعل فإن الفعل من ذوات الواو يكون على "فَعَل" و "فَعل" و" فَعلُ" بضم العين وفتحها و كسرها. ف" فَعل" :

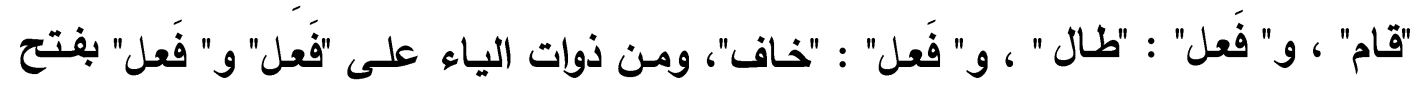

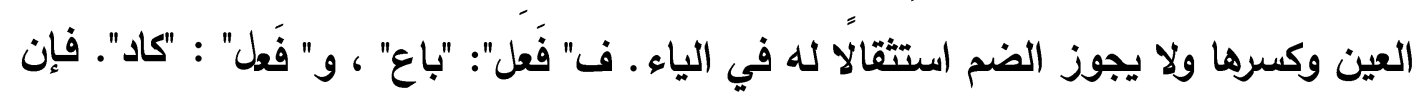

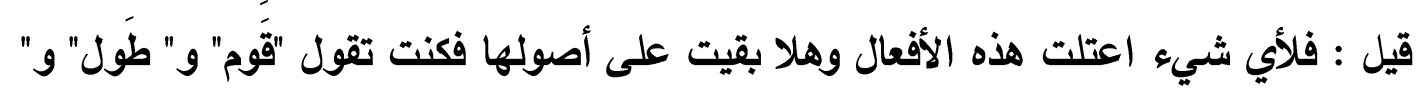

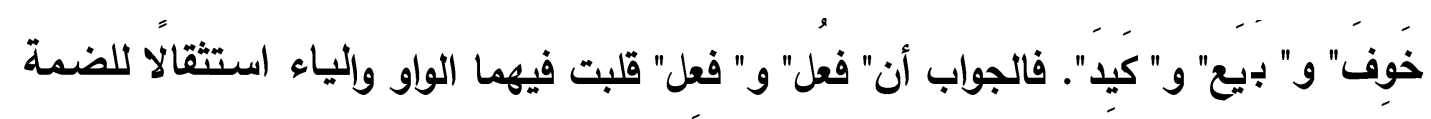

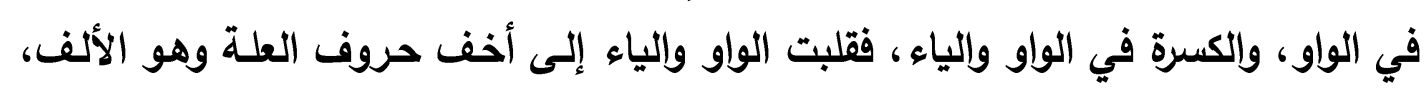
ولتكون العينات من جنس حركة الفاء وتابعة لها. 
وأما "فَعل" فقلبت الواو والياء فيها ألفًا لاستثقال حرف العلة مـع استثقال اجتماع المثلين، أعني: فتحة الفاء وفتحة العين. فقالوا في "قَوم" و "بيع" : "قام" و"باع" فقلبوا الواو

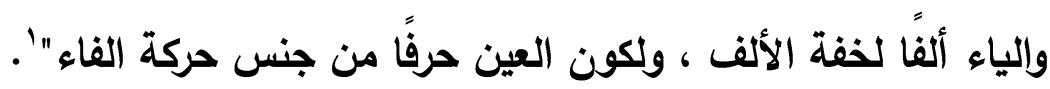
ويمكن القول: إن ابن عصفور علل هذا القلب بتفريق بين ما كان منهما-أي الواو

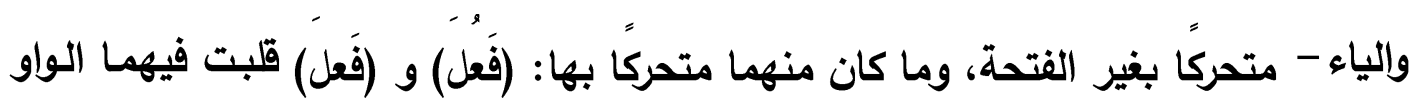

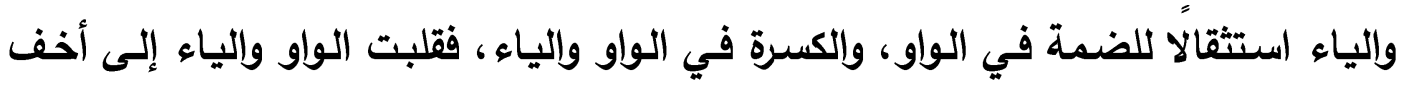
حروف العلة وهو الألف، ولتكون العينات من جنس حركة الفاء وتابعة لها. (فَعل) قلبت الواو والياء فيهـا ألفًا لاستثثقال حرف العلـة ، مـع استثقال اجتمـاع المثلين، أي فتحة الفاء وفتحة العين، فقالوا في "قَوم" و "بيع" : "قام" و"باع" فقلبوا الواو والياء ألفًا لذفة الألف ، ولتكون العين حرفًا من جنس حركة الفاء.

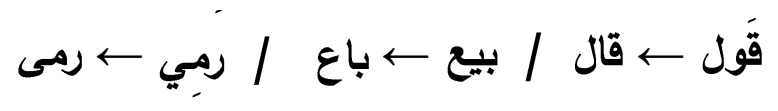

وقعت كل من الواو واليـاء، وهمـا نصف حركة بين حركتين قصيرتين، فاستثقل النطق بنصف الحركة الواقعة بين حركتين مما أدى إلى سقوطها ،فالتقت الفتحة القصيرة العابقة على نصف الحركة والفتحة القصيرة اللاحقة لها فكونتا الفتحة

$$
\text { طَول }
$$




\section{د. حسن رمادي غانم نصر}

وقعت الواو والياء بوصفهما نصفي حركة بين مصوتين مما زاد في ضعفهما ، لكن

هنا المصوتان ليسا من جنس واحد، فحركة نصف الحركة تخالف الحركة السابقة عليها.

$$
\text { وينطبق ذلك على المصادر : إقوام — إقامة / استقوام — استقامة }
$$

\section{9}

$$
\text { (كسر الفاء كراهية الواو في الجمع ولم تقلب في المفرد) }
$$

تسلم الياء من القلب في "فُعل" جمـع "أفْعل و فَعلاء" ، تحو "أبيضُ و بيضاء" ،

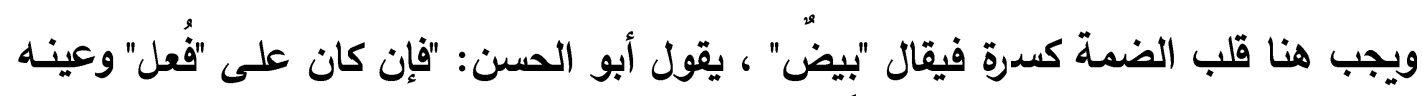

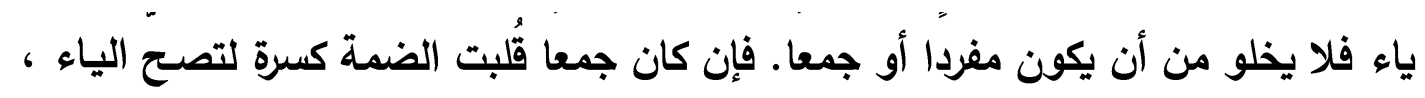
نحو "أبيض و بِيض" أصله "بيض" ك "حمر" فقلبت الضمة كسرة، وذلك أن الياء لمـا كانت تلي الطرف عوملت معاملة الطرف. فكما أن الياء إذا كانت طرفًا وقبلها ضمة تقلب الضمة

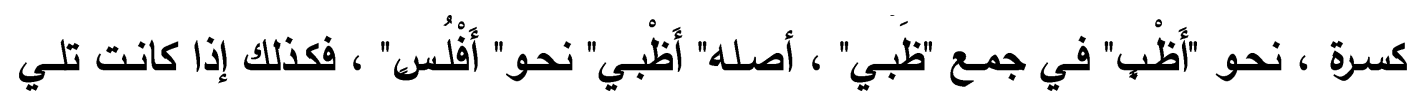
الطرف، لا خلاف بين النحويين في ذلك. وإن كان مفردا فحممه عند سيبويه والخليل كحمم الجمع. فإذا بنيت من البياض اسما على

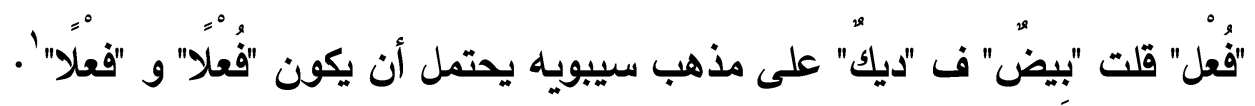
وأبو الحسن يقلب الياء واوا ويقرُ الضمة فيقول "بوضٌ" ولا يكون "ديك" عنده إلا

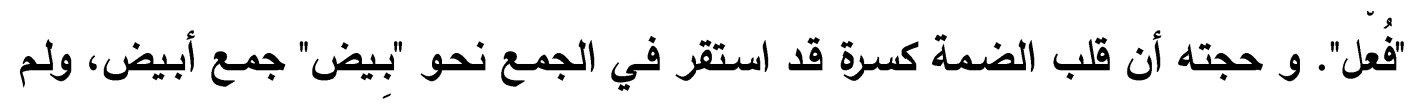


يسـتقر في المفـرد ،والقيـاس يقتضـي التفرقة لأن الجمـع أثقـل مـن الواحـد، فهـو أدعـى للتخفيف ، فلذلك قلبت الضمة كسرة في الجمع لتصح الياء، ولم تقلب الياء واوا لأن الياء أخف من الواو، وأما المفرد فلكونه أخف من الجمع يحتمل فيه الواو' .

والصحيح مـا ذهب إليه سيبويـه بدليل مـا ذكرنـاه في "مبيع" وأمثاله، من أنـه لمـا اجتمـع سـاكنان وحذفت الواو -على مذهب سييويـه جاءت الياء سـاكنة وقبلها ضمة تلـي الطرف فقلبت الضمة كسرة لتصح الياء. فكذلك في "فُعل" من الياء ينبغي أن تقلب الضمة كسرة لتصح الياء. فأما قوله'ب أُشَمر حتى يَنْفَ الساقَ مَئزري وكنت إذا جاري دعا لمضوفَةٍ فقلب الياء من "مضُوفة" وإوا ،وأقرَّ الضمة مـع كون الياء تلي الطرف لأن الأصل "مضْيفةٌ" لأنه من" ضاف يضيف"، ثم نقلت الضمة إلى السـاكن قبلها، ثم قلبت الياء واوا، فثناذ لا يعَّرج عليه. بل ينبغي أن يعوَّل على باب "مبيع" و"مكيل" لأنه مطرد.

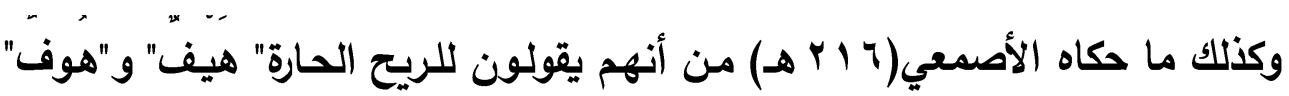
فلا حجة فيه لأبي الحسن في قوله "فُعل" من البيع :"بوع" فيقلب الياء واوا لاحتمـال أن يكونـا لفتين ، فيكون "هِّفِ" مـن ذوات اليـاء، و" هـوفَ" مـن ذوات الـواو نحو "التِّهـ" و "النُوهوه". 
ويحتمل أن يكون "الهيف" و" الهوف" معا من ذوات الواو، فيكون أصل "هيف":

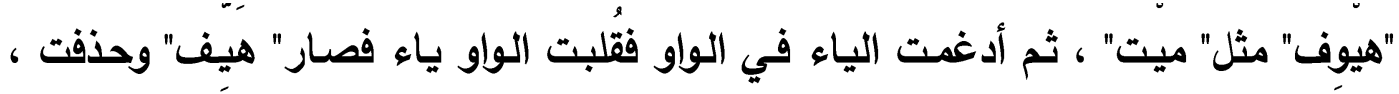

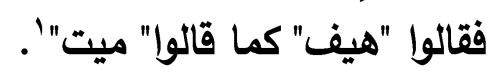

ويمكن القول إن ابن عصفور ذكر الخلاف بين سيبويه والأخفش في "الفُعل" مفردا

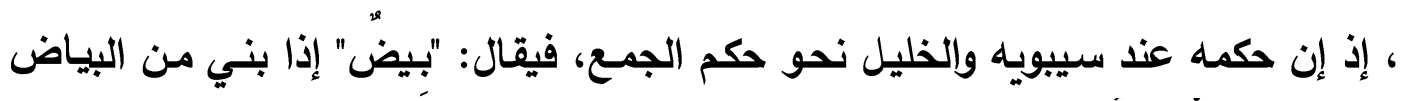

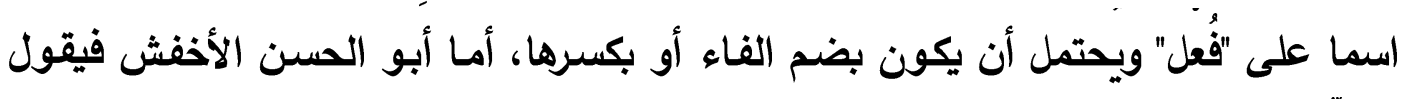

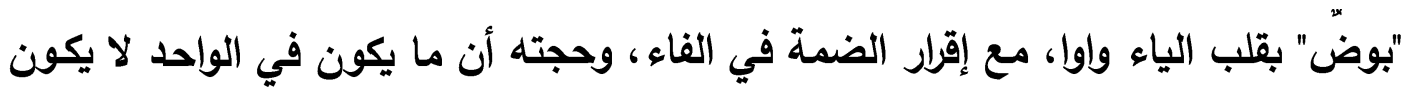

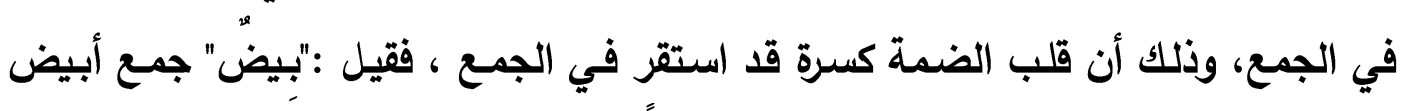

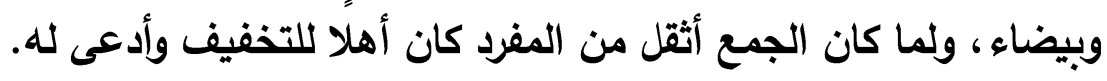

إن قلب الضمة كسرة إنما استقر في الجمع نحو :بيض في جمع أبيض، ولم يستقر

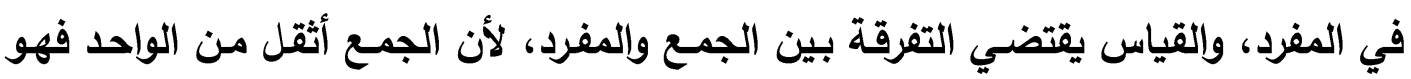

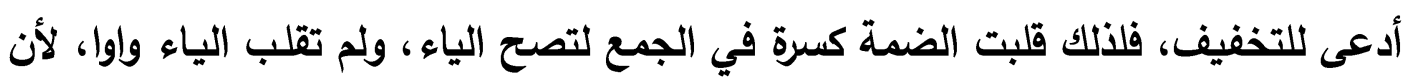

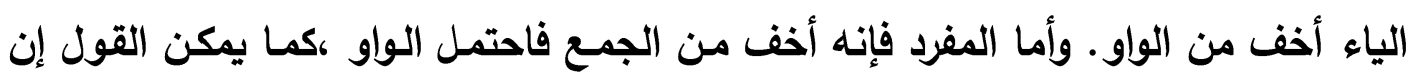
التخفيف عند بني تميم بإسكان العين.

\section{خامسنا ؛ التخفيف بالفتع}

(فُعلَ) بضم الأول وفتح الثالث- ليس من أبنية الاسم الرباعي المجردَّ(تفريع فُعَلَ على فُعُل)

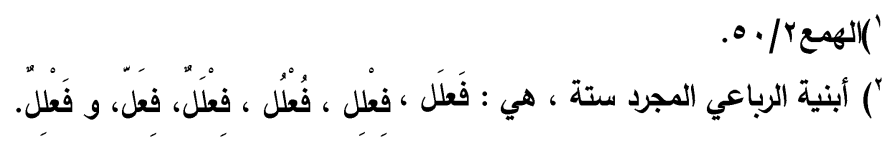

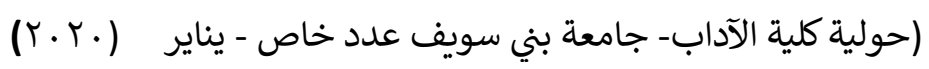




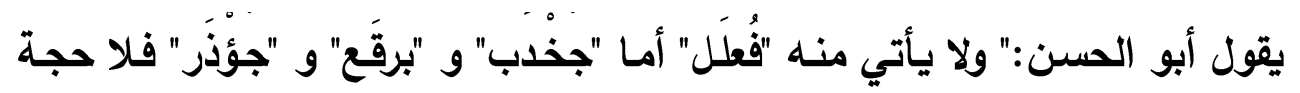

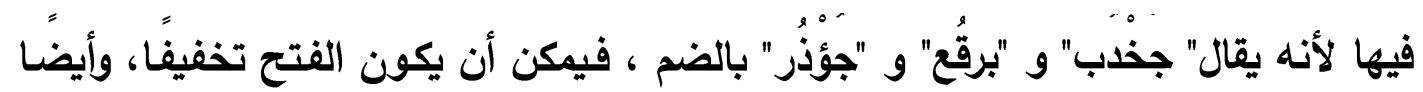

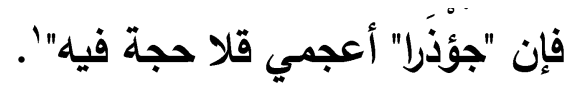

ويمكن القول: مذهب البصريين غير الأخفش أن هذا البناء ليس ببناء أصلي، بل

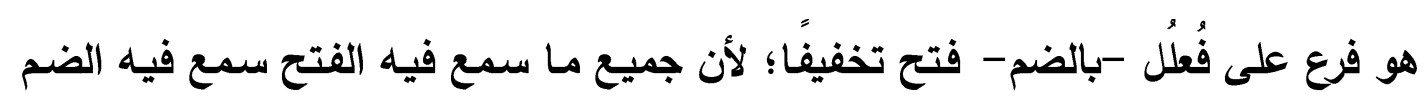
نحو جذب وطحلب وبرقع في الأسماء، وجرشع في الصفات، ويقال للمخلب :برثن، ولثجر

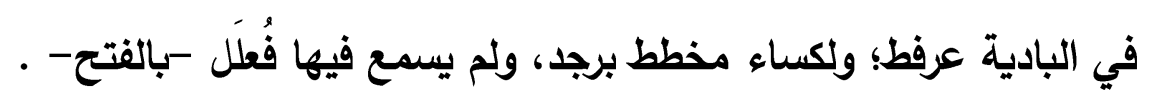
وذهب الكوفيون والأخفش إلى أنه بناء أصلي واستدلوا لذلك بأمرين:أحدهما :أن الأخفش قال: جؤذر، ولم يحك فيه ضم الذال، فدل على أنه غير مخفف، وهذا مردود، فإن

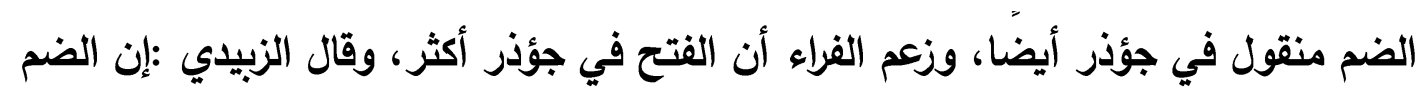

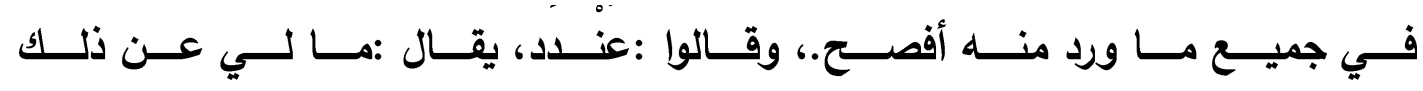
عند،، أي :بد، وقالوا :عاطت الناقة عوطَطا إذا اشتهت الفحل، وقالوا :سودد. فجاءوا بهذه الأمثلة مفكوكة'، وليست من الأمثلة التي استثنى فيها فك المثلين لغير الإلحاق، فوجب أن يكون للإلحاق. 


\section{سادسنا : التخفيف بالحذف}

الحذف أحد صور العدول عن الأصل ، ومـن قواعد الصرفيين: أنه لا حذف إلا بدليل، حيث يقوم هذا الدليل بالإثعار بأن ثمة محذوفًا. و المدذوف هنا يثعر بالأصل لأنه وفق ما يوجبه القياس.

وعلل ابن عصفور التخفيف بالحذف في المسائل التالية:

\section{1 - حلف واو "مفعول" من معتل العين}

ذكر أبو الحسن أن من المواضع التي تُنقل فيها حركة الواو والياء إلى السـاكن الصحيح قبلهما أن تكون كل من الواو أو الياء عينًا لاسم مفعول آت على( مفعول) :" وأما

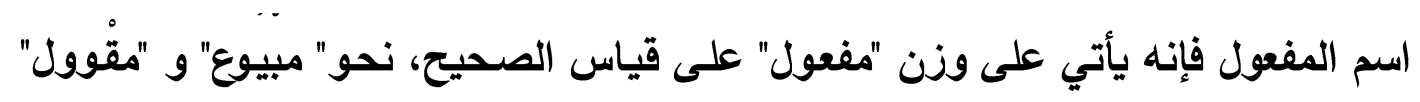

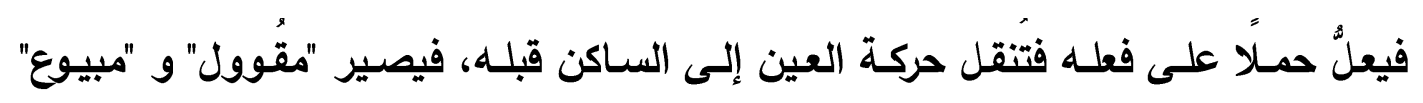
فيجتمع ساكنان: واو "مفعول" والعين، فتحذف واو "مفعول" فيقال" مقُول" في ذوات الواو. وأما "مبيوع" فإِنه إذا حذفت واو "مفعول" قُلبت الضمة التي قبل العين كسرة لتصحّ الياء فتقول" مبيع" ـ هذا مذهب الخليل وسيبويه' "'.وأما أبو الحسن "فإنه ينقل الحركة من

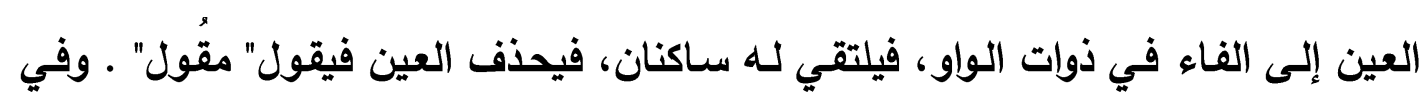
ذوات الياء نحو "مبيوع" ينقل الضمة من الياء إلى ما قبلها ، ثم يقلب الضمة كسرة لتصحّح

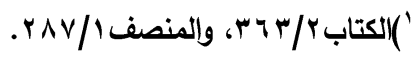

$$
\begin{aligned}
& \text { (r) }
\end{aligned}
$$

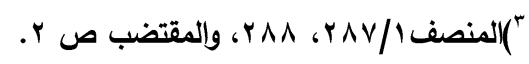

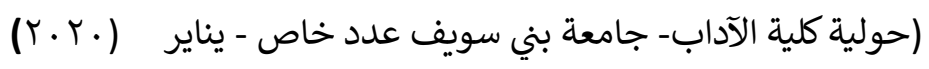


الياء، فيلتقي سـاكنان الياء وواو "مفعول"، فنحذف الياء، فتجيء الواو سـاكنة بعد كسرة، فتقلب الواو ياء فيقول "مبيع"'

فممـا يحتَجٌْ بـه للخليل أن السـاكنين إذا اجتمعا في كلمـة حرِكِ الثاني منهمـا دون الأول ، فكما يوصل إلى إزالة التقائهما بتحريك الثاني منهما كذلك يوصل إلى إزالة التقائهما بحذف الثاني منهما. وأيضًا فإن حذف الزائد أسهل من حذف الأصل، فلذلك كان حذف واو مفعول أسهل من حذف العين “ّولا يحفظ قلب واو "مفعول" ياء إلا أن يدغم نحو "مرمي" ،وأيضًا فإن واو "مفعول" أقرب إلى الطرف فحذفها أسهل.؛

$$
\text { وبمكن القول: }
$$

- أجزي الإعلال في الأجوف اليائي : مبيع بأن نقلت ضمة الياء إلى السـاكن الصحيح قبلها، إعلال بالنقل، فحذفت واو مفعول لالتقاء الساكنين: إعلال بالحذف، فقلبت الضمة كسرة لتصح الياء : إعلال بالقلب، وإنما قلبت الضمة كسرة لأن الياء والكسرة أخف عليهم من الواو والضمة .ومثل مفعول من الأجوف الواوي: مقول، أجري الإعلال مجرى مـا كان في اليائي ، فأسكنوا الواو الأولى كما أسكنوا في يفُعل و فَعل، وحذفت واو مفعول لأنهـ

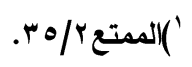

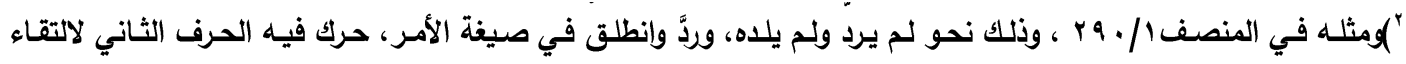

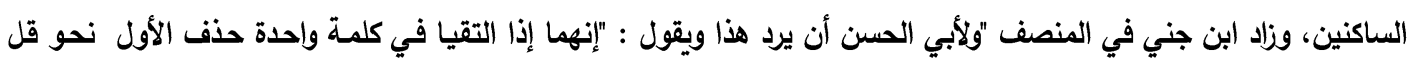

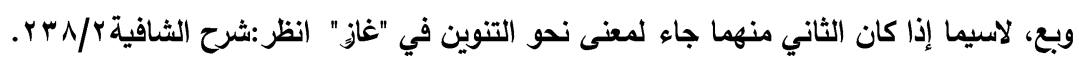

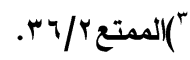
rv/r السنابق 


\section{د. حسن رمادي غانم نصر}

لا يلتقي سداكنان. وهنا إعلال بالنقل وبالحذف وبالقلب، ولذا يكون وزن نحو مبيع: مفعل بكسر الفاء وسكون العين ، ونحو مقول: مفعل بضم الفاء وسكون العين. ،ويرى الخليل

وسيبويـه أن المحذوف واو مفعول' .

r- تفسير ذلك : مقوول ـ ـ مقول مبيوع ـ مبيع بأنه: وقعت كل من

الواو والياء بوصفهما نصفي حركة في بدايـة مقطع متلوة بحركة طويلة (الضمة الطويلة) وفيـه ثقل، فعمد الناطق إلى إسـاط نصف الحركة ، وبأسقاطهما يتكون مقطع لا تجيزه العربية، فنقل الصامت السـابق عليه إلى بداية المقطع الثاني ليكزن مـع الحركة الطوبلـة مقطعا مقبولًا، ول لتفريق بين الأصل الواوي واليائي نقلت الضمة الطويلـة في اليائي إلى كسرة طويلة . ب- ندر إثبات واو" مفعول "فيمـا عينه واو فقالوا" ثوب مصوون ومسكك مدووف

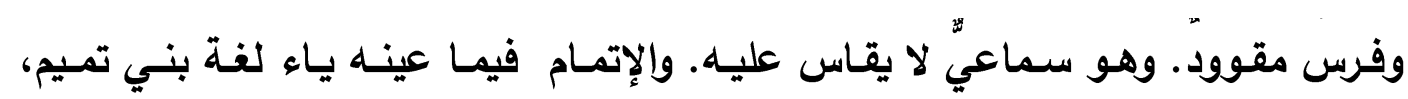

'ايقويهه ما ذكره أبو علي -قول الثاعر: سيكفيك صرب القوم لحم معرض ... وماء قدور في القصاع مشيب ماتول

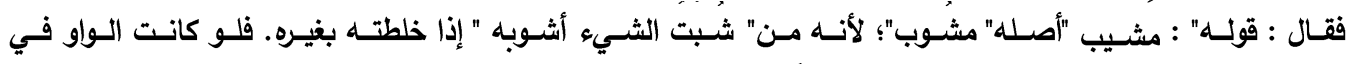

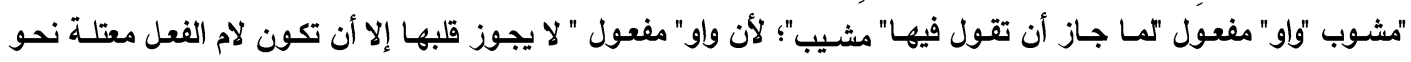

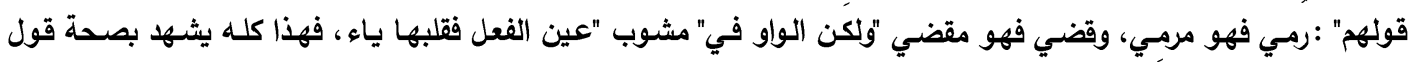

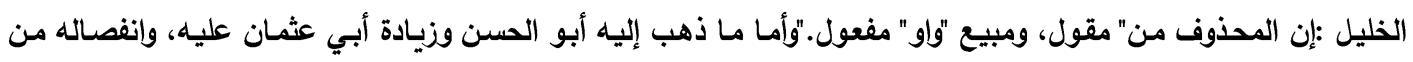

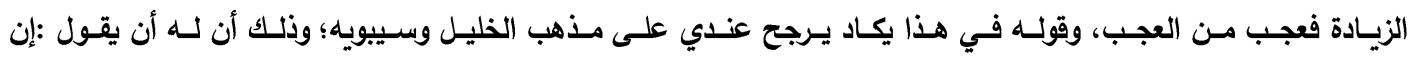
واو" مفعول " جاءت لمعنى وهو المد، وإلعين لم تأت لمعنى، فحنف العين التي لم تأت لمعنى، وتبقية ما جاء لمعنى وهو الواو

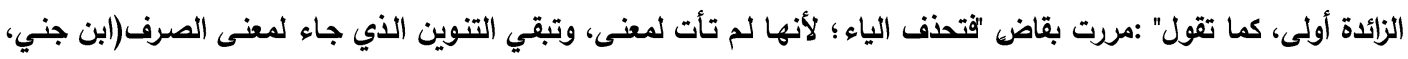

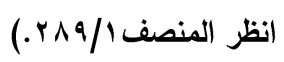

(حولية كلية الآداب- جامعة بني سويف عدد خاص - يناير (·. ) 
فيقولكون مخيوط ومبيوع. " فالأفصح في اسم المفعول من الثلاثـي الأجوف اليائي هو الإعلال، فيقال في "باع" "مبيع" ، ويجيز بعض العرب الإتمام فيقولون "مبيوع".

\section{r - مدف خاء الثهال الواوي في المشارع}

تحذف فاء المثال الواوي في المضارع، يقول أبو الحسن: "علة حذف الواو في

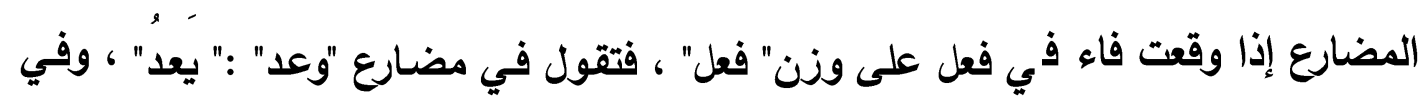

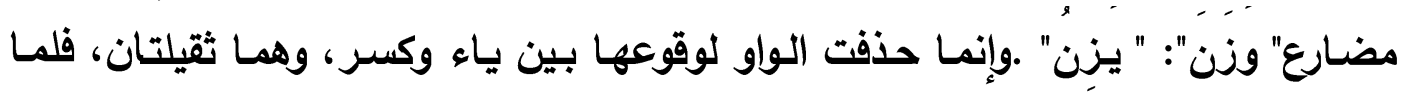

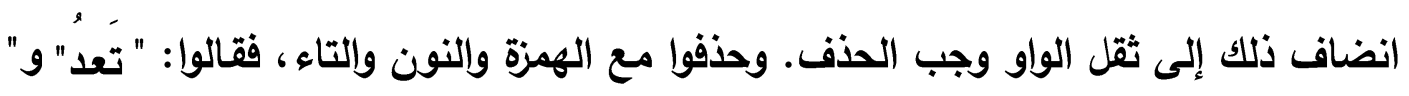
أَعد" و" نَدُ" حملًا على الياء.

وذكر أبو الحسن أن الإعلال بالحذف في مضارع الفعل المزيد بالهمزة الذي على وزن أفعل فتحذف الهمزة الثانية ، و يقع بأن تحذف الواو إذا كان فاء في فعل على وزن

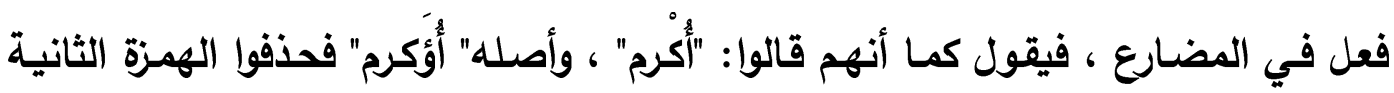

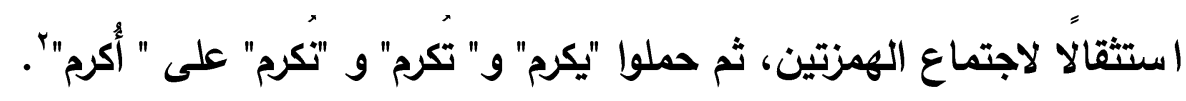

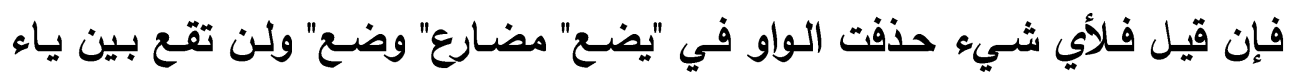
وكسرة، فالجواب أنها في الأصل وقعت بين ياء وكسرة لأن الأصل "يوضع" ، لكن فتحت 


\section{د. حسن رمادي غانم نصر}

العين لأجل حرف الحلق، ولولا ذلك لم يجئ مضارع "فَعل" على" يفْعل" بفتح العين. فلما كان الفتح عارضًا لم يعتد به، وحذقت الواو رعيا للأصل.'

ويمكن القول إنه متى كانت الواو فاء الفعل وماضيه على" فَعل"، أو"قَعل "ومضارعه "،

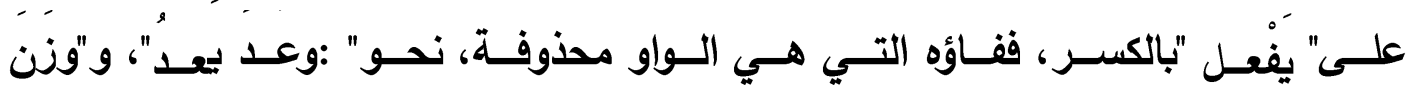

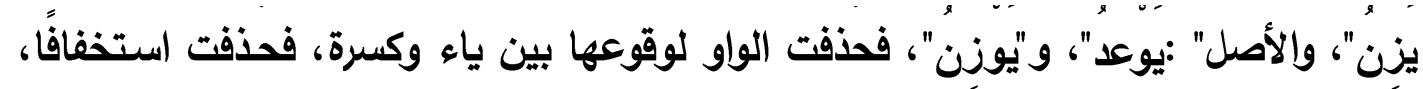

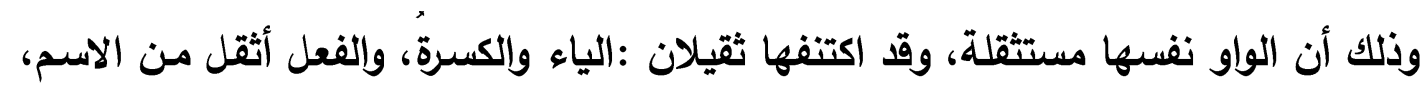
ومـا يعرضِ فيه أثقل ممـا يعرض في الاسم، فلمـا اجتمعِ هذا الثقل آثروا تخفيفه بحذف شيء منه، ولم يجز حذف الياء لأنّه حرف المضارعة، وحذفه إخلال مع كراهية الابتداء بالواو، ولم يجز حذف الكسرة لأنّه بها يعرف وزن الكلمة، فلم يبق إلا الواو، فحذفت. وكان حذفها أبلغ في التخفيف لكونها أثقل من الياء والكسرة مع أنها ساكنة ضعيفة، فقوي سبب

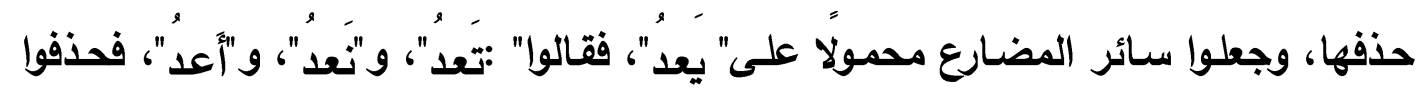

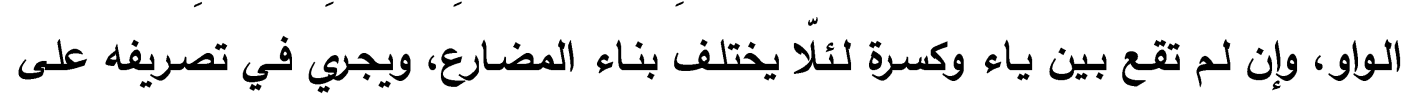
طريقة واحدة مع ما في الحذف من التخفيف.

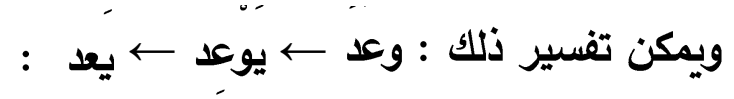

إن الواو بوصفها حركة ضعيفة وقعت في نهاية مقطع متوسط مغلق(ص ح ص) ساكنة، وقد ضعفت في ذاتها وموقعها وسكونها، مما أدى إلى حذفها من صيغة 
المضارع، فتحول المقطع المتوسط المغلق إلى مقطع قصير(ص ح)

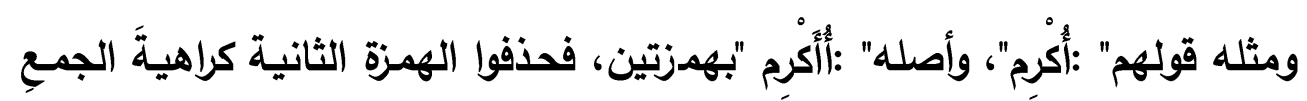

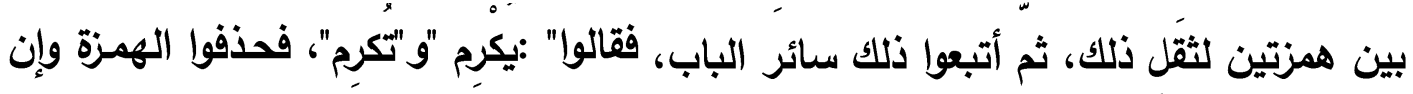
لم توجَد العلّة، فيجري الباب على سنَن واحد' ..فذهاب الهمزة هنا نظير ذهابها من أمثلـة

$$
\begin{aligned}
& \text { مضارع "وعد" ونحوه. }
\end{aligned}
$$

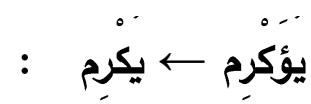

استثقل النطق بالهمزة الواقعة في بايـة مقطع متوسط مغلق(ص ح ص) الأمـر

$$
\text { الأي أدى إلى حذف الهمزة والحركة القصيرة اللاحقة بها ـ }
$$

ويتفرع من حذف فاء المثال الواوي في المضارع مسألتان:

الأولىى: عدم حذف الواو عندما تقع فَاء "فعل ومضارعه يَفْلَ"

يقول أبو الحسن: "وإن وقعت الواو فاء في فعل على وزن "فَعلَ" بكسر العين فِانِ مضارعه يجيء على قياسه من الصحيح وهو "يفُعل" ـ ولا تحذف الواو لأنها لـم تقع بين

ياء وكسرة نحو" وجل يوجل"

فإن قيل: فلأي شيء لم يجيئوا بمضارعه على" يفْلَ" بكسر العين فيكون ذلك سببًا

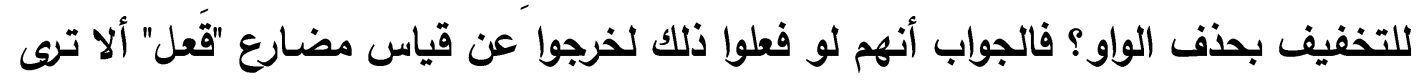




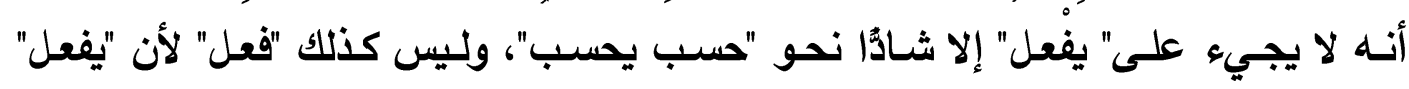

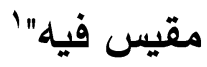

ويمكن القول: في مضارع فعل يفعل مثل وجل يوجل "أربع لغات :وجل يوجل بإثبات

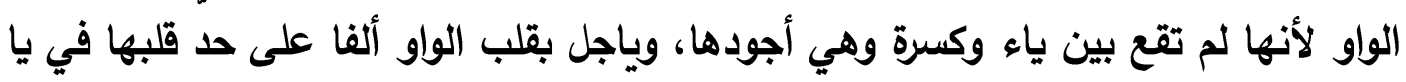

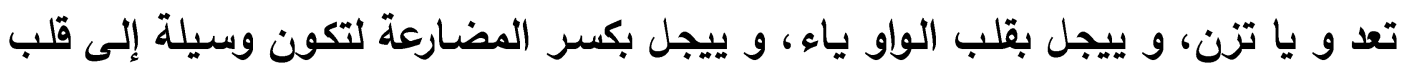

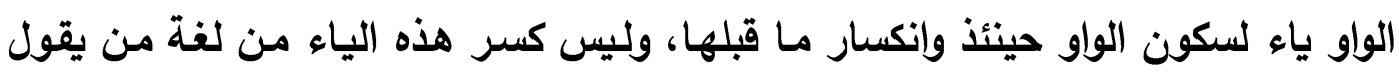

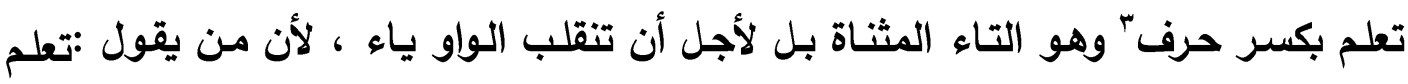
بكسر التاء الفوقية لا يقول يعلم بكسر الياء التحتية فهي لغة أخرى. الثانية: عدم حذف الواو من مضارع فعل على وزن" فعل"

تحذف الواو إذا كانت فاء لفعل مفتوح العين في الماضي مكسورها في المضارع،

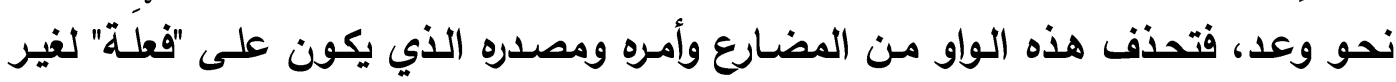

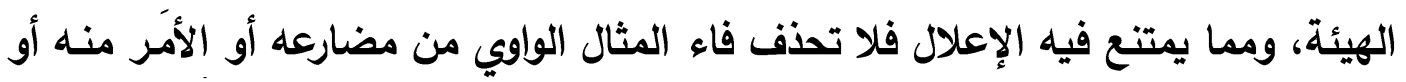

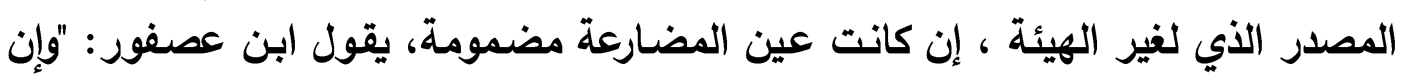

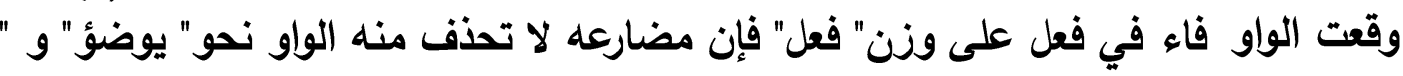

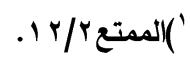

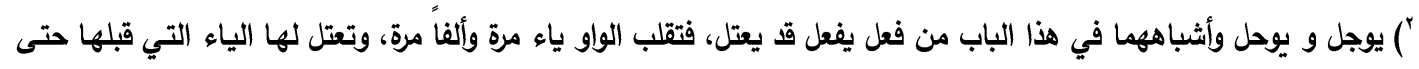

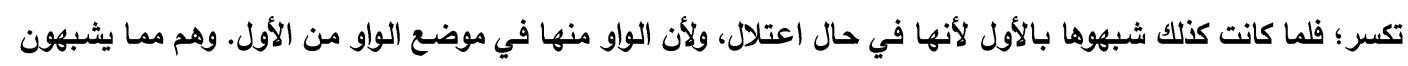

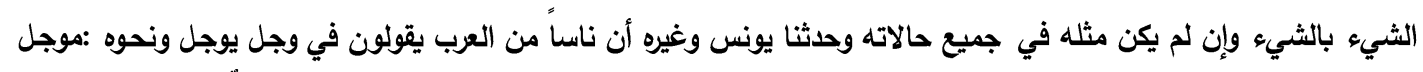

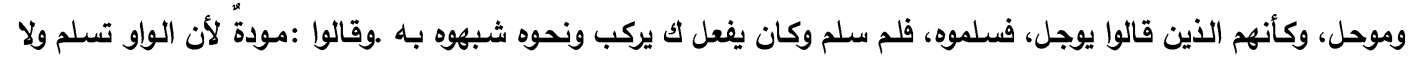

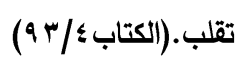

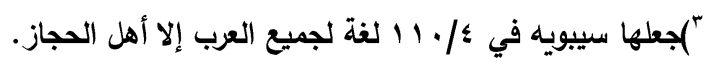

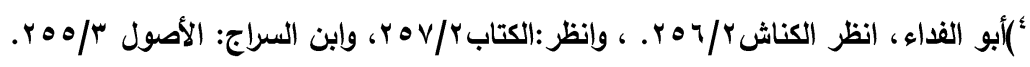

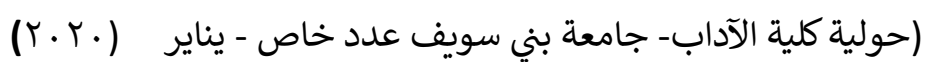


يوطؤ" لما ذكرنا من أن الواو بين الياء والضمة أخف منها بين الياء والكسرة."' ويمكن القول :

1 - لما كان مضارع(فَعل) لا يكون إلا على(يفْل) لم تحذف فاؤه للتفريق بين أبواب المضارع دفعا للبس.

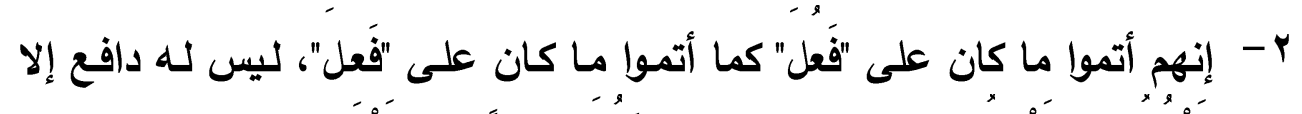

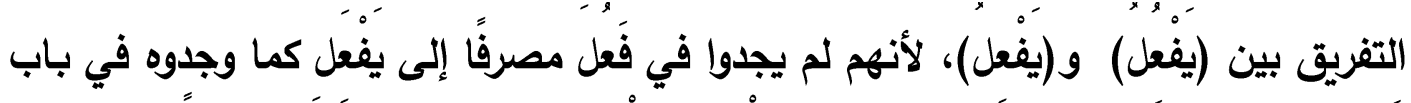

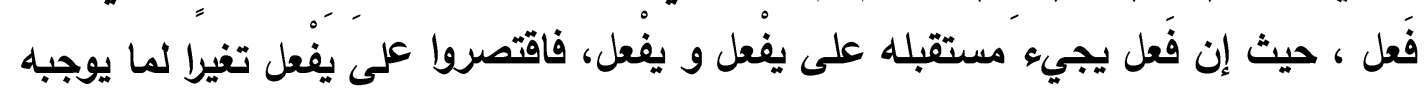

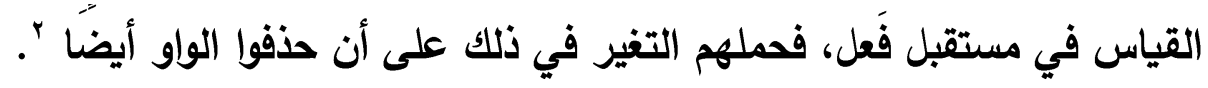

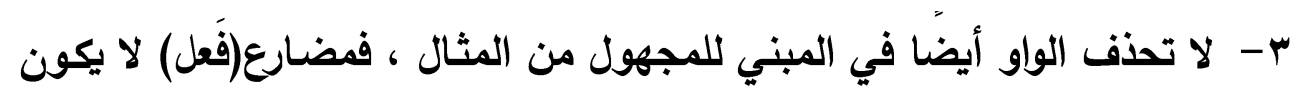

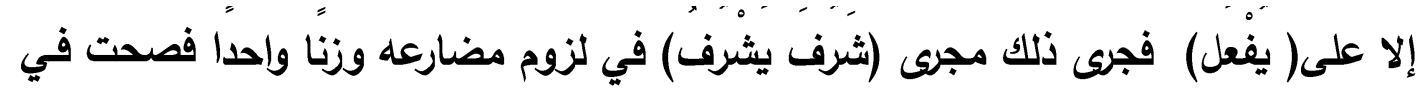

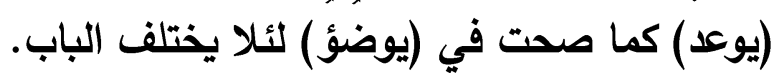

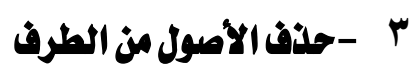

يقول أبو الحسن: "فإن قيل: فقد وجدناهم حذفوا الاصل وأبقوا الزيادة لمـا كانت لمعنى، فقالوا "تقَّى" في "اتَقىى" فحذفوا التاء الاصلية وابقوا تاء "|فتعل" .فالجواب أن الذي

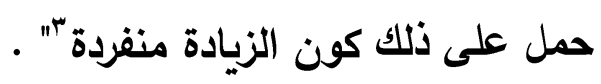

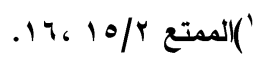

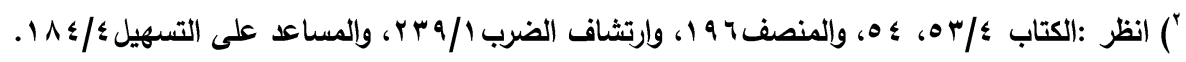

$$
\begin{aligned}
& \text { (1) }
\end{aligned}
$$




\section{د. حسن رمادي غانم نصر}

ويمكن القول إنك إذا نقلت الضمة من العين إلى الفاء في "مفعول" من ذوات العين اجتمـع لك سـاكنان: واو "مفعول" والياء ، فتحذف واو "مفعول" فتجيء الياء السـاكنة بعد

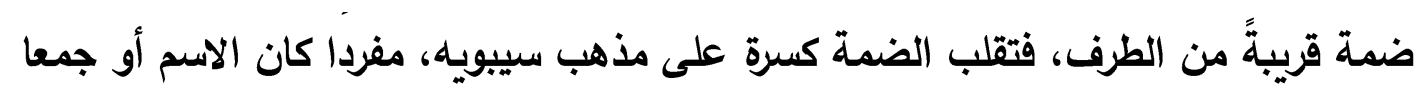

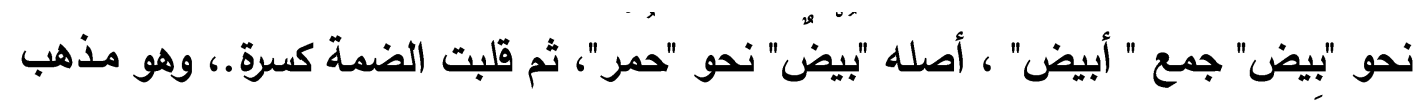
سيبويه واستحسنه ابن عصفور.

وأمـا أبو الحسن الأخفش فيلزمسه على مذهبه أن يقول "مبوع" وذلك أن الأصسل

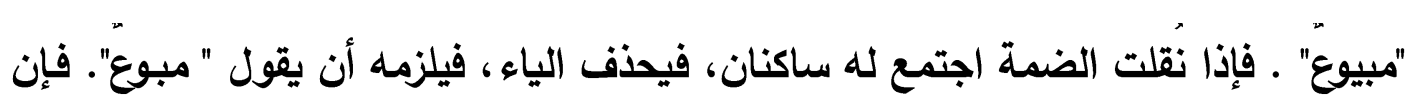
قال : لا أحذف إلا بعد قلب الضمة كسرة. فالجواب أن يقال له : لم تقلب الضمة كسرة وأنت تزعم أن الياء إذا جاءت ساكنة بعد ضمة في مفرد فإن الياء هي التي تقلب واوا بشرط

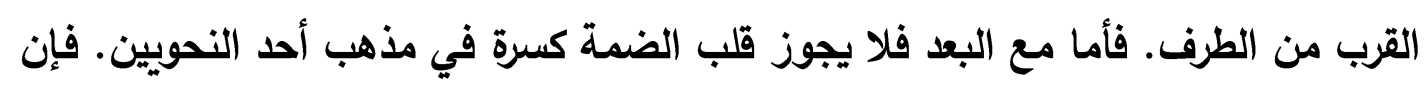

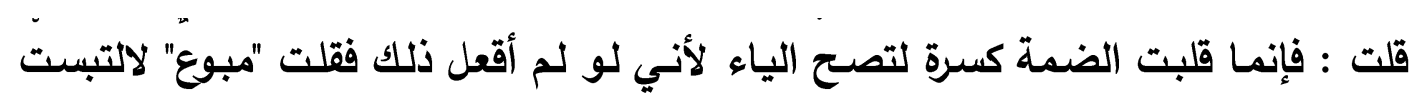
ذوات الياء بذوات الواو. فالجواب أن هذا القدر لو كان لازمـا لوجب أن تقول "ميقن" في " موقِن" لئلا يلتبس بذوات الواو ـ فكما أن العرب لم تفعل ذلك في "موقِن" فكذلك لا تفعله في "مبيح" وأمثاله.

')(ميقن):قلبت الياء واوا إذا كانت ساكنة مفردة وقبلها ضمة وهي فاء في الاسم، وعلة القلب كراهية الياء الساكنة بعد الضمة، وهو نظير كراهية الواو الساكنة بعد الكسرة في "ميزان" و"قيل". وقعت الياء وهي نصف حركة- بعد ضمة قصيرة، ونصف الحركة

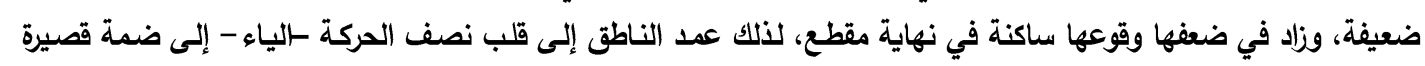

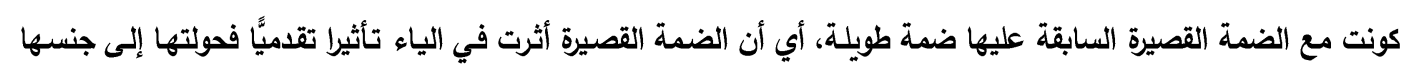
من أجل إحداث تجانس بين الصوتين المتجاورين. 


\section{ع - حاثض الأثف في الوخف}

يقول أبو الحسن: " حذفت الألفف في" أم والله لأفعلنَّ" يريـدون" أمـا والله". وربمـا

حذتت في الوقف تخفيفًا. قال لبيد' :

وقُبيل من لُكيز حاضر رهط مرجوم ورهط ابن المعلّ

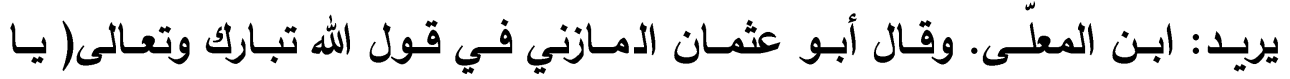

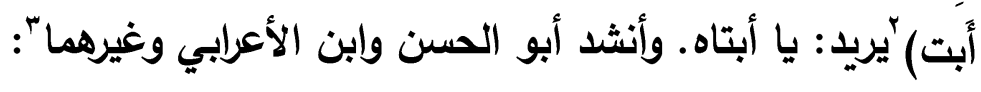

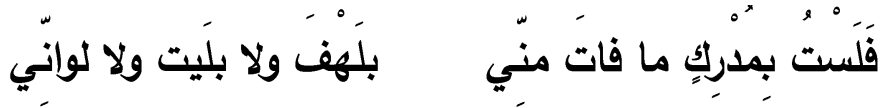

أراد "بلهفا" ثم حذفت الألف. وحذف الألف على الجملة قليل؛

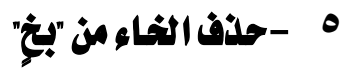

"بخْ" مخففة والأصل" بَّه" ، يقول أبو الحسن:" حذفت الخاء من "بخ" والأصل" بخّ" ،

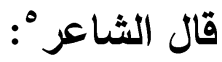

بَخْبخ لَوالده ولَلمولْود

بين الأثج وبين قيس باذخ

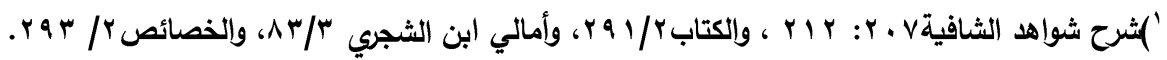

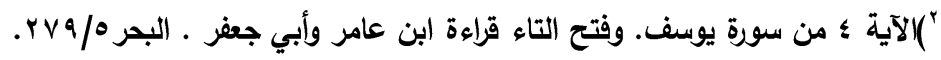

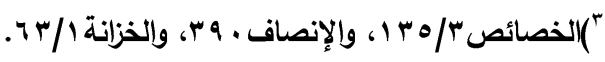

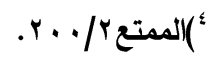
(أعشى همدان ،اللسان (بخبخ). 
ويدل على أن أصله التثقيل قول العجاج(0 ؛ اهـ)':

$$
\text { في حسبِ بِّ و عزّ أقعساَ }
$$

ويمكن القول أن حذف الخاء هنا ليس لأي علة تصريفية سوى التخفيف.

\section{7}

أفَ مخففة الفاء أصلها "أفَ" بتثقيل الفاء، يقول أبو الحسن:" قالوا في التضجر

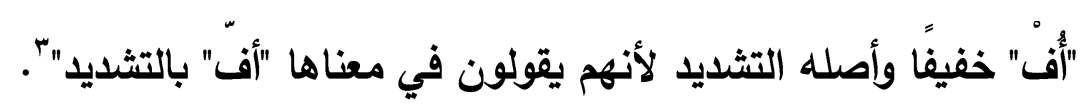

ويمكن القول إن "أفت" المخففة لغة في "أُف" طلبا للتخفيف لثقل التضعيف.

\section{- حذف الطاء من "قط" V}

"قَطْ" بتخفيف الطاء نحو "بخْ" ، وأصلها "قطّ" بالتضعيف، يقول أبو الحسن:

"حذفت الطاء من "قَطْ" لأنـه من قطقتَ" أي قطعت، لأن معنى قولك: " مـا فعلته قط" أي

فيما انقطع من عمري. فهذه جملة كافية عن المحذوف على غير قياسء".

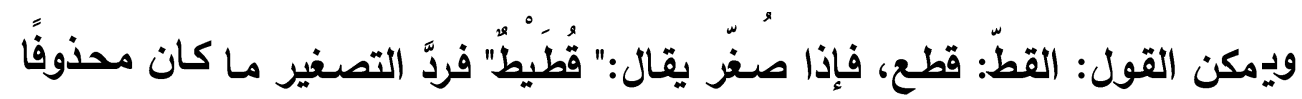

وهو الطاء. و "قطْ" مخففة بمعنى: حسب وغلب عليها التخفيف .

$$
\begin{aligned}
& \text { 'الكسان(بخبخ). } \\
& \text { r }
\end{aligned}
$$

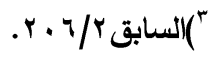

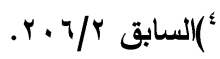




\section{سابعًاء التغثفيف بالثقل}

من صور التخلص من الاستثقال : التخفيف بالنقل.

وقد علل ابن عصفور التخفيف بالنقل في المسائل التالية:

$$
\text { نقل حركة العين إلى الفاء قبلها }
$$

عند إسناد الفعل الثلاثي معتل العين إلى ضمير متكلم

يعرض أبو الحسن لإعلال الفعل الأجوف المسند إلى ضمير المتكلم أو المخاطب، ويفوته ذكر نون الإناث الغائبات ، مع أنه مثلهما في الحكم، حيق يقول :"فإن أسند الفعل

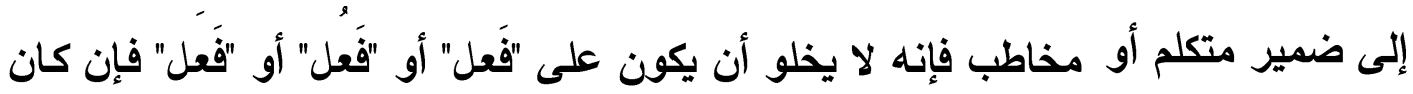

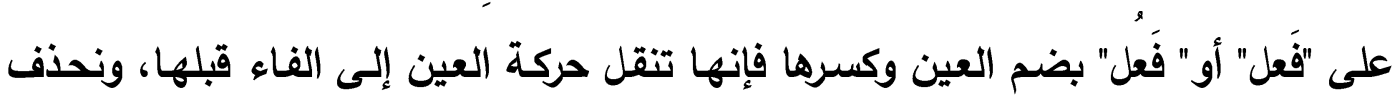

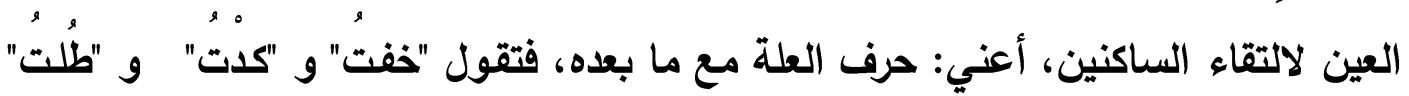
فتكسر الفاء من "فَعل" ، وتضم الفاء من" فَفُل "فُإن قيل: فلأي شيء لما حذقوا العين نقلوا حركتها إلى الفاء؟ فالجواب أنهم لمـا اضطروا إلى الحذف كان الأسهرل عندهم ألا يحذفوا الحرف بحركته، وأن يبقوا الحركة التي كانت في العين فنقلوها إلى الفاء لذلك. وأيضًا فإنهم أرادوا أن يفرقوا بين حذف عين الفعل المتصرف وغير المتصرف، فلما كانوا لا ينقلون في غير المتصرف ،فلما كانوا لا ينقلون في غير المتصرف فيقولون "لست" في" ليس" نقلوا في 


\section{د. حسن رمادي غانم نصر}

المتصرف. فإن قيل: ليست عين "ليس" متحركة، فلم يكن فيها مـا ينقل ، فالجواب أن

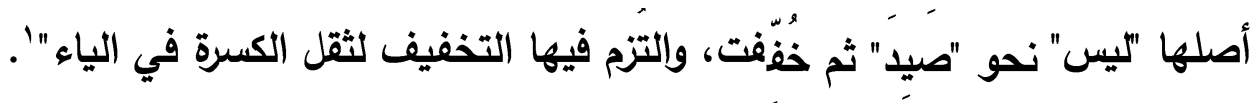
ويمكن القول إن أبا الحسن في معرض حديثه عن الإعلال ' في الفعل: مضارع

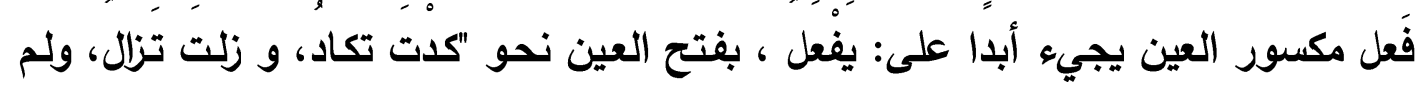

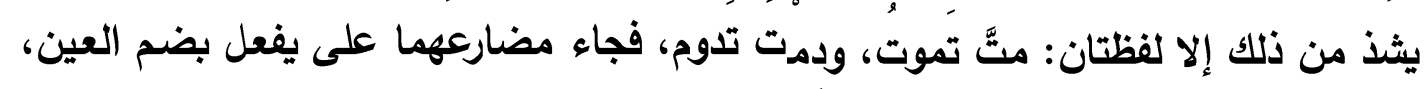
على أنه يمكن أن يكون من تداخل اللغات . لع.

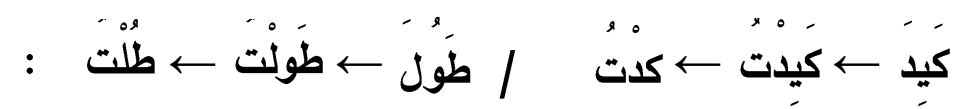

وقعت الياء والكواو بوصفهما نصفي حركـة في بدايـة مقطع ومحركـة بحركة من جنسها، وفي ذلك كراهية فأسقطتا وأسقطت الفتحة السابقة عليها ، فتفير التثكيل المقطعي للبنية فأصبح يتكون من مقطعين بدلاً من ثلاثة مقاطع، ولم تحذف الكسرة ولا الضمة لتدل على الأصل اليائي والواوي.

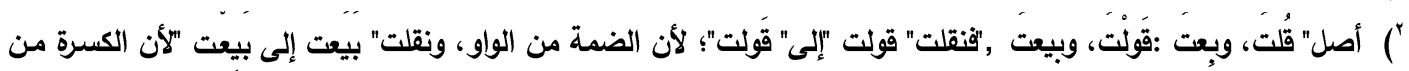

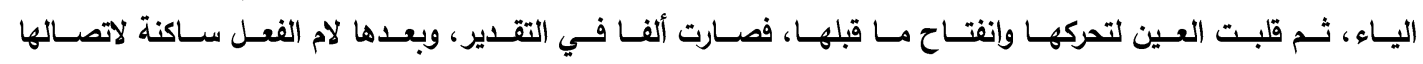

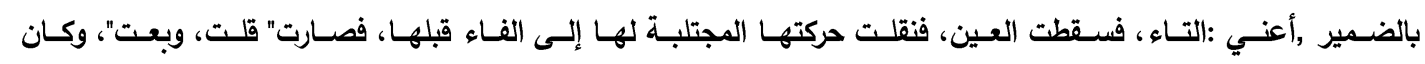

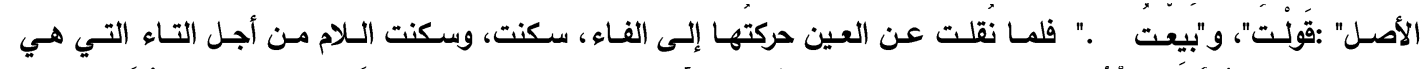

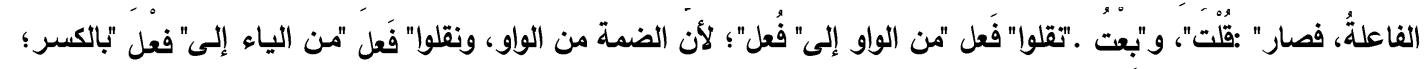

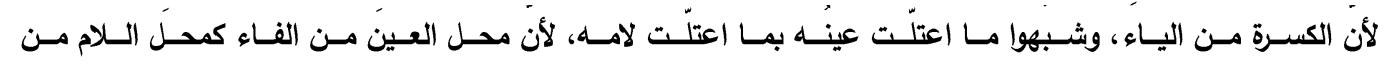

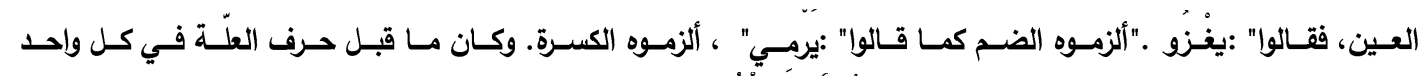

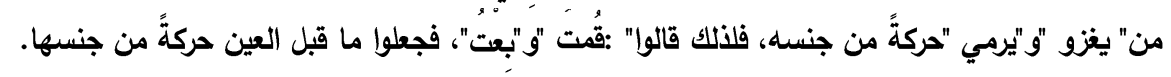


وبعض العرب لا يبالي الالتباس، فيقول" :وقد كيدَ زيدّ يفعل كذا وكذا"، و"مـا زِيل

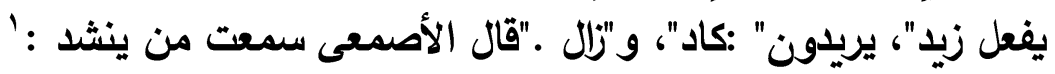

وكِيا ضباع القف يأكلن جثتي وكيد خراش بعد ذلك ييتم

ويمكن القول: " كاد"، فيها مذهبان للعرب : قوم يجعلونها من الواو، وقوم من

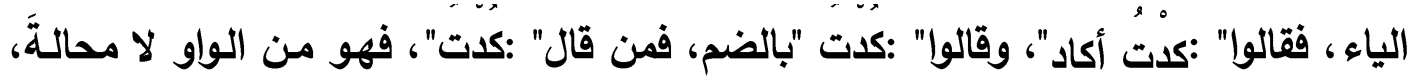

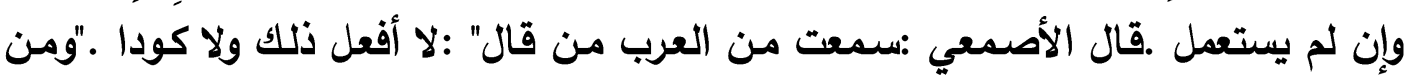

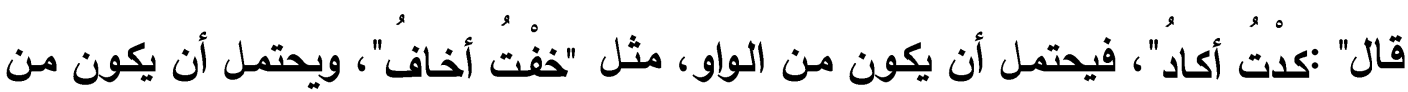

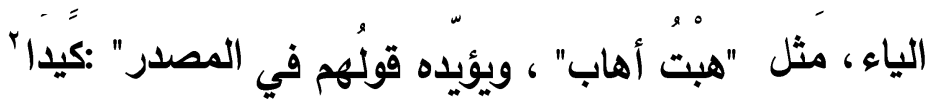

\section{ثُامنًا ؛ التخفيف بالسكون}

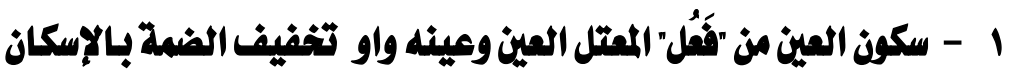

يقول أبو الحسن: "فإن كان على "فُعل" من الواو فإنه يخالف الصحيح في لهن

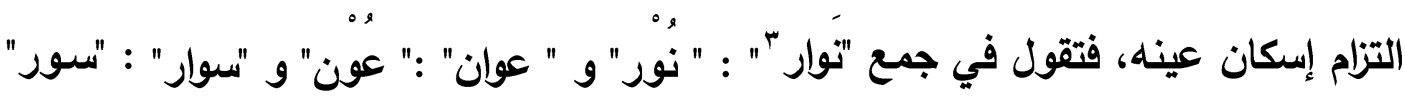
بالإسكان ليس إلا. وذلك أنه لما انضاف إلى ثقل الضمة ثقل الواو لم يجز إلا السكون لأنده

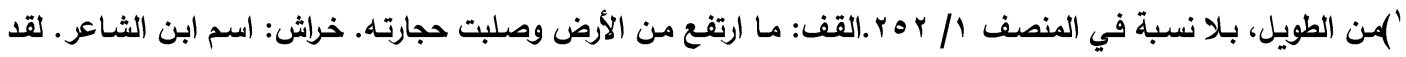
أوشكت ضباع هذه الأرض المرتفعة أن تأكلني، وبالتالي كان ابني -لو فعلت- قد صار يتيما. المضارع" :يكاد "و "يزال"، فنقلوا

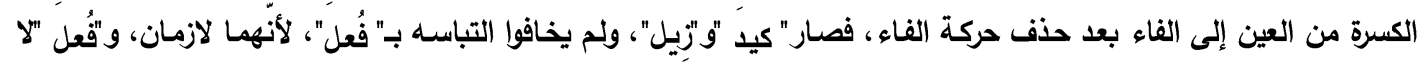

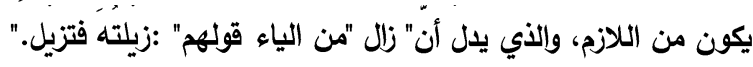

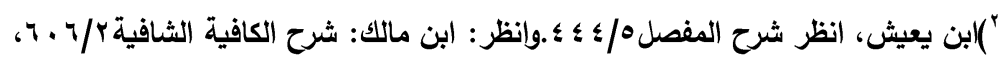
جاء جاء في لِسان العرب: النَّوار: المصدر، وإلنّوار: الاسم ومن ثم لا يجب فيها الإعلال ،فالإعلال يتحقق في المصدر لا في

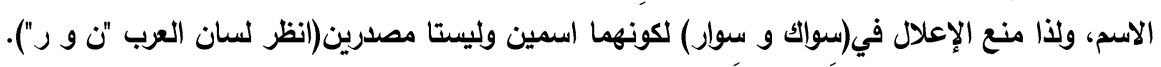


كلمـا كثر الثقـل كـان أدعى للتخفيف. وليس كذلك في الصـيح بـل يجوز فيـه التحريك

$$
\text { والإسكان نحو "رسل" و "رسل" }
$$

ولا يجوز تحريك العين من "فُعل" المعتل العين إلا في ضرورة، نحو قوله' :

$$
\begin{aligned}
& \text { مِن مبرقِاتِ بالبرِينِ وتَبَدو }
\end{aligned}
$$

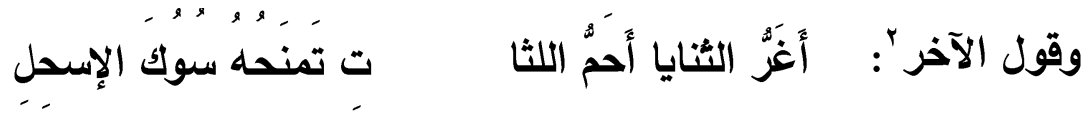

وليس الأمر كذلك في "فُعل" الذي عينه ياء بل يجوز فيه التحريك والتسكين نحو"

$$
\text { عيان" و "عين" ، وقالوا: "بيوض " و بيض"ه }
$$

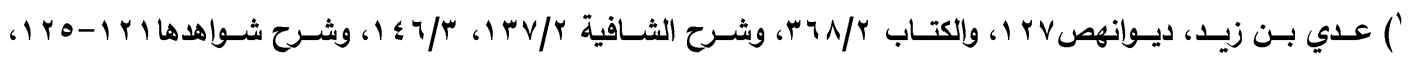

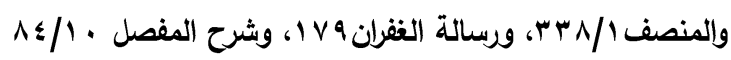

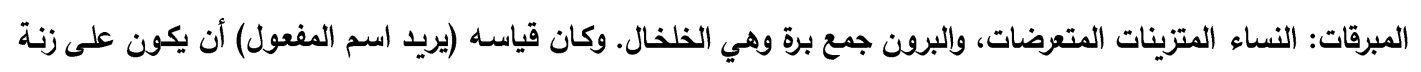

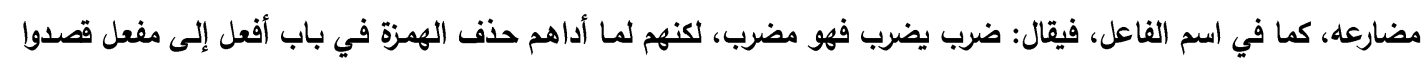
تغيير أحدهما للفرق، فغيروا الثلاثي لما ثبت التغيير في أخيه، وهو اسم الفاعل، لأنه وإن كان في مطلق الحركات والسكنات

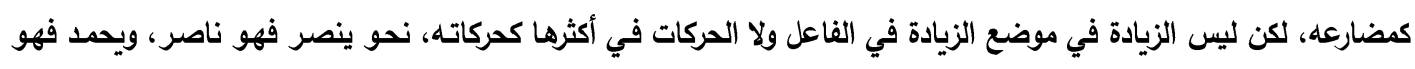
حامد، وأما اسم الفاعل من أفعل فهو كمضارعه في موضع الزيادة وفى عين الحركات فغيروه بزيادة الواو، ففتحوا الميم لئلا يتوالى ضمتان بعدها واو، وهو مستثقل قليلا كمغرود وملمول وعصفور، فبقى اسم المفعول من الثلاثي بعد التغيير المذكور

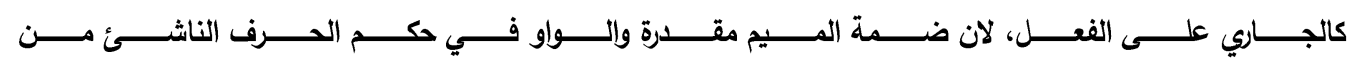
الإثباع كقوله: " أدنو فأنطو ر " اه وقوله " أدنو فأنظور " قطعة من بيت هو: وأنني حيثما يثنى الهوى بصرى * من حيث ما سلكوا أدنوا فأنظور

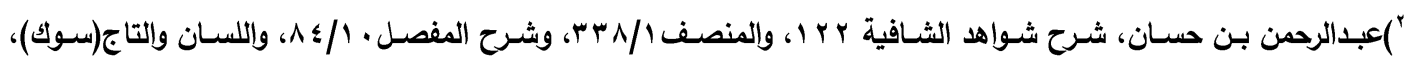

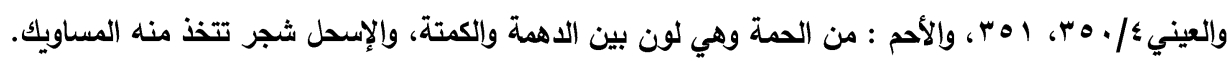
(بالعيان: حديدة في متاع الفدان. ؛) (البيوض: الاجاجة الكثيرة البيض.

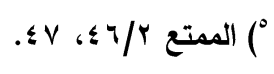

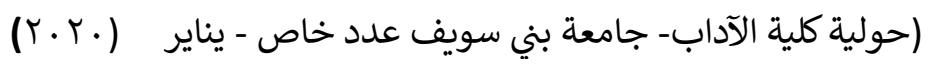




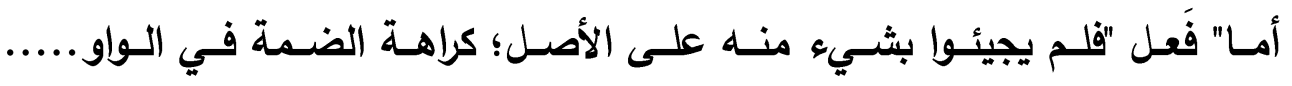
وكذلك" نُور، جمع نَوار "لما وجدوا لها مثالا من الصحيح يسكن أسكنوها نحو" رسل فإذا كانوا يسكنون في" رسل "مـع أن الضمة لا تستثقل في السين كما تستثقل في الواو، فهم بتسكين الواو في" نُور "وترك الضم أجدر، ولو وجدوا سبيلًا في" أدؤر، ونور "إلى قلب الواو ألفاً فعلوا ذلك، ولكنهم لم يجدوا فغيروا بالهمز والإسكان، وإذاوجدوا سبيلاً إلى قلب الواو ألفًا في" فُعل "من" قام"قلبوا فقالوا" قام هذ هو القياس '" ويمكن القول إنه يجب في غير الضرورة تسكين عينه إن كانت واوا وجب تسكينها، ولا يجوز بقاؤها على الحركة إلاّ في الضرورة، وإن كانت ياء جاز البقاء على الدركة وجاز التسكين، لكن إذا سكنت الياء وجب كسر الفاء، وإن كانت حرفًا صحيحا جاز فيه التسكين ،كما يجوز تسكين ما كان على فعل الذي هو مفرد، نحو :عنق في عنق إلّا أن تكون العين مضاعفة فيجب البقاء على الحركة، ولا تسكن إلّا في الضرورة، فمثال التسكين في الواو قولثهم : نور جمع نوار، وعون جمع عوان، وسور جمـع سوار، وسوك جمع سواك، وخون

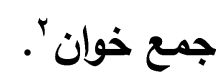

حذفت الضمة في نُور جمع نَوار استثقالًا للضمة على الواو، فأعل بالنقل :في نحو أبيناء خاصـة مـع عدم الموازنـة المذكورة، لثدة الاستثقال، وعدم الإعلال في نحو أبيناء 


\section{د. حسن رمادي غانم نصر}

أكثر، بل النقل شـاذ، بخلاف نحو نُور في جمع نَوار فإن الإسكان فيه أكثر لكون الواو

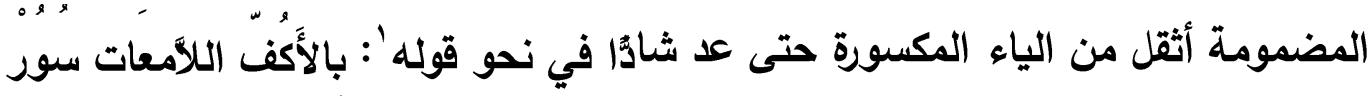

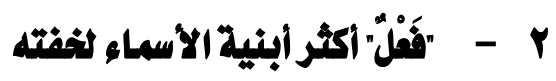

ذهب أبو الحسن إلى أن فَعْل" أكثر أبنية الأسماء لذفته : " ألا ترى أن "فَّمَلا" على

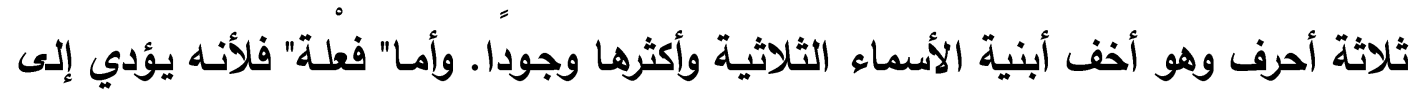
حذف الواو وهو حرف مستثقل.كما أنهر التزموا في المضارع "يفْعل" بكسر العين لأنه يؤدي لحي إلى التخفيف، ولو جاء على غير ذلك من الأوزان التي يجيء عليها مصدر الفعل الثلاثي الصحيح لم يكن في خفة ذلك"ז.

\section{تاسعًا التخفيف بوجوب الإدفام}

\section{وجوب التزام لام التعريف بالإدغام}

يقول أبو الحسن في اجتماع ثلاثة موجبات للتخفيف: "أمسا اللام فإنها تدغم في

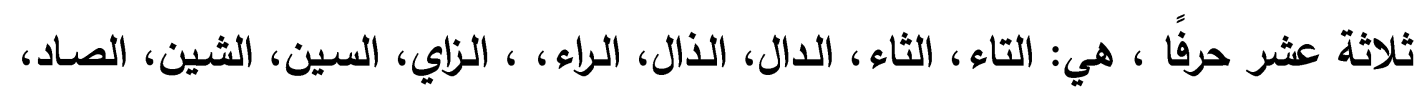
الضاد، الطاء، الظاء، والنون.

وإنما أدغمت في هذه الحروف لموافقتها لها، وذلك أن التلام من طرف اللسان ،

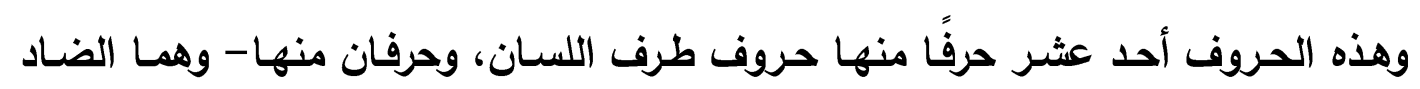

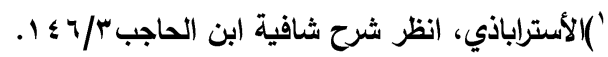

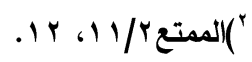

(حولية كلية الآداب- جامعة بني سويف عدد خاص - يناير (·. ) 
والسين-يخالطان طرف اللسان، وذلك أن الضـاد لاستطالتها اتصلت بمخرج التلام، وكذلك الثين بالتفثي الذي فيها لحقت أيضا مخرجها.

فإن كانت اللام للتعريف التزم الإدغام ولم يجز البيان، والسبب في ذلك أنـه انضـاف إلى ما ذكرناه من الموافقة كثرة لام المعرفة في الكلام؛ ألا ترى أن كل نكرة أردت تعريفها أدخلت عليها الـلام التي للتعريـف إلا القليل منها. وكثرة دور اللفظ في الكـلام تستدعي التخفيف. وأيضا فإن لام المعرفة قد تنزلت منزلـة الجزء مما تدخل عليه وعاقبها التنوين. واجتماع المتقاربين فيما هو كالكلمة الواحدة أثقل من اجتماعهما فيما ليس كذلك. فلما كان فيها ثلاث موجبات للتخفيف سوهي: ثقل اجتماع المتقاربات، وكثرة التكلم بها، وأنها مع ما بعدها كالكلمة الواحدة- التزم فيها الإدغام' . فهي أحد عشر حرفًا من حروف طرف اللسـان، وحرفـان يخالطان طرف اللسـان، وهما الضاد، والثين، وإنمـا أُدغمت لام التعربف في هذه الحروف لوجهين: أحدهما :أَنَّ هذه الحروف مقاربة لها.والثاني :أَنَّ هذه اللام كَثُ دورها في الكلام؛ ولذلك، تدخل في سائر الأسماء، سوى أسـماء الأعلام؛ والأسماء غير المتمكنة، ولَمَّـا اجتمـع فيها المقاربـة لهذه الحروف، وكثر ا دورها في الكلام؛ لزم فيها الإدغام، وأما من أظهر اللام على الأصل، فمن الثاذ الذي لا يعتد بهُ؟.

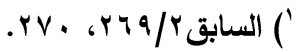

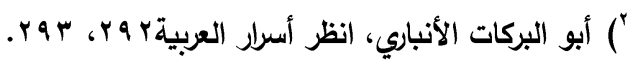




\section{د. حسن رمادي غانم نصر}

ويمكن القول إن ابن عصفور استند في وجوب إدغام لام التعريف إلى:

ا - موافقـة الـلام لهذه الأصـوات في المخرج ، فهي عنده يجمعها مخرج طرف اللسان باستثناء صوتي الضاد والثين، فهما يصـلان إلى مخرج طرف اللسـان بالاستطالة التي في الضاد وبالتفشي الأي في الثين. r - كثرة ورود لام التعريف في الكلام لأن كل نكرة تحتاج من أجل تعريفها إلى هذه

$$
\text { اللام إلا في حالات قليلة. }
$$

ب- لأنها قد نزلت منزلة الجزء مما تدخل عليه، أي أنها قد اتصلت بالاسم الاخلة

$$
\text { عليه اتصال بعض حروفه به. }
$$

ع - اجتماع المتقاربين فيما هو كالكلمة الواحدة أثقل من اجتماعهما في الكلمتين

المنفصلتين.

ه- يعود السبب إلى أن الأصوات السابقة تتصف بملمح الصفير الذي يعد قوة في

الصوت ،بالإضافة إلى أن صوت الضاد يتسم-زيادة على ملمـح الصفير - بملمـح التفخيم ، كما أن الثين يتسم بالإضافة إلى ملمح الصفير، بملمحي الاستطالة والتفشي اللذين يعدان صفتي قوة في الصوت. فهذه الملامح مكنت الأصوات المتصفة بها من التأثير في اللم ، زيادة على أن اللام وقعت ساكنة في نهاية مقطع، ووقعت الأصوات المجاورة لها متحركة

في بداية مقطع مما زاد من قوتها. ד - ويمكن القول إنهم أرادوا إدغام حرف التعريف في ما بعده؛ لأن الحرف المدغم أضعف من الحرف الساكن غير المدغم، ليكون إدغامه دليلا على شدة اتصاله وأقوى منـه 
عليه لو كان ساكنا غير مدغم؛ فلما آثروا إدغامـه في مـا بعده لمـا ذكرنـاه اعتبروا حروف المعجم؛ فلم يجدوا فيها حرفًا أثد مثاركة لأكثر الحروف من الللام. وعدلوا إلى اللام لأنها تجاور أكثر حروف الفم التي هي معظم الحروف، ليصلوا بذلك إلى الإدغام المترجم عما اعتزموه من شدة اتصال حرف التعريف بما عرفه؛ فيستدل بذلك على أنه قد نقله عن معنى التنكير إلى معنى التعريـف كمـا نقلت يـاء التحقير معنى التكبير، وأفادت التصغير، وكمـا أفادت ألف التكسير معنى الجمع بعد الإفراد، ولو جاءوا بغير الـلام للتعريـف لمـا أمكنهم أن يكثر إدغامها كمـا أمكنهم ذلك مـع الـلام. ويـلك على إيثارهم الإدغام لـلام التعريف -لمـا قصدوا من الإبانة عن غرضهم- أنك لا تجد لام التعريف مع واحد من هذه الأحرف الثلاثة عشر إلا مدغما في جميع اللغات، ولا يجوز إظهارها ولا إخفاؤها معهن مـا دامت للتعريف البتة، وأنك قد تجد اللام إذا كانت ساكنة وهي لغير التعريـف مظهرة غير مدغمـة مـع أكثر هذه الحروف الثلاثة عشر.

\section{ماشُرًاء التخثفيف بالثمبة}

ومما علل به أبو الحسن التخفيف بالغلبة:

$$
1
$$

ذكر أبو الحسن قلب الواو ياء عند وقوع الواو والياء متصلين في كلمـة واحدة

شريطة كون أولاهما ساكنة:" وأما الياء فلا تدغم في حرف صحيح، وقد تقدم سبب ذلك. و تدغم في الواو لأنها شابهتها في اللين والاعتلال، إلا أن الواو هي التي تقلب لجنس الياء، 


\section{د. حسن رمادي غانم نصر}

تقدمت أو تأخرت لأن القصد بالإدغام التخفيف، والياء أخف من الواو، فقلبوا الواو ياء على كل حال -وأيضًا فإن الياء من الثَّفة ، والياء من حروف الفم، وأصل الإدغام أن يكون

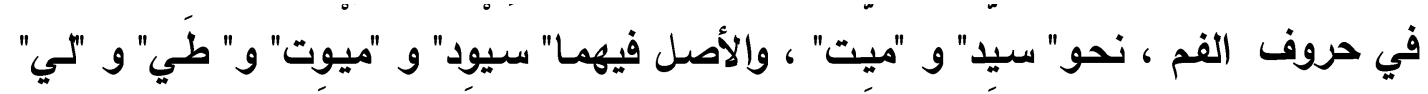

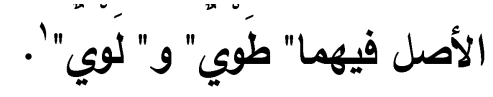

ويمكن القول إنه عندما تلتقي الواو و"الياء ويجتمعان في كلمة واحدة، والسـابق منهما ساكن وقبله كسرة، يجب قلب الواو ياء، تقدمت الواو، أو تأخرت لأنها أثقل من الياء

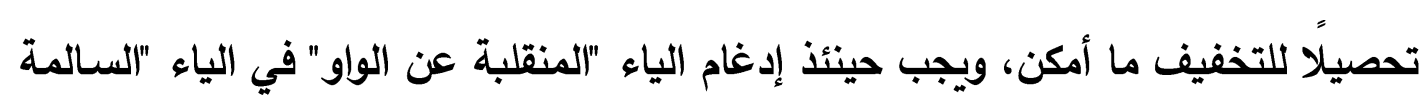

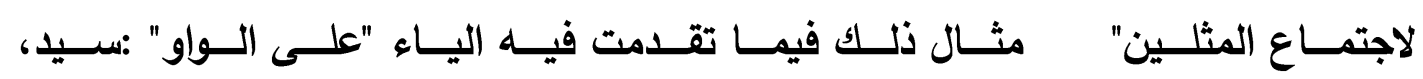
وميت، أصلهما :سيود، وميوت"، لأنهما من" ساد، يسود "|تفاقًا، و"مات، يموت "على إحدى اللغتين.

وأعلت الواو لكراهة التقائها مع الياء، فلما كانت الواو ليس بينها وبين الياء حاجز كان العمل من وجهه واحد وهو رفع اللسان من موضع واحد أخف عليهم ، وكانت الياء الغالبة في القلب لا الواو لأنها أخف عليهم.

وقعت الواو والياء بوصفهما نصفي حركـة متجاورتين، أولاهما في نهايـة مقطع وثانيتهما في بدايـة مقطع آخر كلاهما متوسط مغلق(ص ح ص) فأثرت الياء في الواو تأثيرا تقدميًا فحولتها إلى جنسها ، وهنا قلب الثاني إلى جنس الأول، وجاز هنا لأن الواو 
أثقل من الياء، ومن ناحية أخرى فإن الواو والياء صامتان ضعيفان يستثقل اجتماعهما معا.

ومثال ما تقدمت فيه الواو "على الياء" طي، ولي "بالتشديد" مصدرا: طويت ولويت، وأصلهما، طوي ولوي" ، بفتح أولهما وسكون ثانيهما، قلبت، الواو منهما ياء وأدغمت في الياء.

وقعت الواو والياء بوصفهما نصفي حركة متجاورتين ودونما فاصل بينهمـا داخل مقطع واحد من النوع الطويل المضـاعف الإغلاق(ص ع ص ص ص) وهنا أثرت الياء في الواو تأثيرا رجعيًا من أجل إغلاق المقطع بنصف حركة مضـاعفة ليكون نطقهم من وجها وإحد. ومن ناحية أخرى فإن الياء أخف من الواو وهذا يتماشى مع القصد من الإدغام وهو الخفة لأن اجتماعهما ثقيل ، وممكن أن الناطق شعر بضعف الواو والياء فأراد أن يقفل المقطع بصوت قوي فعد إلى التضعيف لأنه يقوي الصوت. المالة الهامنة أمن الابس

يقوم أمن اللبس على مبدأ الإفادة، فتحقيق أمن اللبس أهم مـا تحرص عليه اللغة لأن اللغة الملبسة لا تصلح أن تكون وسيلة للتفاهم والتخاطب، واللبس محذور لأنه يتنافى مع مقاصد اللغة ـ وأمن اللبس مظهر من مظاهر التخفيف لأنها يعطي للمتكلم الحريـة في صوغ الألفاظ ، وكثير من المسائل الصرفية تعود إلى هذا السبب، والعدول الذي يسببه أمن اللبس عدول مطرد طالما يخضع لقاعدة تصريفية يفرد بها الإعلال أو الإبدال أو النقل أو 


\section{د. حسن رمادي غانم نصر}

القلب أو الحذف أو الزيـادة، وتدور في فلك أمن اللبس عدة صور تطبيقية في الدرس الصرفي تجعل منه أصلاً من أصول التعليل .

ومن مسائل أمن اللبس التي نبه عليها ابن عصفور:

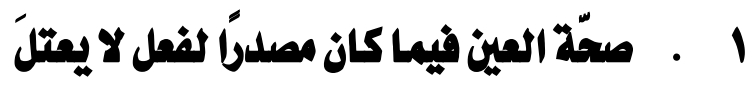

وممـا يمتــع فيـه الإعلال ممـا وسـمه أبو الحسن بالثذوذ، فـلا تقلب الواو والياء المتحركتان المفتوح ما قبلهما جملة من الألفاظ ، يقول أبو الحسن:" ولا تصـ العين في شيء مما جاء على وزن الفعل إلا فيما كان مصدرا لفعل لا يعتل، نحو" العور" و "الصَّيد"

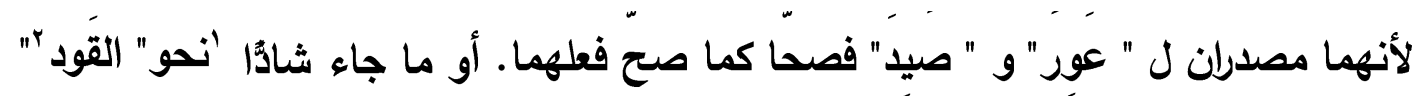
و" الحوكة"َ" و" روعِع" و" حولِ" فِإن العين صحَّت فيها، وكان القياس إعلالها ـ وفي ذلك منْبهة على ما ادعينا من أن الأصل في "باب" : " بوب" ، وفي" مال" : "مول" وأمثالهما؛. فإن قال قائل : لأي شيء لـم تجر هذه الأسماء التي هي على وزن الفعل على أصلها فتصح" ليكون ذاك فرقاً بينها وبين الفعل كما فعلوا ذلك فيما لحقته الزوائد ، فقالوا: " هو أطول منه" فصححوا فرقًا بينه وبين" أطال"؟ فالجواب أن مـا لحقته زيـادة من الأسماء تبلغ به زنة الأفعال لا ينصرف، فلو أعللته لالتبس بالفعل لأنـه لا ياخله خفض ولا تنوين

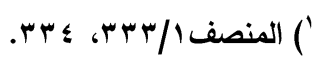

$$
\begin{aligned}
& \text { r) (القود: قتل النفس بالنفس وهو القصاص، لسان العرب(قود) } \\
& \text { “'الحوكة: جمع حائك، ورجل حائك من قوم حاكة وحوكة ،لسان العرب(حوك) و (حيك). }
\end{aligned}
$$

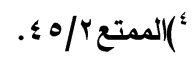


كما أن الفعل كذلك، وما كان على ثلاثة أحرف فالتنوين والخفض يفصلان بينه وبين الفعل، فأمن اللبس"' . ويمكن القول:

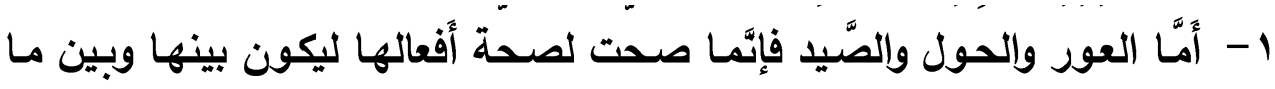

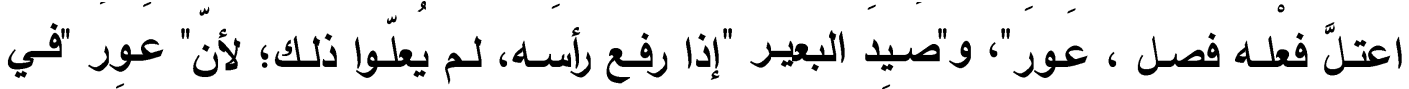

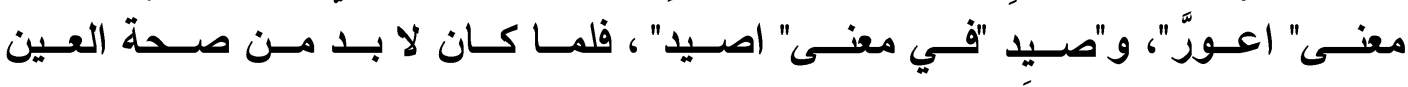
في" اعورَّ "و "اصيدّ "لسكون ما قبل الواو والياء فيهما، صححوا العين في" عَور"، و"صِيدَ؛؛ لانّهمـا في معناهمـا وكالأصل. وتُحذف الزوائد لضرب مـن التخفيف، فجعل صحةُ العين

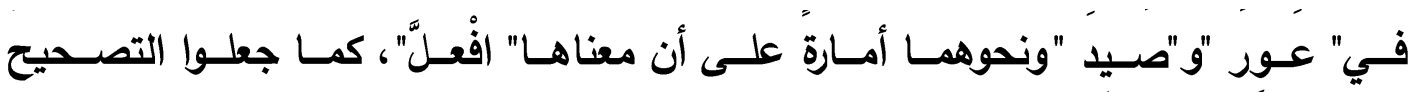

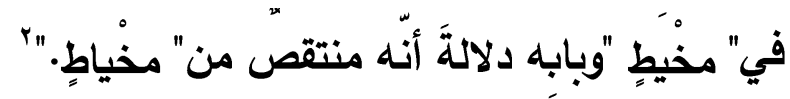
أي أن تصحيح هذه الأفعال مراعاة للمعنى؛ لأنها في معنى فعل آخر جاء صحيحا

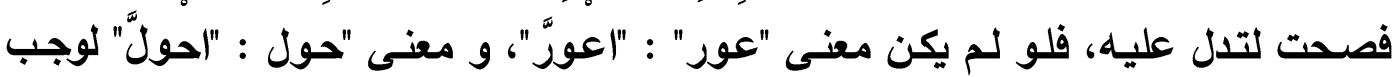
إعلالهما كما أعل (خاف و هاب) لما لم يقل في معناهما (فعلَّ) نحو(اخوفَّ واهيبَّ). r - كل ما جاء شادُّا فهو من الأسماء دون الأفعال، فالإعلال في الأفعال أقوى منه في الأسماء. ץ- مثل" عور "، و"صيد" :"اعتونـوا "و "اهتوشـوا"، و"|جتوروا"، صحت الواو فيها؛ لأنّها بمعنى" تَعاونوا"، و"تَهاوشوا"، و"تَجاوروا" .وكان قياسها أن تعتل فيقال فيها: اعتانوا، 'الممتع r/0 ؛.

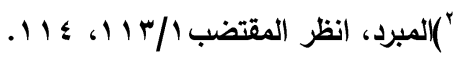




\section{د. حسن رمادي غانم نصر}

واهتاشـوا واجتاروا، حمـلًا على غيرهـا مـن الأفعـال نحو: اختـاروا واقتـادوا واعتادوا، وهذه الأفعال محمولة في إعلالها على الثلاثي: خار، وقاد ، و وعاد، وحار، ولكن النحاة فسروا مجيئها مصححة على الأصل بأنها في معنى لا بدَّ من صحته، أو في معنى يخرج على الأصل وهو معنى (تفاعلوا): تجاوروا، وتعاونوا، وتهاوشوا.'

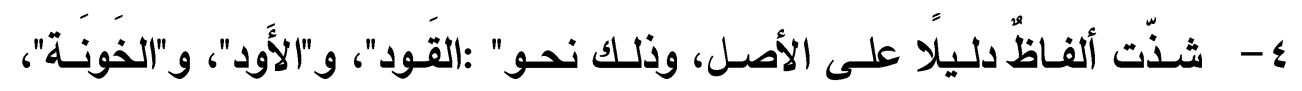
و"الحوكَة"، كَأنهُم حين أرادوا إخراج شـيء من ذلك مصدَّحا تتبيها على الأصل، تَأولوا الحركةَ بأن نزّلوها منزلة الحرف، فجعلوا الفتحة كالألف، والكسرة كالياء، وأجروا" فَعلًا "بفتح

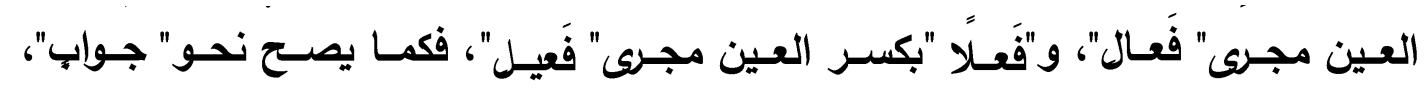

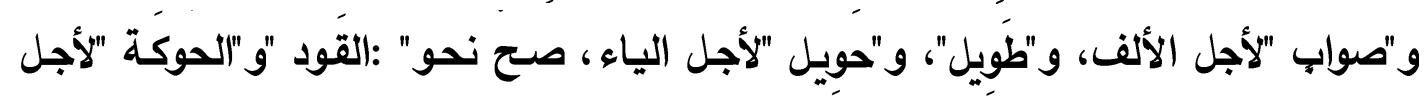
الفتحـة، و"حَول"، و"عَور "لأجل الكسرة. فكانت الحركة التي هي سبب الإعلال على هذا التأويل سببا للتصحيح، ." . . ' ه- مسألة الإعلال والتصحيح في (عين) هذه الأفعال من الاختلافات اللهجية، فقد نسب التصحيح إلى أهل الحجاز فهم يقولون " حول يحول و صيد يصيد، وتميم يعلّون هذه الأفعال فيقولون: حال يحال و صاد يصادّاّ.

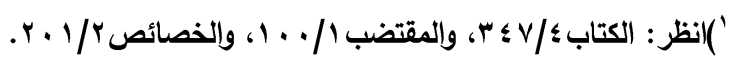

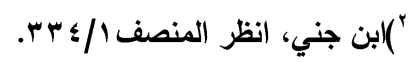

$$
\begin{aligned}
& \text { ") ابن منظور، انظر اللسان، مادة(حول)، و (عور). }
\end{aligned}
$$


צ- سبب هذا التصحيح هو التنبيه على الأصل ليكون دليلًا على الأصول المغيَّرة، وهو من باب "المخالفة الكمية"، إذ لمـا كان القياس هو إعلال هذه الواو والياء فصـار الناطق يبحث عن مخالفة الكثرة في الكمية.

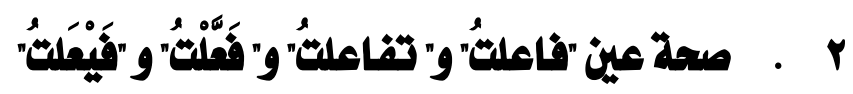

يرى أبو الحسن عدم اعتلال نحو "سـايرت" و "تسـاير" و "عاونتـ" و"تعاون" و "قومتهه" "ميَّزتهُ": "إٕٕنما لم تعتل العين لأن مـا قبلها سـاكن. فلو أسكنتها لالتقى سـاكنان فيجب الحذف فيصير لفظ "فاعل" كـ "فَاعل" نحو" ساير" ،لو قلبت الياء ألفًا ثم حذفتها لالتقاء الساكنين لقلت "سار" .

وكذلك "فََّّل" و "فَيَعل" لو أعللت العين فقلبتها ألفَاً ثم حذفتها أو الساكن قبلها لصـار اللفظ بهما كاللفظ ب "فَعل" أو" فَعل" ،فكنت تقول في" ميَّز" و "قوَّم" ، لو حذقت الساكن الأول بعد إعلال العين "ماز" و "قام"، ولو حذفت العين لقلت "ميز" و "قَوم"' . ويمكن القول إنه لما كان الإعلال يؤدي إلى الحذف والإلباس لم تُعلَّ شيئًا من ذلك. إلا أنك تقلب الواو ياء في "فَيعل" مما عينه واو -لاجتماع الياء والواو، وسبقي الياء بالسكون -فتقول في "فَيَعل" من "القول "'قيََّّل". 


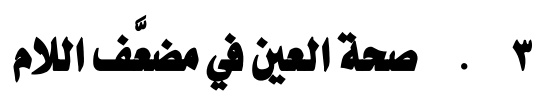

يمتـع الإعلال بالنقل، فـلا تنقل حركة عينها إلى السـاكن الصـيح قبلها، ويجرى

التصحيح في مضعَّف اللام منعا للالتباس، يقول أبو الحسن:" وإن كان علة وزن "(فعل" أو "(فعال" نحو "ابيضّ" و "ابياضّ" و "تعور" و "اعوارَّ" فإن العين تصح ولا تعتل، وإنما لم تعتل لأنك لو أعللت "(بيض" و "اعورَّ" لقلت "باصَّ" و "عارَّ" فيلتبس ب "فاعل" ، وذلك أنك كنت تنقل الفتحة من الياء والواو إلى الساكن قبلهما، ونحذف ألف الوصل لزوال السـاكن وتقلب الواو والياء ألفًا بتحركهما في الأصل وانفتاح ما قبلهما في اللفظ. وكذلك لو أعللت "ابياض" و "اعوار" للزمك أن تقول "باصَّ" و "عارَّ" فيلتبس ب "فاعلَ" وذلك أنك إذا فعلت بهما مـا فعلت ب "(فعلَّ" التقى ساكنان: ألف "(فعال" والألف المبدلة، فتحذف إحداهما، فيصير اللفظ" باضَّ" و "عارَّ"' . ويمكن القول:

ا- صحت عين المضاعف نحو : ابياصَّ واعِار واستوادّ لأنـه لو أعل لأدى إلىى

اللبس؛ إذ لو قلبت الواو ألفًا ، أو قلبت الياء ألفًا ونقلت حركتهما إلى ما قبلهما كان يسقط همزة الوصل وإحدى الألفين ، فيبقى: باصٌٌ، و عارِّ، وسـادٌ، فيلتبس بفاعل المضـاعف، فنحو :باصَّ -على سبيل المثال - يد يظنٌ أنه اسم فاعل من البضاضة، أي نعومة البشرة'. r- أضيف على ما قاله ابن عصفور بأن المانع هو خوف اللبس فيمـا لو أعل،

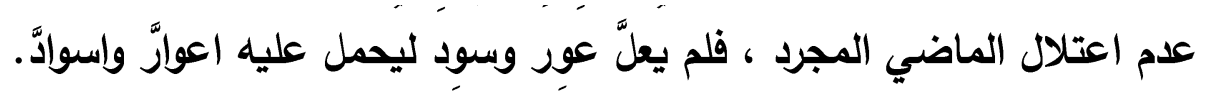

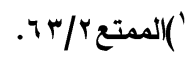

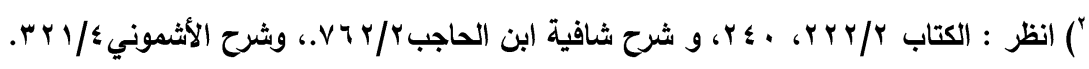

(حولية كلية الآداب- جامعة بني سويف عدد خاص - يناير (r.T) 


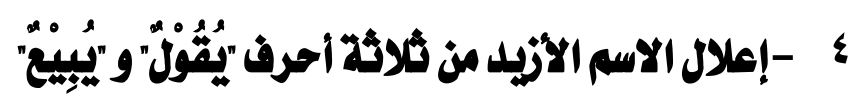

الإعلال لأمن اللبس تارة، وعدم الإعلال لأمن لبس الاسم بالفعل في حالة أخرى،

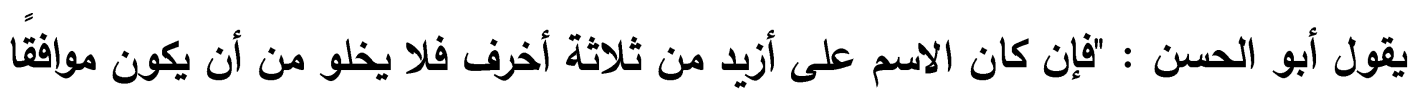
للفعل في وزنه أو لا يكون. فإن كان موافقًا للفعل في وزنه-وأعني بذلك أن يكون عدد حروفه موافقًا لعدد خروف الفعل، وحركاته كمركاته وسكناته كسكناته، فلا يخلو نت أن يكون موافقًا للفعل في جنس الزيادة، أو تكون زيادته مخالفة لزيادة الفعل. فإن كان موافقًا

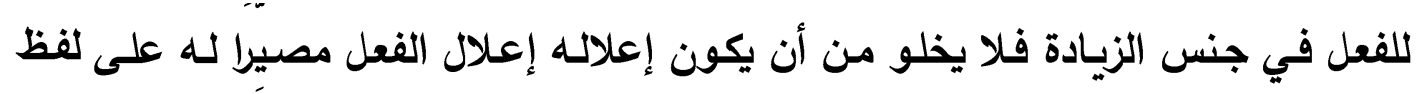

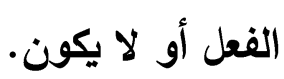

فإن لم يكن مصبِراٍ لـه على لفظه أعلاتهـه لأمن اللبس وذلك نحو: أن تبنـي من

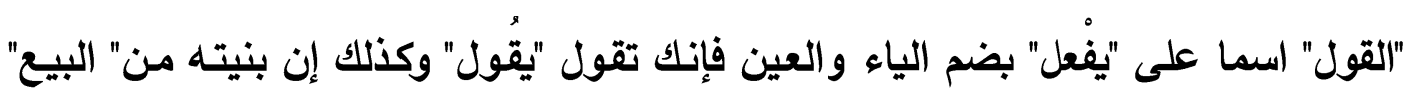
قلت" يبيع"، والأصل "يبيع"." فنقلت الضمة من الياء إلى الباء فصارت الياء سـاكنة بعد ضمة، فقلبت الضمة كسرة لتصح الياء كما فعلوا في "بِيض" و "مبيع" في مذهب سيبويه في إعلالهما ـ هذا مذهب جماعة النحويين...لكونه) ليس مبنيًّا على فعل' . ويمكن القول إن الصحيح ما ذهب إليه الجماعة من أنك تعل لموافقته الفعل في الوزن وإن لم يكن مبنيَّا على الفعل. 


\section{د. حسن رمادي غانم نصر}

\section{- - ملدم الإعلال لأمن لبس الاسم بـاكفمل}

يزى أبو الحسن عدم الإعلال لأمن لبس الاسم بالفعل ، فيقول: " وإن كان الإعلال مصيرا له على لفظ الفعل لم يعل لئلا يلتبس الاسم بالفعل، وذلك نحو قولك "هذا أطول منك" ، ألا ترى أنك لو أعللت فقلت "أطال" لالتبس بلفظ الفعل.

وكذلك لو بنيت مثل "يفْعل" و "تَفْعل" من القول والبيع لقلت: "يقُول" و "يبيـع" و "تَقْول" و "تبِيع" ، وكذذلك أيضًا لو ألحقت التاء لم تعتد بها، وصحصت الاسم فكنت تقول

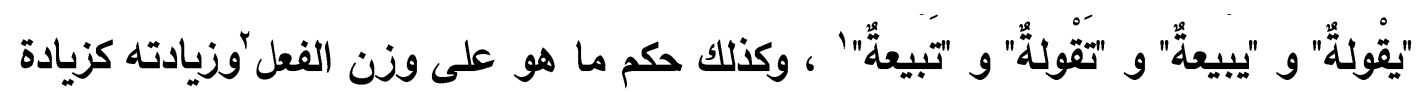

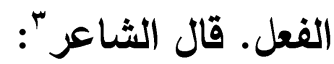

دسَم السَّليط على فَتَيل ذُبِالٍ جاؤوا بتدورِِ يضيء وجوهنا فأمـا "يزيـد" اسم رجل فإنمـا اعتل من قبـل أنـه كان فعلَا لزمـه الإعلال، ثم نُقل منالفعل فسمي به. فهو في المعتل نظير "يثكر" في الصحيح. وكذلك "تزَّدِ" بالتاء؛ قال أبوذؤُبب '

$$
\begin{aligned}
& \text { (To/r) }
\end{aligned}
$$

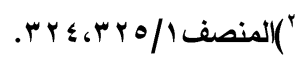

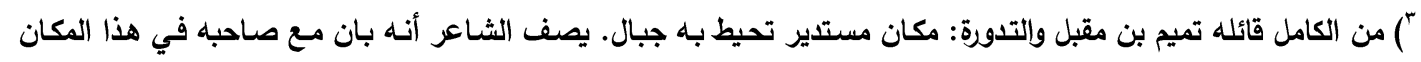

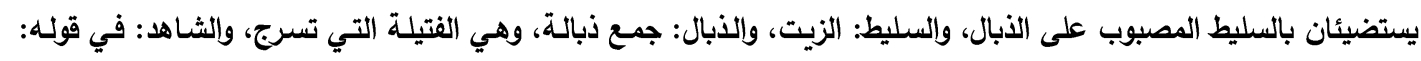

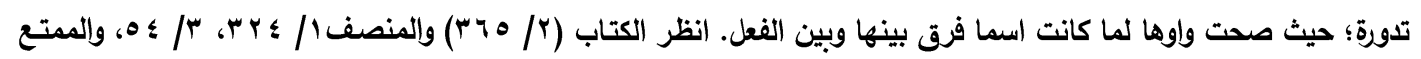

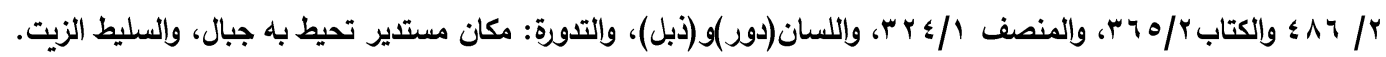

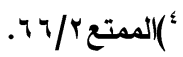




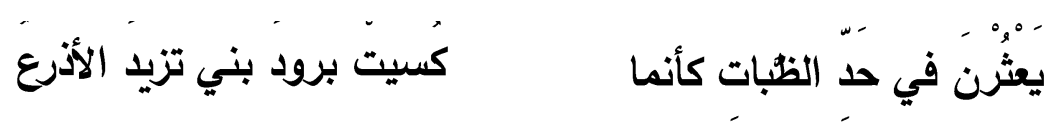

ويمكن القول إن كان الاسم على أزيد من ثلاثة أحرف فإمـا أن يكون موإفقًا للفعل في وزنه، أو لا يكون؛ فإن كان موافقًا للفعل في وزنه وأعني بذلك أن يكون عدد حروفه موافقًا لعدد حروف الفعل، وحركاته كمركاته، وسكناته كسكناته فلا يخلو من أن يكون موافقًا للفعل في وزنه جنس الزيـادة، أو تكون زيادته مخالفة لزيـادة الفعل فإن كان موافقًا للفعل في جنس الزيادة لم يعل لئلا يلتبس الاسم بالفعل، وذلك نحو قولك :هذا أطول منك، لو أعللت فقلت :أطال بلفظ الفعل، وكذا لو بنيت مثل تفعل أو تفعل من القول والبيع قلت :تقول وتبيع، وتقول وتبيع، وكذلك أيضّا لو ألحقت التاء لـم يعتد بها وصـحت الاسم، فكنت تقول : يقولة و يبيعة، و تقولة وتبيعة وكذلك حكم مـا هو على وزن الفعل وزيادته كزيادته .

أما يزيد اسم رجل فإنما اعتل من قبل أنه كان فعلا فأعل لزومـا، ثم نقل من الفعل فسمي به وإن كان مخالفا في جنس الزيادة، فإنه يعل إعلال الفعل الذي يكون على وفقـه في الحركـات وعدد الحروف؛ لأنـه قد أمـن التباسـه بالفعل، فتقول في مفعل مـن القـول والقيام :مقال ومقام والأصل: مقول ومقوم، فأعلتهما كما أعللت :يخاف وكذلك: مفعلة من

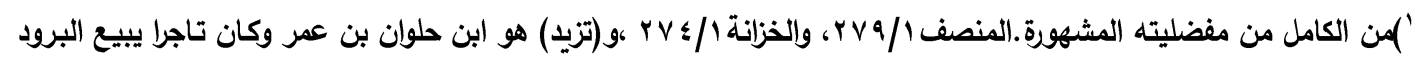
بمكة، يصف أبو ذؤيب أتنا صبغتها طرائق الاماء. 


\section{د. حسن رمادي غانم نصر}

البيع تقول فيها: مبيعة، فتنقل الكسرة من حرف العلة إلى الساكن قبله، كما فعلت ذلك في

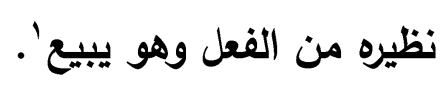

7

\section{وتثنية المقصور بثثنية المثقوص}

يدفع أبو الحسن مسائل قياسية محتجَّا بتجنب الالتباس، فهو يحتج بصحة الواو أو الياء ، حيث يقول: "فإن كان ما قبل حرف العلة حركة فلا يخلو أن تكون الحركة فتحة

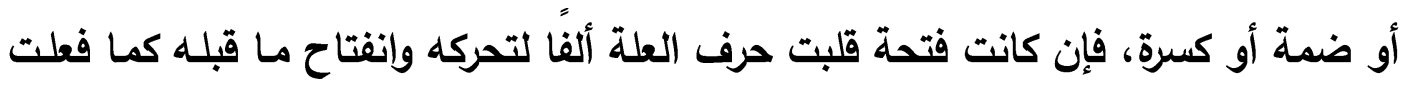
ذلك في الفعل، تطرَّف حرف العلة نحو "عصا" و "فتى" ، أو لم يتطرف نحو "قطاة". كما جعل أبو الحسن ما يمتنع فيه إعلال الواو والياء المتحركين ما قبلهما إن كانت

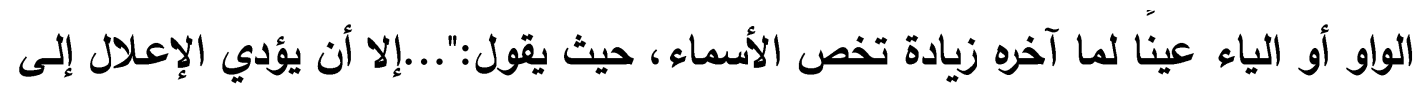

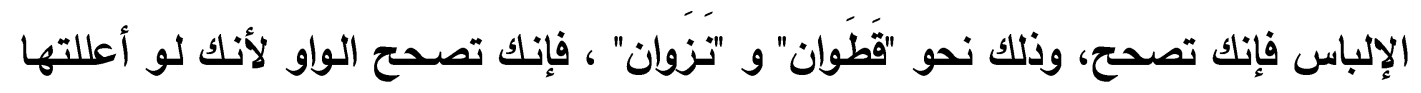

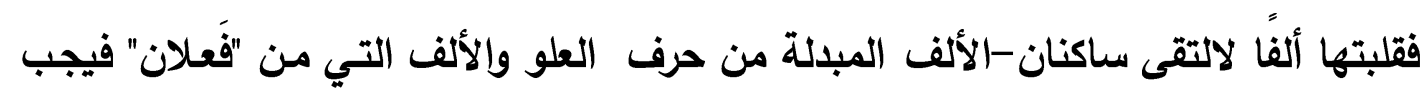

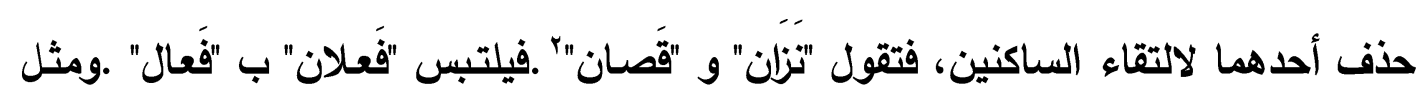

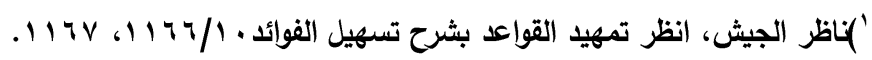

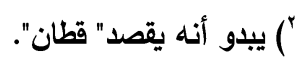

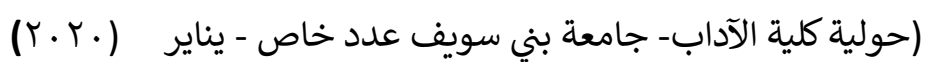


ذلك "رحيان" و "عصوان" صححت لأنك لو أعللت لحذفت لالتقاء الساكنين، فكان يلتبس تثنية المقصور بتثنية المنقوص فيصير "رحان" و "عصان" ك "يدين" و "دمين" ".. ويمكن القول إن أبا الحسن يحتج لصحة الـاو أو الياء في "نزوان" و "رحيان" باللبس ، فيلتبس تثنيـة المقصور بتثنيـة المنقوص، فيصير: رحسان وعصسان ، كيدين و دمين، ويمكن القول أيضًا إن اللام بالتغيير أولى، و لو قلب لزم الحذف، فيلتبس فَعلان بفَعال، إد يبقى نتزان وغَلانَ.

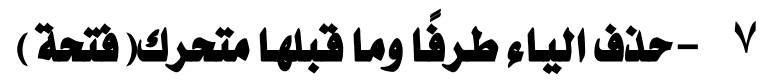

يقول أبو الحسن: " ....وإن كانت بعد حرف فـلا يخلو نت أن تكون طرفًا أو غير

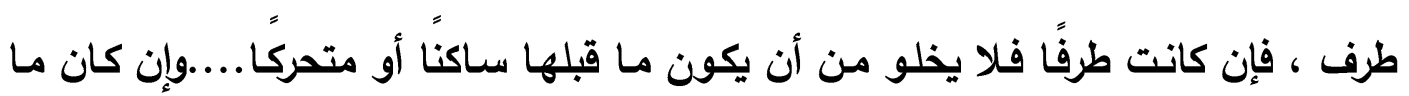
قبلها متحركَا فإنـه لا يخلو أن تكون الحركة فتحة أو ضمة أو كسرة ...وإن كانت فتحة قلبت ألفًا نحو "علقى" و "قلسى" ، والأصل "علقي" و " قلسي" ، بدليل قولك "علقيان" و "قلسيت" لكن لما تحركت الياء وقبلها فتحة قلبت ألفاً. مـالم يمنع من ذلك الألف التي هي علامة الاثنين أو ضميرهما نحو "قلسيا" و" علقَان" فإنها تثبت ولا تقلب لئلا يؤدي ذلك إلى اجتماع ساكنين - الألف المبدلة من الياء والألف التي بعدها-فيلزم الحذف فتقول "قلسى" 


\section{د. حسن رمادي غانم نصر}

فيلتبس بفعل الواحد، و "عَقان" فيلتبس بتثنية غير المقصور إذ قد يتوهم أنه تثنية " علْق" مثلاً"' . n

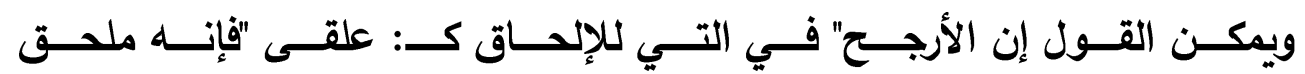

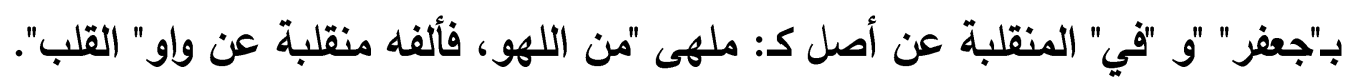

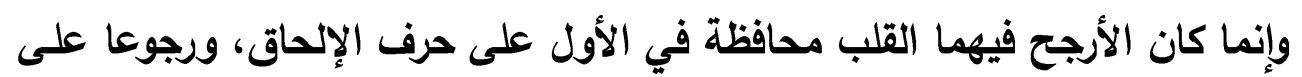

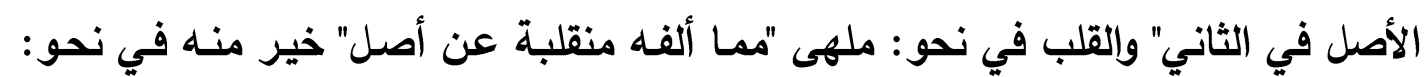

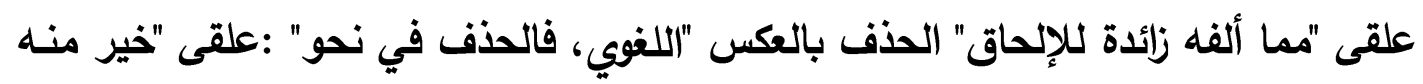

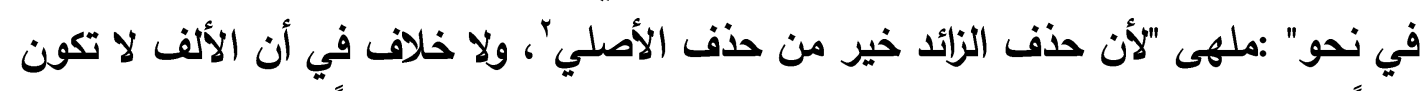

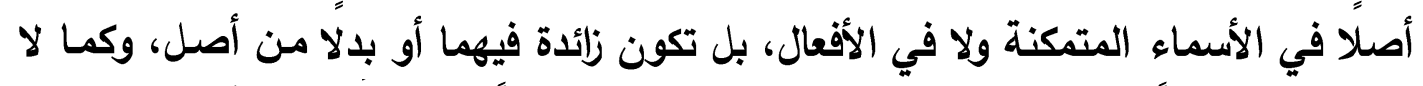

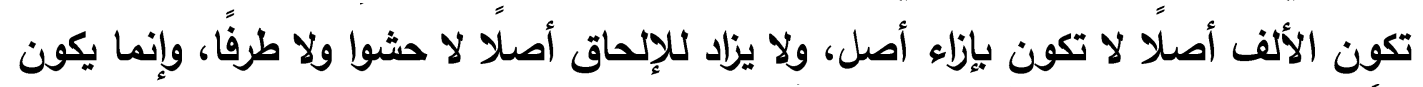

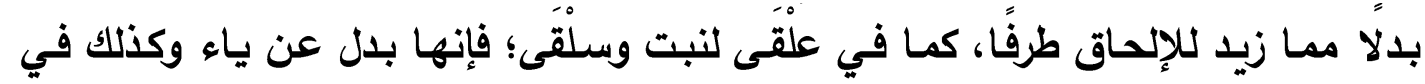

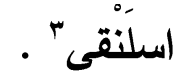

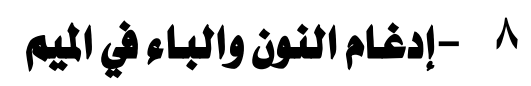

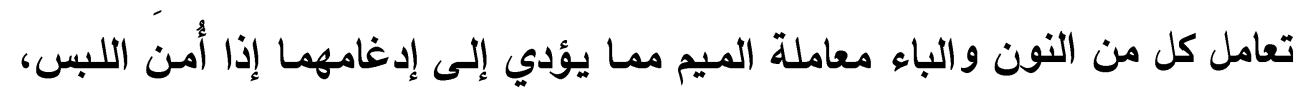

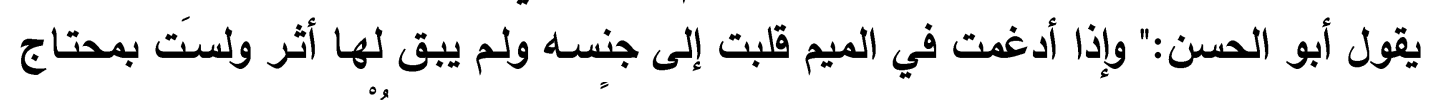

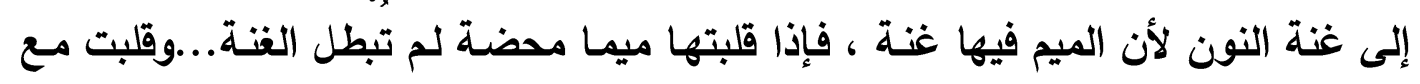

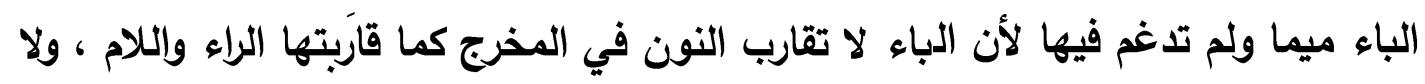

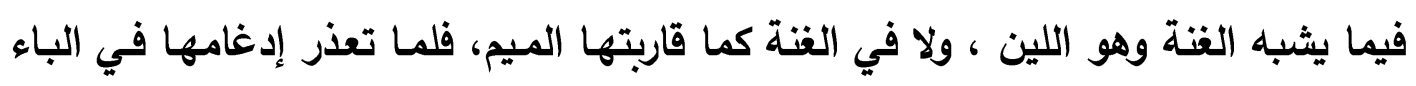

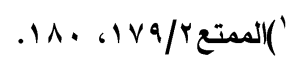

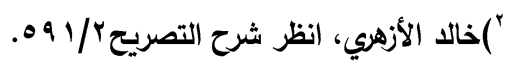

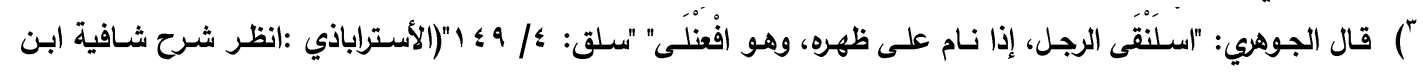

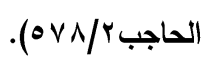

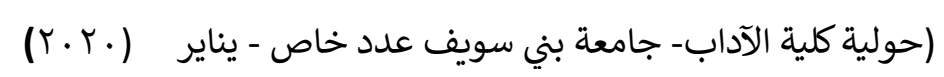




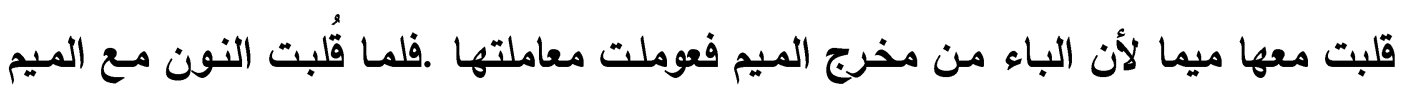

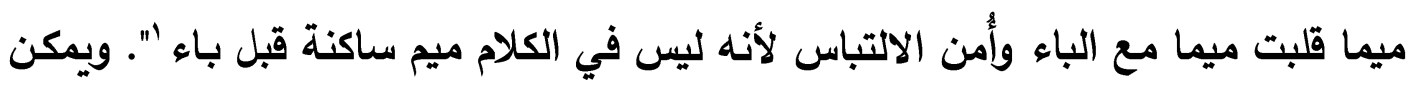

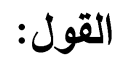

1- إن النون تتعرض إلى القلب إلى ميم إذا وقعت مجاورة لصوت الباء، ويعود

السبب في قلبها ميما وعدم إدغامها في الباء إلى بعد المخرجين من جهة، والتباين في الصفات من جهة أخرى، وقوى عملية القلب أن الباء والميم متحدتان في المخرج ، وقد جاز قلب النون إذا جاورت الميم ميما مما أدى إلى معاملة الباء معاملة الميم. فالنون تتأثر بالباء وتقلب إلى صوت أنفي شبيه بالباء في المخرج وهو الميم، أي أن النون تفقد مخرجها ولكن لا تفقد صفتها الأنفية.

ץ- أما إدغام النون في الميم، فالميم وإن كانت من بين الثفتين، فقد ضارعت النون في الغنة. فلما اشتركتا في الغتة، وتقاربتا في المخرج بعض التقارب، وجب الإدغام.

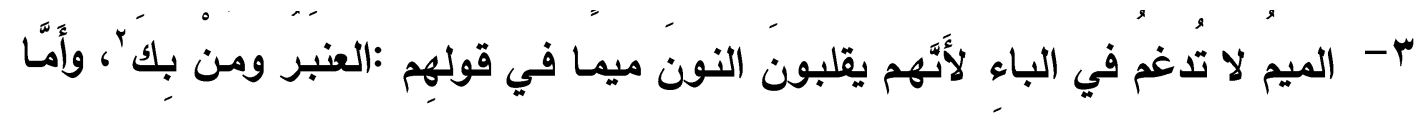

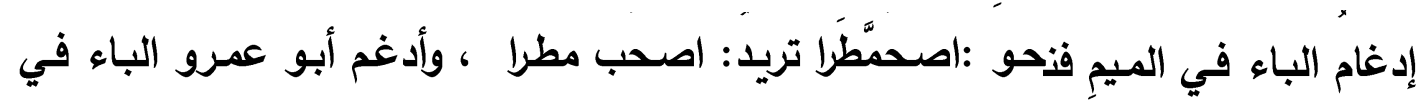

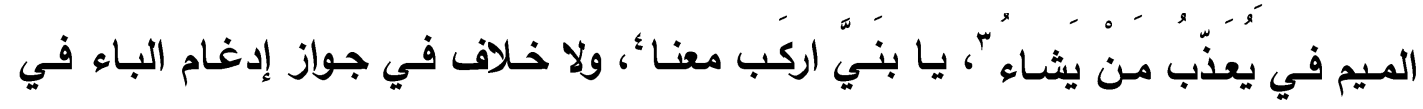

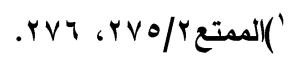

$$
\begin{aligned}
& \text { r) في الأصل: من "يدالك" والذي يعنيه بالعمبر في العنبر . وممبك في من بك. }
\end{aligned}
$$

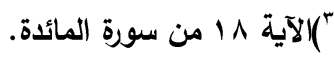

$$
\begin{aligned}
& \text { ؛ الآية ب ؛ من سورة هود. }
\end{aligned}
$$


الميم.وروي عن أبي عمرو أنه كان يدغم الميم في الباء إذا تحرك ما قبل الميم مثل ( مريم

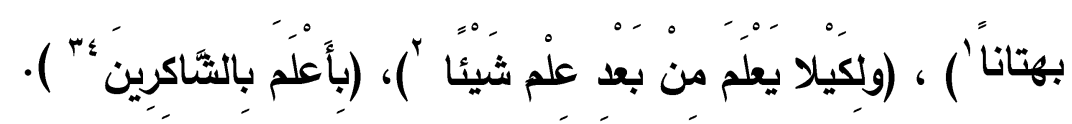

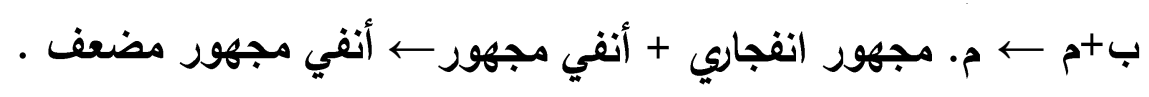
أثر صوت الميم المتسم بالغنة والجهر في صوت الباء المتسم بالجهر والانفجار تأثيرا رجعيًا فحوله إلى جنسه وذلك لأن صوت الميم وقع متحركًا في بداية مقطع مما زاد في قوته ، في حين وقع صوت الباء ساكنًا في نهاية مقطع فضعف بموقعه، إضافة إلى أن كلا الصوتين من مخرج واحد، وقد تحقق في مثل هذا التحول تجانس الصوتين في المخرج والصفة، حيث انتقل صوت الباء من مخرجه إلى مخرج الميم فاكتب صفة الغنة.

\section{9}

الإدغام في "امَّحى" من قبيل إدغام المتقاربين لا من قبيل إدغام المثلين، ويرى أبو

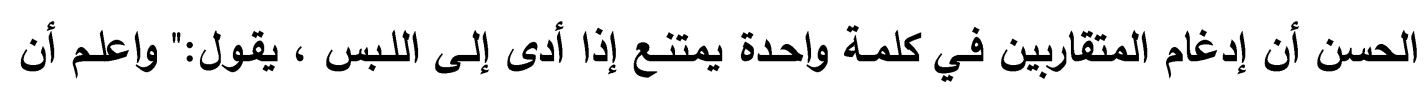
الإدغام في المتقاربين إنما يجوز إذا كانا من كلمتين لأنه لا يلتبس إذ ذالك بإدغام المثلين لأن الإدغام فيما هو من كلمتين لا يلزم، بل يجوز الإظهار فيكون في ذلك بيان للأصل.

$$
\begin{aligned}
& \text { 'الآية } 104 \text { من سورة النساء. }
\end{aligned}
$$

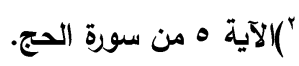

$$
\begin{aligned}
& \text { (") الآيةتهم من سورة الأنعام. }
\end{aligned}
$$

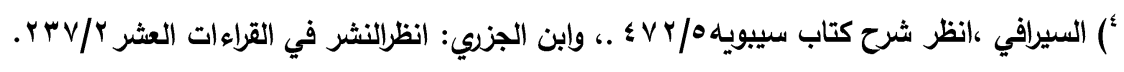

( احولية كلية الآداب- جامعة بني سويف عدد خاص - يناير (.T.T) 
فإن اجتمع المتقاربان في كلمة واحدة لم يجز الإدغام لما في ذلك من اللبس بإدغام

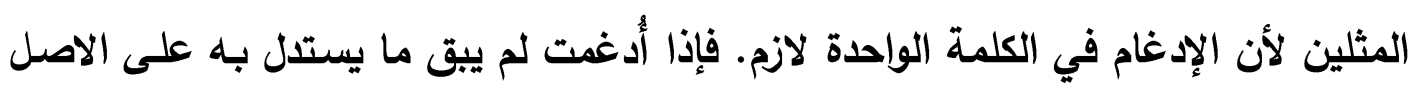

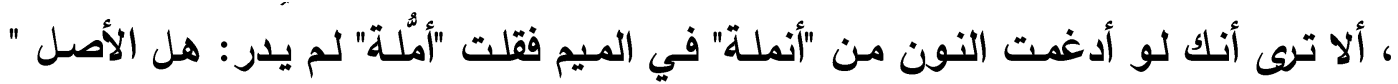

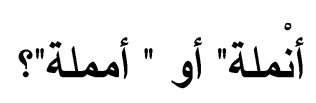

ولأجل اللبس الذي في إدغام المتقاربين من كلمة واحدة بينت العرب النون

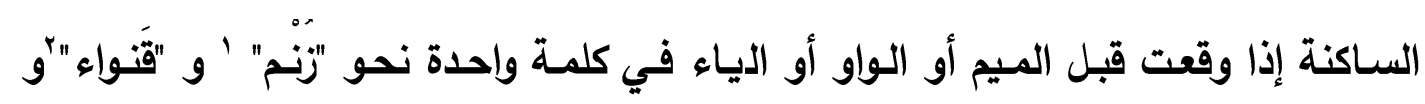
"كُنية" ، ولم تُخفها كما تفعل بها مـع سائر حروف الفم أن الإخفاء يقربها من الإدغام

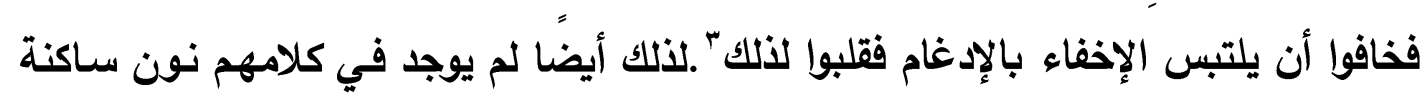

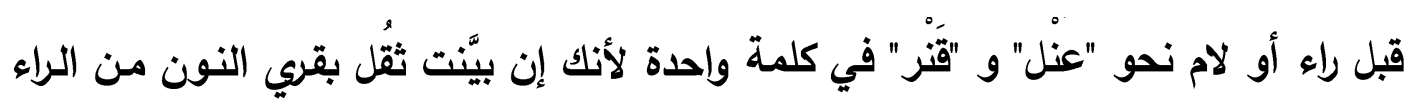
واللام، وإن أدغمت التبس بإدغام المثلين §".

ويمكن القول إن وجد حرف مضعف ينبفي أن يكون من إدغام المثلين، إلاّ أن يقوم

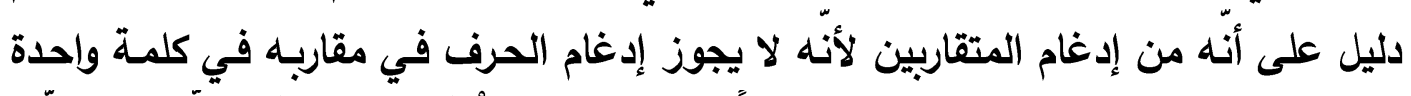

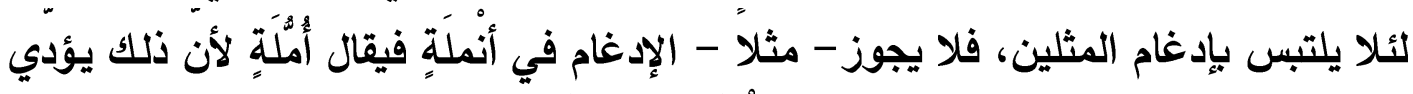

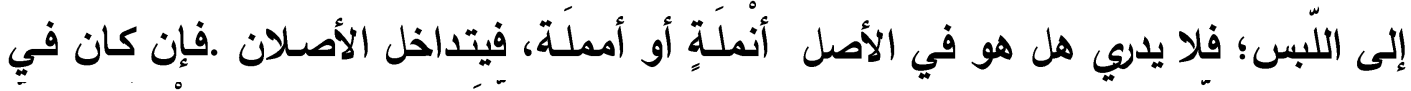

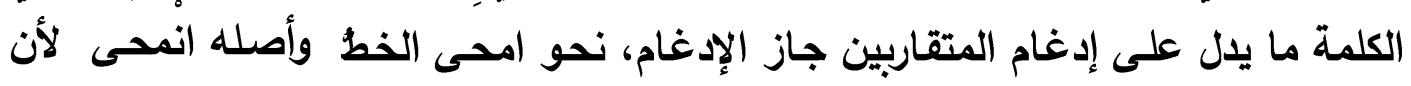

') زنم : جمع زنماء، وهي الثاة التي لها زنمة. ") بالتنواء: المدوبة الأنف.

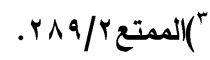
(4) 


\section{د. حسن رمادي غانم نصر}

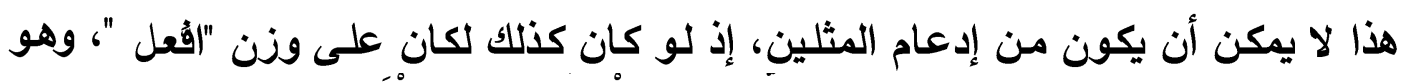

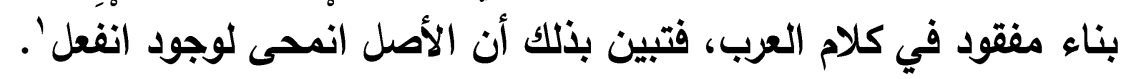
لذا أورد ابن عصفور جواز إدغام المتقاربين في كلمة واحدة في نحو (انفعل)

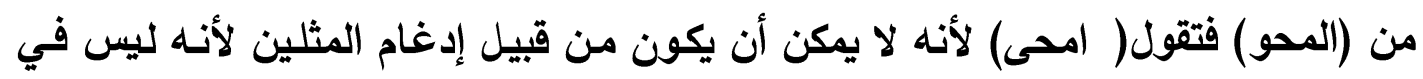

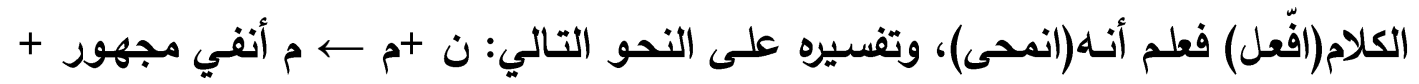
أنفي مجهور

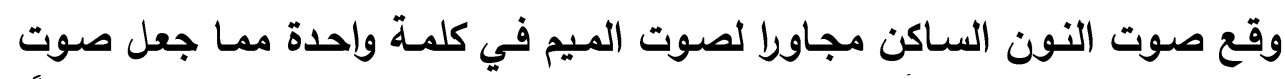

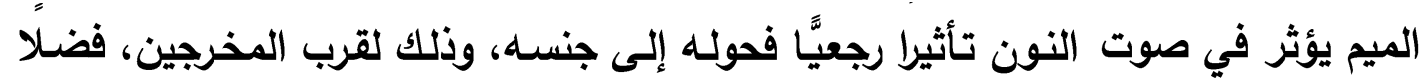

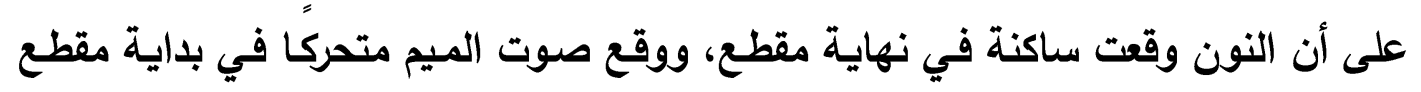

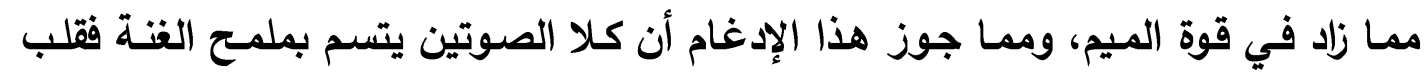
النون ميما لم يؤثر لأنها حولت إلى أغن مثلها، فتحققت مماثلة صوتية في المخرج.

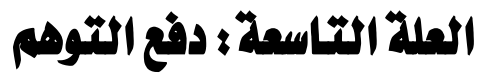

من العلل الصرفية التي علل بها أبو الحسن علة دفع التوهم وذلك في:

$$
\text { ا } 1
$$

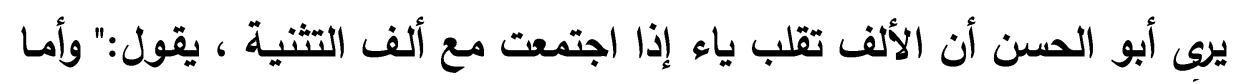

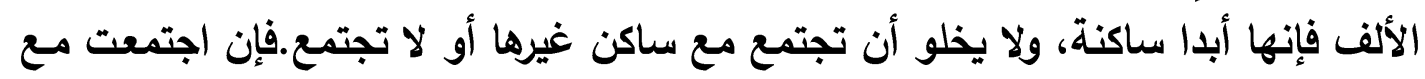

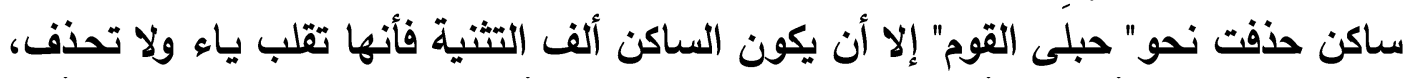

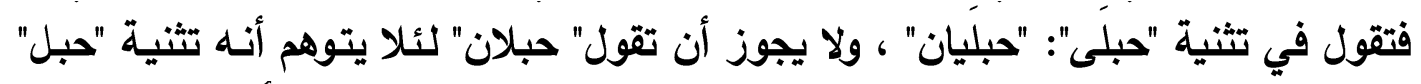

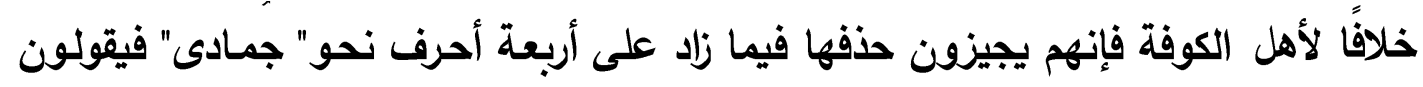

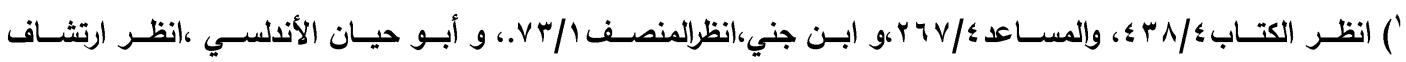

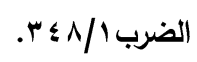

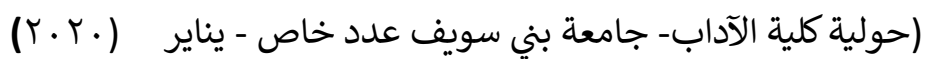


في تثنيتـه" جمـادان" ، والصـحيح عنــنا أنـهـ لا يجـوز إلا "جماديـان" ، وبـهـ ورد السـماع. قال 'شهري ربيع و جماديينه".

ويمكن القول إن الألفف إن اجتمعت مـع سـاكن حذفت إلا أن يكون السـاكن ألفف

التثنية فإنها تقلب ياء ، فيقال في تثنية (حبلى):(حبليان) ، ولا يجوز أن نقول (حبلان) لئلا يتوهم أنه تثنية(حبل) خلافًا لأهل الكوفة.

وبهذا تقلب الفتحة القصيرة التي قبل مورفيم التثنية إلى نصف حركة ليتدئ بها

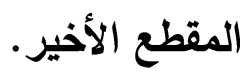

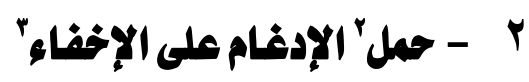

ذكر أبو الحسن ما أدغمه القراء على غير قياس ، وما جاء من ذلك ما يوهم أنه إدغام فإنه يحمل على الإخفاء، ومن ذلك:

\section{ا}

يقول أبو الحسن:" هذا باب يـذكر فيه مـا أدغمته القراء ممـا ذُكر أنـه لا يجوز إدغامـه. فمن ذلك قراءة أبي عمرو(الرعب بما) بإدغام باء (الرعب) في الباء التي بعدها، مع أن قبل الباء حرقًا ساكنا صحيحا، وقد تقدم أنه لا يجوز عند البصريين.

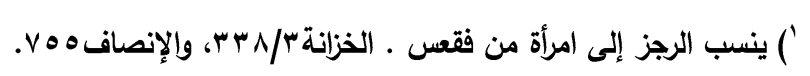

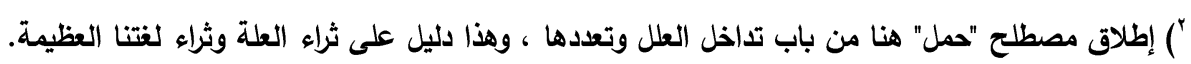

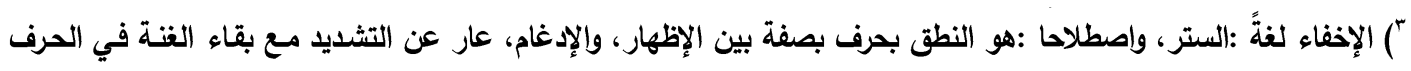

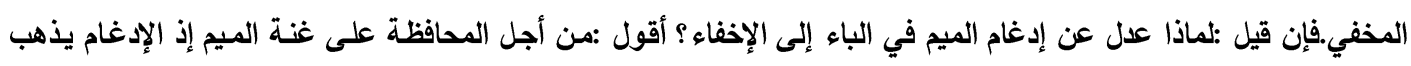




\section{د. حسن رمادي غانم نصر}

وحملوا قراءة أبي عمرو على الإخفاء، وقد تقدم أن الإخفاء يسمى إدغاما'".

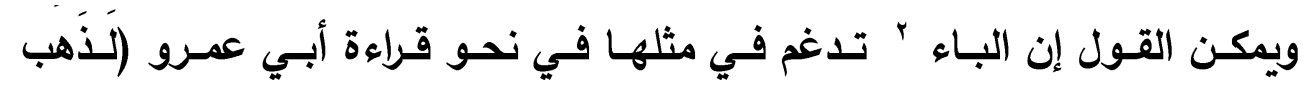

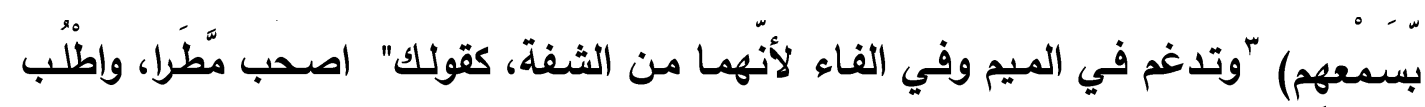

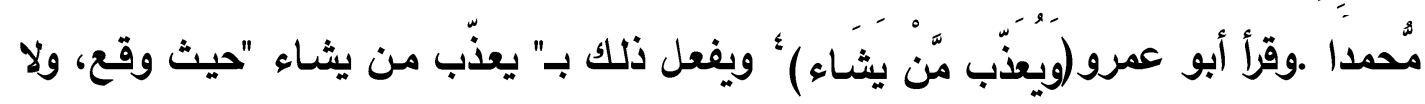

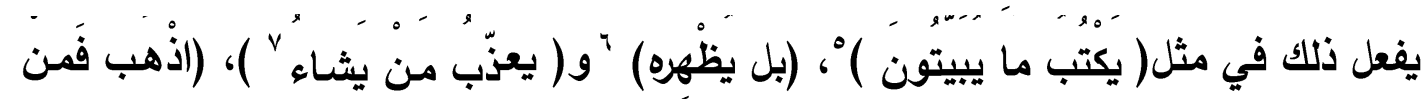

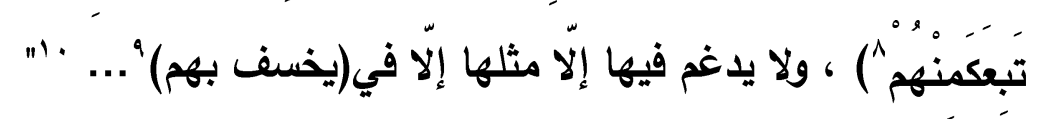

وخـص الأول بالإدغـام مـن قبـل أنــه لا يكـاد يقــع في القـرآن إلّا وقبـــه أو بعـده

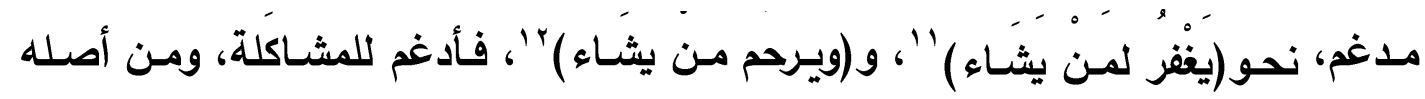

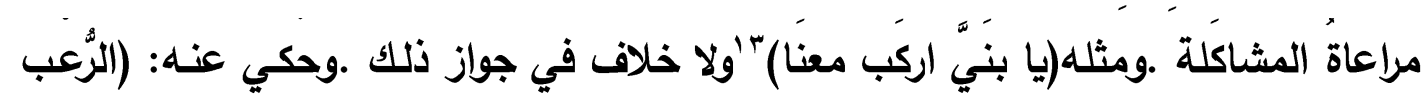

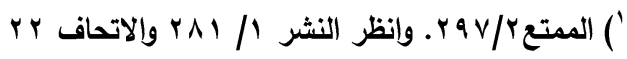

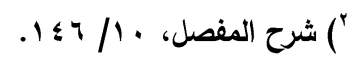

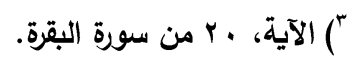

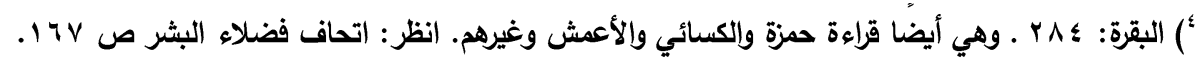

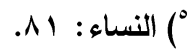

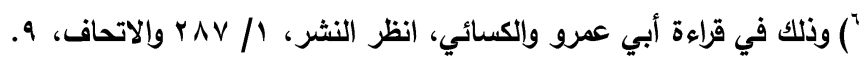
الآلآية . ك من سورة المائدة.

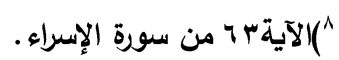

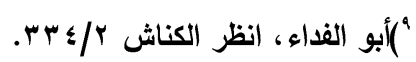

·') الآية 9 من سورة سبأ.

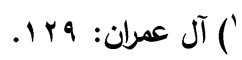

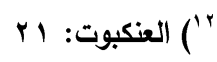

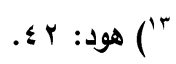


بمَا أَشْرَكُوا بالَّه)'، بالإدغام، وهو غير جائز عند البصريين للجمع بين ساكنين على غير شرطه وصحة محمله على الإخفاء، وأجازه الكوفيون.

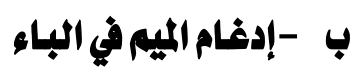

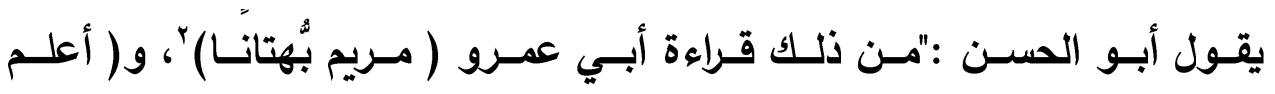

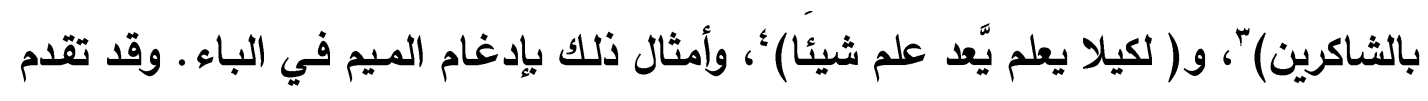
أن الميم مـن الحروف التي لا تدغم في مقاربها، وينبغي أن يحمل ذلك على الإخفاء،

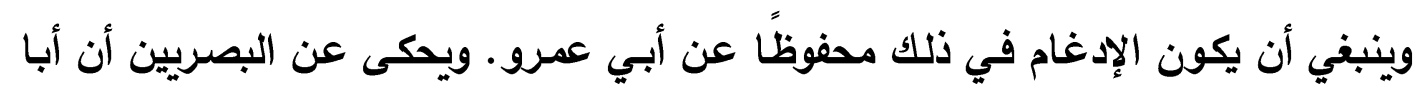
عمرو كان يختلس الحركة في ذلك، فيزى من يسمعه- ممن لا يضبط سمعه- أنه أسكن

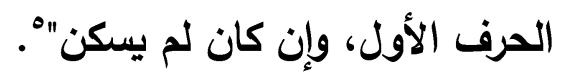

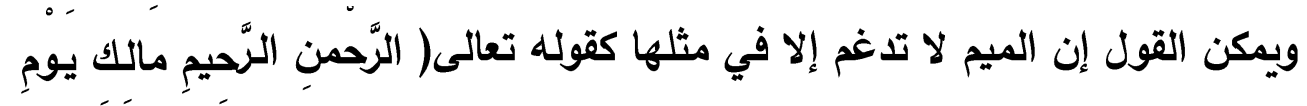

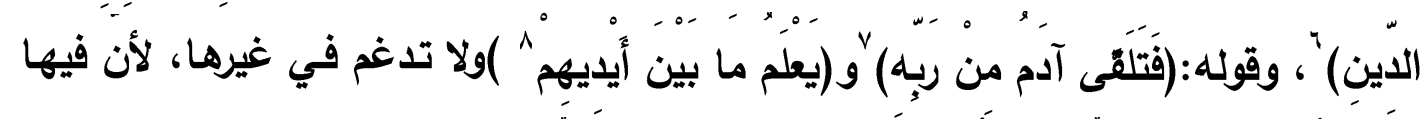

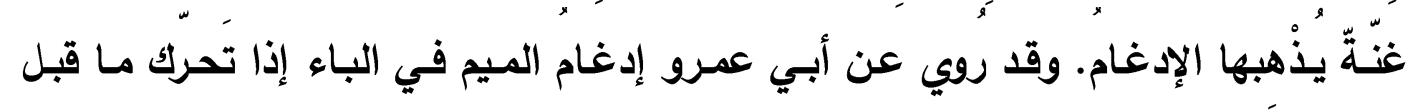

$$
\begin{aligned}
& \text { ') } \\
& \text { r الآية به } 10 \text { من سورة النساء. } \\
& \text { "الآلية به من سورة الأنعام. } \\
& \text { ؛ الآية • • من سورة النحل. }
\end{aligned}
$$

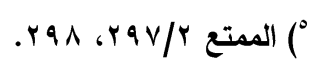

$$
\begin{aligned}
& \text { ) الفاتحة: r }
\end{aligned}
$$

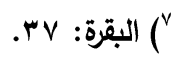

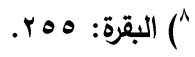




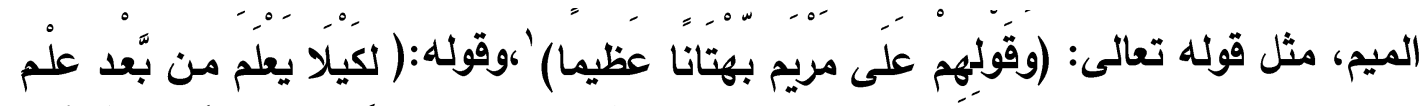

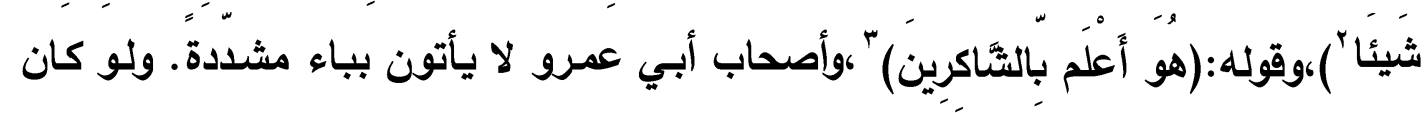

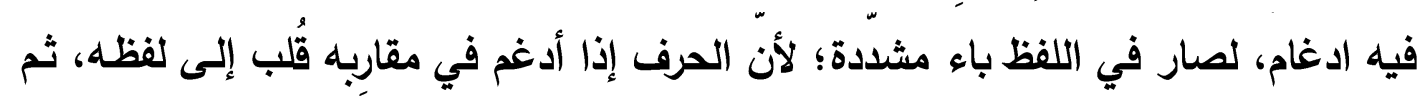

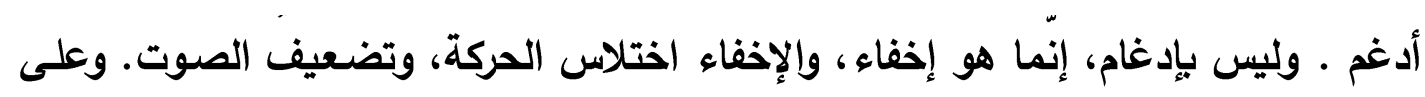

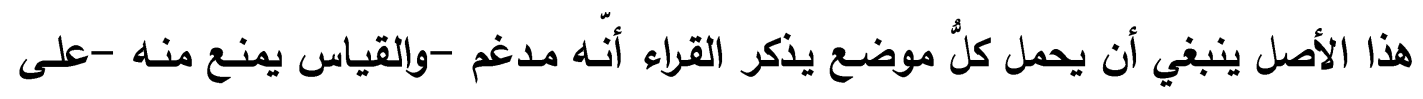

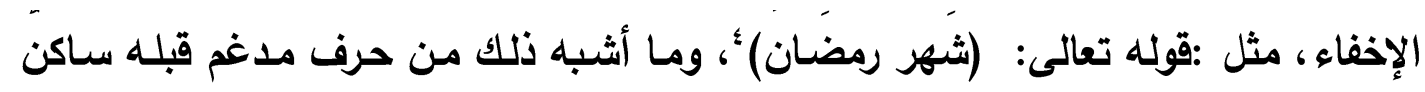

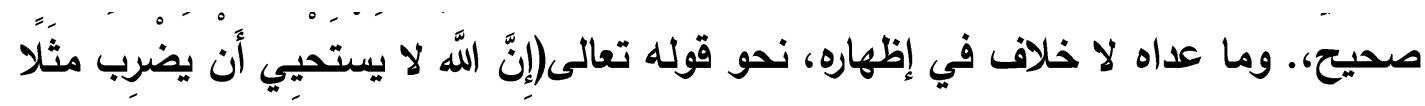

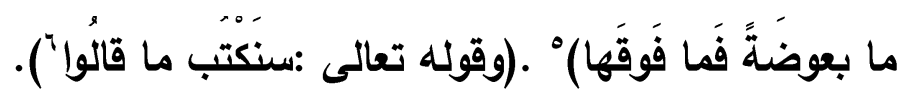
فالميم المتحركة إذا وقعت بعد حرف متحرك، ووقع بعد الميم الباء فإن الميم في هذه الحالة تخفى، أي تستتر مـع الغنة:فإن كان الحرف الذي قبل الميم ساكنًا فإنـه لا خلاف في إظهار الميم حينئذ، ومنه قوله تعالى:

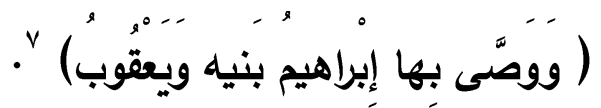

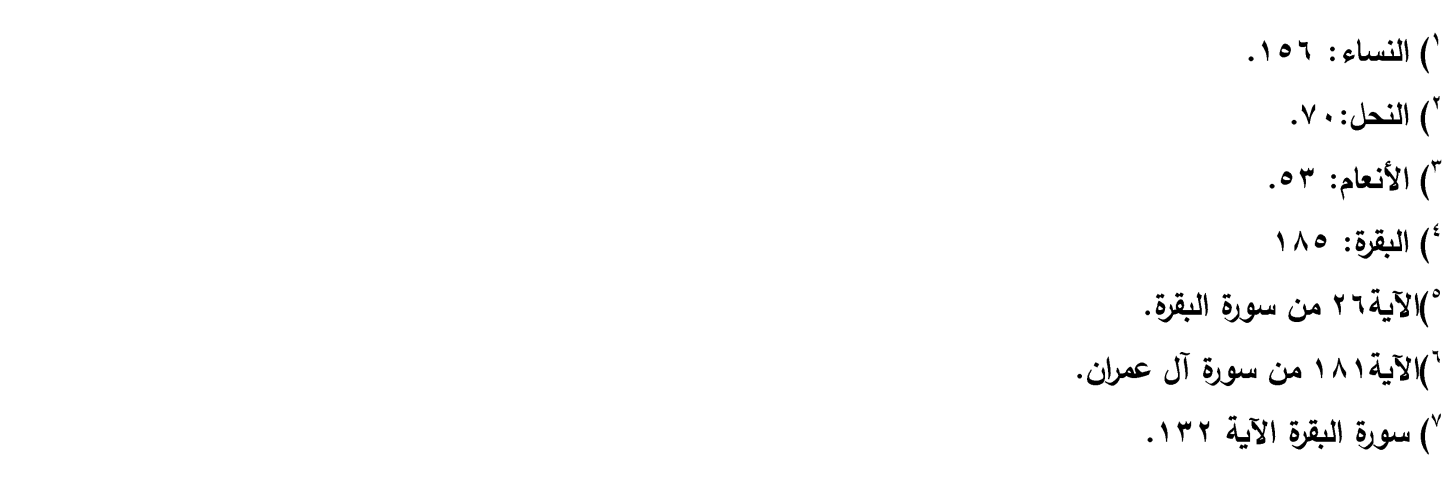

(حولية كلية الآداب- جامعة بني سويف عدد خاص - يناير (r.T) 


\section{ج - إدغام اللال في الضاد والصاد}

يقول أبو الحسن :"وعلى ذلك ينبفي أن تحمل قراءة أبي عمرو( من بعد صَّراء مسته)'، و( من بعد صَّعف) '، و( المهد صَّبَّاً) على أنه أخفى حركة الدال في جميع ذلك

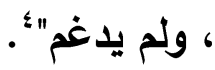

ويمكن القـول إن الضـاد لا تـدغم في شـيء مـن مقارباتها، وسـبب ذلـك أن فيها استطالة وإطباقًا واستعلاء، ولا يوجد في مقارباتها مثل هذه الصفات. وغير ذلك مـن

الأمثلة

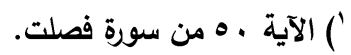
(الآية ؛ ه من سورة الروم.

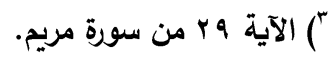

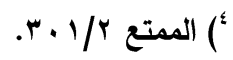
: - - إدغام أبي عمرو الثاء في الذاّل( والحرث دُلك) بإدغام الثاء في الذال وما قبلها ساكن صحيح، ولكن يتخرج على مثل مـا تقدم من الإخفاء. - إد غام أبي عمرو الجيم في التاء( ذي المعارج ثَّرج) ، وسيبويه بم يذكر إدغامها إلا في الثين خاصة، فينبغي أن يحمل ذلك

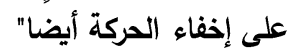
- إدغام أبي عمرو الحاء في العين من قولهم( فمن زحزح عَّن النار) في إحدى الروايتين. والصحيح أن إدغام الحاء في العين لم يثبت ، وإن جاء من ذلك ما يوهم أنه إدغام فإنه يحمل على الإخفاء".

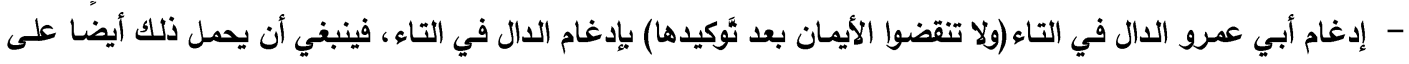
الإخفاء". - إدغام أبي عمرو السين في السين( الثمس سراجًا) بإدغام السين في السين ، و(لبعض شَّأنهم) بإدغام الضاد في السين،

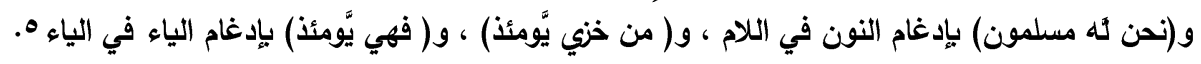




\section{د. حسن رمادي غانم نصر}

لذا يقال: الضاد أثرت في الدال تأثيرا رجعيًّا فحولتها إلى جنسها وأدغمت فيها، وذلك لأن الضـاد تفوق الدال في ملامسح القوة التي تتصف بها، واستطالت الضاد حتى وصلت بمخرج الدال، ومما زاد في قوة الضاد وقوعها متحركة في بداية مقطع، ووقوع الدال ساكنة في نهاية مقطع زاد من ضعفها .والبيان في مثل هذه التجاوزات عربي جيد لبعد

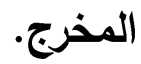

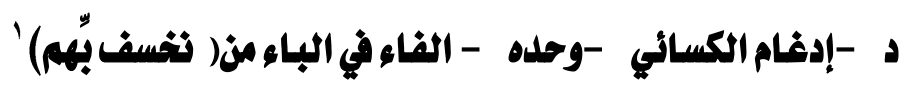

يقول أبو الحسن :"وقد تقدم أنها من الحروف التي لا تدغم في مقاربها، ولا يحفظ ذلك من كلامهم، وهو مـع ذلك ضعيف في القياس لما فيه من إذهاب التفشي الذي في

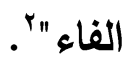

\section{ويمكن القول إن الفاء لا تدغم إلّا في مثلها؛ نحو قوله تعالى}

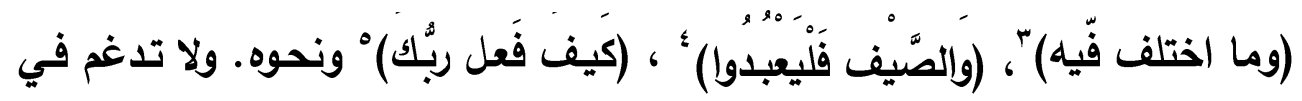

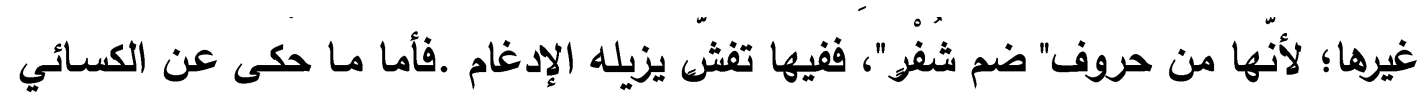

وجميع نلك ينبفي أن يحمل على الإخفاء لما في الإدغام من الجمع بين ساكنين، وليس الأول حرف مد ولين، وأيضًا فإن الضاد

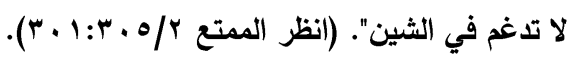

$$
\begin{aligned}
& \text { ') 'الآية 9 من سورة سبأ. }
\end{aligned}
$$

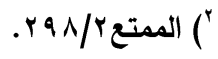

$$
\begin{aligned}
& \text { (') }
\end{aligned}
$$

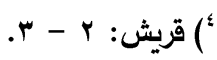

$$
\begin{aligned}
& \text { ") الفجر: با، والثيل: أ. }
\end{aligned}
$$

(حولية كلية الآداب- جامعة بني سويف عدد خاص - يناير (.r.Y) 


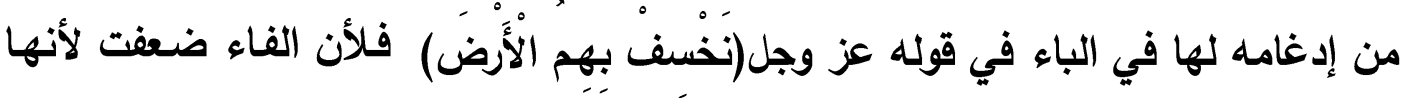
وقعت ساكنة في نهاية مقطع ولكن هذا الضعف لا يحتم الإدغام بدليل انفراد الكسائي به. أمسا إذا وقع صوت الفاء مجاورا لصوت الباء ، وكـان صوت الفـاء أولاً فالأفضل البيان ليقى كل صوت منهما محافظًا على الصفات المميزة لـه ، وذلك لأن صوت الفاء

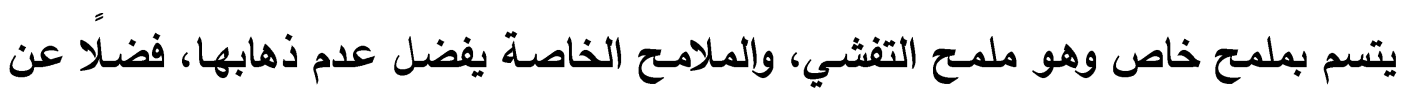
تباين صفات الصوتين، فالفاء متفش مهموس احتكاكي، وصوت الباء مجهور انفجاري.

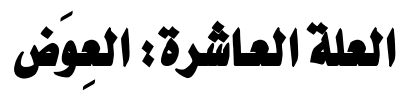

عوض الثيء لا يتواجد في حيز الوجود ميع الثيء المعوض منه لقيام العلاقة بينهما على مبذأ التعاقب، يقول الزجاجي(VTrTه) ':" العوض والمعوض لا يجتمعان".ومن المسائل التي علل بها ابن عصفور "العوض":

\section{1 - لزوم الإدفام فيما عينه ولامه ياء( في المثلين ) في المثرد}

وحذف ياء "تفعيل" وإلعوض عنها بالتاء، وجواز الإدعام والإظهار في الجمع

ألزم أبو الحسن الإدغام في نحو "تحية" ،حيث يقول:" ومن قال "حِي" أجراه مجرى "رضي" ، فكما تقول "رضُوا" تقول" حيوا" ...فإن كان بعدها تاء التأنيث فلا يخلو أن تلحق

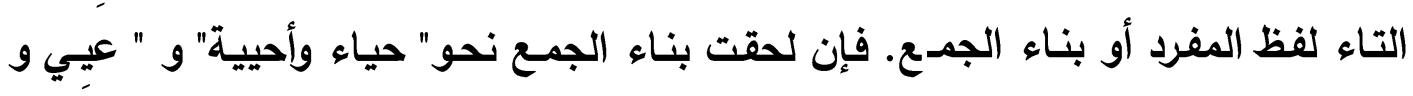




\section{د. حسن رمادي غانم نصر}

أعيية "جاز الإظهار و الإدغام نحو" أَحيَّة" و" أعيَّة"، فمن أدغم فلأن الحركة بناء، ولم

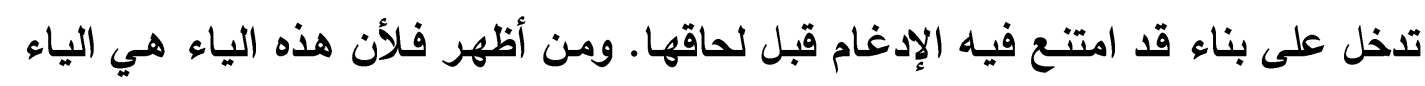
التي تسكن في " يعيا" و " يحيا". والإدغام في "أعيَّة" أقوى منه في "أَيَّة" لأن الياء في

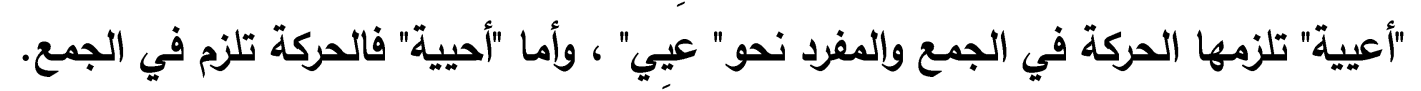
ويمكن القول:

1- - إن الياء لا تثبت في المفرد ، بل تقول "حياء" فتنقلب الياء همزة لتطرفها بعد

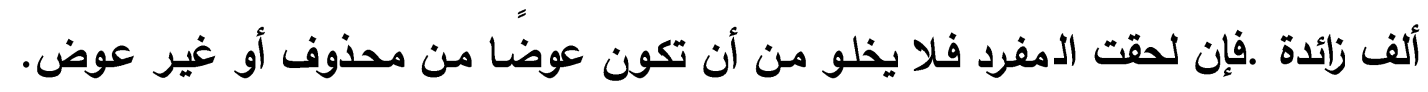

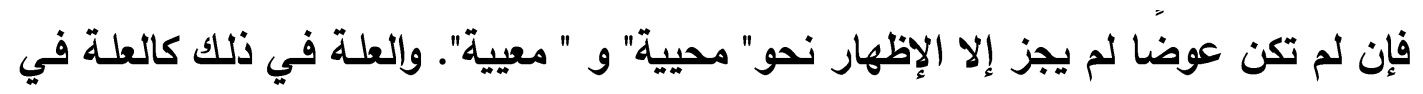
"محييات" و" محيينِ" من أن العلامة دخلت على بناء لا يجوز فيه الإدغام وهو" محي" و" و

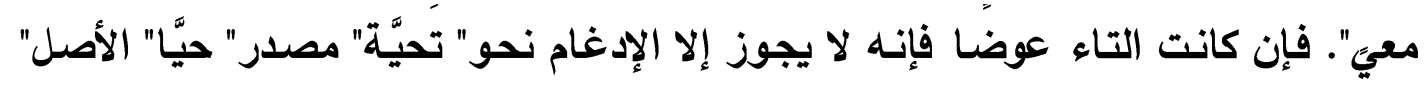
تحييا" فحذفت ياء "تفعيل" وعوضت التاء منها على حد " تكرمة" فصار "تحيية" فصارت هذه التاء لأجل العوضيَّة كأنها جزء من الكلمة فلزمت فصارت الحركة لازمة لذلك فلزم الإدغام"'

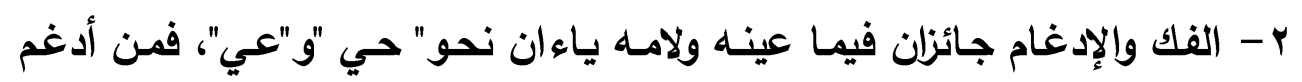

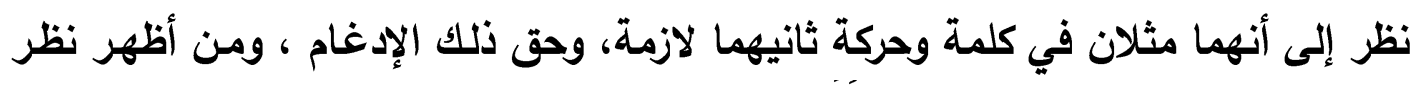

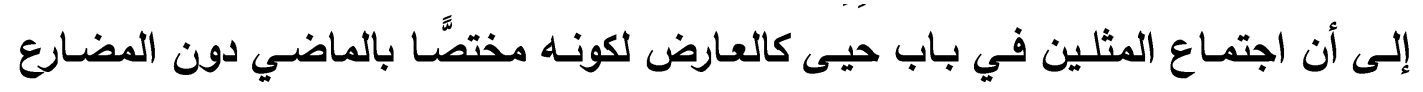
والأمر، والعارض ألاع يعت به غالباء.

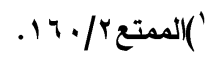

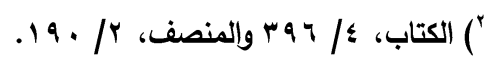

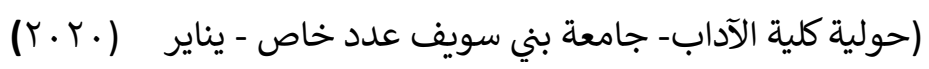




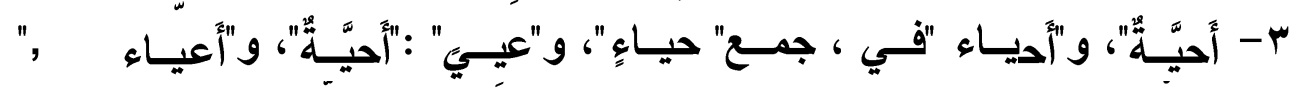

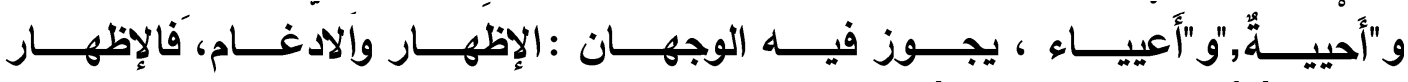

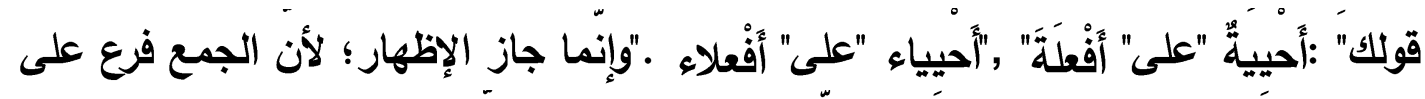

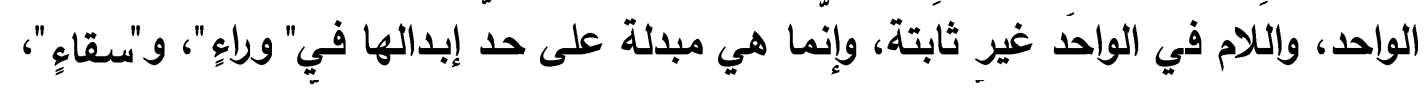

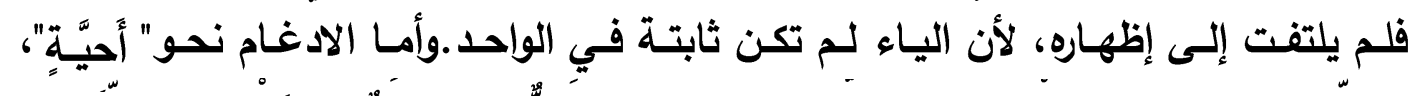

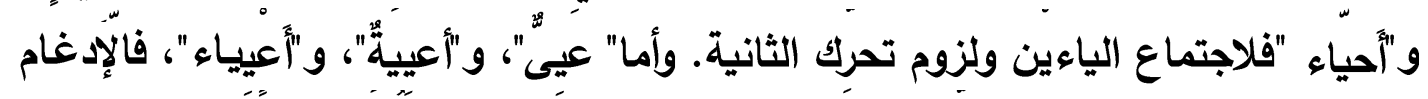

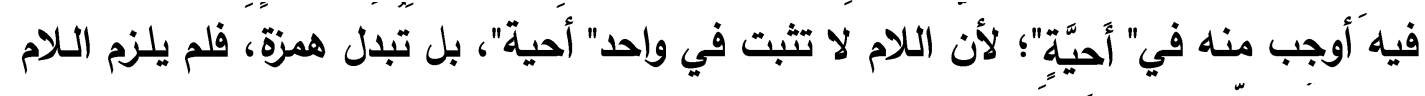

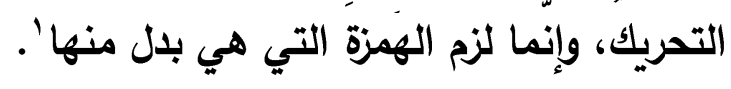

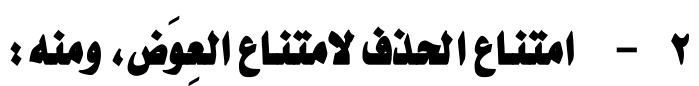

\section{عدم حذف الياء من الاسم المنقوص المعرفة}

يقول أبو الحسدن:" وممـا يـل على أن التنوين في "جوار" و" غواش" وأمثالهمـا

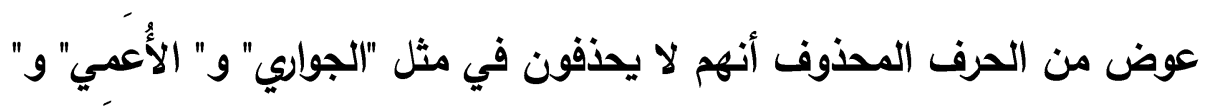
جواريك" و" أُعِيميكَ" لأنهم لو حذفوا لم يكن لهم سبيل إلى العوض لأن التنوين لا يمكن

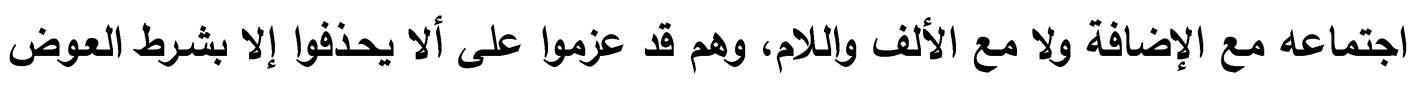
، فامتنع الحذف لذلك"'. ويمكن القول:

1- تثبت الياء في المنقوص المعرف وإلمضاف، لأنها إنما حُفتَ من المنَّر لأجل التنوين حََرا من التقاء الساكنْين، وقد زال المدذور بالإضافة أو التعريف. 
ץ- يجوز -على خلاف الأفصح- حذقها من المعرَف، بناء على جواز الوقف على

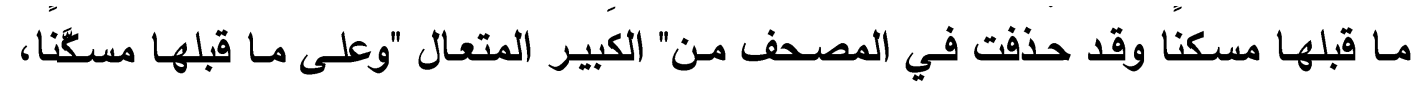
و"الدَّاع "و"الواد "و "يوم التَّاد"

ب- تحذف يـاء المنقوص إذا رفـع ونـون نحو :جـاء سـاع جديدّ، ولعبت نـوادٍ

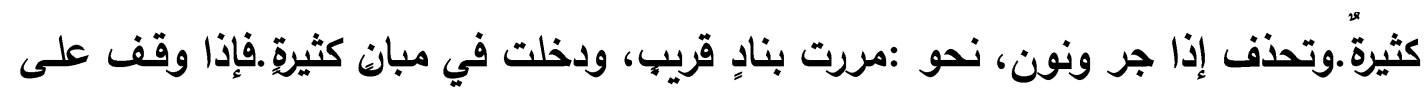

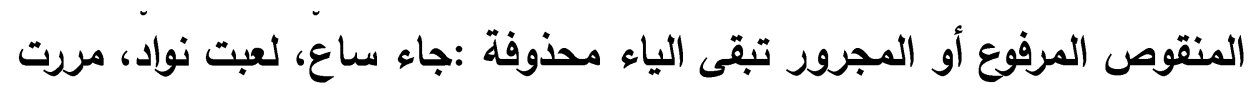
بناد، دخلت في نواد، ويجوز في لغة الوقف بإعادة الياء :جاء ساعي، ومررت بنادي. ب-سمع حذف الياء مـن دون تنوين للخول لام التعريف على الاسـم كمـا في قولـهـ

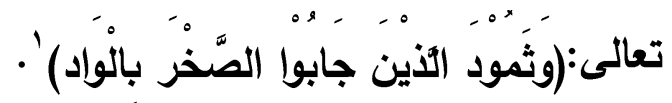

\section{الملة الحاديلة مشرة؛ الالهجة}

علة اختلاف اللفات(اللهجة) من العلل الصوتية التي علل بها أبو الحسن، ومن ذلك:

\section{1}

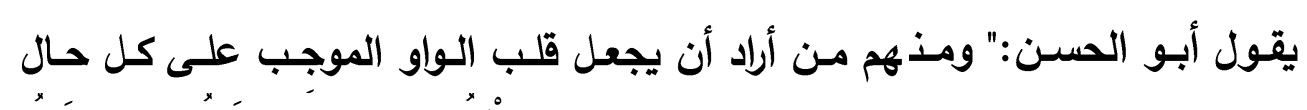

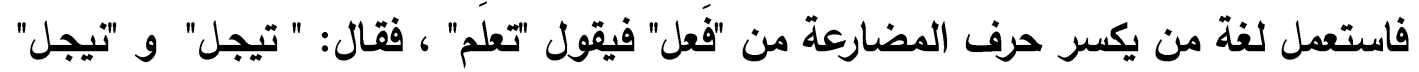


و" إيجل" و "يِيجل" فكسر حرف المضارعة إذا كانت ياء استثقالا للفتحة في الياء ، فجاءت الواو بعد كسرة فقلبت ياء.

فإن قيل : فإنهم لا يقولون "يعلَم" فيكسروا حرف المضارعة إذا كان ياء استثقاًاً

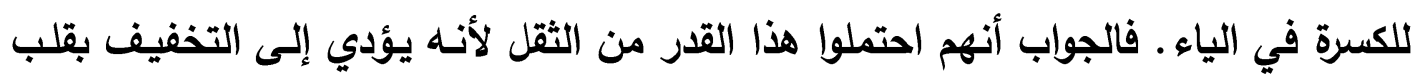

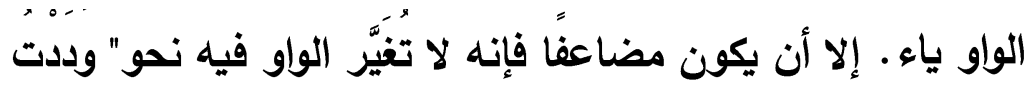

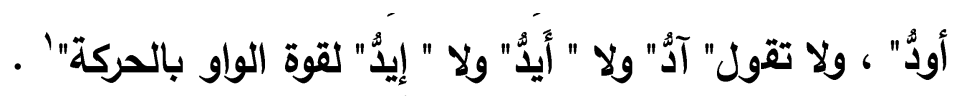

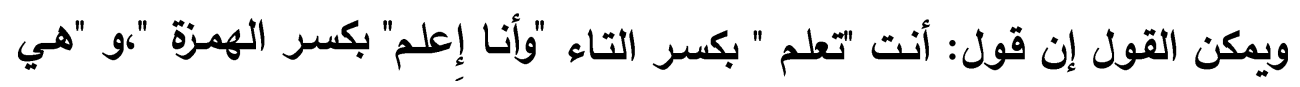

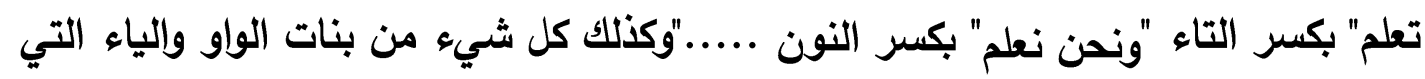

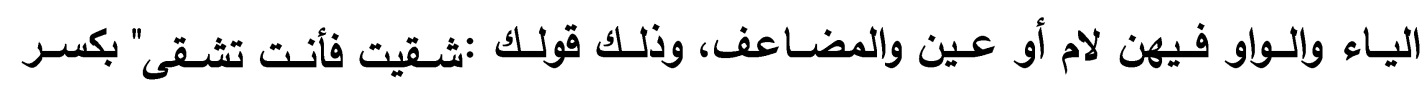

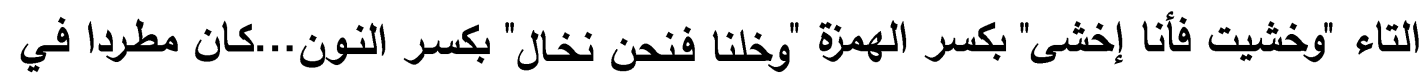

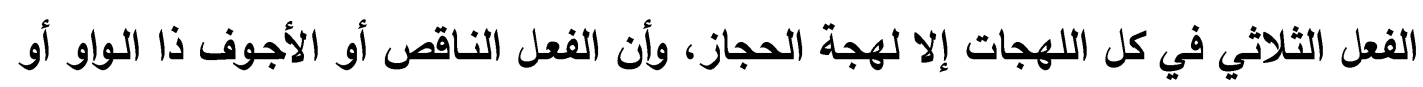

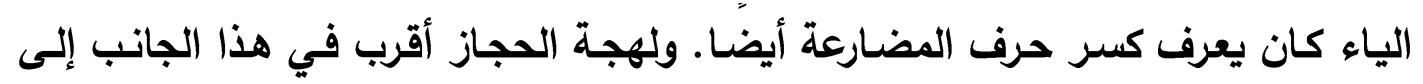

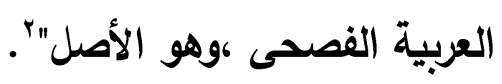

\section{r - بابلدال البيه من الياء المشددة في الوخف}

يتفق أبو الحسن مع سيبويه في إبدال الجيم من الياء المثددة، فيقول:" وأما الجيم

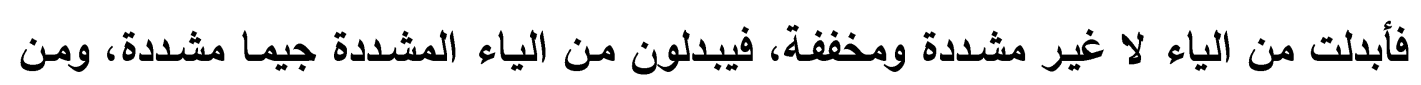

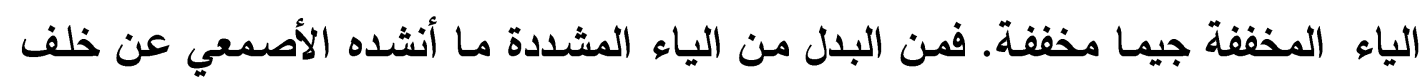




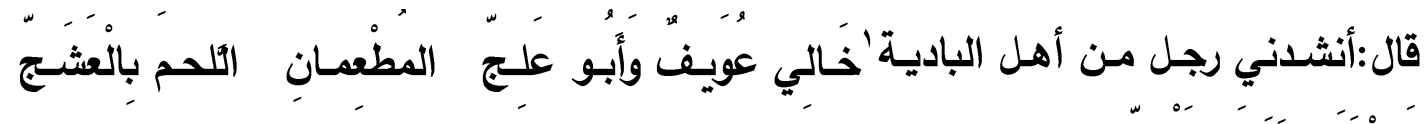
وبِالْذاة فَلق البرنج

يريد" و أبو علي" و "بالعشي" و "فلق البرني ".ومنه أيضًا ما حكاه أبو عمرو بن العلاء

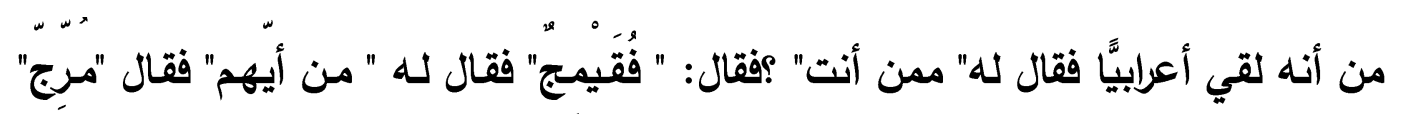

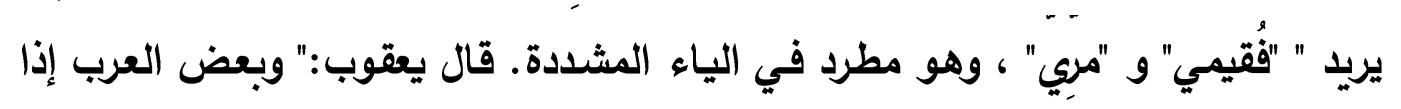

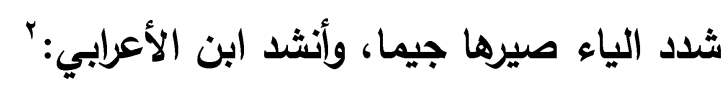

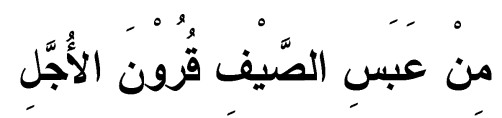
كَأَنَّ فِي أَذْنَابِهنَّ الثُُوَّل

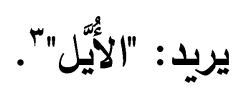

ويمكن القول: إن الجيم تبدل من الياء المثددة في الوقف، وهي لغة قوم من بني سعد من تميخ؛ لاشتراكهما في المخرج لكونهما من وسط اللسان، واشتراكهما في الجهر، و

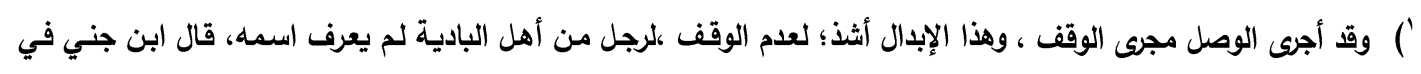

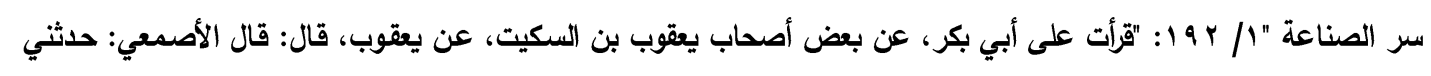

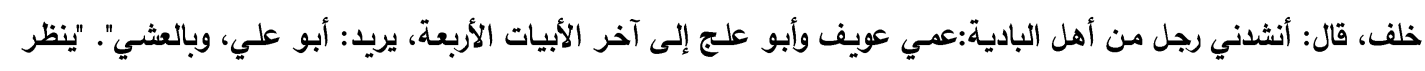

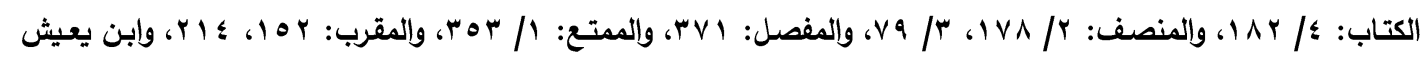

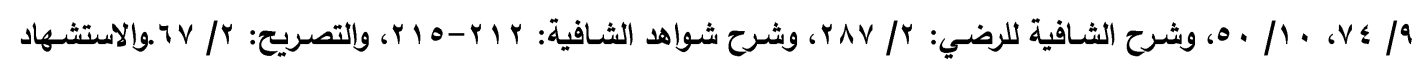

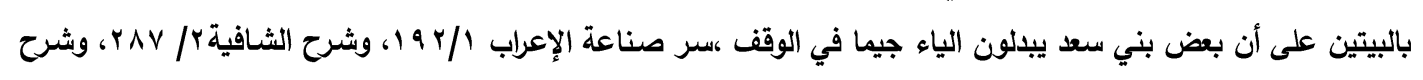

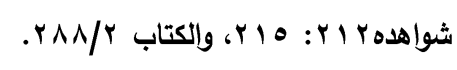

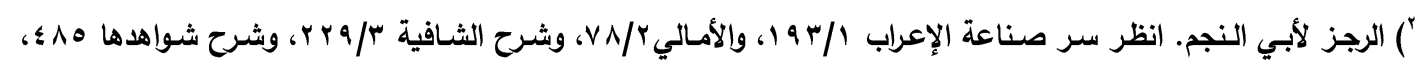

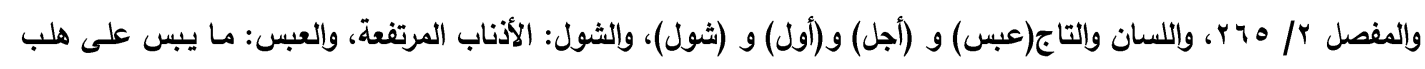
الأنب من البول والبعر، والأيل: ذكر الأوعال.

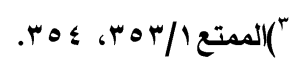

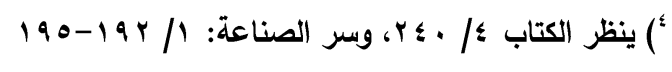

(حولية كلية الآداب- جامعة بني سويف عدد خاص - يناير (·. ) 


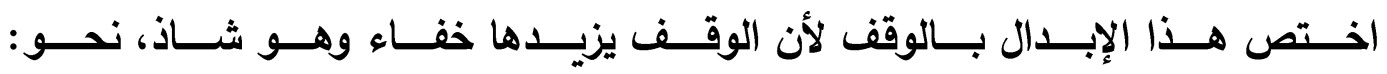

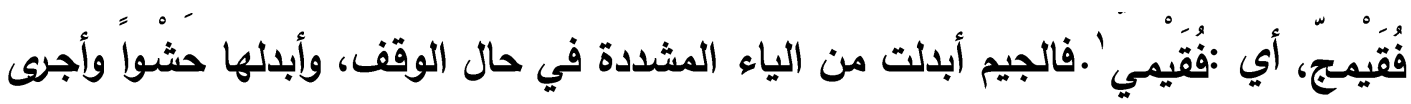
الوصل مجزى الوقف متوهما أنها ملفوظ بها ياء.

ويمكن تفسير هذا البدل بأن الجيم صوت مركب كما وصفه المحدثون وهو صوت مجهور أيضًا، وإلياء هنا إمـا نصف حركة كما في(علي) أو حركة طويلة كما في (بي) وهي في كلتا الحالتين مجهورة، ولكن كلا الصوتين يصدران من المخرج الغاري، فبينهما تقارب في المخرج، علاوة على أن الياء وقعت ساكنة في نهاية مقطع فضعفت بالموقعية، فضلًا على أن الياء وقعت في النهاية، والناطق يريـ لأن يقفل المقطع بصوت يظهر في حالة الوقف فأبدل منها أقرب الأصوات إليها وهو صوت الجيم، وفي (علج) أبدلت الجيم من الياء بوصفها نصف حركة ، أما إبدال الجيم من الياء المشددة في غير الوقف فتفسيره الوحيد القرب المخرجي، علاوة على التتابع بين الحركات وأنصاف الحركات وهو تتابع غير مرغوب فيه.

\section{ب - إبلدال الجيم مز الياء المخفمة2}

يقول أبو الحسن ': "ومن إبدال الجيم من الياء المخففة مـا أنشده أبو عمرو بن

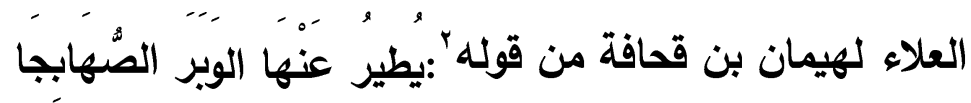

') وذلك فيما حكي عن أبي عمرو بن العلاء من أنه لقي أعرابيا فقال له: ممن أنت؟ فقال: فقيمج. فقال له: من أيهج؟ فقال:

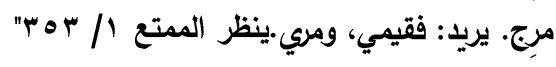




\section{د. حسن رمادي غانم نصر}

يزيد "الصُّهابي" من الصُّبهة، وأصله" الصهابي" فحذف إحدى الياءين، ومن

ذلك ما انثده الفراء من قول الثاعرّّا

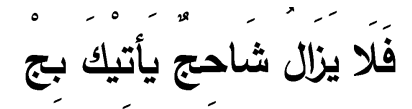

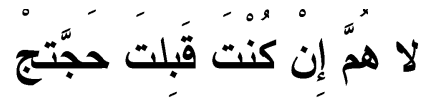

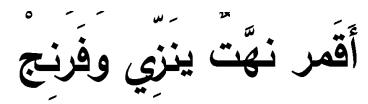

يربد: "حجَّتي" و "يأتيك بي" و "ينَزِي وفِرتي"

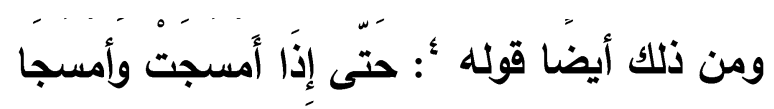

يريد:" أمسيت وأمسيا" فأبدل من الياء جيما ولم يبدلها ألفًا.

ويمكن القول إن هذا البدل غير مطرد في الياء الخفيفة، بل يوقف في ذلك عند

السماع.

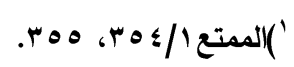

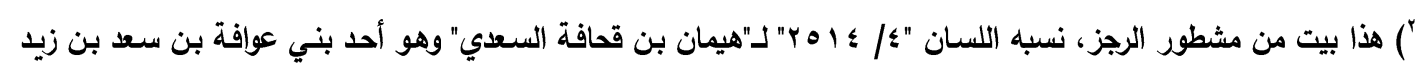

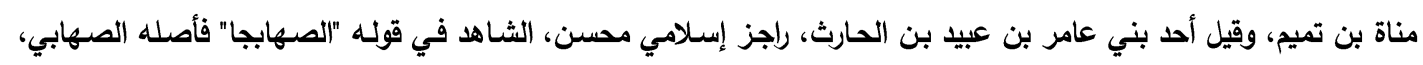

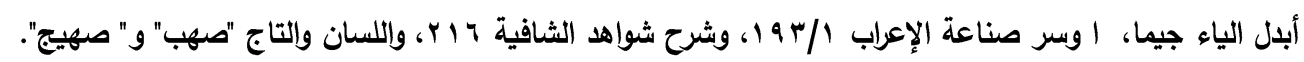

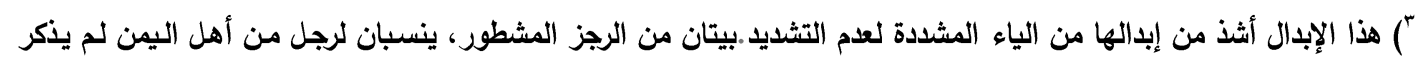

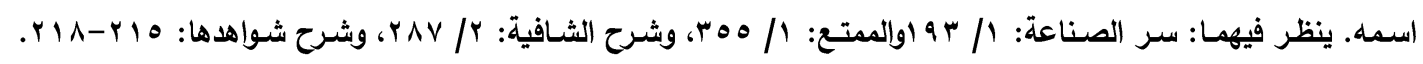

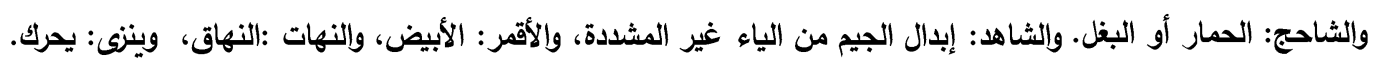

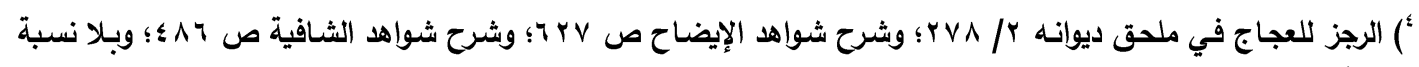

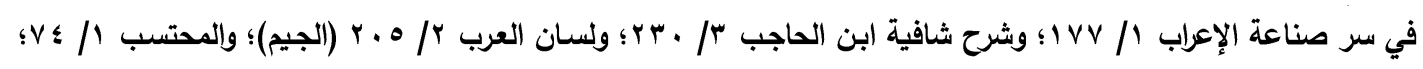

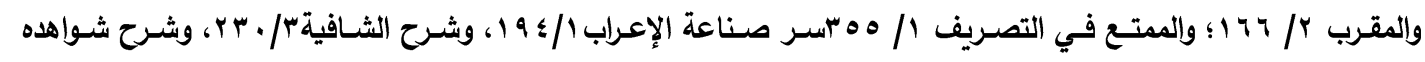

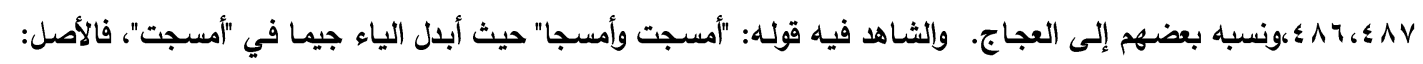

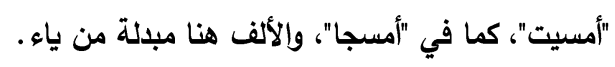

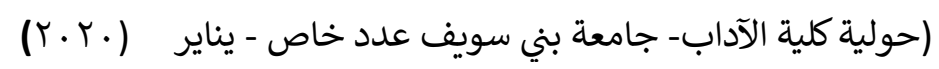




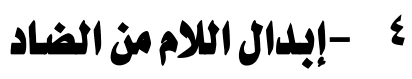

تبدل الـلام مـن الضـاد ، يقول أبو الحسـن:" وأمـا الـلام فأُبـلت مـن الضــاد فـي

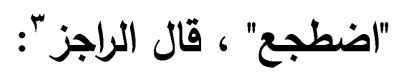

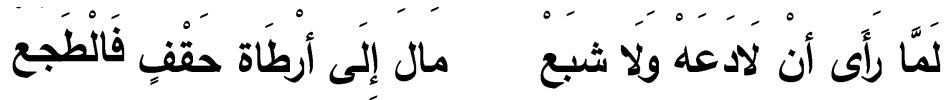

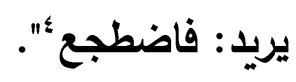

ويمكن القول إن من الإبدال الثائع إبدال اللام من النون ومن الضاد، ومن إبدال

الجيم من الياء، الثـائع في ذلك مـا اطرد أو كثر في بعض اللغات كالعجعجة في لغنة قضاعة، والعنعنة كقولهم :ظنت عنك ذاهب"، أي أنك، والكثشثة في لغة تميم، كقولهم في خطاب المؤنث: ما الذي جاء بشِ "يريدون بك، وقراءة بعضهم" :قَّد جعل ربُشِ تَحتَشِ

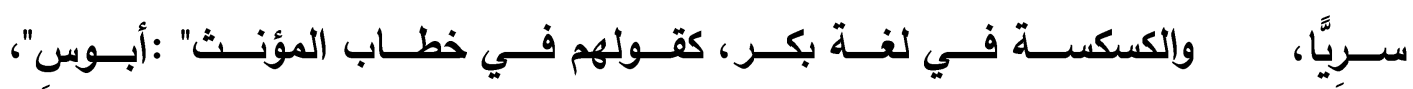
و"أمس "يريدون" أبوك "و"أمك."

$$
\text { وتفسير ذلك : ض+ط }
$$

') ' قال البغادي:" وذهب ابن عصفور في كتاب الضرائر إلى أن إبدال الياء الخفيفة جيما خاص بالشعر، ولم أره لغيره (انظر

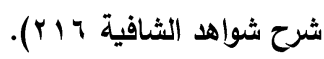

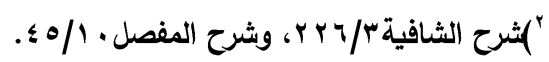

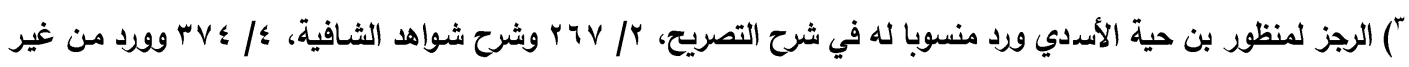

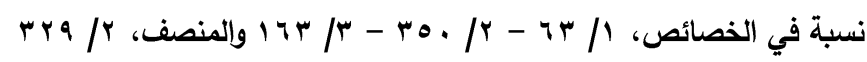

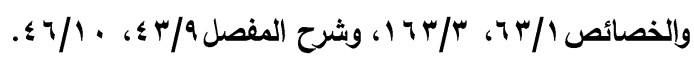
.

183

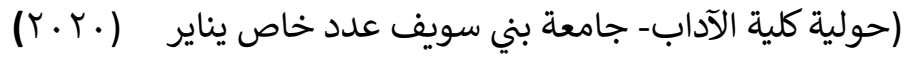




\section{د. حسن رمادي غانم نصر}

بأنه اجتمع صوت الضاد والطاء وهما صوتان يجمع بينهما التفخيم ، فضلًا عن وقوع صوت الصاد ساكنا في نهاية مقطع نحو اضطجع، مما أدى إلى إضعافه بالسكون، وقد حصل بين هذين الصـوتين المتمـاثلين تخـالف صـتي تمثل في استبدال صوت الـلام بصوت الضـاد : الطجع، وذلك لأن صوت اللام أكثر وضوحا في السمع من صوت الضاد.

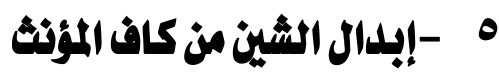

نص أبو الحسن على إبدال الثين من كاف المؤنث:" وأمسا الثين فأبدلت من كاف

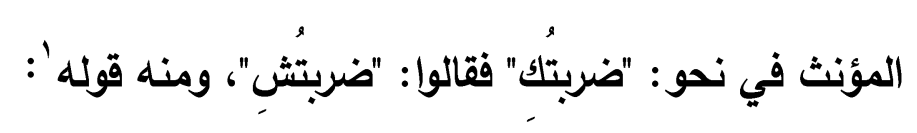

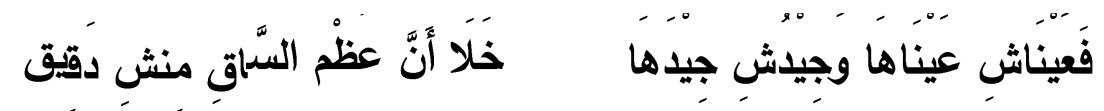

ويمكن القول إنه كَانَ الْقَاس فِي الثَين المبلدة من كَاف المخاطبة أَن تحذف في

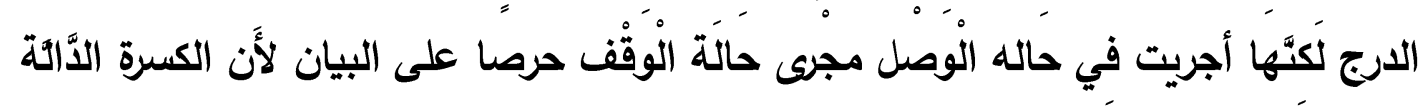

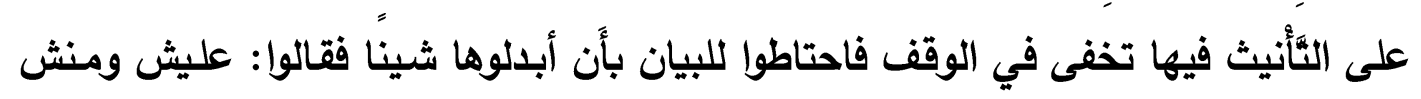
ومررت بش. وتحذف في الوصل.ومنهم من يجر ي الوصل مجرى الوقف فيبدل منه أَيضًا؟.

') من الطويل لمجنون ليلى، الشاهد في البيت:عيناش، جيدش، منش" فقد قلب الكاف شينا، والأصل "عيناك، جيدك، منك" انظر

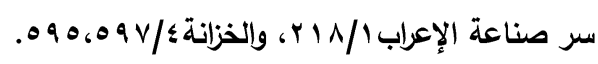

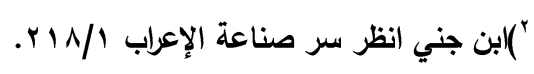

(حولية كلية الآداب- جامعة بني سويف عدد خاص - يناير (·. ) 
ويمكن تعليل هذا البلل صوتيًّا على أنه عادة لهجية كانت سائدة بين بعض القبائل العربية، وقد أصبحت تميز بين المذكر والمؤنث

\section{4 - إبلدال العين من الهمزة( العنعنة )}

بدل العين من الهمزة في بعض البيئات اللهجية ، وهي ما أطلق عليها القدماء عنعنة تميه، يقول أبو الحسن:" وأما العين فأبدلت من همزة "أن" فقالوا "عن" ـ قال الثاعر ':

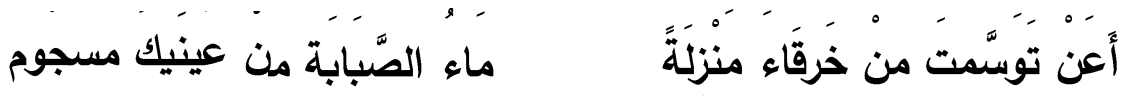

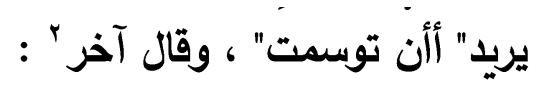

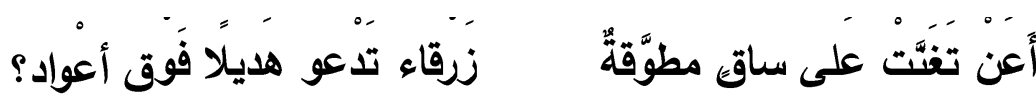

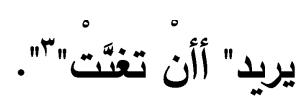

ويمكن القول إنه : يريد :إن تَوسَّمت، ويروى :إن، وهذه لغة من يقيم العين مقام

الألف والألف مقام العين لقرب مخرجهما، وذلك في الفتح، فإذا كسروا رجعوا إلى الألف، ويعود العبب في ذلك إلى :التقارب في المخرج، علاوة على أن صوت العين أكثر وضوحا في السمع من الهمزة ، والوجه فيه أنَّ العين تقرب من مخرج الهمزة وهي أبين من الهمزة

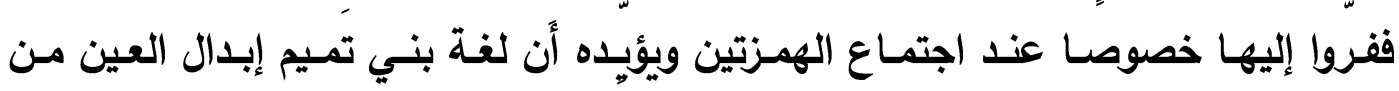

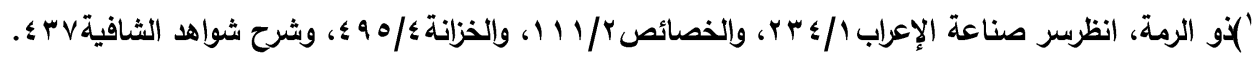

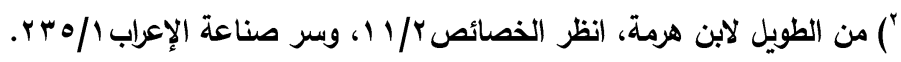
(1) 


\section{د. حسن رمادي غانم نصر}

الهمزة' . والوجه فيه أنَّ الهمزة وإلعين متجاورتان في المخرج ،فمن ذلك قولهم في عباب

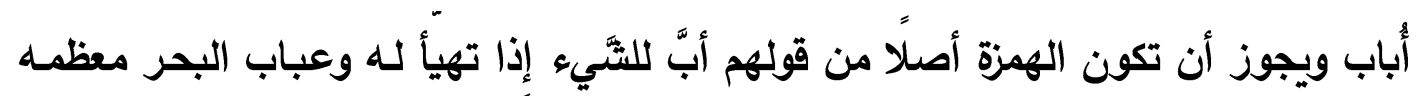

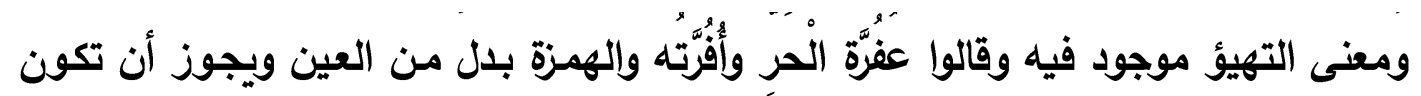

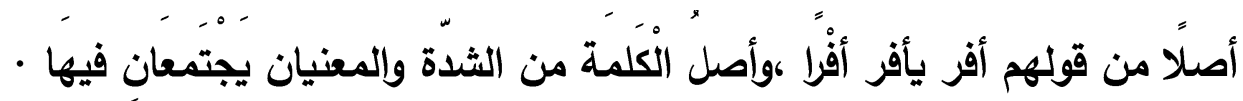
وقد أبدلت من همزة "أنَّ" فقال "يعجبني غنّ عبدالله قائم"، يريدون: "أن عبدالله قائم"

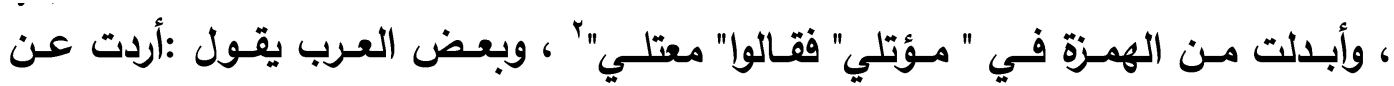

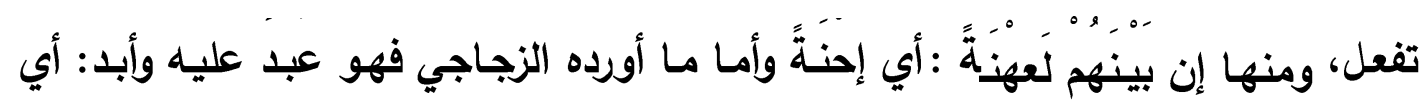

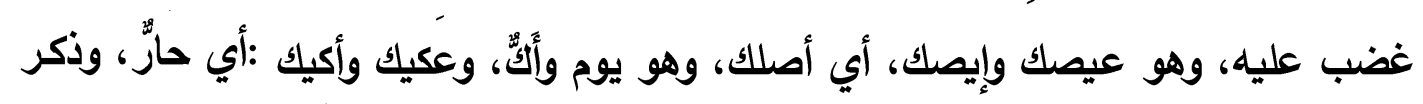
محمد ابن يحيى العنبري أن رجلاً من فصحاء ربيعة أخبره أنه سمع كثيراً من أهل مكة :

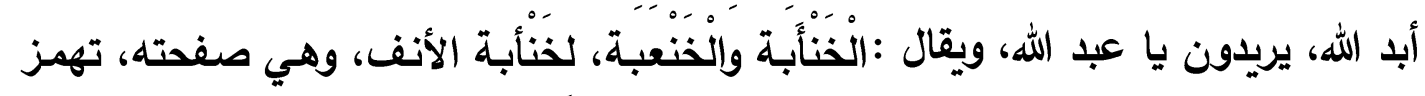

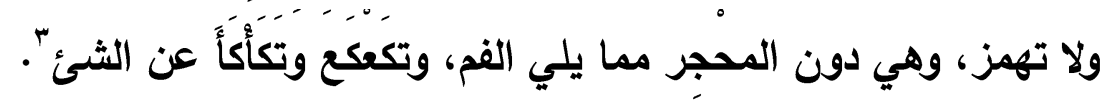
إبدال الكاف من تاء الضمير المخاطب

أبدلت الكاف في اللهجات العربية من تاء الضمير المخاطب، يقول أبو الحسن:" وأبدلت الكاف من تاء ضمير المخاطب في "فَعَتْت" فقالوا "فَعْلْك" ، وأنثثد

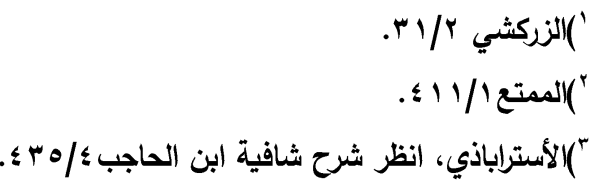


سحيم قصيدة فقال " أحسنْكَ والله" يريد "أحسنتَ والله" ، وأنشد أبوالحسن لبعضهم ':

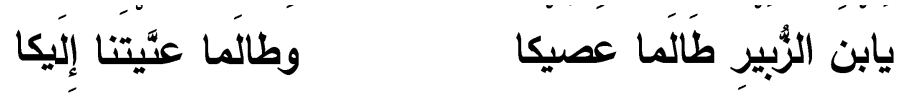

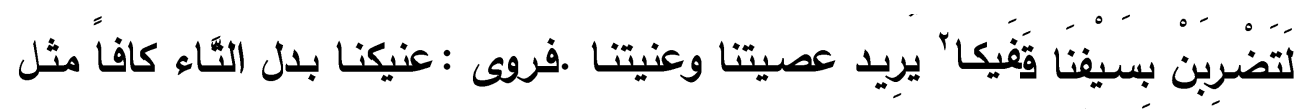

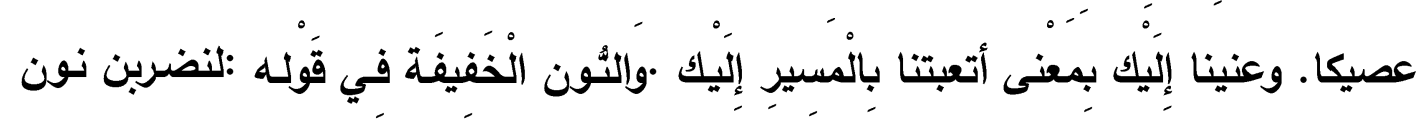
التوكيد

ويمكن القول إنـهـ نيابـة ضـمير غير موضـوع للرفع عن موضوع لـه ،لكن وضـع ضمير النصب مرفوع ضمير الرفع، غير صحيح، بل الذي ذكره اين عصفور أن هذا من إبدال تاء الضمير كافًا، وهو من شاذ البدل، فليس من وضع ضمير النصب موضع ضمير الرفع .والذي يدل على أنه من باب البدل تسكين آخر الفعل له في قولهم :عصيك. فالكاف بدل من التاء بـلاً تصريفيًا لا من باب إنابة ضمير عن ضمير .ومن الملاحظ في هذه الأحرف أنهـا منتشـرة في بيئـات لهجيـة ، عـلاوة على العلاقة الصـوتية بـين الصـوتين المبلين إما في الملامتح أو في المخرج.

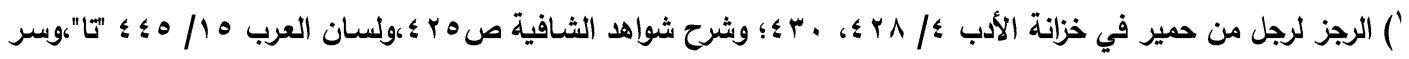

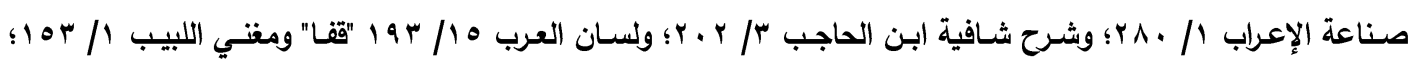

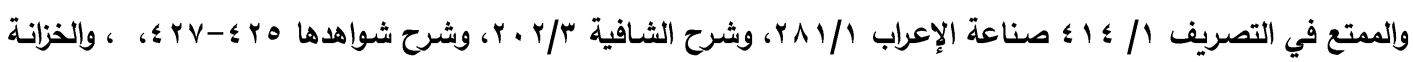
rov/r rه ،وقفيكا أصله: قفاكا، قلبت فيه الألف ياء ، وروي "عنّيكنا" بدل من "عنَّيتنا".

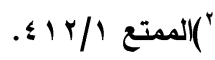

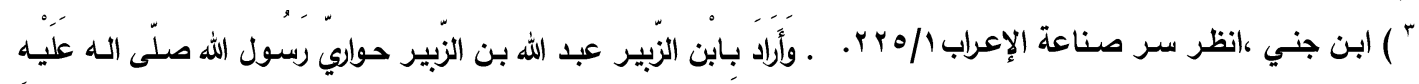

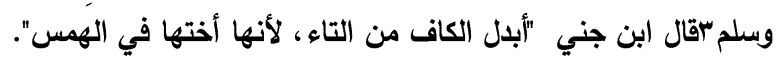




\title{
- V - Vصحيع اسم المفمول من اليائي
}

أجـاز ابـن عصفور الإتمـام في" مفعول" مـن ذوات اليـاء وهي لغـة بنـي تمسيم.

قال' :وكأنها تفاحة مطيوبةٌ

\begin{abstract}
وقال علقمة': حتى تذكر بيضاتٍ وهيَّجه يوم زادٍ عليه الريح مغيوم

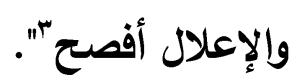

ويمكن القول إن(مفعول) من الثلاثي يحذف منه الواو أو العين-بحسب اختلاف

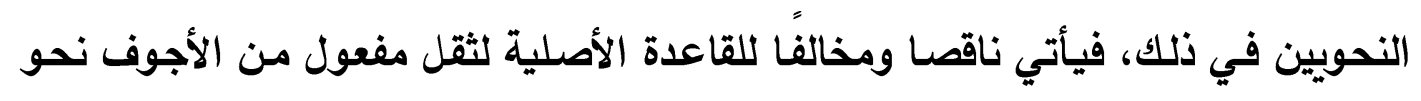

مقوول و مصوون و مبيوع و مخيوط، إلا أن هناك من يعامل المعتل معاملة الصحيح ،

') انصف بيت من الكامل لم يعثر على تمامه، ولم يعرف قائله، غير أنه شاعر من بني تميم يصف الخمر، والضمير في كأنها

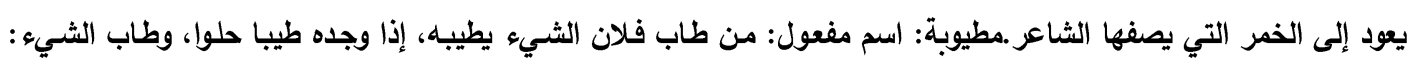

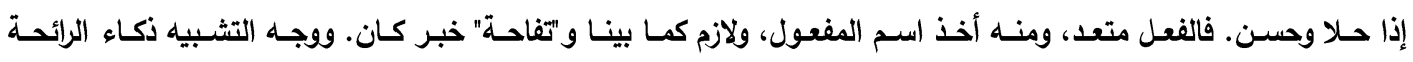

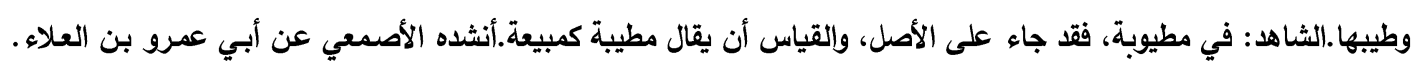

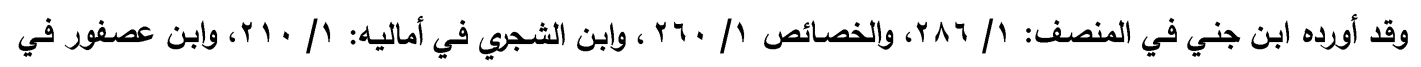

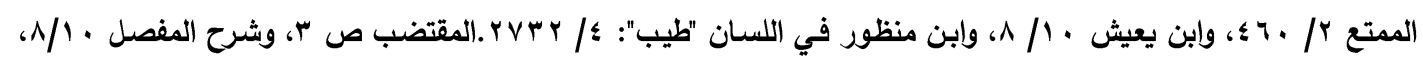

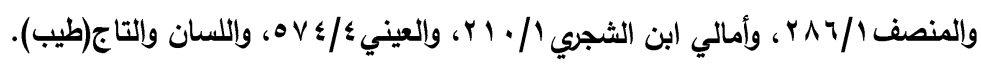

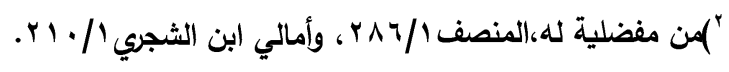
. 
فجاء به على الإتمام إخضاعا للقاعدة الأصلية حيث الإتمام أي رده إلى مـا كان ينبغي

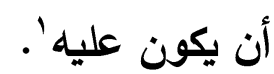

وكثر تصـيح اسـم المفعول في المعتل الياء حتى صـار قياسـا وهو لغـة بني تميم، نحو :مبييوع، ومخيوط، ومكيول، ومزيوت ومطيوب، ومغيومّ ،فبنو تميم تصحح اليائي، وربما صحح بعض العرب شيئًا من ذوات الواو، سمع ثوب مصوون؛ ، وفرس مقوود ، ويمكن القول إن سـبب الإتمـام هنـا سـكون مـا قبل الياء أو الـواو فجرت لذلك مجرى

الصحيح.

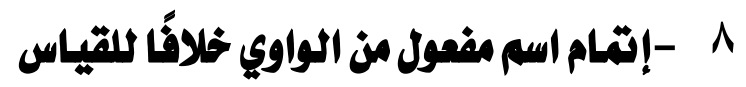

يقصر ابن عصفور الإتمام في اسم المفعول الثثلاثي الأجوف الواوي على السماع، وينقد من أجاز القياس في إتمامه، حيث ينكر الاحتجاج بالثاذ، فيقول: " ولا يجوز الإتمام في ذوات الواو إلا فيما سمع، والذي سمع من ذلك ْ" مسك

')وزن (مقول) (مفعل) ، ووزن( مبيع)(مفعل) عند الخليل وسيبوية، أما عند الأخفش فوزن(مقول)(مفُول) ووزن (مبيح): (مفَيل)

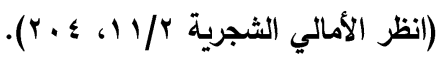

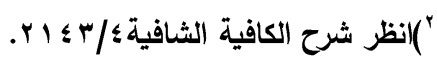

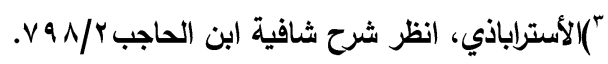
") ولا يقاس على ذلك ،وندر تصحيح الواوي العين؛ فيق ال: مصوون. واشتهر تصحيح بائي العين وهي لغة تميم؛ فيقولون: مبيوع ومخيوط.

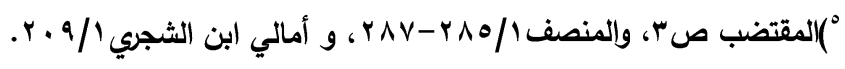




\section{د. حسن رمادي غانم نصر}

مدووف"، قـال الراجز ': والمسك في عنبره المدووف، والأثـهـ "مدوف" ، وقالوا" رجل

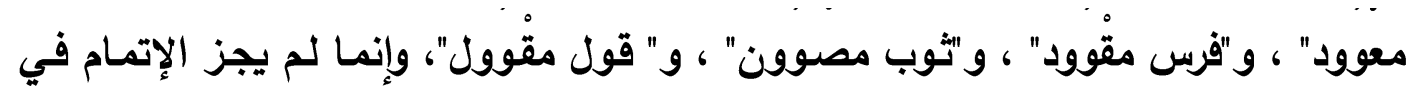

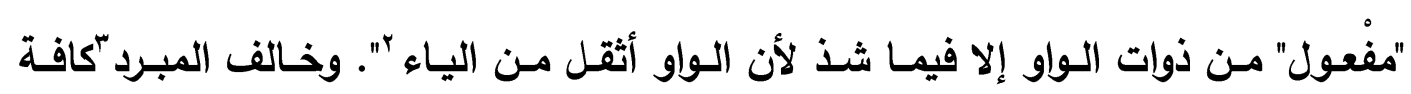
النحويين فأجاز الإتمام في ذوات الواو قياسا على ما ورد منه، وقال: ليس بأثقل من" سرت

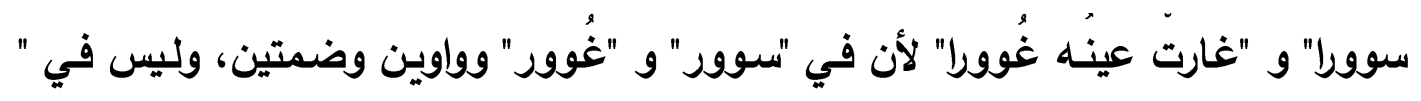
معوود" مع الواوين إلا ضمة واحدة ".وهذا الذي ذهب إليه باطل لأن ما ورد من ذوات الواو من القلة بحيث لا يقاس عليه.وأما احتجاجه ب "سوور" و "عوور" فباطل لأن مثل "سوور" شاذ، ولو لم يسمع لما قيل.

والضرورة دعت إلى ذلك في مثل "سوور" لأنهم لو أعلوا فأسكنوا الواو الأولى

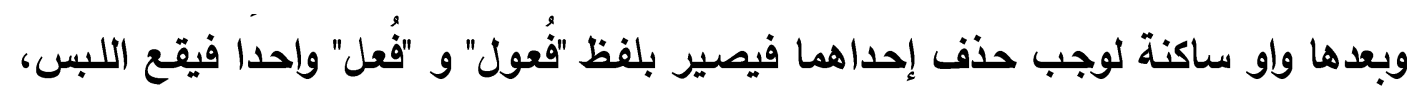

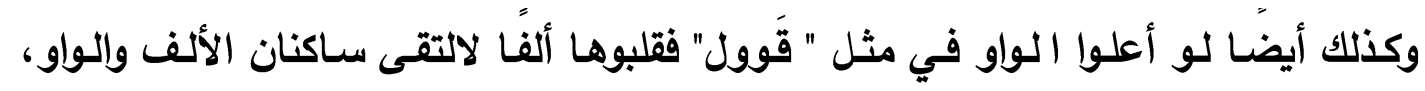
فيجب حذف أحد الساكنين فيصير "فَعول" و "فَعل" في اللفظ واحدا فيقع اللبس لأن المصدر

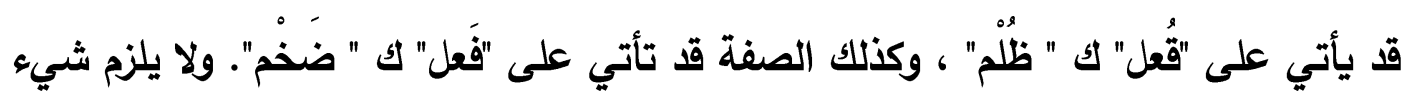

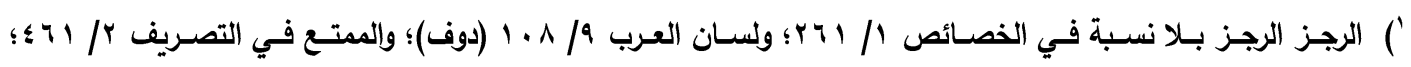

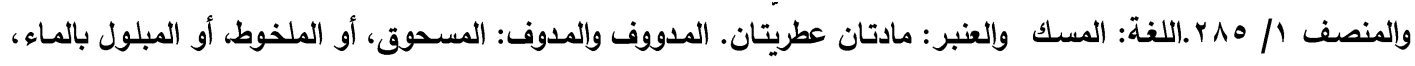

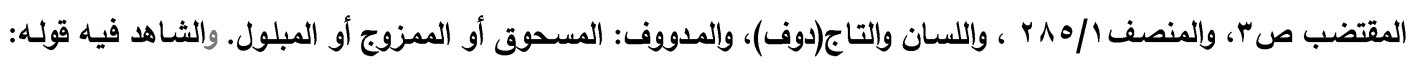

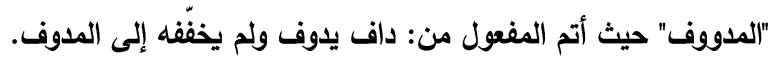

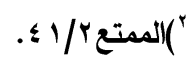

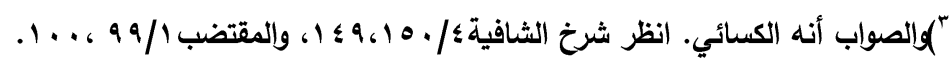

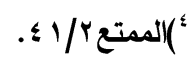


من ذلك في إعلال " مفعول" لأن اسم المفعول لا يأتي أبدا من الفعل الثلاثي إلا على وزن

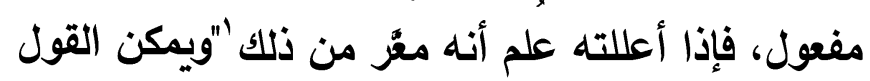

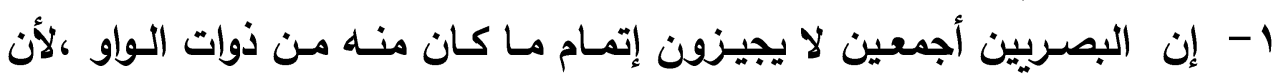

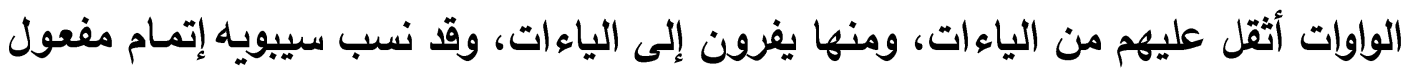

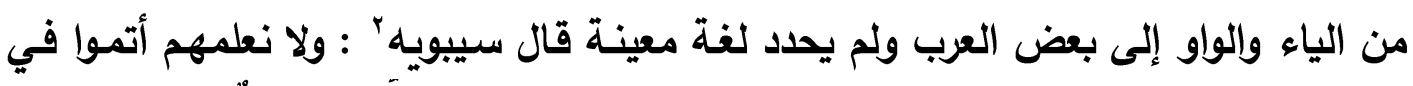

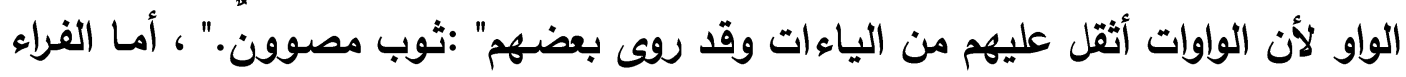

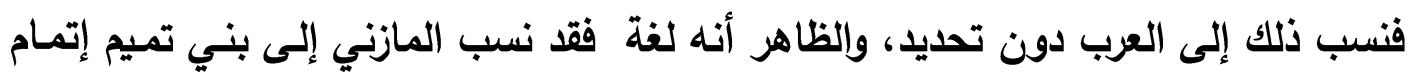

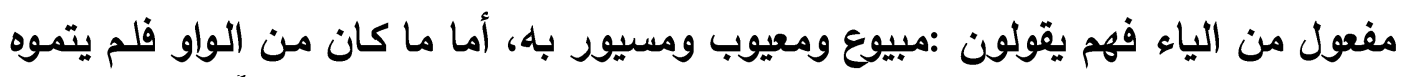

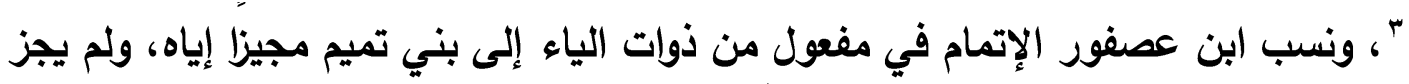
الإتمام في ذوات الواو غلا ما ورد مسموعا ولم يعزه إلى أحل.

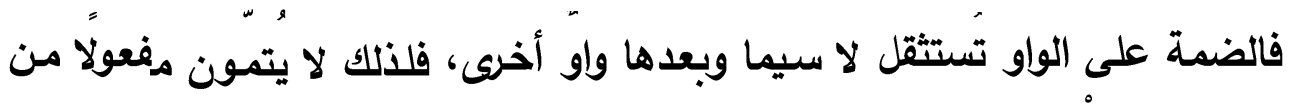

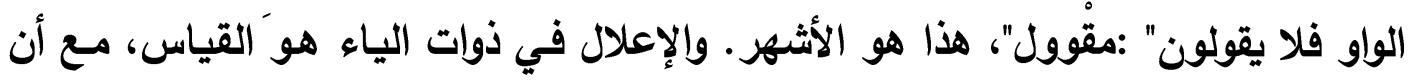

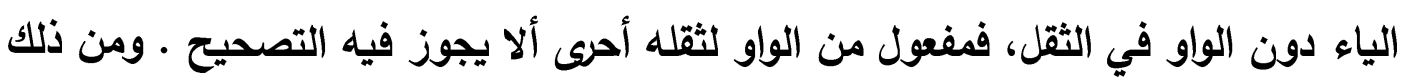
أيضا قولهم :فرس مقوود وقول مقوول، ورجل معوود.

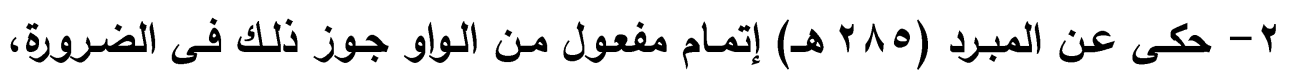

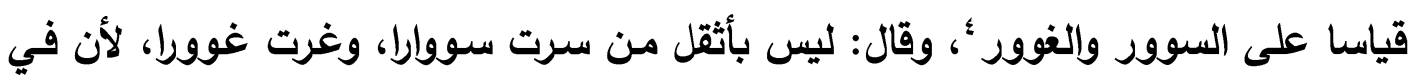

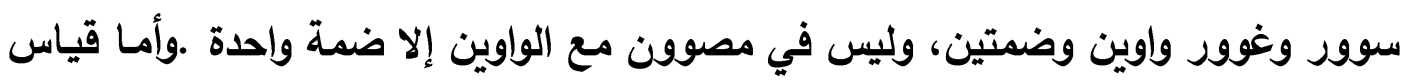

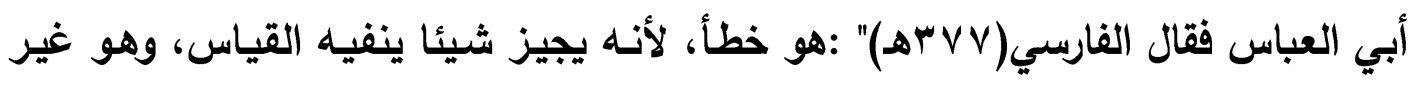

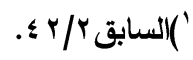

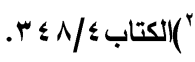

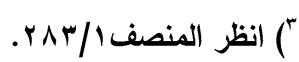

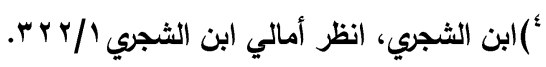




\section{د. حسن رمادي غانم نصر}

مسموع، فأما سرت سوورا فلو لم يسمع لما قيل، وإن فلو أعلوا في سوور لأسكنوا الواو

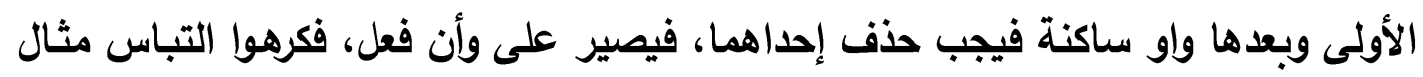

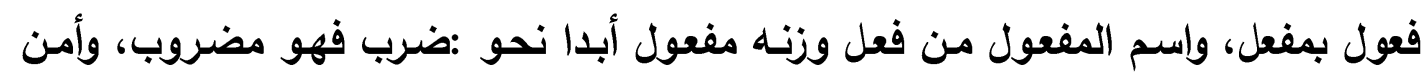

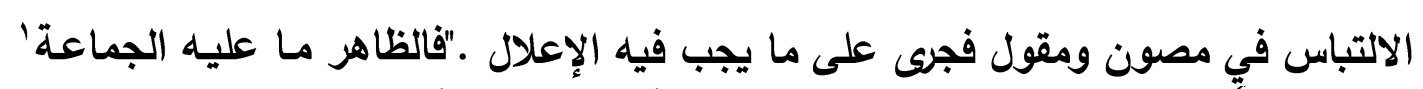

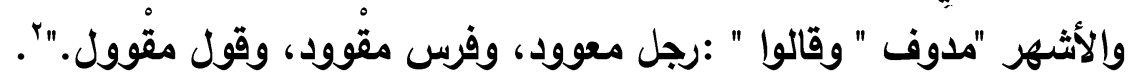

\section{الملة الثانية مشرة: استصحاب الهال}

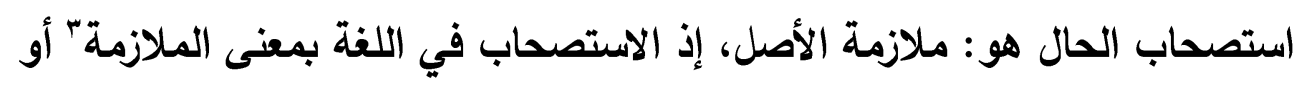

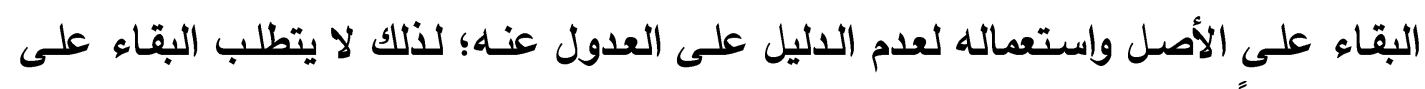

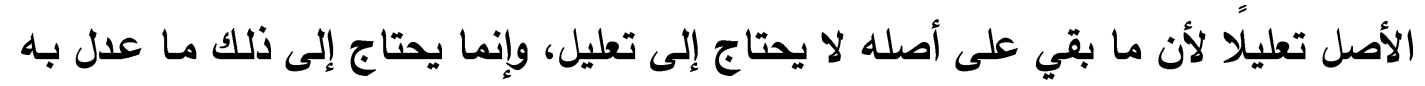

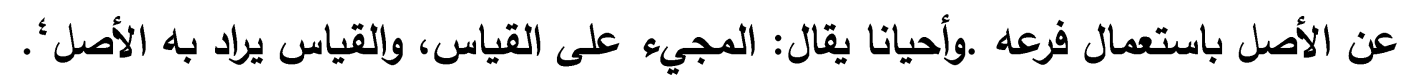

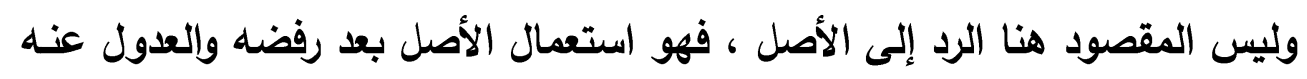

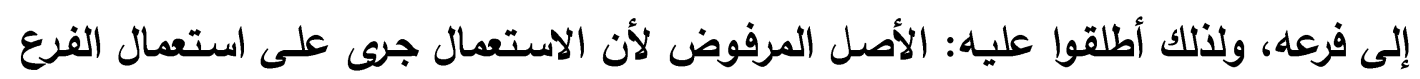

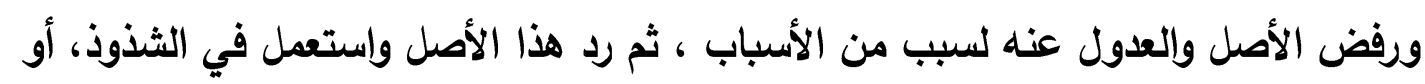
الضرورة الثعرية، ووصف بالقلة أو الندرة.

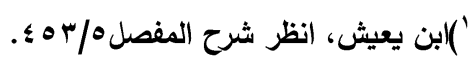

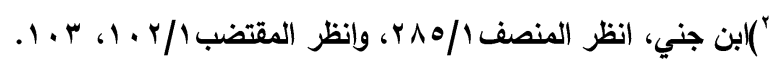

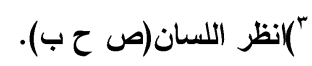

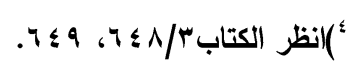

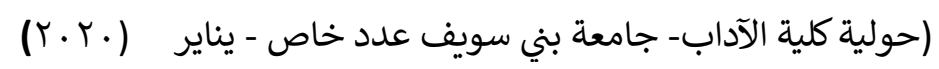


فالاستصـحاب - وهو استعمال الأصل والبقـاء عليه وهو كثير في كـلام العرب، فكثيرا ما يقولون: "لأنهم يردونه إلى الأصل '" ، ووضع سيبويه بابا هو( باب ما ترده علامة

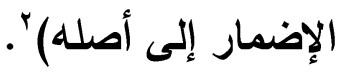

وذهب كثير من الصرفيين إلى أن قاعدة:" قد يستعمل الفرع وإن لم يستعمل الأصل"

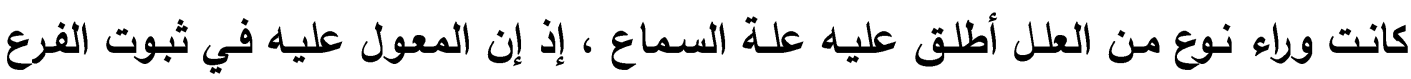
دون ثبوت الأصل هو ما سمع عن العرب ، وما نقل عنهم في هذا الثأن، والعرب كثيرا مـا تستعمل الفرع وتهمـل الأصول.وعلة الأصل هو مـا يسمى "الطرد" إذ الغاية الكبرى اطراد

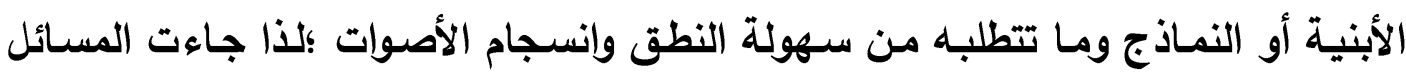
التي علل بها ابن عصفور استنادا إلى الأصل على النحو التالي:

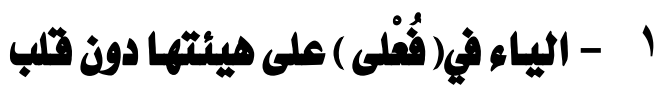

$$
\text { في الصفة دون الاسم }
$$

ذكر أبو الحسن اعتلال الكلام وصحة العين حتى لا يؤدي إعلالها إلى إعلال بعد إعلال وحذف، وعدَّ قلب الواو ياء لغير موجب ، فقال لهذا السبب: " ولولا ورود السماع لما قيل" ،حيث يقول: "وأمـا "ريَّا" التي يراد بها الرائحة فصفة من من معنى "رويت" وكان الأصل

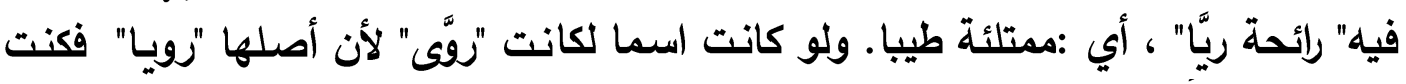

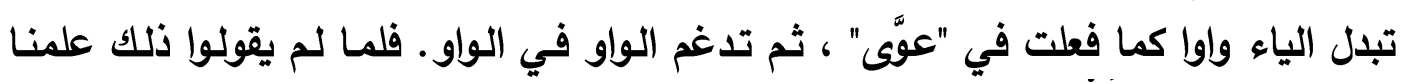

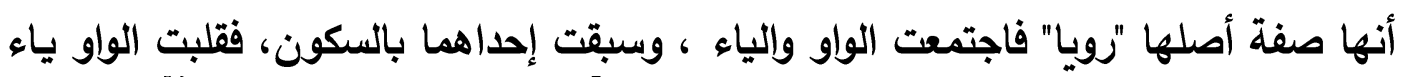

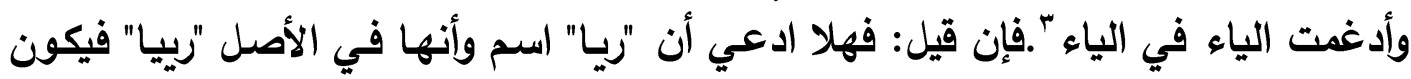

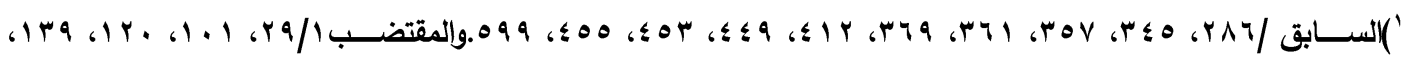

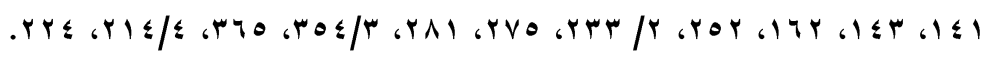

rV

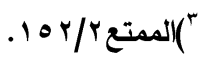




\section{د. حسن رمادي غانم نصر}

من باب ما عينه ولامه ياء، ثم قلبت اللام واوا فصار "ريوى" ، ثم اجتمع ياء وواو وسبقت

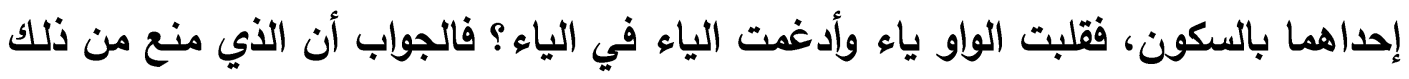
أنـه لا يحفظ مـن كلامهم تركيب "ر ي ي" ، ومـن كلامهم تركيب" ر و ي ي" نحو "رويـ". والسبب في أن اعتلت اللام في هذا الباب' وصحت العين أنك لو أعللتهما جميعا لأدى ذلك

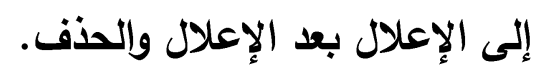

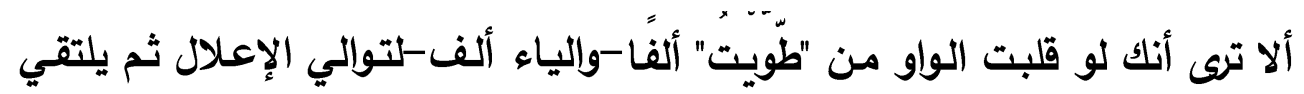

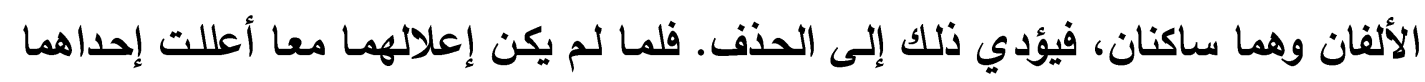

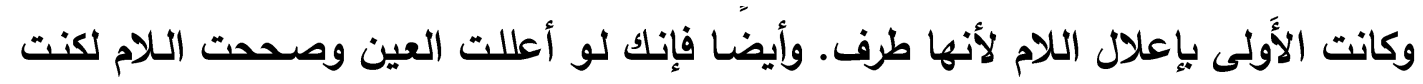

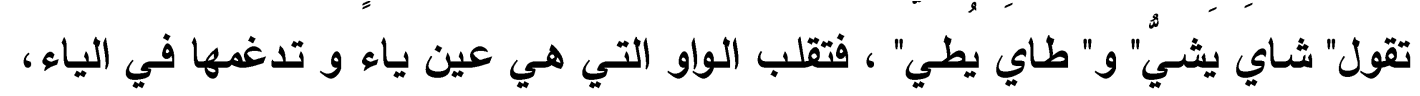

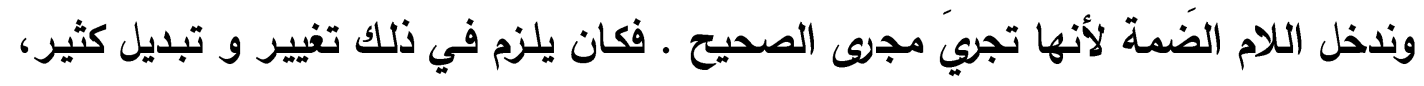

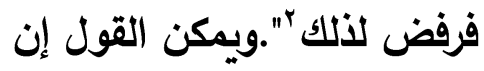

ا- قلب الواو ياء إذا كانت الواو لامـا ل "فُعَّى" اسما وليس صففة، نحو "اللدنيا،

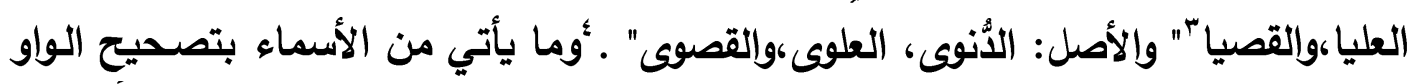

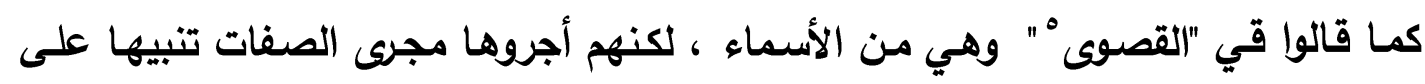
الأصل.

$$
\begin{aligned}
& \text { ')يريد : باب طوى و شوى. }
\end{aligned}
$$

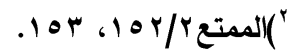

$$
\begin{aligned}
& \text { ") }
\end{aligned}
$$

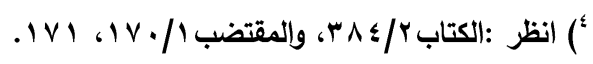

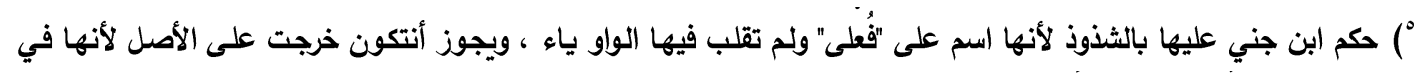

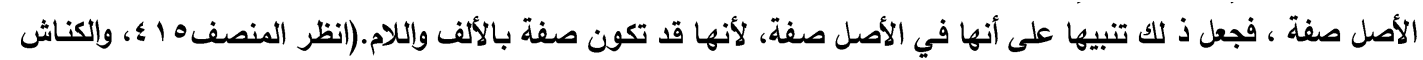




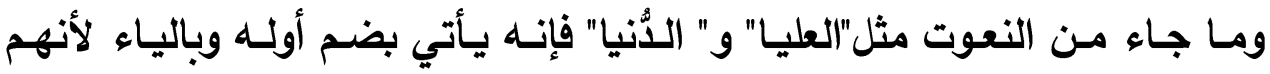
يستثقلون الواو مـع ضمة أولـه، فليس فيـه اختلاف، إلا أن أهل الحجـاز قالوا: القصوى،

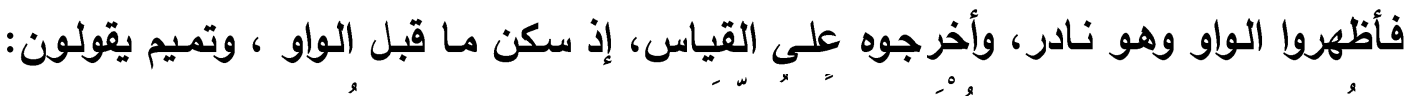

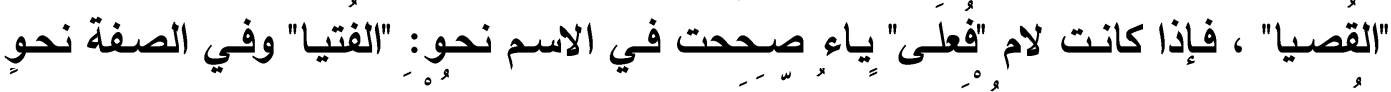
"القصيا" ووإذا كانت لام "فعلى" واوا صححت في الأسم نحو "حزوى"، وتعل الواو فتقلب ياء

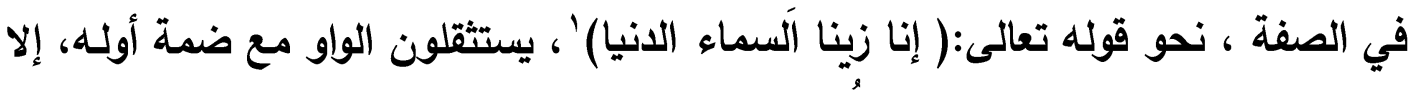
أن أهل الحجاز أظهروا الواو في "القصوى" جيء به على الأصل، وبنو تميم قالوا "القصيا" على القياس.

r - فعلوا ذلك تفرقة بين الاسم والصفة. وقلبوا الياء واوا في الاسم دون الصفة

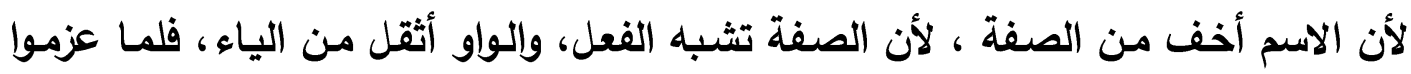
على إبدال الياء وإو جعلوا ذلك في الاسم لخفته ، فكان عندهم من أجل ذلك الك أحمل للثقل. وهو مع ذلك غير قياسي لأنه قلب لغير موجب، ولولا ورود السماع بذلك لما قيل'، وامتناع

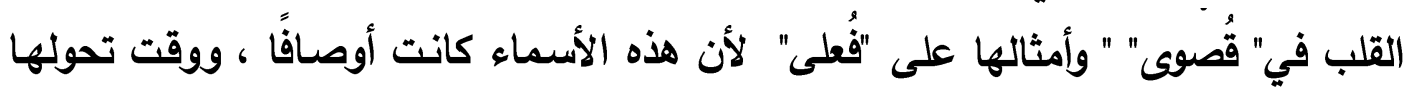

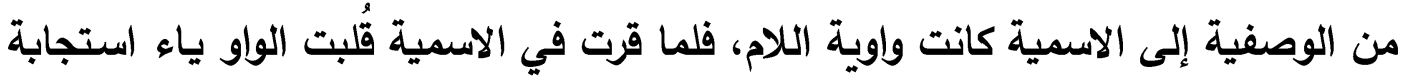
لما أملاه عليها وضعها اللغوي الجديد. r- ومن قلب هنا فلاعتبار التخفيف، ومن لا يقلب فلاعتبار اللبس إذ تلتبس فيما

ء - مَا حدث ل"فُعلى" من تغيير نتاج أسباب صوتية وصرفية، فإن كان نعتَا أبدلت

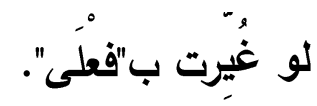

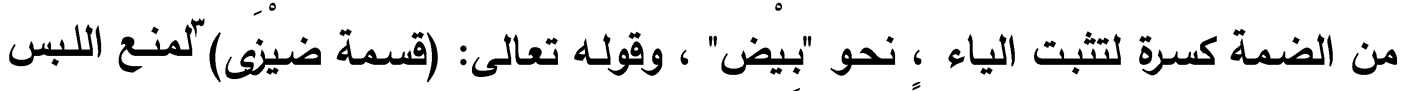

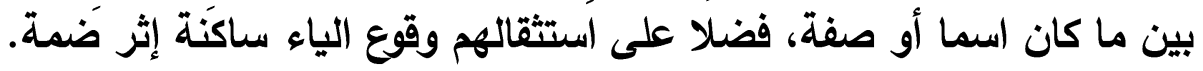

(الآية ج من سورة الصافات.

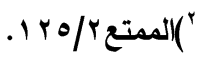
rالآية r r من سورة النجم. 


\section{r - ت تقليم حركة الأصل على التخفيف أو المكس}

من ذلك مـا ذكره أبو الحسن من إدغام المضعف الذي سكن آخره:" والذين من

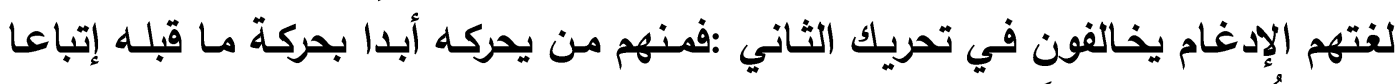

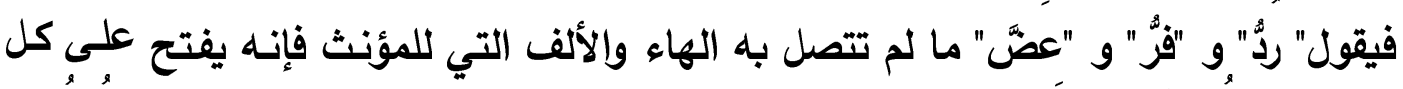

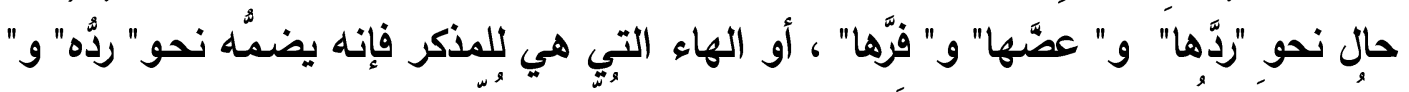

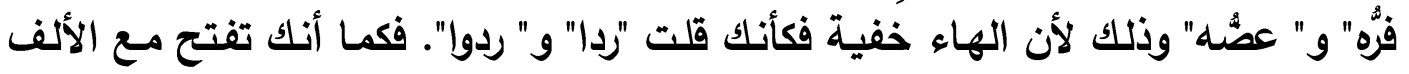

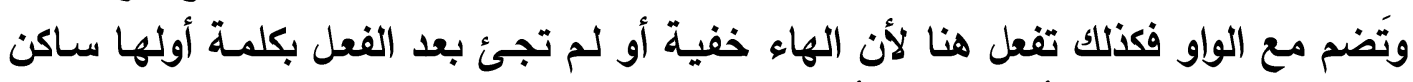

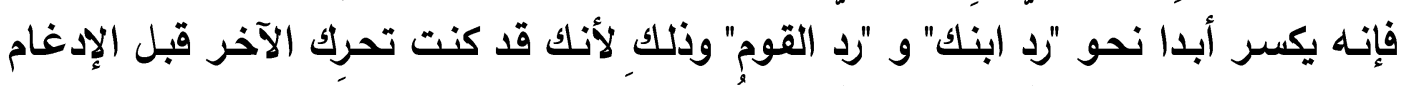

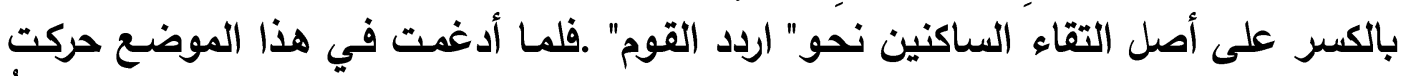

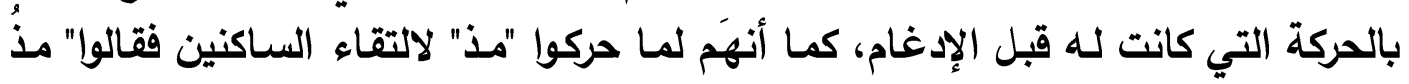

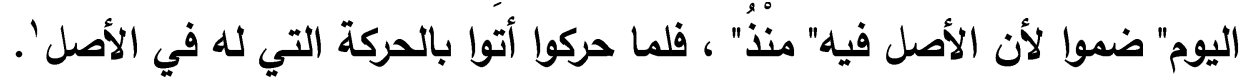

ومنهم من يفتح على كل حال إلا إذا كان بعده ساكن وذلك لأنه آثر التخفيف واعتد

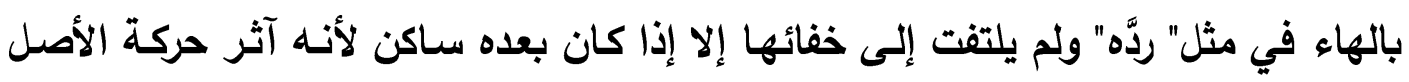

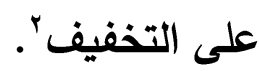

ومـنهم مـن يفتح على كل حسال-كـان بعده سـاكن أو لـم يكن - وذلكـ لأنسه آثر

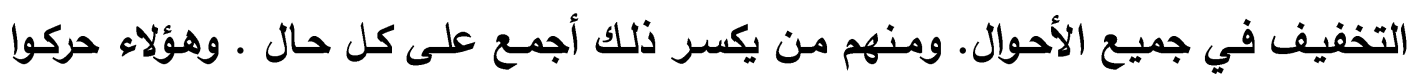
بالحركة التي هي لالتقاء الساكنين في الأصل.

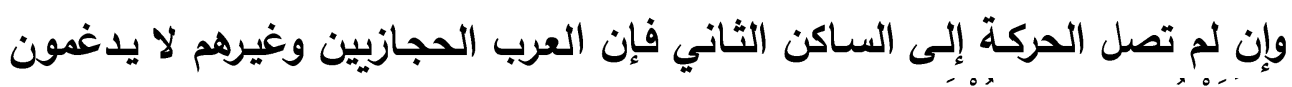

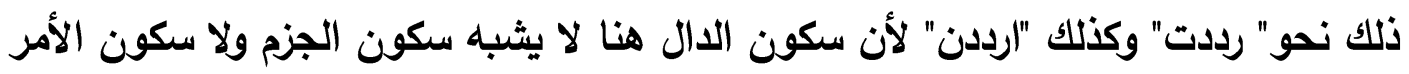

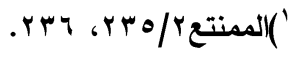

$$
\begin{aligned}
& \text { " }
\end{aligned}
$$

(حولية كلية الآداب- جامعة بني سويف عدد خاص - يناير (.r.Y) 
والنهي، وإن كان "ارددنَ" أمراً لأنها إنما سكّنت من أجل النون كما سكنت من أجل التاء

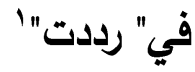

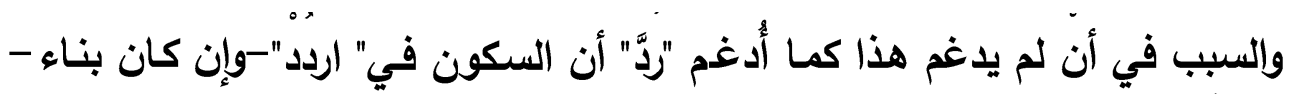

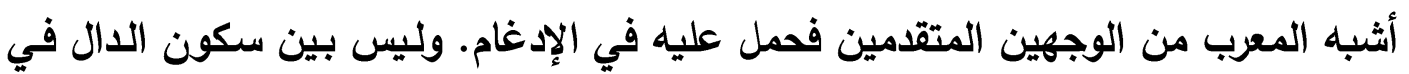

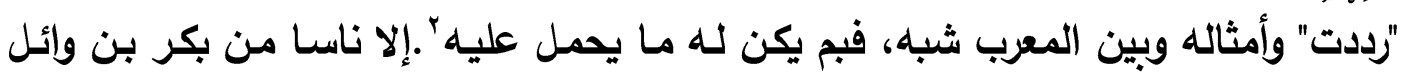

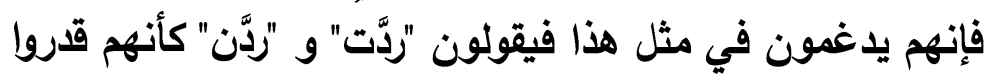

الإدغام قبل دخول النون والتاء. فلما دخلتا أبقوا اللفظ على ما كان عليه قبل دخولههما"؟. ويمكن القول إنه يمتنع الإدغام عند سكون المماثل الثاني لغير الوقف، سواء كان

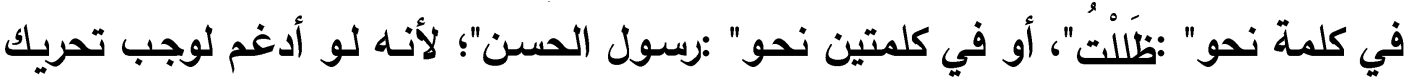

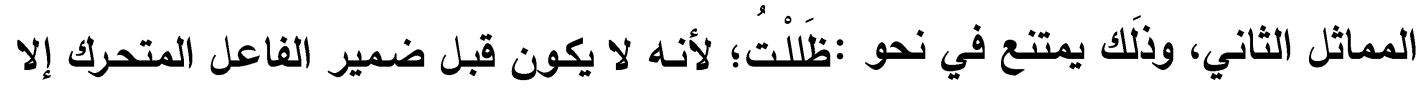

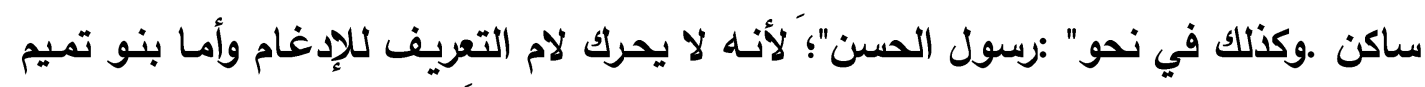

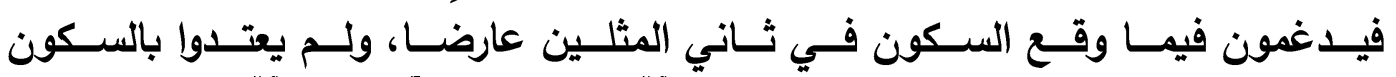

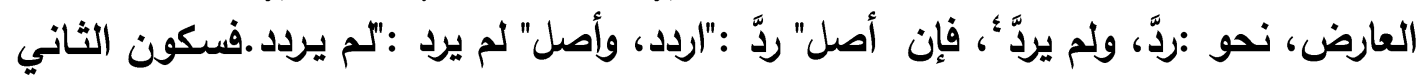

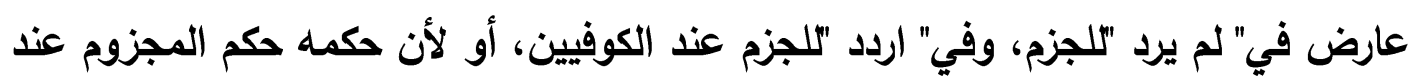
البصريين

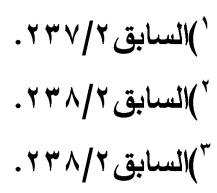

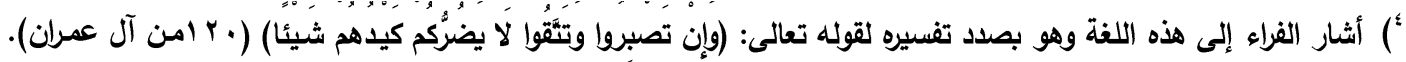

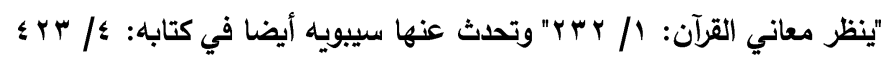


لا يقال :سكوِن اللام فِي" ظللت "عارض، فينبني أن يجوز فيه الإدغام عند بني

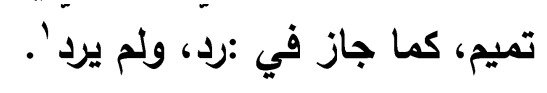

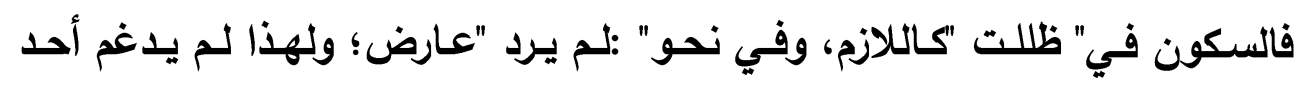

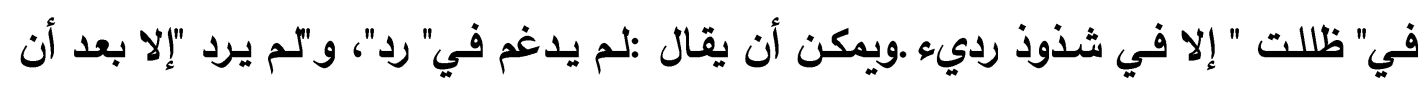

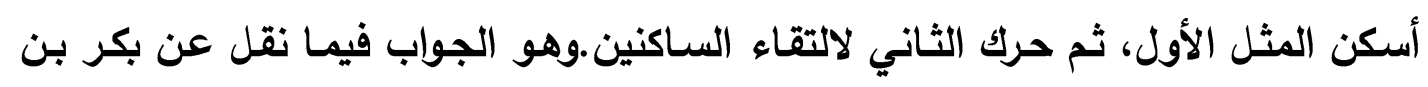

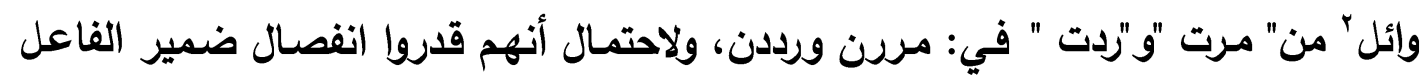

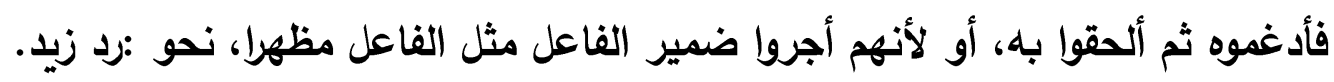

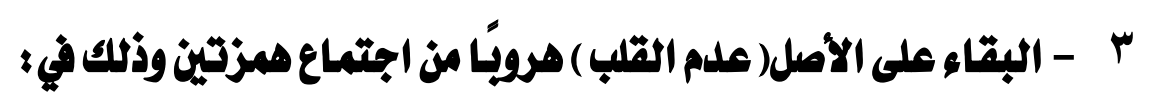

-اسم الفاعل من الثلاثي المجرد الأجوف المهموز اللام

اذا لم يعتل الفعل لم يعتل اسم الفاعل منه، وعلة تصحيح الياء والواو في الفعل أنـه

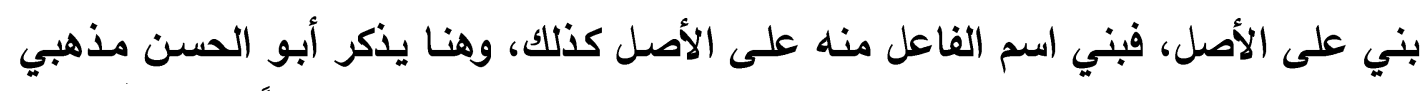

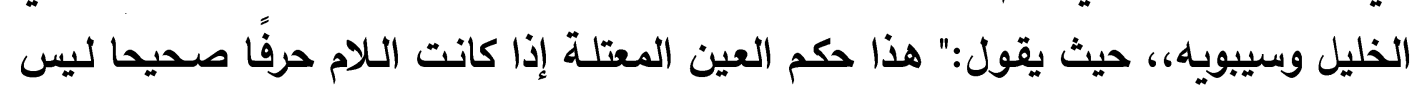

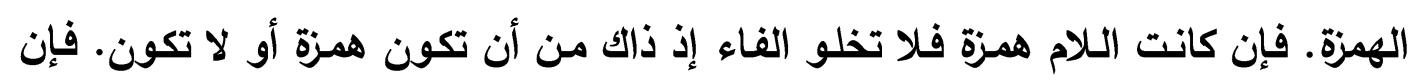

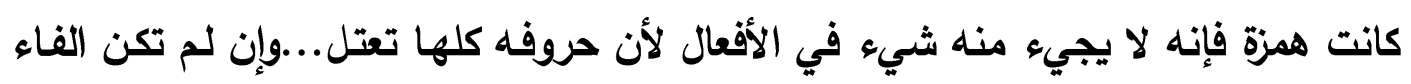

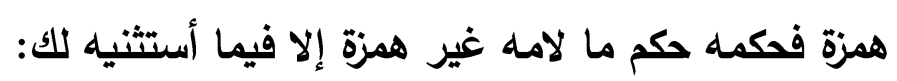

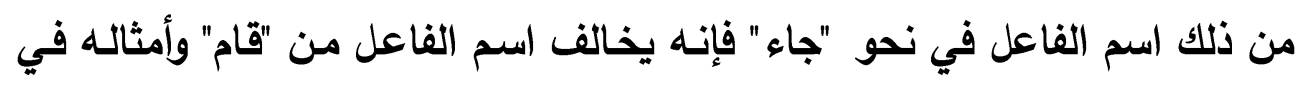

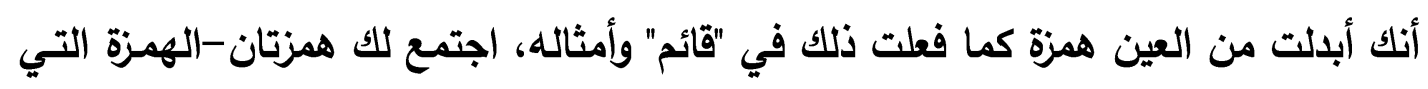

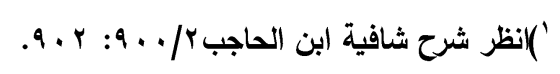

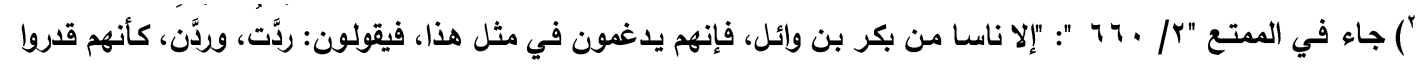

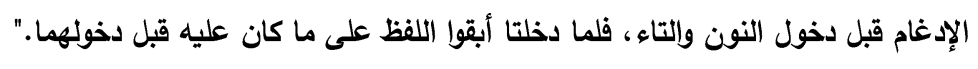

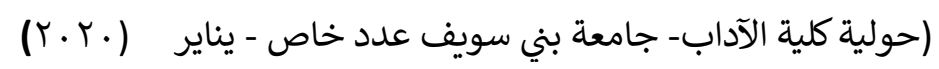




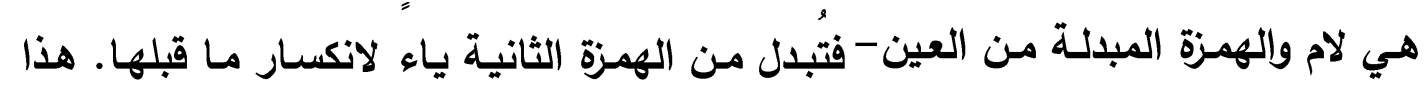

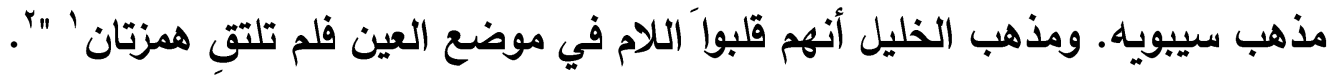
ويمكن القول إن اسـم الفاعل مـن الأجوف المهموز "الـلام"-عند سيبويـه- تقلب لامِه ياءٍ إذا همزت العين لثقل اجتمـاع الهمزتين، فالهمزة الثانية في "جائئي" ونحوه تقلب

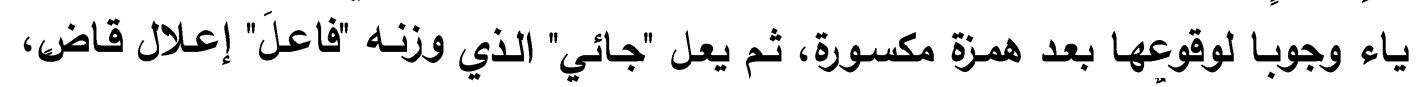
فيصير وزنـه "فاع".

أما الخليل فيرى تقديم اللام على العين كراهية اجتماع الهمزتين فصار "جائي"، فلو

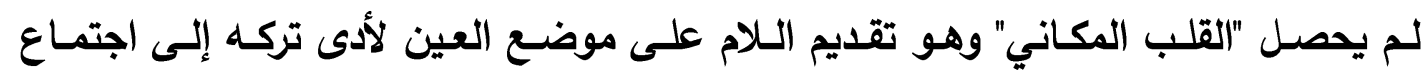

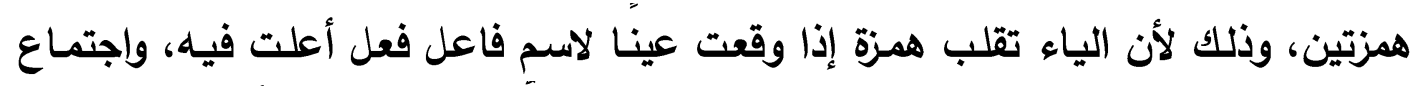

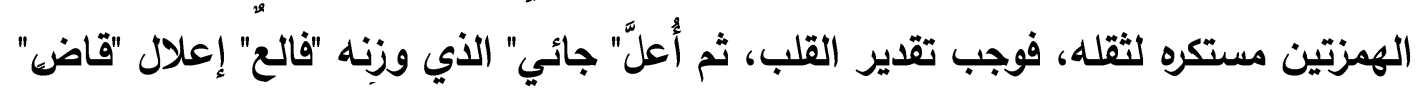

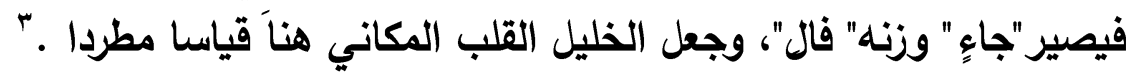
واختار ابن عصفور رأي سييويـه مـع عدم إجراء القلب المكاني الذي هو خـلاف الأصل.

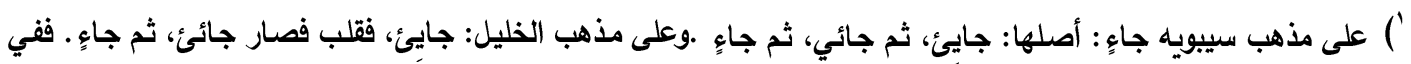

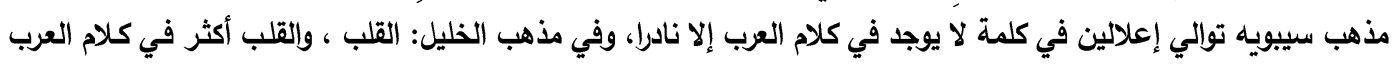
من توالي الإعلالين على الكلمة. (

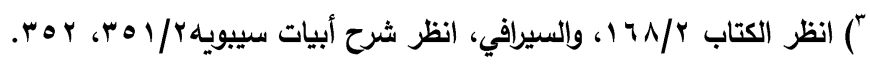




\section{تقائج البهش:}

يخلص الباحث من دراسته في هذا البحث إلى النتائج التالية:

1- ترتبط قواعد العلة بالأصول الصرفية لأنها داخلة في القياس وأركانه من فرع وأصل، وداخلة على السماع ، واستصحاب الحال.

ץ- ما هو موجود في المتع في التصريف ليس كله لابن عصفور ، ولا كله للنحاة، بل هو متعلق بالاستـلال من الارجة الأولى لذا لا نسلم به كله، وذلك حسب توظيف تلك القواعد ومدى ارتباطها بالعة الصرفية. r- ابن عصفور ذو منهج خـاص في كتابه وتفكيره، تبرز فيـه شـمول نظرتـه، ودقـة ملاحظته، وجدة تصـوره، وابتكاره وتوسعه في التعليل ، وفي القياس حيث إنـه يتميز بالمنهج العلمي التقريبي في عرض العلل، مع التنظيم والتترتيب، في عبارة مشرقة، وأسلوب جذاب يخفف من جفاف الصرف، مع الإكثار من الثواهد والأمثلة. ؟ - لـ يلتزم مذهب البصرة أو الكوفـة أو بغداد، إنما اتبع منهج المحققين من العلمـاء معتمدا على الاختيار المدعوم بالايليل ؛لذا كان موقفه من علماء التصريف موقف المختار المميز الذي لا يرتبط بآثارهم إلا في حدود مـا يلائم منهجه بلايليل أنه أخذ عن البصريين وخالفهم ، وكذلك كان موقفه من الكوفيين والبغداديين، وإن كانت مخالفته للكوفيين أوسع. ه- في موقفه من البصريين والكوفيين والبغداديين لا يتخطى القرن الرابع، إذ يقف من البصريين عند ابن جني، ومن الكوفيين عند ثعلب، ومن البغداديين عند القالي. أما من 
خلف بعد هؤلاء من علماء تلك المدارس الثلاث فلا ترى له في الممتع أخذًا عنهم وموافقة لهم أو مخالفة.

צ- اعتماده الجدل والاحتجاج حتى يستوفي جميع جوانب الموضوع، فربما يعرض للمسألة الواحدة مذهبين، ويحتج لكل منهما، ثم يرجح أحدهما على الآخر بحجاجه المنطقي اللغوي، منثورا في طياته فيض من ألوان السماع والقياس. - V - مع تمسكه بالنهج البصري ،فقد كان مستقلَّ ،يرفض العصبية المذهبية، ويختار من آراء الكوفيين وغيرهم كان يقتنع بصوابه، ويخرج على إجماع المدرستين في بعض الأحيان. 1- كانت لله آراء كثيرة وتعليلات وتحليلات لم يسبق إليها. 9 - أما أسلوبه في معالجة العلل فيجمع بين الوضوح والبساطة تارة والغموض والاقتضاب تارة أخرى، مما دفعني لمتابعة المـادة العلمية في مظانها لأشبعها درسـا وتمحيصا لفك مـا استغلق وإيضاح ما أبههم، ومع هذا فقد امتاز بالحرص على التيسير في الصرف العربي بما صنعه في كتابه(الممتع في التصريف)؛بايجازه في العرض، ووضوح في التعبير ، واختصـار في العناوين، وبعد عن الخلافات التي لا جدوى من ورائها. ـ 1 - تـأثره بسـابقيه مـن حيث أصـول الصـناعة وأدلتهـا، ومـن حيـث المـادة العلميـة ، وشواهده وأبوابه وتعريفاته.

11 - ترك أثرا واضحا في كل من جاء بعده من الصرفيين وطبعهم بطابعه ، فأخذوا عنـه آراءه وتعليلاته وتحليلاته وأقيسته وبعض تعريفاته وأسماء أبوابه وعناوينه المختصرة. 


\section{توصياث البحث:}

1- العمل على تعقب المزيد من العلل الصرفية ودراستها دراسة صوتية حديثة. r- عمل دراسة عن الجوانب التعليمية في الفكر الصرفي التطبيقي. وفي الختام آمل أن أكون قد وقُقِتُ فيما اجتهدت فيه قدر طاقتي.... والحمد لله أولاً وآخرا، 


\section{تائمة المراجع والمبادر}

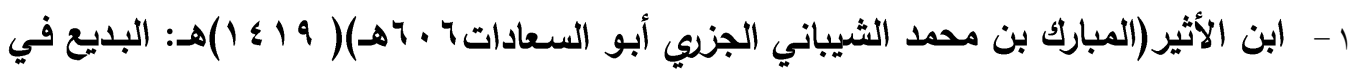
علم العربية تحقيق ودراسة د. صالح حسين العايد، ط. أولى ،جامعة أم القرى. r - الأخفش: معاني القرآن تحقيق د. عبد الأمير محمود الورد ط. أولى، بيروت. r- الأثموني(أبو الحسن نور الدين . .9هـ):( 991 اهـ.) شرح الأشموني على ألفية ابن مالك، قدم له ووضع هوامشهه وفهارسـه حسن حمد ،إشراف إميل بلديع يعقوب، بيرون، لبنان،منشورات محمد علي بيضون ،دار الكتب العلمية.

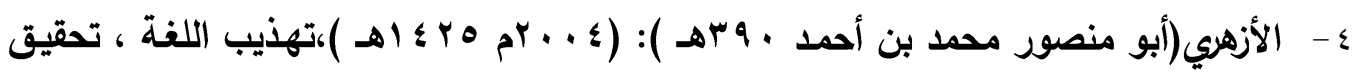
د. أحمد مخيمر، ط. أولى، ، دار الكتب العلمية بيروت لبنان منشورات محمد علي بيضون.

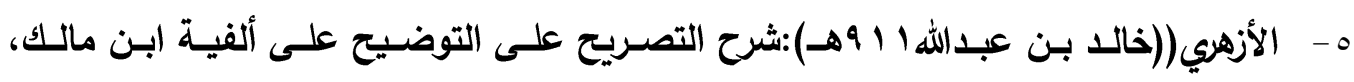
وبهامشه حاشية الثيخ يس العلمي، دار الفكر •

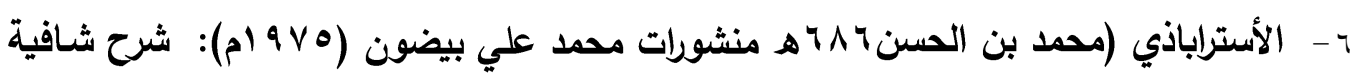
ابـن الحاجب مـع شـرح شـواهده لعبدالقادر البغدادي، حققها وضبط غريبها محمد نـور الحسن وآخرين، دار الكتب العلمية، بيروت، لبنان .

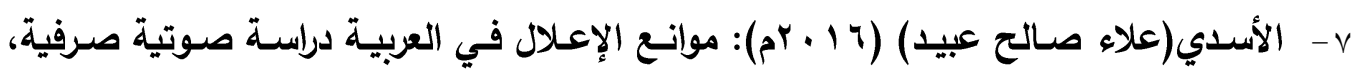
عمان، الأردن، الرضوان للنشر والتوزيع. ^- استيتية (د. سمير شريف): (r ا + r م): علم الأصوات النحوي ومقولات التكامل بين الأصوات والنحو والدلالة ، ط. أولى، دار وائل للنشر. 


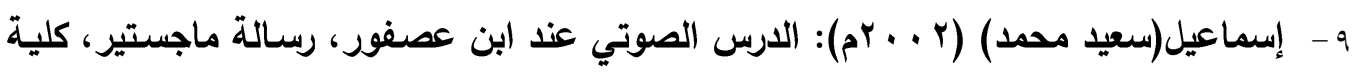
الاراسات العليا، جامعة النجاح • 1 - إسماعيل(د. شهاب النمر) (7 1 • rم):علم التصريف دراسة في فكر ابن جني ، ط. أولى، ،دار

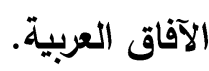

1, الأثموني: شرح الأثموني على ألفية ابن مالك للأشموني، القاهرة مكتبة النهضة المصرية.

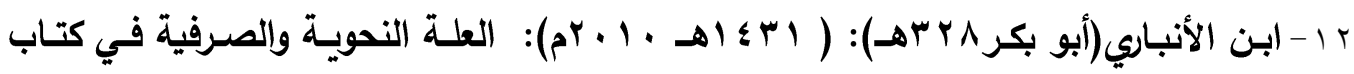
إيضاح الوقف والابتداء في كتاب الله، د. عبد الحميد شحاذة، و د.صبيحة طعيس، الجامعة

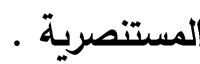
r I - ابن الأنباري(أبو البركات عبدالرحمن بن محمد Iه VA): - (9 V ام): الإنصـاف في مسائل الخـلاف بين النحويين البصريين والكوفيين ، تحقيق محمد محي الدين، دار الفكر. -أسـرار العربيـة تحقيق د.محمد بهجـة البيطار،ط ا، دمثق،سوريا، مطبوعـات المجمـع العلمي العزبي. ع أ-أنيس(د. إبراهيم):

- (99 (9) :الأصوات اللفوية ، مكتبة الأنجلو المصرية. - (991 (م)): دلالة الألفاظ ، الأنجلو المصرية. - (999 (م)): اللهجات العربية ، القاهرة، مكتبة الأنجلو المصرية. - (99 (9) (1): من أسرار اللغة ، مكتبة الأنجلو المصرية . 1 -أيوب(د. عبدالرحمن(؟ ؟ 9 ام): التطور اللغوي ، ط القاهرة. 
1 ا -برجشتراسر (؟9 9 (1)): التطور النحوي للغة العربية، أخرجه وصححه وعلق عليه د. رمضان عبدالتواب، ط.r، القاهرة،مكتبة الخانجي. IV

- التفكير اللغوي بين القديم والجديد ، ط. مكتبة الثباب. - (.... -

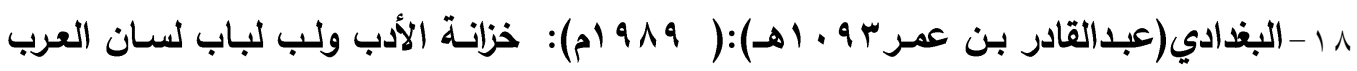
تحقيق عبد السلام هارون، ط. r، مكتبة الخانجي · 9 1 -بكر(د.محمد صلاح الدين)، ( 1991 (1)) قضية الأصالة والفرعية في دراسـة النحو العربي، دار النطاقين للطباعة والنشر والتوزيع ·

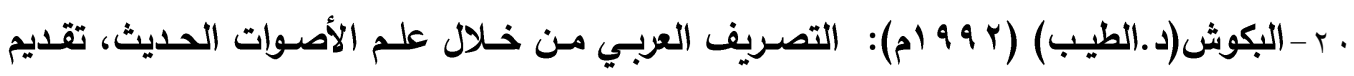
صالح القرمادي، طن.

ا ( - البنا (V • \& ()): اتحاف فضلاء البشر بالقراءات الأربعة عشر، ط. ا، بيروت، عالم الكتب.

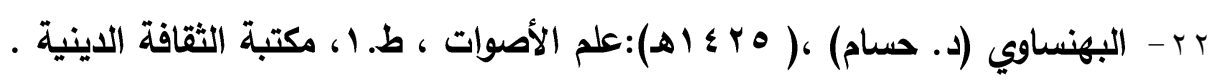

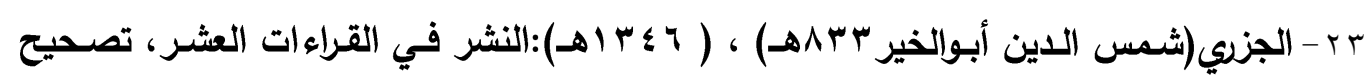
محمد أحمد دهمان، مطبعة التوفيق،دمثق.

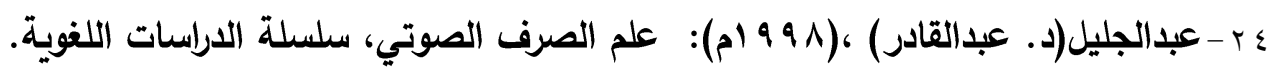
هץ-الجندي(د. أحمد علم الدين) ،( rی19 ام)،: اللهجات العربية في التراث الدار العربية للكتاب .

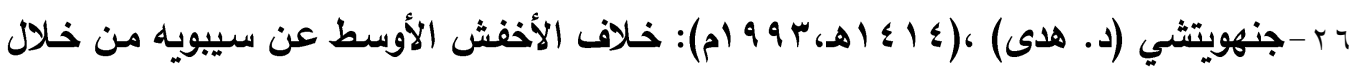
شروح الكتاب حتى نهاية القرن الرابع الهجري ط. أولى .

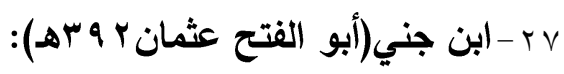




\section{د. حسن رمادي غانم نصر}

-التصريف الملوكي تحقيق د. ديزيرة سقال، بيروت دار الفكر العربي. -الخصائص تحقيق محمد علي النجار، بيروت، دار الهاى.

- سـر صـناعة الإعراب تحقيق د. محمد حسن إسـماعيل وآخرين، ط. ؛، ،دار الكتب العلميـة، بيروت ، منشورات محمد علي بيضون.

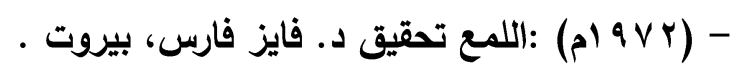
- المحتسب في تبيين وجوه شواذ القراءات والإيضاح عنها تحقيق علي النجدي ناصف وآخرون، لجنة إحياء التراث.

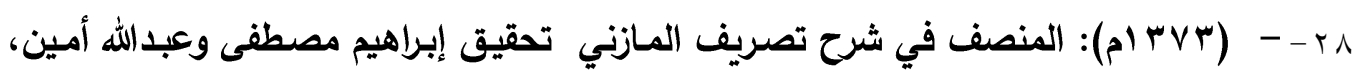
،ط. ا، دار إحياء التراث القديم، مصطفى البابي الحلبي · 9 - (900 19 ام): جواد(د.مصطفى):المباحث اللفوية في العراق ، القاهرة .

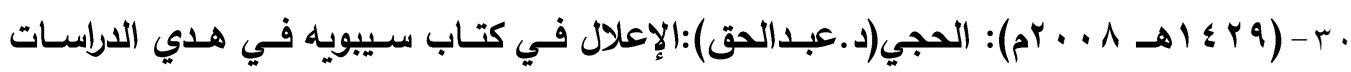
الصوتية الحديثة ، ط. ا، العراق،مركز البحوث والدراسات الإسلامية.

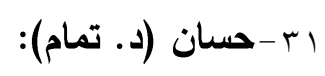

- ( . . . rم): الأصول دراسة إبستيمولوجية للفكر اللغوي عند العرب، طا، الهيئة العامة للكتاب. - (ب9 9 ام): البيـان في روائسع القرآن دراسـة لفويـة وأسـلوبية لنص القرآن ، ط. القـاهرة، عـالم الاكتب.

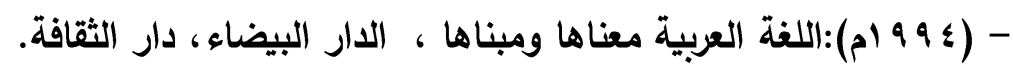
- (1991) -

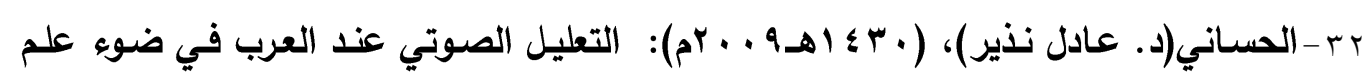
الصوت الحديث قراءة في كتاب سيبويه ،ط. ا، بغداد، مركز البحوث والدراسات الإسلامية. 
rr الحسـن بن قاسم المـرادي :الجنى الداني في حروف المعـاني، تحقيق سـعيد الأففاني، ط. ثانية. كبيروت ، مؤسسة الرسالة.

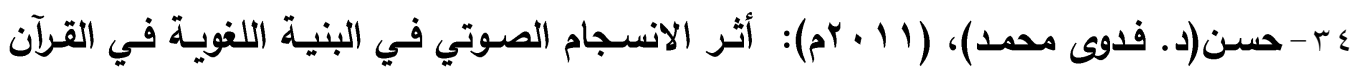
الكريم ، إربا الأردن ، عالم الكتب الحديث. مب- الحديثي(د. خديجة) ، ( 91 (م): دراسات في كتاب سيبويه، الكويت، وكالة المطبوعات. بr-أبو حيان الأندلسي(أثير الاين محمد بن يوسفه ؛ Vه): - (9 (9 ام): ارتثاف الضرب من لسان العرب، تحقيق وجمع ودراسة د. رجب عثمان، مراجعة د. رمضان عبدالتواب، القاهرة، مكتبة الخانجي. - (1 . . rم): البحر المحيط ، دراسة وتحقيق وتعليق: الثيخ عادل أحمد عبد الموجود وآخرين، ، بيروت ، لبنان، منشورات محمد علي بيضون ، دار الكتب العلمية. V V-حمـودة(د. طـاهر سـليمان) ، (r 99 ( 19 م):القيـاس فـي الـارس اللغوي: بحث في المـنهج، الإسكندرية،الدار الجامعية.

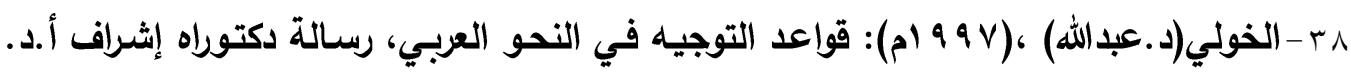
محمد عبداللطيف حماسة، كلية دار العلوم جامعة القاهرة 9 - الداني(أبو عمرو):التيسير في القراءات السبع تصحيح أوتوبرتزل، مطبعة استانبول. • ـ - الراجحي (د. عبده) ، (9VV) ام):النحو العربي والدرس الحديث ، الإسكندرية،دار الثقافة. اء - الزجاج(أبو إسحاق إبراهيم ين محمد | اس هـ): إعراب القرآن المنسوب تحقيق إبراهيم الأبياري ط. ثالثة بيروت. - ط. - ط

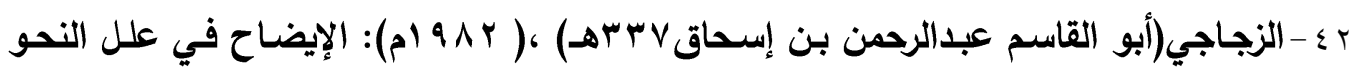
تحقيق د. مازن المبارك ط. رابعة، بيروت . 


\section{د. حسن رمادي غانم نصر}

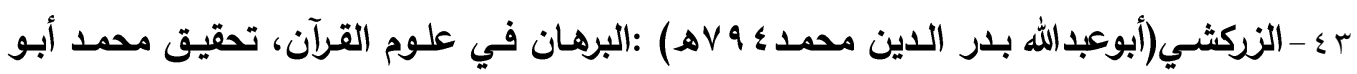
الفضل إبراهيم، ط. ا،دار إحياء الكتب العربية، عيسى البابي الحلبي.

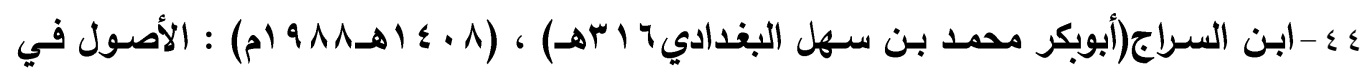
النحو، تحقيق عبدالحسين الفتلي، طسبيروت،مؤسسة الرسالة. ه - سقال(د.دزيرة) ،(797 99 (1): الصرف وعلم الأصوات، بيروت،دار الصداقة العربية .

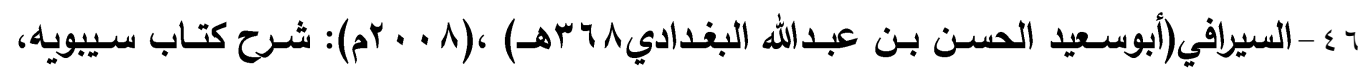
تحقيق أحمد حسن مهذلي، و علي سيد علي، بيروت، لبنان،دار الكتب العلمية. V ₹ - سييويهـ( • 1 ا هـ): الكتاب تحقيق عبدالسلام هارون،ط. ا، بيروت،دار الجيل. ^ـ - السيوطي(عبدالرحمن بن أبي بكر 11 11 هـ): - (آ (1/م): المزهر في علوم اللغة تعليق محمد جاد المولى وآخرون، بيروت . - همع الهوامع في شرح جمع الجوامع تحقيق أحمد شمس الدين، منشورات محمد علي بيضون، الكويت، دار البحوث العلمية.

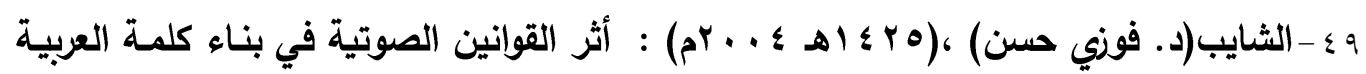
، ط. أولى، إربد، الأردن،عالم الكتب الحديثة.

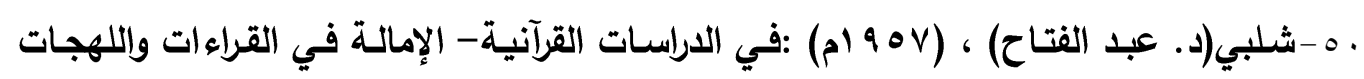
العربية ، مؤسسة المطبوعات الحديثة. ا ه-شواهنة(د. سعيد محمد) ، V) . . rم): القواعد الصرف صوتية بين القدماء والمحدثين، عمان،

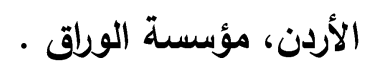

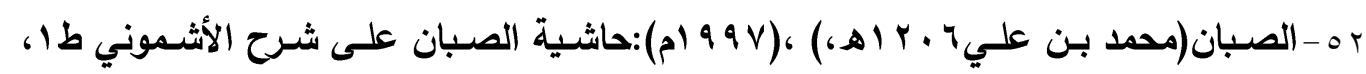
ضبط وتصحيح إبراهيم شمس الدين، بيروت، دار الكتب العلمية. 


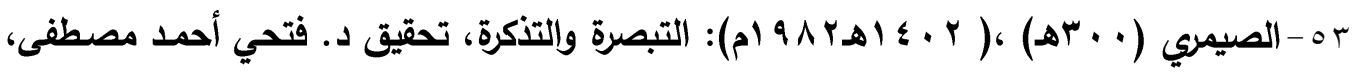
دمثق، دار الفكر. ـ - الطبري (محمد بن جريز • اسهـ):جامع البيان عن تأويل آي القرآن تحقيق محمود محمد شاكر دار المعارف مصر، والمطبعة الأميرية. 0ـ - عباس حسن :النحو الوافي ط ب ا القاهرة ،دار المعارف. 4ه - عبدالفتاح الحموز ، (هی 9 (م): الحمل على الجوار في القرآن الكريم، الرياض، مكتبة الرشد.

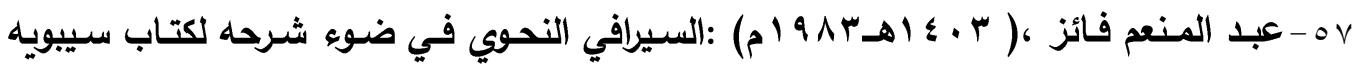
دراسة وتحقيق عبد المنعم فائز، ط. أولى ،دار الفكر.

$$
\text { 1 - مه - عبدالتواب (د. رمضان): }
$$

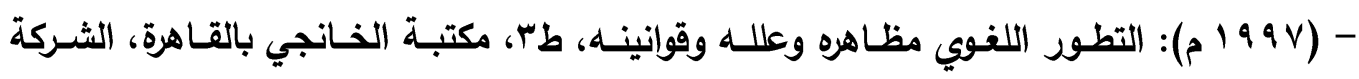
الدولية للطباعة. - _ _99 19م):فصول في فقه اللغة ، القاهرة،الخانجي.

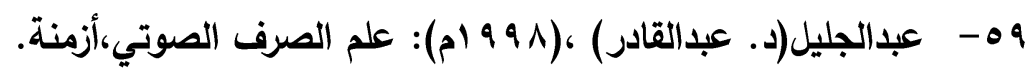
• ؟ - عرار(د. مهدي أسعد) ،(r . . rم): ظاهرة اللبس في العربية جدل التواصل والتفاصل، عمان، الأردن،دار وائل للنشر والتوزيع. آ- عبدالعزيز(د. محمد حسن) ،(9909 ام): القياس في اللفة،طا، القاهرة،دار الفكر العربي.

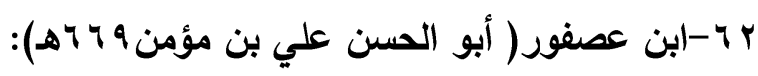
- (،191م): شرح جمل الزجاجي، تحقيق د. صاحب أبو جناح، بغداد.

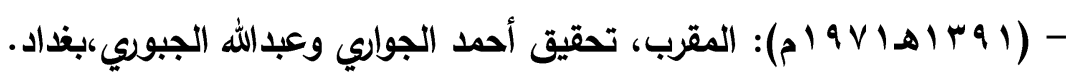

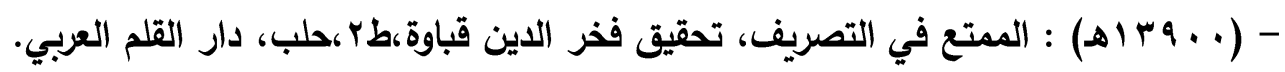




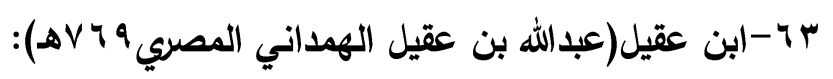
- شرح ابن عقيل على ألفية ابن مالك تحقيق محمد محيي الدين عبد الحميد، القاهرة، ط • ب دار التراث. - (1 . . rم): المساعد على تسهيل الفوائد، تحقيق وتعليق د. محمد كامل بركات، مكة المكرمـة، جامعة أم القرى.

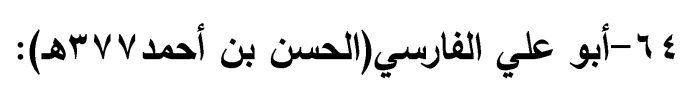

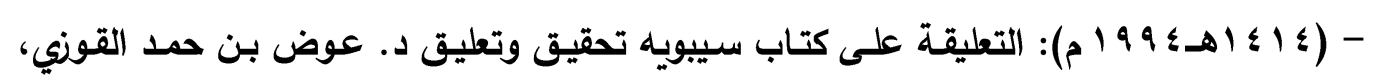
ط.1، الرياض، جامعة الملك سعود.

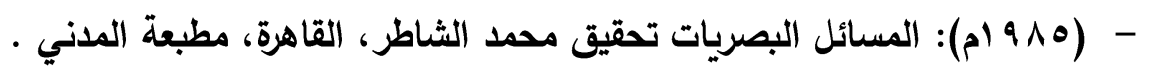
- - 19 - (م) المسائل الحلبيات تحقيق حسن هنداوي ،ط. أولى ، دمثق، دار العلم. -(49 (99): عفيفي(د. أحمد): ظاهرة التخفيف في النحو العربي،طا، الدار المصرية اللبنانية.

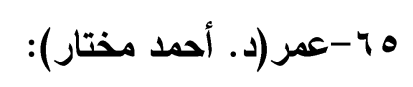
- (991) - البحث اللغوي عند العرب ، عالم الكتب . - (99v) צ - العنبكي (د.علي عبدالله حسين):

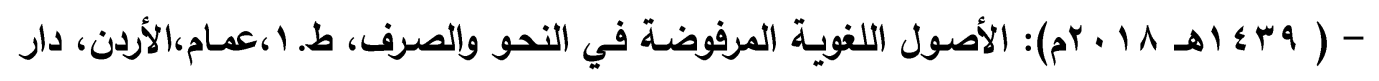
الرضوان.

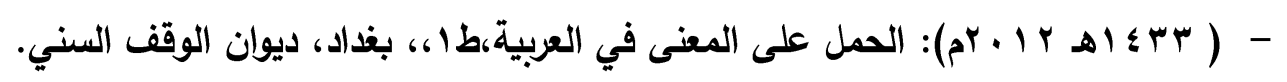

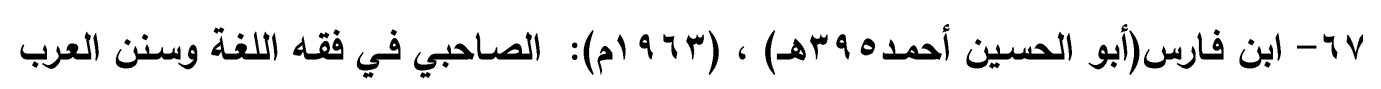
في كلامها، تحقيق: مصطفى الثويمي، بيروت ،مؤسسة بدران للطباعة والنشر. 


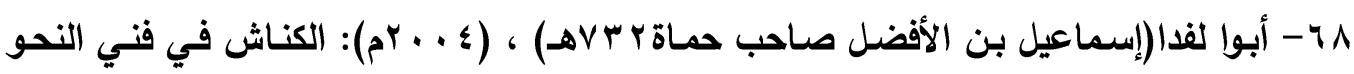
والصرف ، دراسة وتحقيق د. رياض الخوام، بيروت، المكتبة العصرية.

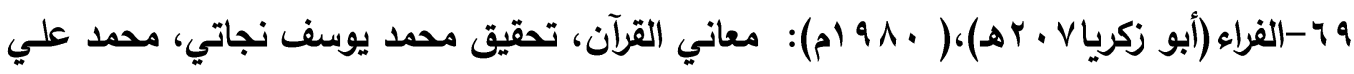
النجار، القاهرة،الهيئة المصرية العامة للكتاب. • . ل القاضي(عبدالفتاح) :القراءات الثاذة دار إحياء الكتب العربية. الV- قبـاوة (د. فنـر الـــين): ابـن عصـفور والتصــريف، منشــورات دار الآفـاق الجديــةة،

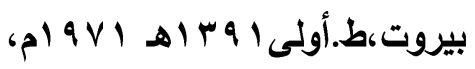
: V T

- -

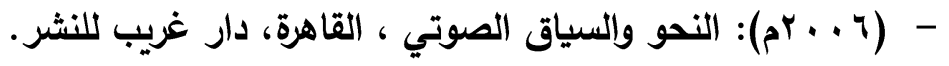

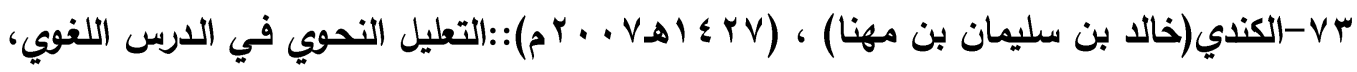
ط. ا، عمان، الأردن، دار المسيرة للنشر والتوزيع.

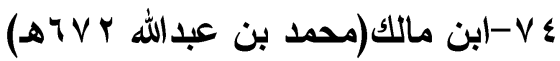
- (99 (1 م): شرح التسهيل لابن مالك تحقيق د. عبد الرحمن السيد، ود. محمد بـوي المختون، ط. أولى القاهرة . - ( ) ( ام): شرح الكافية الثافية تحقيق عبدالمنعم هريدي ط. أولى دمثق .

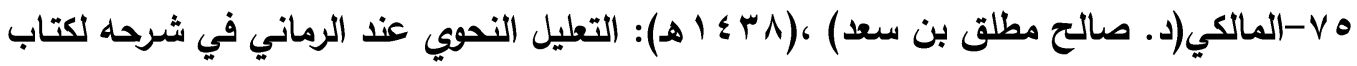
سيبويه دراسة وصفية تحليلية، رسالة دكتوراه، المدينة المنورة، الجامعة الإسلامية .

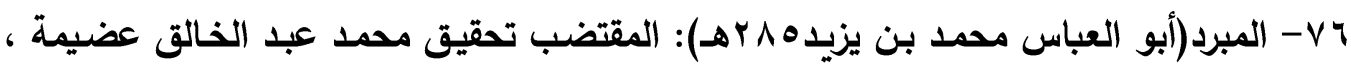
بيروت عالم الكتب. 


\section{د. حسن رمادي غانم نصر}

- VV تطبيقية في سيمانطيقا السرد ، ط. ا، بيروت لبنان.

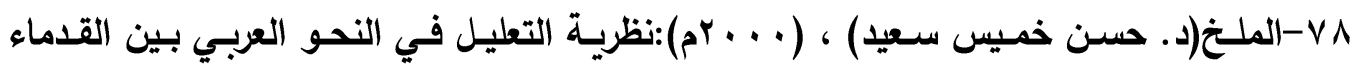
والمحثثين ،عمان ،الأردن، دار الثروق.

9q ابن منظور :لسـان العرب ،تصحيح أمين محمد عبد الوهـاب، ومحمد الصـادق العبيدي، بيروت، لبنان، دار إحياء التراث العربي، مؤسسة التاريخ العربي، • ^-الناصـر(د. عبد المـنعم ) ، (9V1 ام): شـرح صـوتيات سـيبويه دراسـة حديثـة في النظـام الصوتي للعزبية من خلال نصوص كتاب سيبويه ، ط. أولى بيروت لبنان ، دار الكتب العلمية.

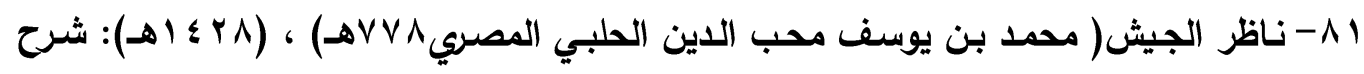
التسـهيل المســى" تمهيد القواعد بشـرح تسـهيل الفوائـد" ، دراسـة وتحقيق د. علـي محمـ فـاخر وآخرين، ط. ا، القاهرة، دار السلام للطباعة والنشر والتوزيع والترجمة.

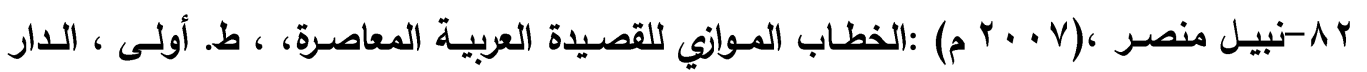
البضاء، دار توبقال للنشر. r r-ندا(د. عصدام) ، ( . . rم): قواعد التوجيه في الصرف العربي، رسالة دكتوراه إثراف أ. د. وفاء كامل، كلية دار العلوم جامعة الفيوم.

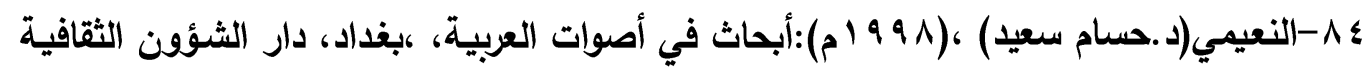
العامة. هـ- النيسـابوري (أبوالفضل): مجمع الأمثال تحقيق محمد أبو الفضل إبراهيم، المكتبة التجاريـة الكبرى بمصر.

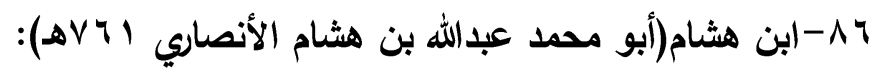


-أوضح المسالك إلى ألفية ابن مالك، ومعه كتاب عدة السـالك إلى تحقيق أوضـح المسالك لمحمد محيي الدين، بيروت، منشورات المكتبة العصرية. -مغني اللبيب تحقيق مازن المبارك ومحمد على الحمد الله ط ب بيروت، دار الفكر العزبي.

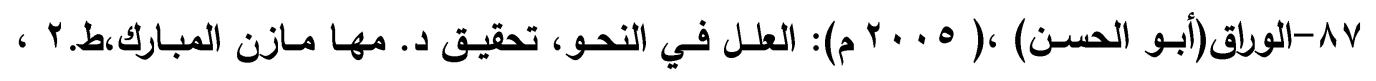
دمثق، سوريا، دار الفكر.

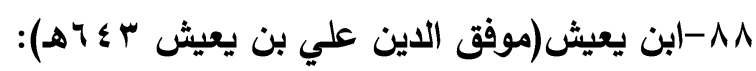
- شرح المفصل بيروت عالم الكتب.

- (91^ ام): شرح الملوكي في التصريف، تحقيق فخر الدين قباوة، ط.ب، الدوحة،دار الأوزاعي. 


\title{
Annual of the Faculty of Arts
}

\author{
A Refereed Academic Annual
}

Published by

the Faculty of Arts - Beni Suef University

\section{Special issue}

January 2020 